Prepared in cooperation with the Somerset County Conservation District

\title{
Water Quality and Quantity and Simulated Surface-Water and Groundwater Flow in the Laurel Hill Creek Basin, Southwestern Pennsylvania, 1991-2007
}

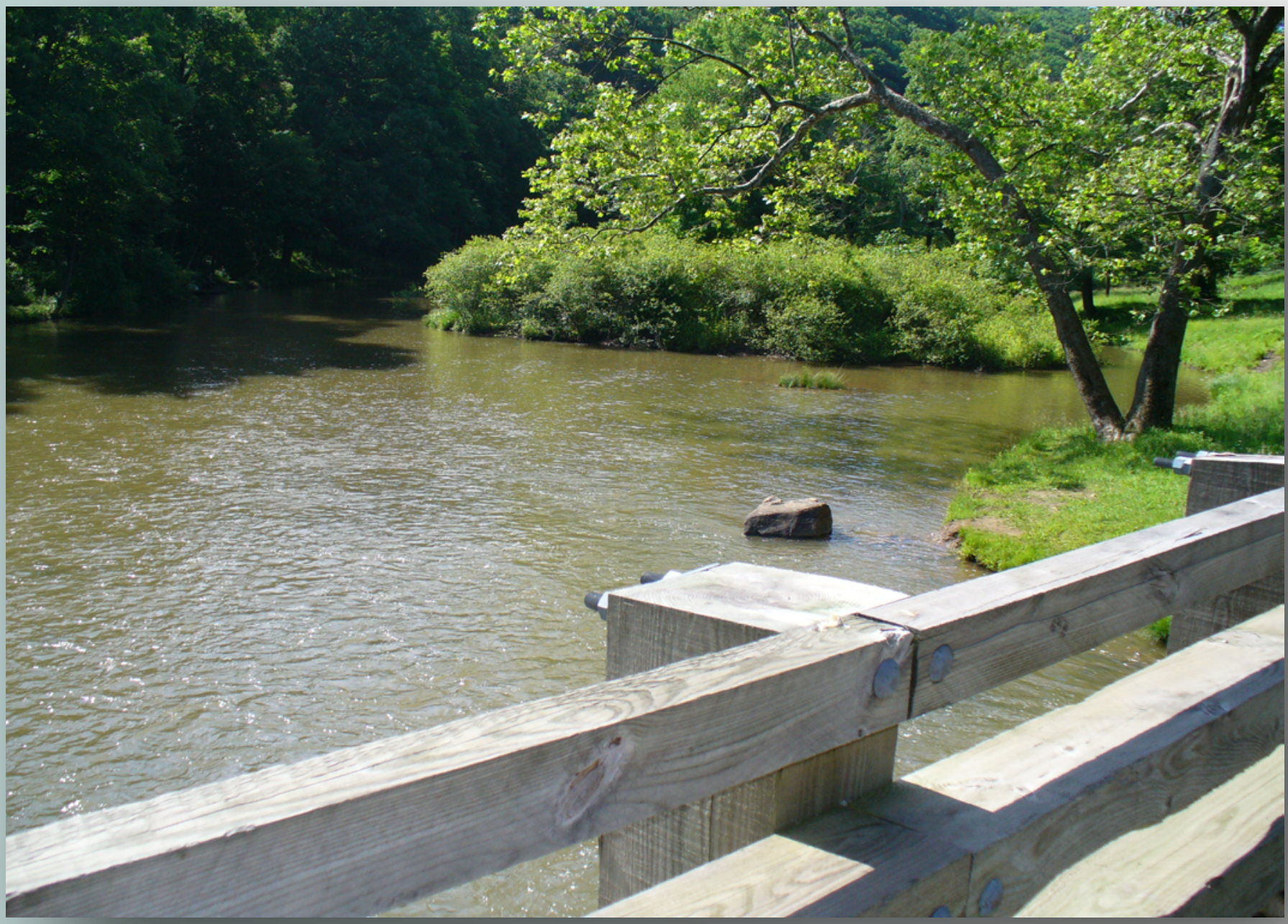

Scientific Investigations Report 2016-5082

U.S. Department of the Interior

U.S. Geological Survey 
Cover: Photo of Laurel Hill Creek as it enters into Laurel Hill Lake at Laurel Hill State Park, Pennsylvania, photo taken on June 22, 2009. (Photograph provided by Daniel Galeone, U.S. Geological Survey) 


\section{Water Quality and Quantity and Simulated Surface-Water and Groundwater Flow in the Laurel Hill Creek Basin, Southwestern Pennsylvania, 1991-2007}

By Daniel G. Galeone, Dennis W. Risser, Lee W. Eicholtz, and Scott A. Hoffman

Prepared in cooperation with the Somerset

County Conservation District

Scientific Investigations Report 2016-5082 


\title{
U.S. Department of the Interior \\ RYAN K. ZINKE, Secretary
}

\section{U.S. Geological Survey William H. Werkheiser, Acting Director}

\author{
U.S. Geological Survey, Reston, Virginia: 2017
}

For more information on the USGS - the Federal source for science about the Earth, its natural and living resources, natural hazards, and the environment—visit http://www.usgs.gov or call 1-888-ASK-USGS.

For an overview of USGS information products, including maps, imagery, and publications, visit http://store.usgs.gov.

Any use of trade, firm, or product names is for descriptive purposes only and does not imply endorsement by the U.S. Government.

Although this information product, for the most part, is in the public domain, it also may contain copyrighted materials as noted in the text. Permission to reproduce copyrighted items must be secured from the copyright owner.

Suggested citation:

Galeone, D.G., Risser, D.W., Eicholtz, L.W., and Hoffman, S.A., 2017, Water quality and quantity and simulated surface-water and groundwater flow in the Laurel Hill Creek Basin, southwestern Pennsylvania, 1991-2007: U.S. Geological Survey Scientific Investigations Report 2016-5082, 85 p., https://doi.org/10.3133/sir20165082.

ISSN 2328-0328 (online) 


\section{Contents}

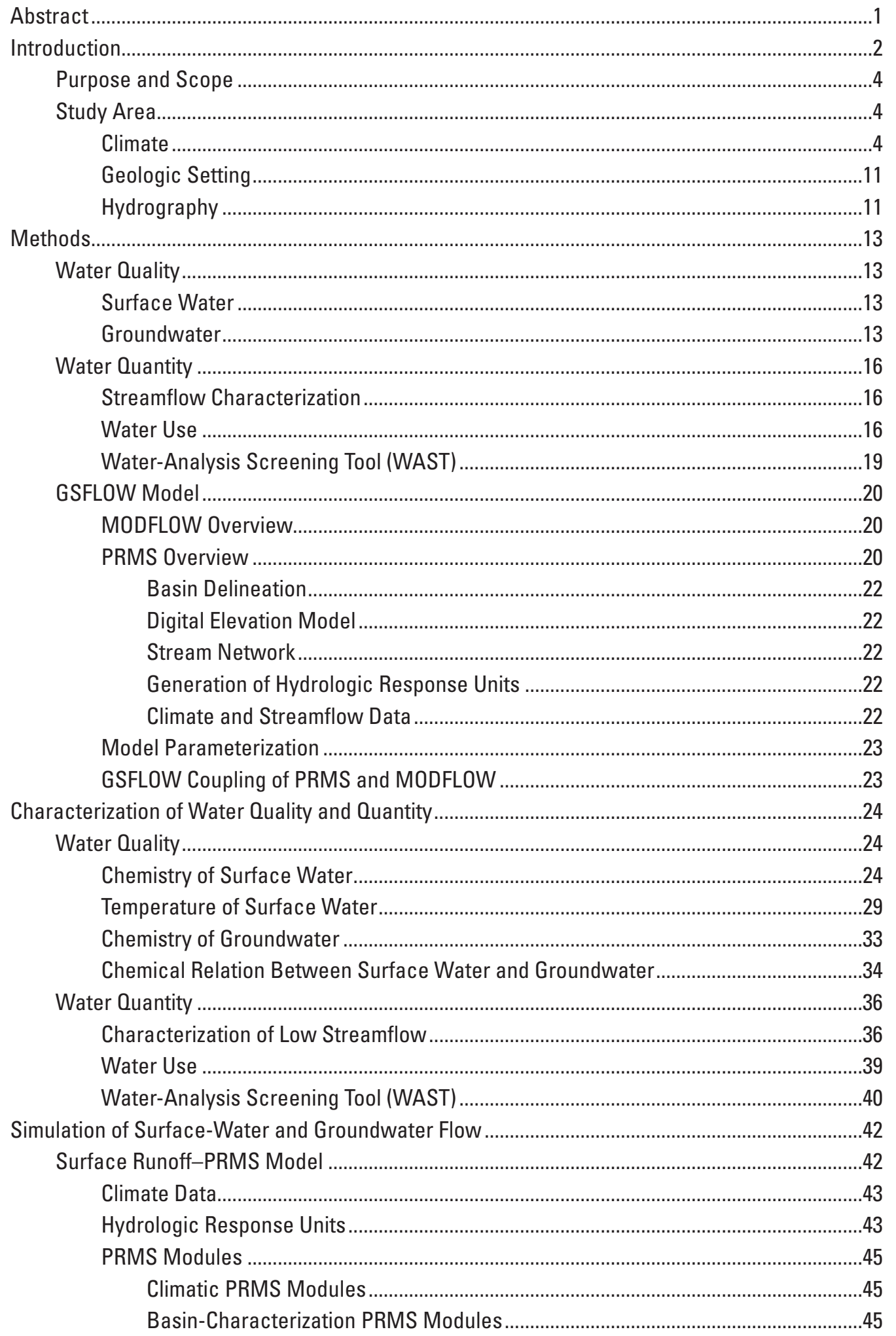


Groundwater - MODFLOW Model......................................................................................

Spatial and Temporal Discretization.......................................................................51

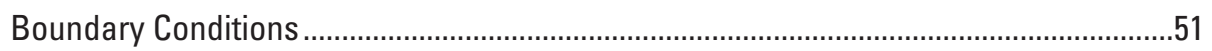

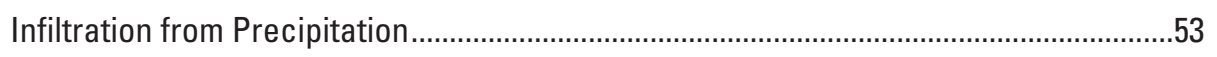

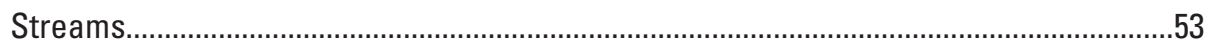

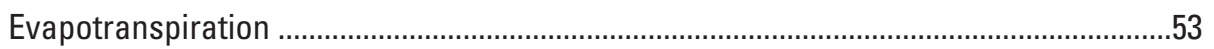

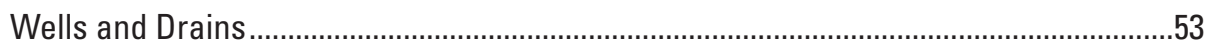

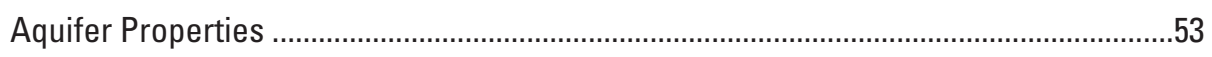

MODFLOW Steady-State Calibration ………..........................................................

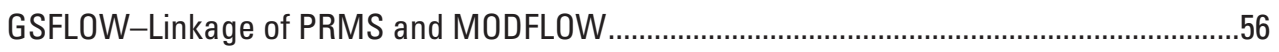

GSFLOW Model Results......................................................................................

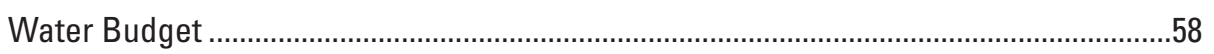

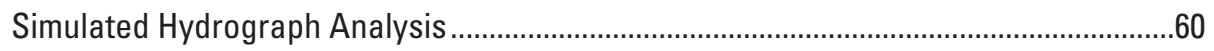

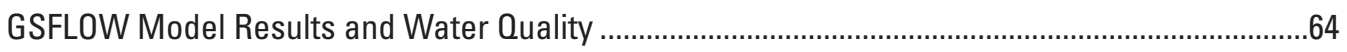

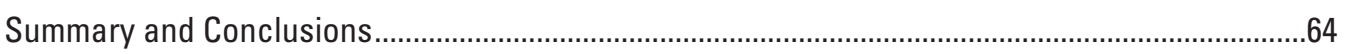

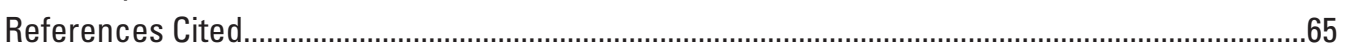

Appendix 1. Concentrations of selected water-quality constituents and values of selected physical characteristics in surface-water samples collected during low-flow conditions in the Laurel Hill Creek Basin, southwestern, Pennsylvania, June and September 2007. (Appendix 1 available online as Excel file at https://doi.org/10.3133/sir20165082)

Appendix 2. Monthly maximum stream temperature criteria established by the Commonwealth of Pennsylvania (2009), and monthly daily maximum, minimum, and mean stream temperatures for five sites along the main stem of Laurel Hill Creek Basin, south-western, Pennsylvania, 2007-10

Appendix 3. Daily mean streamflow values for station 03080000, Laurel Hill Creek at Ursina, Pennsylvania, July 17, 2007, through July 8, 2010

Appendix 4. Concentrations of selected water-quality constituents and values of selected physical characteristics in groundwater samples collected in the Laurel Hill Creek Basin, southwestern, Pennsylvania, summer and fall 2007. (Appendix 4 available online as Excel file at https://doi.org/10.3133/sir20165082)

\section{Figures}

1. Map showing Laurel Hill Creek Basin, southwestern, Pennsylvania ................................5

2. Map showing topographic elevations in Laurel Hill Creek Basin, southwestern, Pennsylvania

3. Map showing Land use and land cover in Laurel Hill Creek Basin, southwestern, Pennsylvania, 2001

4. Map showing average annual precipitation in the Laurel Hill Creek Basin, southwestern, Pennsylvania, from 1971-2000.

5. Map showing average aannual daily maximum air temperatures in the Laurel Hill Creek Basin, southwestern, Pennsylvania, 1971-2000.

6. Map showing average annual daily minimum air temperatures in the Laurel Hill Creek Basin, southwestern, Pennsylvania, 1971-2000.

7. Map showing the bedrock geology in Laurel Hill Creek Basin, southwestern, Pennsylvania 
8. Map showing surface-water sites sampled for water quality and streamflow in Laurel Hill Creek Basin, southwestern Pennsylvania, June and September 2007 ..........14

9. Map showing locations of stream-temperature probes in Laurel Hill Creek, southwestern, Pennsylvania.

10. Map showing locations of groundwater sites sampled for water quality and the U.S. Geological Survey observation well for Somerset County in Laurel Hill Creek Basin, southwestern, Pennsylvania, July-August and October 2007.

11. Map showing locations of registered groundwater-withdrawal well sites and sites of permitted discharges to, and registered withdrawals from, surface water in Laurel Hill Creek Basin, southwestern, Pennsylvania

12. Pie chart showing percentage of water withdrawn, by selected categories, within Laurel Hill Creek Basin, southwestern, Pennsylvania, using 2003 water-use data.........19

13. Schematic diagram of the Precipitation-Runoff Modeling System . .21

14. Boxplots showing distribution of selected water-quality constituents in surfacewater samples collected at main stem and tributary sites in the Laurel Hill Creek Basin, southwestern, Pennsylvania, 2007

15. Map showing chloride and sodium concentrations measured in the upper part of the Laurel Hill Creek Basin, southwestern, Pennsylvania, 2007

16. Map showing specific conductance values measured in the upper part of the Laurel Hill Creek Basin, southwestern, Pennsylvania, 2007.

17. Boxplots showing distribution of selected water-quality constituents, by geologic unit, in surface-water samples collected at tributary sites in the Laurel Hill Creek Basin, southwestern, Pennsylvania, 2007

18. Graphs showing stream temperatures for $A$, July 2008 and $B$, February 2009 for five sites along the main stem of Laurel Hill Creek, southwestern, Pennsylvania

19. Boxplots showing distribution of selected water-quality constituents, by geologic unit, in groundwater (wells and springs) samples collected in the Laurel Hill Creek Basin, southwestern, Pennsylvania, 2007

20. Map showing Hydrologic Response Units (HRU) in the Laurel Hill Creek Basin, southwestern, Pennsylvania, generated for the GSFLOW model

21. Map showing finite-difference grid with simulated streams, wells, and quarry pit withdrawal in the groundwater-flow model MODFLOW in the Laurel Hill Creek Basin, southwestern, Pennsylvania

22. Map showing MODFLOW grid with the distribution of hydraulic conductivity values assigned to the steady-state groundwater-flow model for the Laurel Hill Creek Basin, southwestern, Pennsylvania

23. Map showing simulated steady-state water table for the steady-state groundwaterflow model for the Laurel Hill Creek Basin, southwestern, Pennsylvania

24. Graphs showing time series plots of observed daily streamflow at the Laurel Hill Creek at Ursina, Pennsylvania, streamflow-gaging station 03080000 and simulated streamflow from the GSFLOW model for the Laurel Hill Creek Basin, southwestern, Pennsylvania: $A, 1991-95, B, 1996-99, C, 2000-03$, and $D, 2004-07$.

25. Graph showing time series plot of the residuals (observed minus simulated streamflow) for Laurel Hill Creek at Ursina, Pennsylvania, station 03080000 from the GSFLOW model for January 1, 1991, through September 29, 2007.

26. Graph showing residuals from the GSFLOW model (observed minus simulated streamflow values) for January 1, 1991, through September 29, 2007, in relation to the daily base-flow fraction, as derived by the hydrograph separation program PART for the Laurel Hill Creek at Ursina, Pennsylvania, streamflow-gaging station (03080000). 


\section{Tables}

1. Daily average maximum, minimum, and mean stream temperatures by season at five sites located along the main stem of Laurel Hill Creek, southwestern, Pennsylvania, 2007-10.

2. Median values for specific conductance, $\mathrm{pH}$, iron, and manganese, by geologic formation, for spring and well water samples collected in the Laurel Hill Creek Basin, southwestern, Pennsylvania, 2007

3. Measured streamflow and drainage area for surface-water sites sampled in the Laurel Hill Creek Basin, southwestern Pennsylvania, 2007.

4. Summary of water discharges and withdrawals within Laurel Hill Creek Basin, southwestern, Pennsylvania, 2009...

5. Summary of water withdrawals, discharges, and screening indicators from the Water Analysis Screening Tool (WAST) for stream sites in the Laurel Hill Creek Basin, southwestern, Pennsylvania, 2009

6. Description of climate stations used for input to the Laurel Hill Creek Basin, southwestern, Pennsylvania, GSFLOW model.

7. Description of solar-radiation stations used for input to the Laurel Hill Creek Basin, southwestern, Pennsylvania, GSFLOW model

8. Description of modules used in the GSFLOW model for the Laurel Hill Creek Basin, southwestern, Pennsylvania

9. Description of parameters used in the coupled GSFLOW model for the Laurel Hill Creek Basin, southwestern, Pennsylvania, and modules that invoke that particular parameter

10. Description of dimension parameters used in the GSFLOW model for the Laurel Hill Creek Basin, southwestern, Pennsylvania.

11. Summary of GSFLOW model parameters for Laurel Hill Creek Basin, southwestern, Pennsylvania, including dimensions, number of values specified, units, minimum, maximum, mean, the acceptable range, and default values for each parameter.

12. Summary of discharges to, and withdrawals from, surface water simulated in the SFR2 streamflow-routing package of the steady-state groundwater model for the Laurel Hill Creek Basin, southwestern, Pennsylvania.

13. Groundwater withdrawals from wells simulated in the MODFLOW_NWT steady-state model for the Laurel Hill Creek Basin, southwestern, Pennsylvania

14. Observed (July and October 2007) and simulated water levels at groundwater wells used to adjust the steady state groundwater-flow model (MODFLOW) for the Laurel Hill Creek Basin, southwestern, Pennsylvania

15. Observed streamflow and GSFLOW simulated components of the water budget for the Laurel Hill Creek Basin, southwestern, Pennsylvania, 1991-2007. Simulation was for January 1, 1991, to September 29, 2007.

16. Mean and median percent differences between observed and simulated (GSFLOW) daily streamflows, by percent base-flow estimates, derived by the PART program for the Laurel Hill Creek at Ursina, Pennsylvania, streamflowgaging station (03080000), January 1, 1991, through September 29, 2007. 


\section{Conversion Factors}

Inch/Pound to SI

\begin{tabular}{|c|c|c|}
\hline Multiply & By & To obtain \\
\hline \multicolumn{3}{|c|}{ Length } \\
\hline inch (in.) & 2.54 & centimeter $(\mathrm{cm})$ \\
\hline foot $(\mathrm{ft})$ & 0.3048 & meter $(\mathrm{m})$ \\
\hline mile (mi) & 1.609 & kilometer (km) \\
\hline \multicolumn{3}{|c|}{ Area } \\
\hline acre & 0.4047 & hectare (ha) \\
\hline square mile $\left(\mathrm{mi}^{2}\right)$ & 2.590 & square kilometer $\left(\mathrm{km}^{2}\right)$ \\
\hline \multicolumn{3}{|c|}{ Volume } \\
\hline gallon (gal) & 3.785 & liter (L) \\
\hline cubic foot $\left(\mathrm{ft}^{3}\right)$ & 0.02832 & cubic meter $\left(\mathrm{m}^{3}\right)$ \\
\hline \multicolumn{3}{|c|}{ Flow rate } \\
\hline foot per day (ft/d) & 0.3048 & meter per day $(\mathrm{m} / \mathrm{d})$ \\
\hline cubic foot per second $\left(\mathrm{ft}^{3} / \mathrm{s}\right)$ & 0.02832 & cubic meter per second $\left(\mathrm{m}^{3} / \mathrm{s}\right)$ \\
\hline gallon per minute (gal/min) & 0.06309 & liter per second $(\mathrm{L} / \mathrm{s})$ \\
\hline gallon per day (gal/d) & 0.003785 & cubic meter per day $\left(\mathrm{m}^{3} / \mathrm{d}\right)$ \\
\hline million gallons per day (Mgal/d) & 3,785 & cubic meter per day $\left(\mathrm{m}^{3} / \mathrm{d}\right)$ \\
\hline inch per year (in/yr) & 25.4 & millimeter per year (mm/yr) \\
\hline \multicolumn{3}{|c|}{ Hydraulic conductivity } \\
\hline foot per day (ft/d) & 0.3048 & meter per day $(\mathrm{m} / \mathrm{d})$ \\
\hline
\end{tabular}

Temperature in degrees Celsius $\left({ }^{\circ} \mathrm{C}\right)$ may be converted to degrees Fahrenheit $\left({ }^{\circ} \mathrm{F}\right)$ as follows: ${ }^{\circ} \mathrm{F}=\left(1.8 x^{\circ} \mathrm{C}\right)+32$.

Vertical coordinate information is referenced to the North American Vertical Datum of 1988 (NAVD 88).

Horizontal coordinate information is referenced to the North American Datum of 1983 (NAD 83). Specific conductance is given in microsiemens per centimeter at 25 degrees Celsius $(\mu \mathrm{S} / \mathrm{cm}$ at $\left.25^{\circ} \mathrm{C}\right)$.

Concentrations of chemical constituents in water are given either in milligrams per liter ( $\mathrm{mg} / \mathrm{L})$ or micrograms per liter ( $\mu \mathrm{g} / \mathrm{L})$. 



\title{
Water Quality and Quantity and Simulated Surface-Water and Groundwater Flow in the Laurel Hill Creek Basin, Southwestern Pennsylvania, 1991-2007
}

\author{
By Daniel G. Galeone, Dennis W. Risser, Lee W. Eicholtz, and Scott A. Hoffman
}

\section{Abstract}

Laurel Hill Creek is considered one of the most pristine waterways in southwestern Pennsylvania and has high recreational value as a high-quality cold-water fishery; however, the upper parts of the basin have documented water-quality impairments. Groundwater and surface water are withdrawn for public water supply and the basin has been identified as a Critical Water Planning Area (CWPA) under the State Water Plan. The U.S. Geological Survey, in cooperation with the Somerset County Conservation District, collected data and developed modeling tools to support the assessment of water-quality and water-quantity issues for a basin designated as a CWPA. Streams, springs, and groundwater wells were sampled for water quality in 2007. Streamflows were measured concurrent with water-quality sampling at main-stem sites on Laurel Hill Creek and tributaries in 2007. Stream temperatures were monitored continuously at five main-stem sites from 2007 to 2010. Water usage in the basin was summarized for 2003 and 2009 and a Water-Analysis Screening Tool (WAST) developed for the Pennsylvania State Water Plan was implemented to determine whether the water use in the basin exceeded the "safe yield" or "the amount of water that can be withdrawn from a water resource over a period of time without impairing the long-term utility of a water resource." A groundwater and surface-water flow (GSFLOW) model was developed for Laurel Hill Creek and calibrated to the measured daily streamflow from 1991 to 2007 for the streamflowgaging station near the outlet of the basin at Ursina, Pa. The CWPA designation requires an assessment of current and future water use. The calibrated GSFLOW model can be used to assess the hydrologic effects of future changes in water use and land use in the basin.

Analyses of samples collected for surface-water quality during base-flow conditions indicate that the highest nutrient concentrations in the main stem of Laurel Hill Creek were at sites in the northeastern part of the basin where agricultural activity is prominent. All of the total nitrogen $(\mathrm{N})$ and a majority of the total phosphorus $(\mathrm{P})$ concentrations in the main stem exceeded regional nutrient criteria levels of 0.31 and 0.01 milligrams per liter $(\mathrm{mg} / \mathrm{L})$, respectively. The highest total $\mathrm{N}$ and total $\mathrm{P}$ concentrations in the main stem were 1.42 and $0.06 \mathrm{mg} / \mathrm{L}$, respectively. Tributary sites with the highest nutrient concentrations are in subbasins where treated wastewater is discharged, such as Kooser Run and Lost Creek. The highest total $\mathrm{N}$ and total $\mathrm{P}$ concentrations in subbasins were 3.45 and $0.11 \mathrm{mg} / \mathrm{L}$, respectively. Dissolved chloride and sodium concentrations were highest in the upper part of the basin downstream from Interstate 76 because of road deicing salts. The mean base-flow concentrations of dissolved chloride and sodium were 117 and $77 \mathrm{mg} / \mathrm{L}$, respectively, in samples from the main stem just below Interstate 76, and the mean concentrations in Clear Run were 210 and $118 \mathrm{mg} / \mathrm{L}$, compared to concentrations less than $15 \mathrm{mg} / \mathrm{L}$ in tributaries that were not affected by highway runoff. Water quality in forested tributary subbasins underlain by the Allegheny and Pottsville Formations was influenced by acidic precipitation and, to a lesser extent, the underlying geology as indicated by $\mathrm{pH}$ values less than 5.0 and corresponding specific conductance ranging from 26 to 288 microsiemens per centimeter at 25 degrees Celsius for some samples; in contrast, $\mathrm{pH}$ values for main stem sites ranged from 6.6 to 8.5. Manganese $(\mathrm{Mn})$ was the only dissolved constituent in the surface-water samples that exceeded the secondary maximum contaminant level (SMCL). More than one-half the samples from the main stem had Mn concentrations exceeding the SMCL level of 50 micrograms per liter $(\mu \mathrm{g} / \mathrm{L})$, whereas only 19 percent of samples from tributaries exceeded the SMCL for Mn.

Stream temperatures along the main stem of Laurel Hill Creek became higher moving downstream. During the summer months of June through August, the daily mean temperatures at the five sites exceeded the limit of 18.9 degrees Celsius $\left({ }^{\circ} \mathrm{C}\right)$ for a cold-water fishery. The maximum instantaneous values for each site ranged from 27.2 to $32.8^{\circ} \mathrm{C}$. 
Water-quality samples collected at groundwater sites (wells and springs) indicate that wells developed within the Mauch Chunk Formation had the best water quality, whereas wells developed within the Allegheny and Pottsville Formations yielded the poorest water quality. Waters from the Mauch Chunk Formation had the highest median pH (7.6) and alkalinity ( $80 \mathrm{mg} / \mathrm{L}$ calcium carbonate) values. The lowest $\mathrm{pH}$ and alkalinity median values were in waters from the Allegheny and Pottsville Formations. Groundwater samples collected from wells in the Allegheny and Pottsville Formations also had the highest concentrations of dissolved iron $(\mathrm{Fe})$ and dissolved Mn. Seventy-eight percent of the groundwater samples collected from the Allegheny Formation exceeded the SMCL of $300 \mu \mathrm{g} / \mathrm{L}$ for Fe and $50 \mu \mathrm{g} / \mathrm{L}$ for Mn. Forty-three and 62 percent of the groundwater samples collected from the Pottsville Formation exceeded the SMCL for iron and Mn, respectively. The highest $\mathrm{Fe}$ and $\mathrm{Mn}$ concentrations for surface waters were measured for tributaries draining the Pottsville Formation. The highest median Fe concentration for tributaries was in samples from streams draining the Allegheny Formation.

During base-flow conditions, the streamflow per unit area along the main stem of Laurel Hill Creek was lowest in the upper parts of the basin [farthest upstream site 0.07 cubic foot per second per square mile $\left.\left(\mathrm{ft}^{3} / \mathrm{s} / \mathrm{mi}^{2}\right)\right]$ and highest (two sites averaging about $0.20\left(\mathrm{ft}^{3} / \mathrm{s} / \mathrm{mi}^{2}\right)$ immediately downstream from Laurel Hill Lake in the center of the basin. Tributaries with the highest streamflow per unit area were those subbasins that drain the western ridge of the Laurel Hill Creek Basin. The mean streamflow per unit area for tributaries draining areas that extend into the western ridge and draining eastern or central sections was 0.24 and $0.05 \mathrm{ft}^{3} / \mathrm{s} / \mathrm{mi}^{2}$, respectively. In general, as the drainage area increased for tributary basins, the streamflow per unit area increased.

Criteria established by the Pennsylvania Department of Environmental Protection indicate that the safe yield of water withdrawals from the Laurel Hill Creek Basin is 1.43 million gallons per day (Mgal/d). Water-use data for 2009 indicate that net (water withdrawals subtracted by water discharges) water withdrawals from groundwater and surface-water sources in the basin were approximately $1.93 \mathrm{Mgal} / \mathrm{d}$. Water withdrawals were concentrated in the upper part of the basin with approximately 80 percent of the withdrawals occurring in the upper $36 \mathrm{mi}^{2}$ of the basin. Three subbasins-Allen Creek,

Kooser Run, and Shafer Run - in the upper part were affected the most by water withdrawals such that safe yields were exceeded by more than 1,000 percent in the first two and more than 500 percent in the other. In the subbasin of Shafer Run, intermittent streamflow characterizes sections that historically have been perennial.

The GSFLOW model of the Laurel Hill Creek Basin is a simple one-layer representation of the groundwater flow system. The GSFLOW model was primarily calibrated to reduce the error term associated with base-flow periods. The total amount of observed streamflow at the Laurel Hill Creek at Ursina, Pa. streamflow-gaging station and the simulated streamflow were within 0.1 percent over the entire modeled period; however, annual differences between simulated and observed streamflow showed a range of -27 to 24 percent from 1992 to 2007 with nine of the years having less than a 10-percent difference. The primary source of simulated streamflow in the GSFLOW model was the subsurface (interflow;

62 percent), followed by groundwater ( 25 percent) and surface runoff (13 percent). Most of the simulated subsurface flow that reached the stream was in the form of slow flow as opposed to preferential (fast) interflow.

\section{Introduction}

Laurel Hill Creek drains a basin of approximately 125 square miles $\left(\mathrm{mi}^{2}\right)$ in Somerset, Fayette, and Westmoreland Counties in southwestern Pennsylvania. The basin is managed as "Special Protection Waters" by the Pennsylvania Department of Environmental Protection (PaDEP) (Commonwealth of Pennsylvania, 2009). A water body gains special protection status if it has been designated High Quality Water and (or) Exceptional Value Waters (Pennsylvania Department of Conservation and Natural Resources, 2003). The entire main stem and most tributaries of Laurel Hill Creek are classified as a High Quality Coldwater Fishery (HQ-CWF) with four Exceptional Value (EV) tributaries. Water is withdrawn from groundwater and surface-water sources to supply multiple users, including two resorts, three golf courses, a limestone quarry, and the Borough of Somerset. There is concern that water use is exceeding water availability.

The Water Resources Planning Act of 2002 (Act 220; 27 PA C.S. $\S 3101$ et seq.) required that PaDEP update the Pennsylvania State Water Plan by 2008. One of the main objectives of this update was the identification of areas in the State where water demand exceeds the potable supply of water (PaDEP, 2006a). The State developed criteria to determine whether water demand in a basin was excessive relative to supply. In general, if water demand far exceeds supply, the basin would be designated as a Critical Water-Planning Area (CWPA). A CWPA is defined as a "significant hydrologic unit where existing or future demands exceed or threaten to exceed the safe yield of available water resources" (PaDEP, 2006b). A water-analysis screening tool (WAST) was developed by the U.S. Geological Survey (USGS), in cooperation with the PaDEP, to provide assistance to the State in the identification of CWPAs (Stuckey, 2008). The Laurel Hill Creek Basin is one of the basins in the State that was the focus for some of the initial work in updating the State Water Plan. The WAST was implemented for this work to determine whether water demand exceeded water supply in the Laurel Hill Creek Basin. This initial work under the auspices of the State Water Plan was conducted using 2003 water-use data provided by PaDEP. For the project on which this report is based, the initial WAST results were expanded upon by applying the WAST to specific subbasins, again using 2003 water-use data. The WAST also 
was used to determine whether water use exceeded safe yields in the basin by using water-use data compiled for 2009 .

Laurel Hill Creek is in the Ohio River watershed; hence, the Ohio Regional Water Resources Committee (ORWRC), one of six Regional Water Resources Committees in Pennsylvania created as a result of Act 220 to address water issues across the entire State (PaDEP, 2009), is involved in making water planning decisions. Initial work documenting water use that exceeded safe yields in the basin based on WAST results prompted the ORWRC to accept the nomination of the Laurel Hill Creek Basin as a CWPA. Eventually, this nomination was forwarded to the statewide committee and in December 2010, the Laurel Hill Creek Basin was approved as a CWPA.

Under the context of Pennsylvania's State Water Plan, a Critical Area Resource Plan (CARP) needs to be developed for any area designated as a CWPA. According to the PaDEP (2006b), the following criteria need to be addressed in the development of a CARP:

(i) An identification of existing and future reasonable and beneficial uses.

(ii) A water availability evaluation, including a quantitative assessment of the available water resources and their relationship to the existing and future reasonable and beneficial uses.

(iii) An identification of the quantity of water available for new or increased uses of water in the foreseeable future and an identification of quantities required for future water uses associated with planned projects or developments.

(iv) An assessment of water quality issues that have a direct and substantial effect on water resource availability.

(v) A consideration of storm water and floodplain management within the critical water planning area and their impacts on water quality and quantity.

(vi) Identification of existing and potential adverse impacts on uses or conflicts among users or areas of the critical water planning area and identification of alternatives for avoiding or resolving such conflicts.

(vii) An identification of practicable supply-side and demand-side alternatives for assuring an adequate supply of water to satisfy existing and future reasonable and beneficial uses."

The focus of this study was to assess the quality and quantity of groundwater and surface-water sources in the Laurel Hill Creek Basin, assess the effects of current demands for water in the basin, and provide a tool for future water demands. For this study, conducted by the USGS in cooperation with the Somerset County Conservation District, water quality in the basin was assessed in summer and fall 2007. Two groundwater and surface-water sampling events were conducted in the basin during periods of little to no precipitation; therefore, the samples were indicative of base-flow or low-flow periods. Stream samples were collected in tributaries and along the main stem of the Laurel Hill Creek. Streamflow was measured for each surface-water sample collected. Groundwater samples were collected from springs and wells.
Spring discharge was measured prior to the collection of water-quality samples from springs; static water level was measured and wells were purged prior to collecting waterquality samples from wells. Stream quality classification can also be defined by water temperature, with maximum temperature limits corresponding to protected uses for cold-water or warm-water fishes and associated aquatic life (Commonwealth of Pennsylvania, 2009). A network of stream temperature probes was operated from 2007 to 2010 along the main stem of Laurel Hill Creek in order to characterize the temperature regime, which is an important characteristic for a stream designated as a HQ-CWF.

Considering that withdrawals in the basin are taken from both groundwater and surface-water resources, it is critical to understand the interaction between the groundwater and surface-water systems. An integrated hydrologic model called GSFLOW (Groundwater and Surface-water FLOW) was developed by the USGS to simulate interactions between groundwater and surface-water resources. This model is based on the coupling of the USGS Modular Groundwater Flow Model (MODFLOW) (Harbaugh, 2005) and the USGS Precipitation-Runoff Modeling System (PRMS) (Leavesley and others, 1983). GSFLOW can be used to evaluate the effects of such factors as land-use change, climate variability, and water withdrawals on surface and subsurface flow. The model was designed to simulate the most important processes affecting groundwater and surface-water flow using a numerically efficient algorithm (Markstrom and others, 2008).

Laurel Hill Creek is considered to be one of the most pristine streams in southwest Pennsylvania, a relatively unique distinction for streams in the area, substantiated by the fact that the entire basin is designated as a HQ-CWF (Commonwealth of Pennsylvania, 2009). Native eastern brook trout are common throughout the basin, and the basin is stocked with more than 6,000 rainbow, brown, and golden trout annually, which gives the basin high recreational value. However, the pristine nature of the basin is being degraded and additional future degradation could result if plans to protect the hydrological resources of the basin are not developed and implemented. Over the last 10 years, the upper one-third of the basin was listed as impaired by PaDEP (2014) for water-quality issues. Excessive siltation, nutrients, and organic enrichment, with resulting low dissolved oxygen (DO), from grazing and crop-related agricultural activities have been identified as the causes of these impairments in the headwaters of Laurel Hill Creek (PaDEP, 2011).

On the basis of recommendations and findings from a Rivers Conservation Plan (Crouse \& Company of Somerset and Kleinschmidt Group, 2005), basin stakeholders believe that groundwater and surface-water withdrawals also are causing streamflows to be lower than historic levels and that low streamflows are occurring more frequently. This viewpoint by the stakeholders was verified according to criteria established by the Pennsylvania Water Resources Act 220 State Water Plan, which indicates that water use in the basin far exceeds the safe yield for water withdrawals. Furthermore, 
low streamflows during the growing season could increase the potential for stream water warming, exacerbate the accumulation of fine sediment (siltation), and accelerate eutrophication and organic enrichment that result from excessive nutrients. Future development in the basin is likely (Mackin Engineering Company, 2010); therefore, planning is critical at this time to reduce the potential for further decline in the viability of the basin as an aquatic resource for both humans and wildlife.

\section{Purpose and Scope}

The purpose of this report is to document water-quality and water-quantity conditions for surface water and groundwater in the Laurel Hill Creek Basin during 1991-2007 as a framework for a water-resource management plan for an area designated as a Critical Water Planning Area within the context of the Pennsylvania State Water Plan. A GSFLOW model was developed for the basin as a tool to determine how future changes in water use and land use could affect the water availability for both human consumption and aquatic resources.

In general, this report

- documents the groundwater and surface-water quality and quantity in Laurel Hill Creek Basin;

- verifies existing water-use data for the basin and determines whether the quantity of water in the basin is stressed, based on the use of the WAST; and

- presents a discussion of the development, documentation, and interpretation of a surface-water and groundwater interaction model for the basin.

Results of the model improve the understanding of the relation between surface water and groundwater in the basin and the future effects of projected water use.

\section{Study Area}

The Laurel Hill Creek Basin is in the Allegheny Mountain Section of the Appalachian Plateau Physiographic Province (McElroy, 2000). The basin is primarily within Somerset County, but small sections of the basin on the western periphery along Laurel Hill are in Fayette and Westmoreland Counties (fig. 1). There is relatively large relief in the basin compared with the rest of the State, with elevations ranging from 1,300 feet (ft) (above North American Vertical Datum of 1988 (NAVD 88) at the outlet of the basin at Confluence, Pa., to approximately 2,990 ft on Laurel Hill (fig. 2). The western boundary of the basin is Laurel Hill, and elevations decrease from west to east. The eastern boundary of the basin is a low drainage divide with the Casselman River.

The Laurel Hill Creek Basin is 79 percent forested and 20 percent agricultural land, with only 1 percent of land developed as high/low density residential and quarries
(U.S. Geological Survey, 2004; Mackin Engineering Company, 2010) (fig. 3). According to the 2000 Census (U.S. Census Bureau, 2000), approximately 2,700 people reside in the basin. The most highly concentrated population densities occur in the southern tip of the basin in the towns of Ursina and Confluence (fig. 1). Smaller densities occur in the upper and middle sections of the basin. Future population increases are likely to occur in the middle to upper sections of the basin along the Route 31 corridor near and to the east of Bakersville, $\mathrm{Pa}$. Also, there is the potential for the two resorts in the basin, Seven Springs Mountain Resort and Hidden Valley Resort, to increase the number of housing units over the next 15 years (Mackin Engineering Company, 2010).

Twenty-nine percent of the basin is state-owned land (Crouse \& Company of Somerset and Kleinschmidt Group, 2005), which includes three State parks, State forest, and State game lands. These State lands are relatively pristine and are used primarily for recreational activities.

\section{Climate}

Annual precipitation in the basin varies spatially due to the mountainous terrain, which causes substantial orographic influences on precipitation patterns (fig. 4). For the Laurel Hill Creek Basin, the overall average precipitation for 1971-2000 was 48 inches per year (in/yr) with the variation in grid cells ranging from 44 to 58 in/yr. (PRISM Climate Group, Oregon State University, 2011). The PRISM Climate Group populated the basin with average climatic data using cell sizes of 800 meter (m) by $800 \mathrm{~m}$ (514 cells for the entire basin). The highest values for average precipitation occurred in the northwestern corner of the basin. The only continuous climate station in the basin is in Confluence, Pa., at the southern tip of the basin (fig. 1). The average precipitation for this station during 1971-2000 was 45.5 in/yr (National Climate Data Center, 2004).

Snowfall varies greatly across the basin, both spatially and seasonally. Snowfall totals recorded at Seven Springs Mountain Resort (fig. 1) from fall 2005 through spring 2010 indicate an annual average snowfall for the period of 135 inches (in.), with the minimum occurring during the 2008-09 season (98 in.) and the maximum occurring during 2009-10 (223 in.) (Jeffrey Alcorn, written commun., 2011). The average annual snowfall was $54.9 \mathrm{in}$. at Confluence for 1971-2000 (National Climate Data Center, 2004). The snow totals for Seven Springs and Confluence probably provide a reasonable estimate of the snow fall range within the basin.

Air temperatures vary across the basin owing to orographic influences. The annual average of daily maximum air temperatures range from 53.5 to 61.5 degrees Fahrenheit $\left({ }^{\circ} \mathrm{F}\right)$ (fig. 5) and average of daily minimums range from 35.6 to $39.3^{\circ} \mathrm{F}$ (fig. 6) (PRISM Climate Group, Oregon State University, 2011). On the basis of temperature data from continuous recording stations in and around the basin, the highest daily maximums and minimums occur in July, and the lowest 


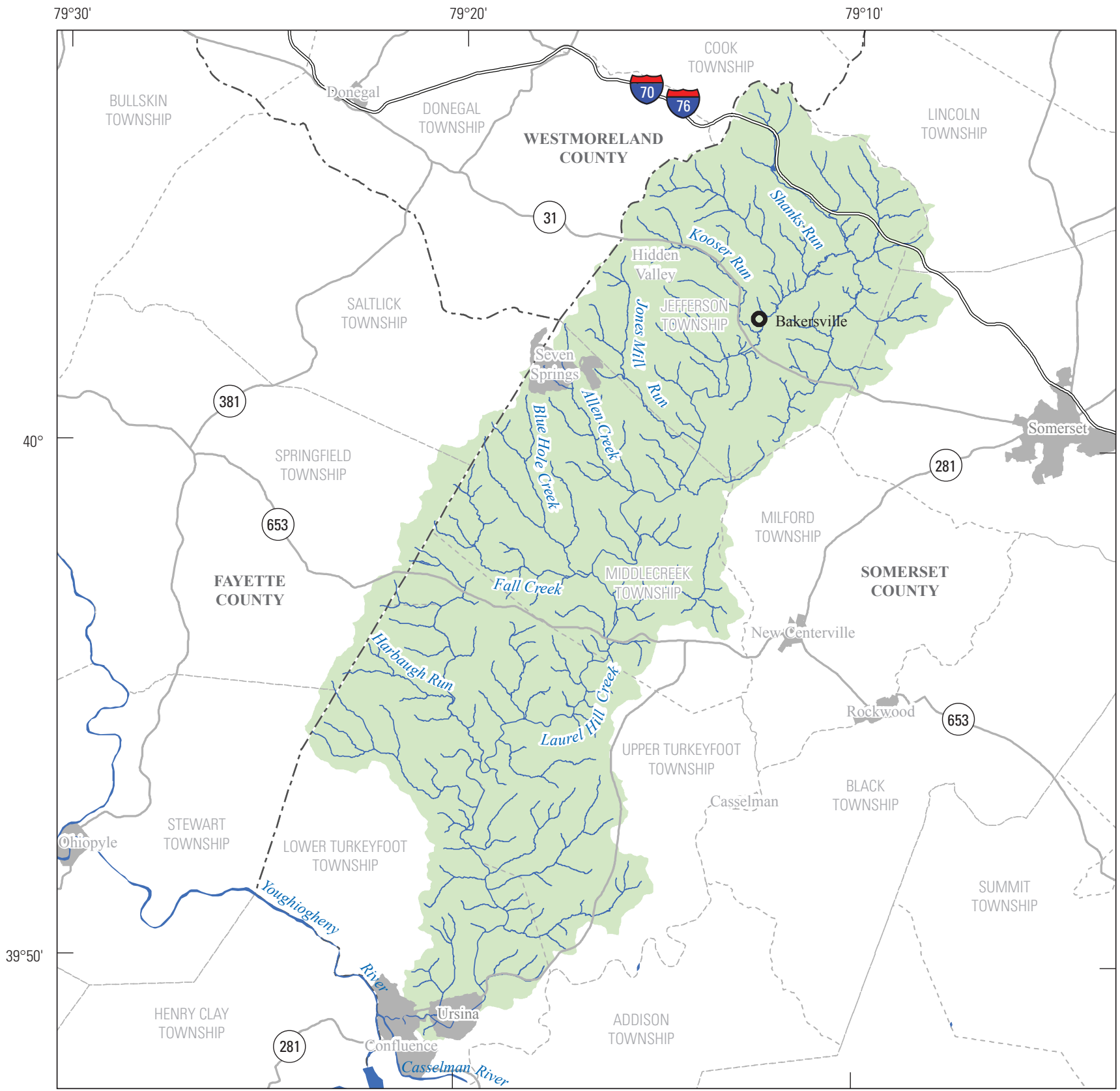

Base modified from U.S. Geological Survey 1:100,000-scale digital data, streams from U.S. Geological Survey National Hydrography Data Set, 2009, 1:100,000, county and township lines, boroughs, interstate and state highways from Pennsylvania Department of Transportation, 2009, Physiographic provinces from Pennsylvania Bureau of Topographic and Geologic Survey, Dept. of Conservation and Natural Resources, 2008

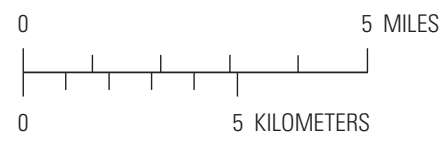

EXPLANATION

\begin{tabular}{|c|c|c|c|c|c|}
\hline 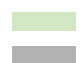 & $\begin{array}{l}\text { Laurel Hill Creek watershed } \\
\text { Borough }\end{array}$ & --- & $\begin{array}{l}\text { County line } \\
\text { Streams }\end{array}$ & $\begin{array}{c}-31- \\
0\end{array}$ & $\begin{array}{l}\text { State highway } \\
\text { Town }\end{array}$ \\
\hline & & & Interstate highway & & \\
\hline
\end{tabular}

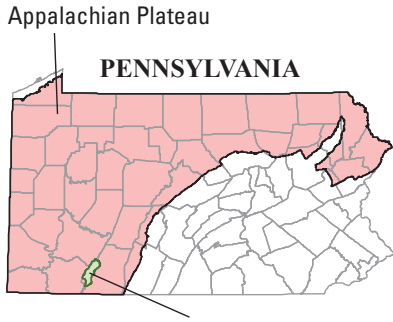

Laurel Hill Creek watershed

Figure 1. Laurel Hill Creek Basin, southwestern, Pennsylvania. 


\section{EXPLANATION}

Elevation, in feet above North American Vertical Datum of 1988

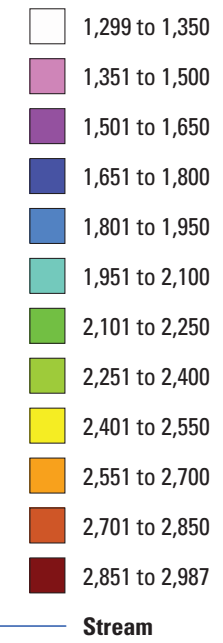

.




\section{EXPLANATION}

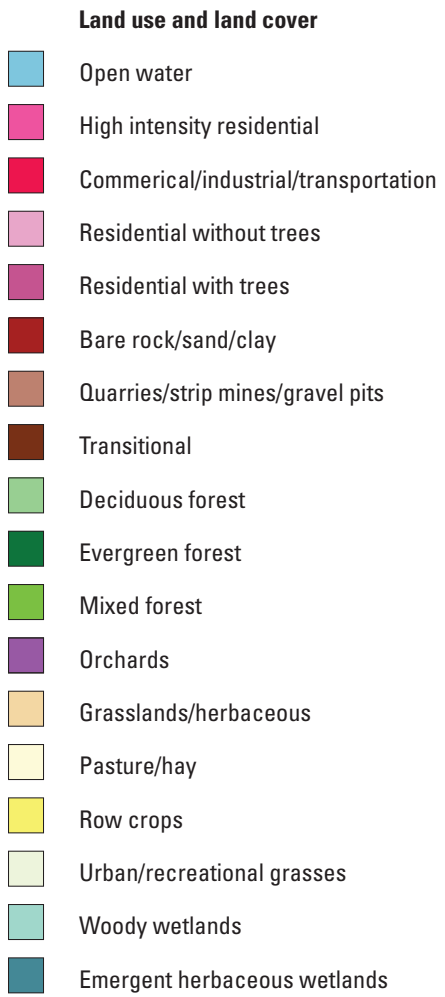

\section{Interstate highway \\ (31) State highway}

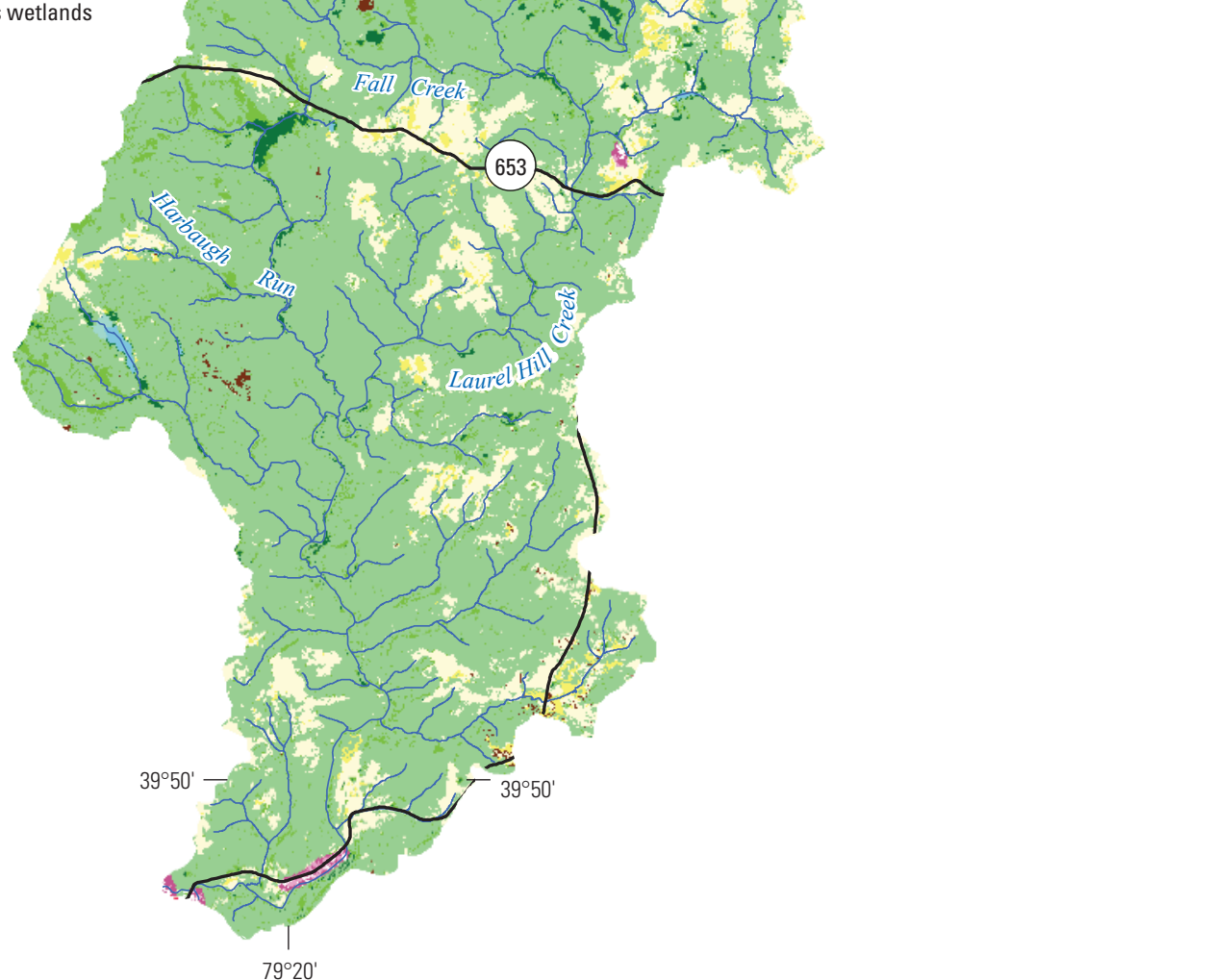

Base modified from U.S. Geological Survey 1:100,000-scale digital data, streams from U.S. Geological Survey National Hydrography Data Set, 2009, 1:100,000, interstate and state highways from Pennsylvania Department of Transportation, 2009

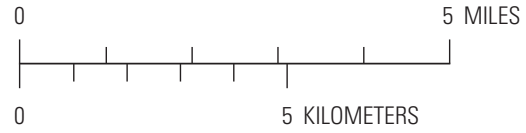

Land use and land cover from U.S. Geological Survey, 2004

Figure 3. Land use and land cover in Laurel Hill Creek Basin, southwestern, Pennsylvania, 2001. 


\section{EXPLANATION}

Average annual precipitation

in inches, from 1971 to 2000
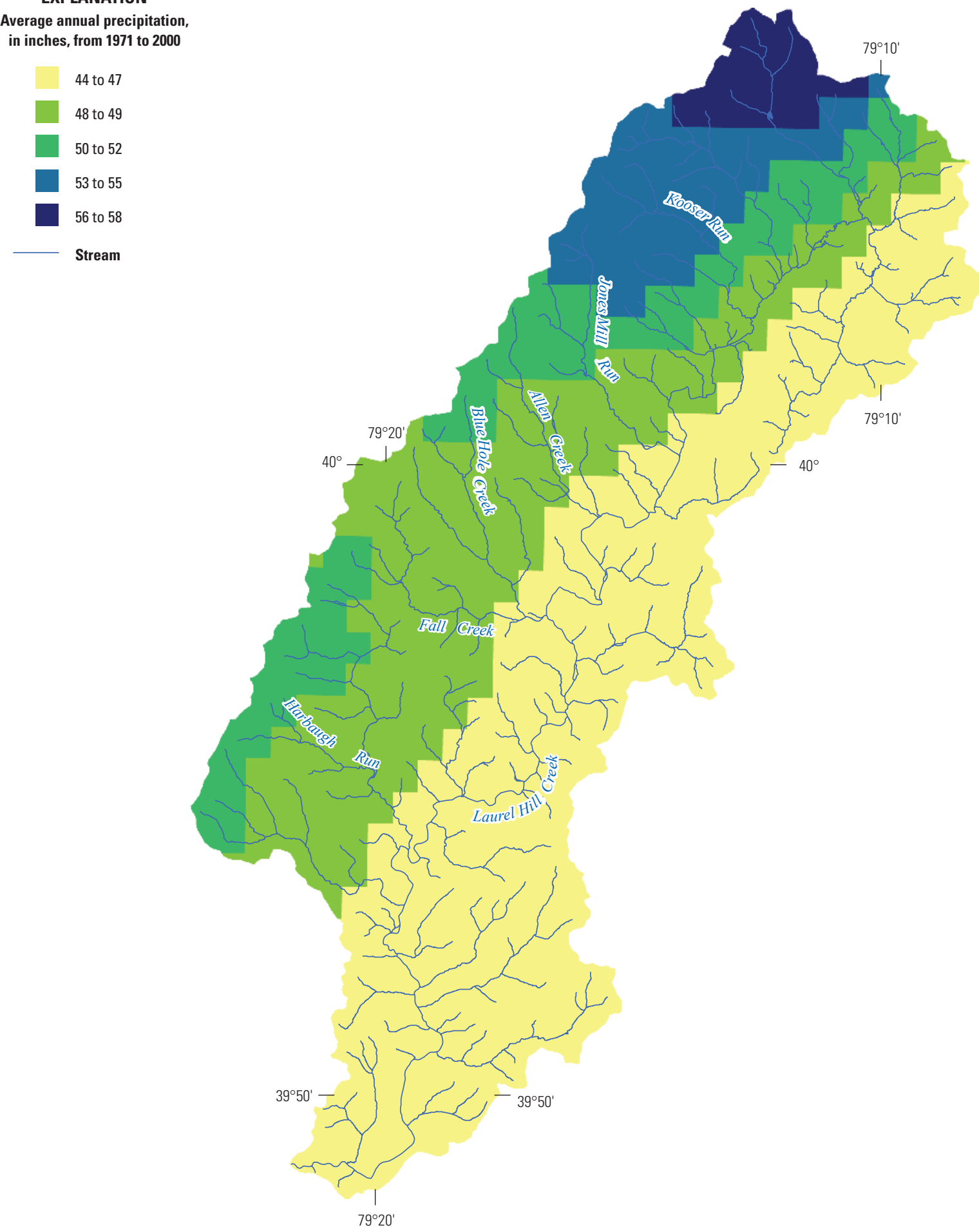

Base modified from U.S. Geological Survey 1:100,000-scale digital data, streams from U.S. Geological Survey National Hydrography Data Set, 2009, 1:100,000

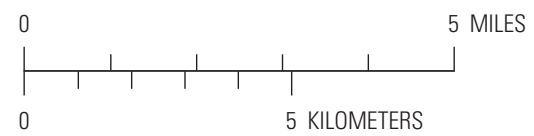

Precipitation data from The PRISM Climate Group at Oregon State University, 2011

Figure 4. Average annual precipitation in the Laurel Hill Creek Basin, southwestern, Pennsylvania, from 1971-2000. 


\section{EXPLANATION}

Average annual maximum temperature,

in degrees Fahrenheit, from 1971 to 2000

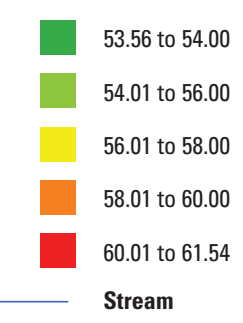




\section{EXPLANATION}

Average annual minimum temperature,

in degrees Fahrenheit, from 1971 to 2000

35.65 to 36.00
36.01 to 37.00
37.01 to 38.00
38.01 to 39.00
39.01 to 39.33
Stream

.00
.00
.00
.00

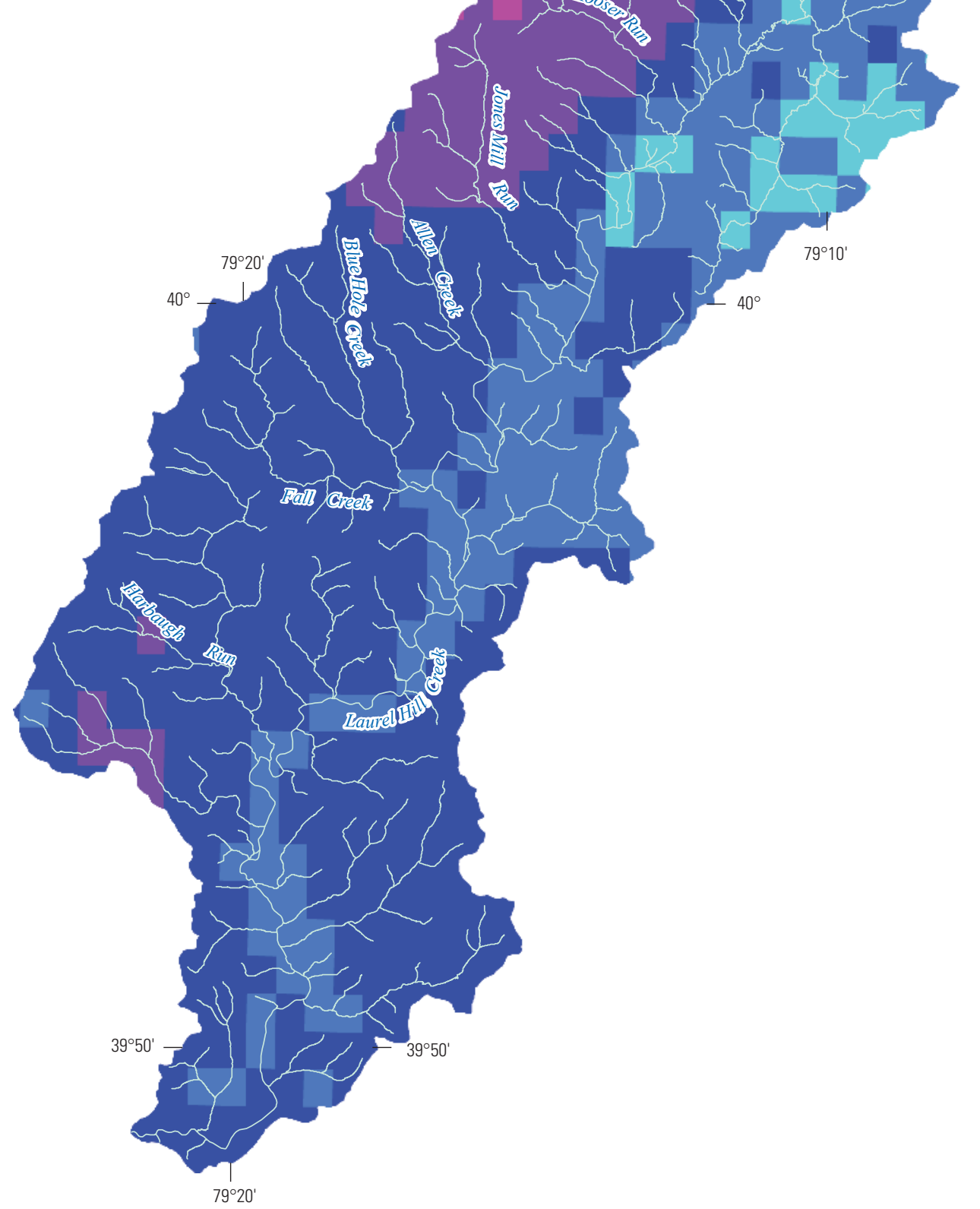

Base modified from U.S. Geological Survey 1:100,000-scale digital data, streams from U.S. Geological Survey National Hydrography Data Set, 2009, 1:100,000

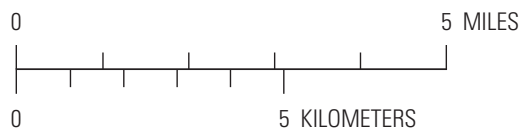

Temperature data from The PRISM Climate Groupat Oregon State University, 2011

Figure 6. Average annual daily minimum air temperatures in the Laurel Hill Creek Basin, southwestern, Pennsylvania, 1971-2000. 
daily maximums and minimums occur in January. The daily maximums range from about 75 to $85^{\circ} \mathrm{F}$ in July, and the daily minimums range from about 15 to $16^{\circ} \mathrm{F}$ in January (National Climate Data Center, 2004).

\section{Geologic Setting}

The Laurel Hill Creek Basin is underlain by sedimentary rock of the Mississippian to Pennsylvanian period, which occurred from 300 to 360 million years ago. The oldest rock exposed in the basin is that of the Mississippian-aged Burgoon Sandstone, which is overlain by the Loyalhanna Formation (limestone), then by the Mauch Chunk Formation. The Mauch Chunk Formation consists of interbedded shale/sandstones with a few beds of siltstone/limestone (Geyer and Wilshusen, 1982). The oldest Pennsylvanian-aged rocks in the basin are of the Pottsville Group, followed by the Allegheny Group, and the Conemaugh Group (composed of the Glenshaw and Casselman Formations) (McElroy, 2000). The Pottsville Group consists primarily of sandstone with interbedded shale and minor amounts of coal, claystone, siltstone, and limestone. The Allegheny group consists of alternating layers of shale, claystone, siltstone, sandstone, and coal (Geyer and Wilshusen, 1982; Crouse \& Company of Somerset and others, 2005). The Glenshaw and Casselman Formations in the Conemaugh Group are heterogeneous formations. The Glenshaw Formation consists of repeated sequences of sandstone, siltstone, claystone, limestone, and coal, whereas the Casselman Formation is composed of alternating layers of shale, siltstone, sandstone, and some thin limestone layers (Crouse \& Company of Somerset and Kleinschmidt Group, 2005). The Mississippianage rocks predominate in the west to northwestern section of the basin, whereas the Pennsylvanian-age rocks dominate in the remaining sections of the basin. The most common rock underlying the surface is the Allegheny Formation, followed by the Casselman and Pottsville Formations (fig. 7).

All of the rock formations in the Laurel Hill Creek Basin potentially can yield large quantities of groundwater. The public-supply wells in the basin are completed in the Mauch Chunk Formation. The Loyalhanna Formation is the source of at least two public-supply wells in other parts of Somerset County, and the Burgoon Sandstone also can be an excellent water source (McElroy, 2000). Iron and manganese concentrations greater than the U.S. Environmental Protection Agency (EPA) secondary maximum contaminant levels (SMCLs) do occur on a regular basis in each formation (McElroy, 2000). SMCLs are non-enforceable Federal guidelines regarding cosmetic or aesthetic effects. The SMCL for iron is 300 micrograms per liter $(\mu \mathrm{g} / \mathrm{L})$ and the SMCL for manganese is $50 \mu \mathrm{g} / \mathrm{L}$ (U.S. Environmental Protection Agency, 2012). The Allegheny and Pottsville Formations can also yield acidic groundwater, which can corrode plumbing.

Soil genesis in the basin was greatly affected by slope. Most soils in the basin are deep. Soils along the ridges and hill sides generally are well drained, whereas low land soils in the flood plain generally are poorly drained. The most common soils in the basin are the Rayne-Gilpin loams (U.S. Department of Agriculture, Natural Resource Conservation Service, 2004a, 2004b, 2006) that occur throughout the basin, except along the narrow ridge tops. Rayne-Gilpin loams formed in materials weathered from shale and siltstone and are moderately permeable and moderately erodible. They can be used for cropland and pasture but generally are limited to non-agricultural uses due to a typically shallow bedrock layer of $2-6$ feet (Yaworski, 1983). The second most common soil series in the basin is the Wharton series, which is derived from acidic shales. In the basin, the Wharton series generally has a silt loam texture, is moderately deep and well drained, is only slightly erodible, and is found on broad ridges and hill tops (Yaworski, 1983). These soils also can be used for cultivated crops and pasture. The third most common soil series is the Ernest soils, which are derived in colluvium from weathered shale and siltstones. The Ernest series in the basin has a silt loam to very stony silt loam texture, and these soils are deep, moderately well drained, and moderately erodible. They are found on the side slopes of hills and ridges. The phases of Ernest soil that are silt loam in texture can be used for crops and pasture, but the very stony loam texture soils of the Ernest series can be used only for trees (Yaworski, 1983).

\section{Hydrography}

Laurel Hill Creek enters the Casselman River approximately $400 \mathrm{ft}$ before the Youghiogheny River in the Borough of Confluence (fig. 1). The stream network in the Laurel Hill Creek Basin is extensive. The main stem of Laurel Hill Creek flows for approximately 38 miles with the head waters of the creek originating just south of Route 31 (southeast of Bakersville) about 5 miles west of the town of Somerset. The creek flows north towards the Pennsylvania Turnpike (Interstate 76) but makes a bend just south of the turnpike and eventually flows in a generally southerly direction until it discharges into the Casselman River. Thirty-two named tributaries and many unnamed tributaries flow into Laurel Hill Creek. The named tributaries consist of 145 miles of stream (Crouse \& Company of Somerset and Kleinschmidt Group, 2005). The main stem of Laurel Hill Creek could be considered a low-gradient stream because the slope is much flatter than that of the tributary subbasins. The tributaries, especially those on the western half of the basin that originate along the ridges, are more indicative of high-gradient streams due to the steep slopes. The tributaries in the eastern half of the basin have stream gradients that are similar to the main stem. The high gradient tributaries transport sediment rapidly to the main stem, whereas the tributaries to the east may tend to accumulate some sediment in their channels, and the transport to the main stem is more episodic. The drainage network in the basin is an integration of dendritic and parallel drainage patterns. A dendritic pattern (similar to a tree root pattern) occurs in areas where the underlying material is homogeneous, indicating that the subsurface geology has a similar resistance to weathering. A parallel drainage pattern occurs if slope controls flow patterns (Ritter, 2010). 


\title{
EXPLANATION \\ Bedrock geology \\ Burgoon Sandstone \\ Loyalhanna Formation \\ Mauch Chunk Formation \\ Allegheny Formation \\ Casselman Formation \\ Glenshaw Formation \\ Pottsville Formation \\ Stream
}

\author{
n

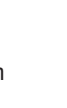

.

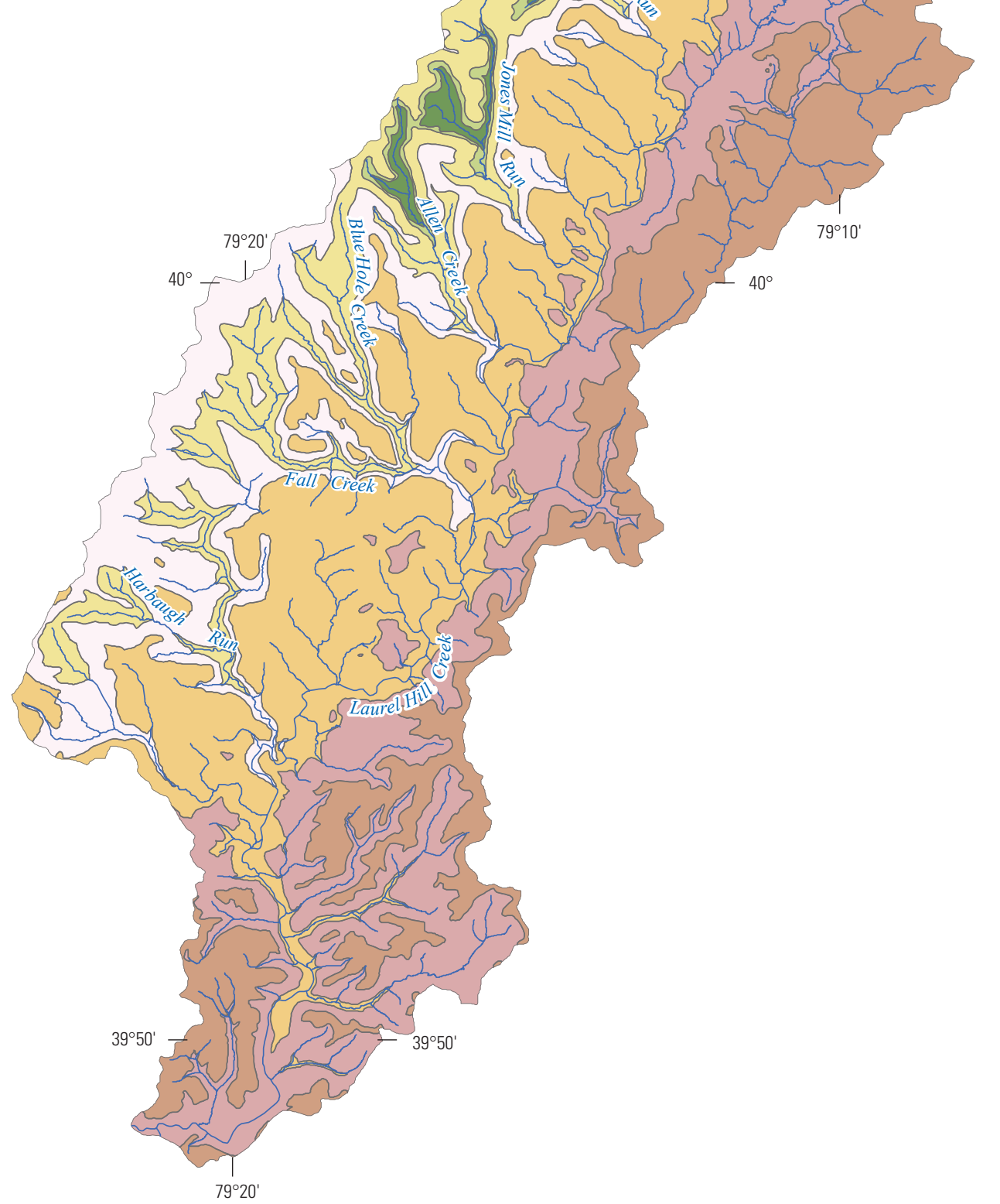

Base modified from U.S. Geological Survey 1:100,000-scale digital data, streams from U.S. Geological Survey National Hydrography Data Set, 2009, 1:100,000

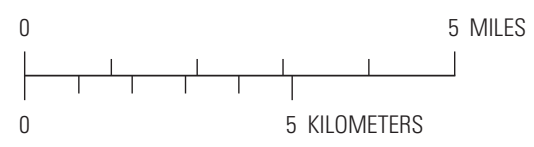

Bedrock geology from Berg and others,1980

Figure 7. The bedrock geology in Laurel Hill Creek Basin, southwestern, Pennsylvania. 
Historically, water quality in the basin has been relatively good, especially considering that some of the surrounding basins are affected by mine drainage. A snapshot of water quality in the Laurel Hill Creek Basin was conducted during 2002-03 as part of the Rivers Conservation Plan. The primary water-quality concern identified in the Rivers Conservation Plan was low $\mathrm{pH}$ values for various tributaries resulting from acidic precipitation and (or) weathering of pyritic bedrock (Crouse \& Company of Somerset and Kleinschmidt Group, 2005).

Part of the drainage network in the Laurel Hill Creek basin also has been identified as impaired by PaDEP (2011, 2014). In the upper part of the basin, 5.5 miles of a tributary and 35.5 miles of the main stem of Laurel Hill Creek are on the 2014 impaired stream list [303(d) list of PaDEP (2014)]. The tributary is impaired by nutrients (grazing related agriculture) and the main stem by organic enrichment, low dissolved oxygen, and siltation.

\section{Methods}

Water-quality and -quantity data were collected in the Laurel Hill Creek Basin during summer and fall 2007 to characterize the base-flow hydrology of the Laurel Hill Creek and the various groundwater aquifers in the basin. The amount of water used for human activities was documented using WAST on the basis of water-use data compiled for 2003 and 2009. The GSFLOW model was applied to integrate groundwater and surface-water components of the hydrologic system and to allow for water budget estimation for any location within the stream drainage network.

\section{Water Quality}

As described in more detail below, water-quality samples were collected twice in the summer-fall of 2007 during baseflow or non-recharge conditions. Stream temperature probes were installed along the main stem of Laurel Hill Creek in 2007 and operated to 2010 to characterize the spatial and temporal variations in water temperature and determine whether the thermal conditions of the stream were consistent with a system defined as a HQ-CWF.

\section{Surface Water}

Two surface-water synoptic surveys were conducted in the Laurel Hill Creek Basin on June 25-27 and September 17-19, 2007, during periods of static base flow. No significant precipitation occurred within the basin during and immediately before (4 days or less) either of the synoptic sampling periods. Thirty-seven sites were sampled during both of the synoptic studies; 31 of the sites were sampled during both synoptic studies (fig. 8). Twelve sites along the main stem of Laurel Hill Creek and 25 sites on tributaries to the main stem were sampled. Many of the surface-water sites selected for sampling were previously sampled as part of the work conducted for the Rivers Conservation Plan (Crouse \& Company of Somerset and Kleinschmidt Group, 2005).

Grab samples were collected using depth and widthintegrated measuring techniques. Field measurements included specific conductance (SC), $\mathrm{pH}, \mathrm{DO}$, and water temperature. Streamflow was measured concurrent with sampling. Alkalinities and acidities were determined in the field or at the USGS water laboratory in New Cumberland, Pa. Alkalinities were determined using the fixed endpoint $(\mathrm{pH}=4.5)$ method, and acidities were determined using the hot-peroxide acidity method (American Public Health Association and others, 1992). Samples were filtered in the field through a 0.45 -micron filter and chilled prior to shipment to the USGS National Water Quality Laboratory (NWQL) in Denver, Colorado, for chemical analyses in accordance with methods of Fishman (1993). Water samples were analyzed for dissolved concentrations of calcium $(\mathrm{Ca})$, magnesium $(\mathrm{Mg})$, sodium $(\mathrm{Na})$, iron $(\mathrm{Fe})$, manganese $(\mathrm{Mn})$, aluminum $(\mathrm{Al})$, chloride $(\mathrm{Cl})$, sulfate $\left(\mathrm{SO}_{4}\right)$, nitrate plus nitrite $\left(\mathrm{NO}_{3}+\mathrm{NO}_{2}\right)$, nitrite $\left(\mathrm{NO}_{2}\right)$, ammonia $\left(\mathrm{NH}_{3}\right)$, and phosphate $\left(\mathrm{PO}_{4}\right)$. Total concentrations of nitrogen $(\mathrm{N})$ and phosphorus $(\mathrm{P})$ also were analyzed.

Water-temperature probes were deployed at five locations along the main stem of Laurel Hill Creek stream network (fig. 9). The length of the main stem of Laurel Hill Creek from the head waters to where it drains into the Casselman River at Confluence, Pa., is about 38 stream miles. The temperature probe farthest upstream was approximately 7 miles from the start of Laurel Hill Creek identified as perennial on the USGS topographical map $(1: 24,000)$ for Bakersville, Pa. The farthest downstream temperature probe was located at Ursina, Pa., about 2 miles from the confluence of Laurel Hill Creek with the Casselman River. The temperature loggers were programmed to record temperature every 30 minutes from July 2007 until time of removal or the loggers were damaged. Data were recorded at two sites until November 2009, one site until April 2010, and two sites until July 2010. Site selection was based on critical areas identified by stakeholders. In addition, some type of structure such as a bridge abutment, was necessary to secure the loggers and avoid sensor movement. Temperature probes were attached to bridge abutments using cable wire and lag bolts. The probes did not move more than 2-3 ft after installation; therefore, the amount of sunlight that each probe was subjected to was dependent on changes in the angle of the sun caused by season.

\section{Groundwater}

Two groundwater synoptic surveys were conducted in the Laurel Hill Creek Basin in 2007. The first synoptic was conducted July 23-25 and August 1, 2007, and the second synoptic was conducted October 1-3, 2007. During and immediately before (four days or less) each synoptic study, recharge to the groundwater table was negligible. No recharge events occurred prior to, or during, sampling of the groundwater. To 


\section{EXPLANATION}

Laurel Hill Creek watershed

Lake

\section{Stream} $\begin{aligned}=\sqrt{76}= & \text { Interstate highway } \\ -31- & \text { State highway } \\ \text { LHC-A2 } \nabla & \begin{array}{l}\text { Water-quality surface-water site } \\ \text { with identifier }\end{array}\end{aligned}$

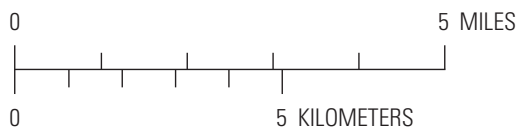

Figure 8. Surface-water sites sampled for water quality and streamflow in Laurel Hill Creek Basin, southwestern Pennsylvania, June and September 2007. 
EXPLANATION

\section{Laurel Hill Creek watershed}

Stream

$=76=$ Interstate highway

-31- State highway

Whipkey $\mathbf{R}$ Temperature gage with identifier

03079600 A U.S. Geological Survey streamflowgaging station with identifier

- Town

Base modified from U.S. Geological Survey 1:100,000-scale digital data, streams from U.S. Geological Survey National Hydrography Data Set, 2009, 1:100,000, interstate and state highways from Pennsylvania Department of Transportation, 2009

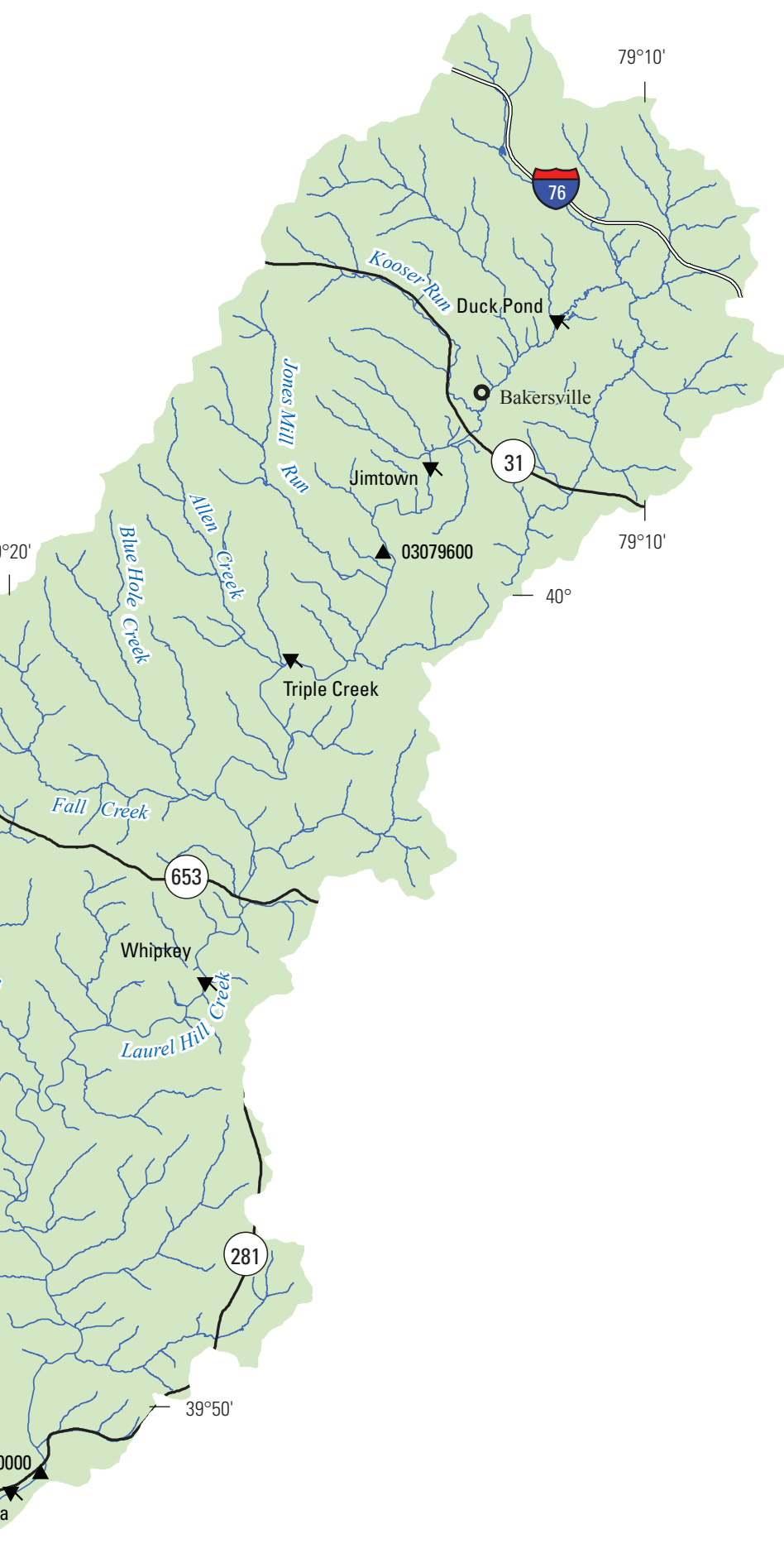

$79^{\circ} 20^{\prime}$

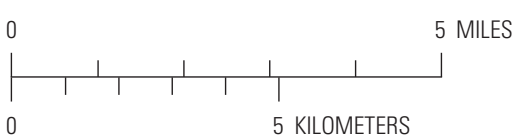

Figure 9. Locations of stream-temperature probes in Laurel Hill Creek, southwestern, Pennsylvania. 
select sampling sites, a grid with cell sizes of approximately $5-6 \mathrm{mi}^{2}$, was placed over the basin map. A well or spring within each grid cell was selected and sampled. A total of 19 groundwater wells and 7 springs were sampled during the two synoptic studies; water from 14 of the wells and 4 of the springs was sampled for both synoptic studies (fig. 10). Three of the sampled wells are public-supply wells, the remaining sites are domestic wells or springs. Groundwater samples were collected before water passed through any water-purification device. Field measurements included SC, pH, DO, oxidationreduction potential (REDOX), water temperature, and depth of water in the well below land surface. The water level in the well was recorded prior to any pumping necessary to collect the water-quality sample. Alkalinities and acidities were determined in the field or at the USGS water laboratory in New Cumberland, Pa. Alkalinities were determined using the fixed endpoint $(\mathrm{pH}=4.5)$ method, and acidities were determined using the hot-peroxide acidity method (American Public Health Association and others, 1992). Water samples from wells were collected after the SC and water temperature remained stable for 3-5 minutes. Samples were filtered in the field through a 0.45 micron filter and chilled prior to sample shipment to the USGS NWQL for chemical analyses of Ca, $\mathrm{Mg}, \mathrm{Na}, \mathrm{Fe}, \mathrm{Mn}$, arsenic (As), $\mathrm{Cl}, \mathrm{SO}_{4}$, silica $\left(\mathrm{SiO}_{2}\right), \mathrm{NO}_{3}+$ $\mathrm{NO}_{2}, \mathrm{NO}_{2}$, and $\mathrm{NH}_{3}$ in accordance with methods of Fishman (1993). For springs, analysis also included $\mathrm{Al}$ and the discharge for each spring was measured if possible.

\section{Water Quantity}

The volume of water discharging from the various subbasins and at numerous locations along the main stem of Laurel Hill Creek was quantified twice during low-flow periods in the summer and fall 2007, as described below. These data were used to show the percent contribution of subbasin streamflow of the total flow in the main stem. The WAST was implemented to determine the status of water use in the basin and the manner in which water use is potentially affecting the streamflow in the main stem.

\section{Streamflow Characterization}

Streamflow measurements at multiple cross sections along the length of the main stem of the Laurel Hill Creek and tributaries were conducted during low-flow periods with stable flow conditions. The streamflow measurements were conducted at the same time as the surface-water synoptics, so the measurements were conducted June 25-27, 2007, and Sept. 17-19, 2007. Streamflow was measured twice at 31 stream cross sections and once at 6 other locations. Streamflow measurements were conducted at 25 tributary sites and 12 main-stem sites on Laurel Hill Creek (fig. 8). The USGS streamflow-gaging station on Laurel Hill Creek at Ursina, Pa. (station 03080000), was used to determine whether stable conditions existed. No precipitation occurred prior to or during sampling; therefore, streamflow conditions were virtually static. Streamflow was measured by wading in the stream, establishing a cross section, and using an acoustic Doppler velocimeter (ADV) to measure velocity. This type of current meter uses an adaptation of the Doppler principle to measure water velocity by processing sonar reflected from suspended particulates (SonTek, 2003). Velocity and water depth were measured at 10-28 locations along each cross section. Smaller tributaries required fewer measurement locations along a cross section. The streamflow data were used to quantity the amount of water from the tributaries that contributes to the flow of the main stem of Laurel Hill Creek, and to determine where the main stem of Laurel Hill Creek was gaining or losing water to or from the shallow groundwater system. Water-withdrawal locations along the main stem were mapped to better understand results from the streamflow measurements. Drainage areas for each site were determined so that a flow per unit area could be determined.

\section{Water Use}

Water-use data for the Laurel Hill Creek Basin were compiled by PaDEP and USGS for 2003 and by the USGS for 2009. Water use was determined for both groundwater and surface-water withdrawals, and these were summed to determine a total amount of water use for the entire basin. The water-use data were verified by communicating with significant water users [a significant water user is defined as any entity withdrawing 10,000 gallons per day (gal/d) or more]. All water users withdrawing or using more than $10,000 \mathrm{gal} / \mathrm{d}$ averaged over a 30-day period and all public water agencies are required to register their water use with PaDEP (Stuckey, 2008). Registered users include water suppliers, some commercial entities, and some mineral resource companies; however, only public water suppliers need to report actual monthly water use to PaDEP. Therefore, withdrawals were estimated for some registered and all unregistered users. Unregistered users include four groups: self-supplied residential, industrial companies, any remaining commercial entities, and agricultural users. The derivation of water-use estimates for non-registered users is discussed by Stuckey (2008). For residential users (private well or spring) with septic systems, it was assumed that households used $80 \mathrm{gal} / \mathrm{d}$ with 90 percent of the water going back to the system (only 10 percent consumptive use) (Stuckey, 2008). For the Laurel Hill Creek Basin, all residential water users were assumed to use septic systems.

The Laurel Hill Creek Basin supplies public water within and outside the basin boundaries; in addition, many homeowners, businesses, and farms in the basin have private systems that tap either groundwater wells or springs for water supply. The local water authorities and municipalities withdraw groundwater and surface water within the basin (fig. 11). According to 2003 water-use data compiled by PaDEP and verified by the USGS, the total withdrawals in the basin averaged 2.27 million gallons per day (Mgal/d) with $0.26 \mathrm{Mgal} / \mathrm{d}$ discharged back into the system for a net withdrawal rate 


\section{EXPLANATION}

Laurel Hill Creek watershed

\section{Stream}

$=\overline{76}=$ Interstate highway

-31- State highway

Groundwaker site with identifier

SO SP155 $\bigcirc \quad$ Sampled spring

So $860 \bigcirc \quad$ Sampled well

SO 2

Observation well

Base modified from U.S. Geological Survey 1:100,000-scale

digital data, streams from U.S. Geological Survey National

Hydrography Data Set, 2009, 1:100,000, interstate and state

highways from Pennsylvania Department of Transportation, 2009

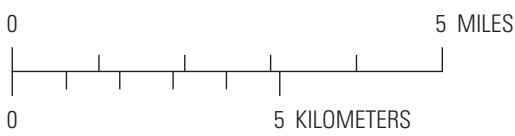

Figure 10. Locations of groundwater sites sampled for water quality and the U.S. Geological Survey observation well for Somerset County in Laurel Hill Creek Basin, southwestern, Pennsylvania, July-August and October 2007. 


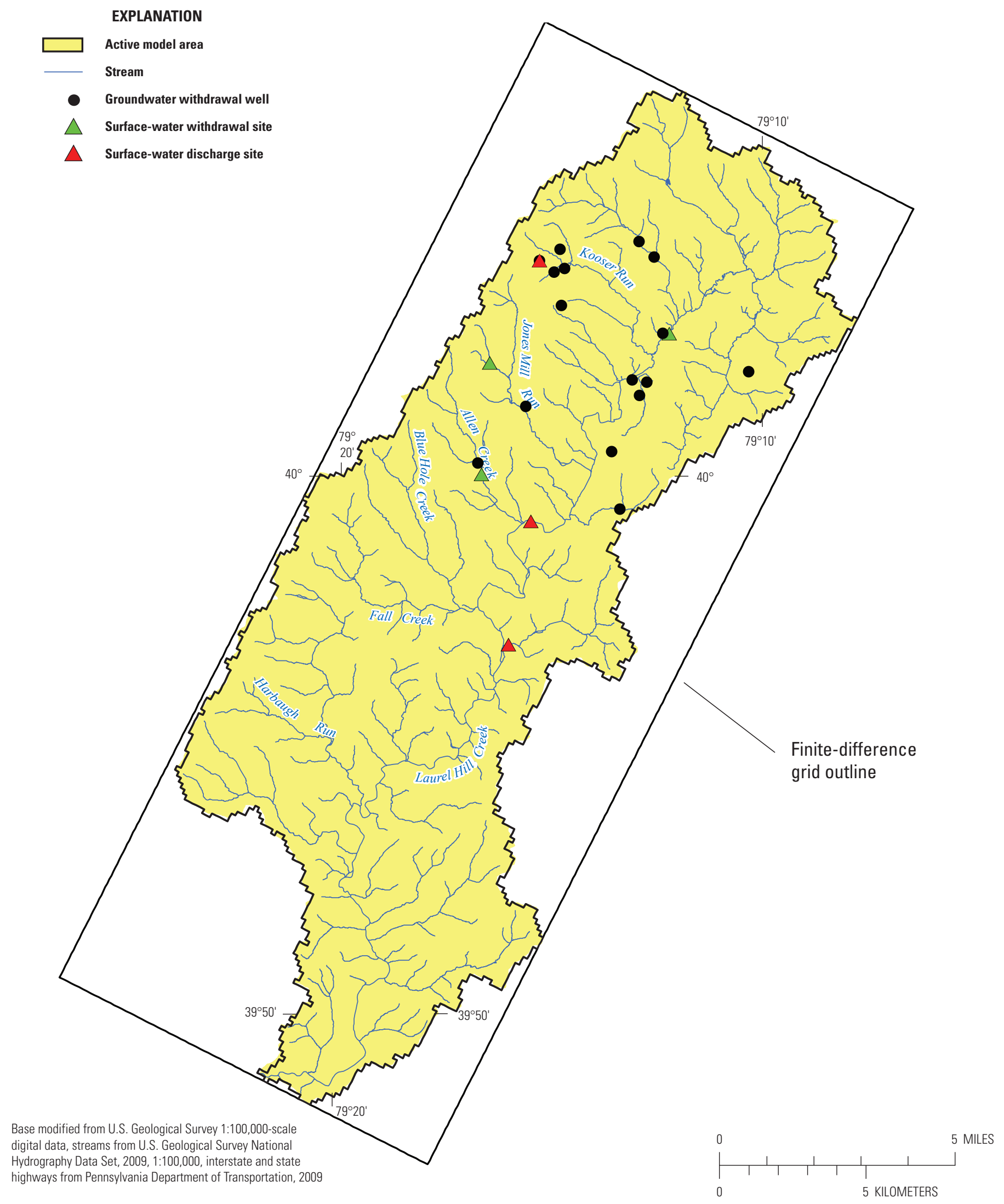

Figure 11. Locations of registered groundwater-withdrawal well sites and sites of permitted discharges to, and registered withdrawals from, surface water in Laurel Hill Creek Basin, southwestern, Pennsylvania. 
of $2.01 \mathrm{Mgal} / \mathrm{d}$. Surface-water withdrawals accounted for $1.18 \mathrm{Mgal} / \mathrm{d}$, and groundwater withdrawals accounted for the remainder. Most of the withdrawals within the basin were made by public water suppliers, who account for 68 percent of the net withdrawals (Marla Stuckey, U.S. Geological Survey, written commun., 2008) (fig. 12).
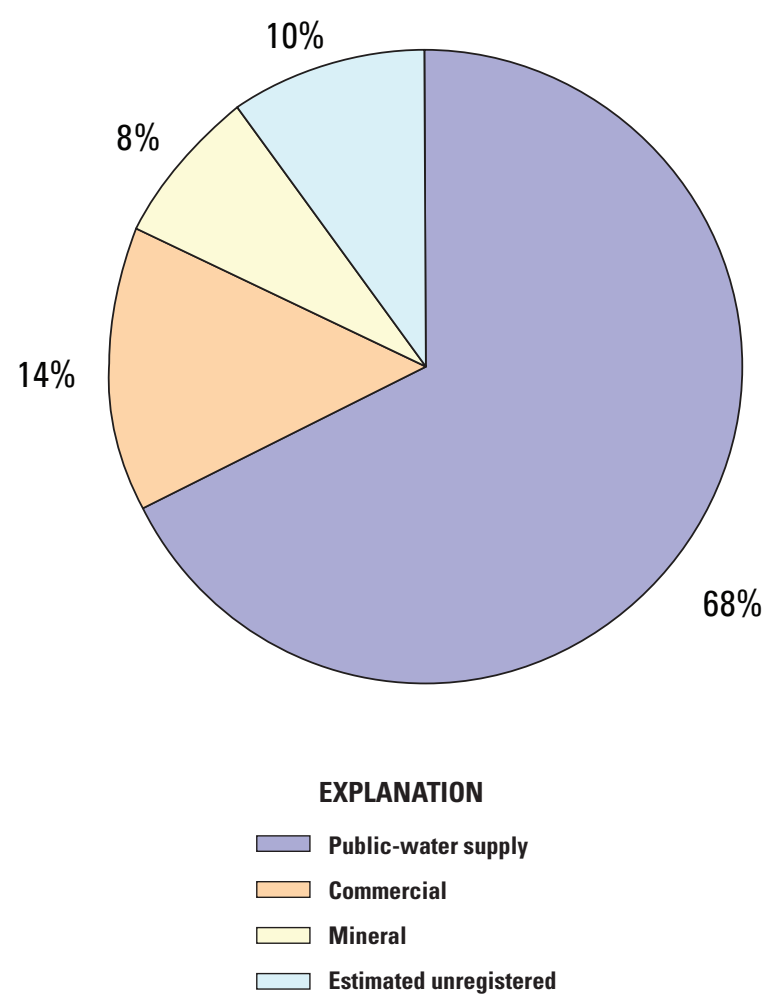

Figure 12. Percentage of water withdrawn, by selected categories, within Laurel Hill Creek Basin, southwestern, Pennsylvania, using 2003 water-use data.

The remaining withdrawals were made for commercial, unregistered (self-supplied for domestic or agricultural use), and mineral extraction uses. According to criteria established by the Commonwealth of Pennsylvania for Act 220, the net withdrawal of $2.01 \mathrm{Mgal} / \mathrm{d}$ exceeds the safe yield estimate of $1.43 \mathrm{Mgal} / \mathrm{d}$ for the basin. Safe yield is defined by PaDEP (2006b) as follows:

"For purposes of the State Water Plan, the amount of water that can be withdrawn from a water resource over a period of time without impairing the long-term utility of a water resource such as dewatering of an aquifer, impairing the long-term water quality of a water resource, inducing a health threat, or causing irreparable or unmitigated impact upon reasonable and beneficial uses of the water resource. Safe yield of a particular water source is primarily to be determined based upon the predictable rate of natural and artificial replenishment of the water source over a reasonable period of time."

\section{Water-Analysis Screening Tool (WAST)}

The WAST was run for the Laurel Hill Creek Basin using 2003 and 2009 water-use data. The WAST compares wateruse information to an initial screening criteria (ISC) that is a percentage of the 7-day, 10-year low-flow statistic (7Q10). The 7Q10 is defined as the lowest consecutive 7-day mean flow expected on average every 10 years. For areas not underlain by carbonate rock, the ISC is equal to one-half the value of the 7Q10. The net withdrawals in the basin are subtracted from the ISC value, with the result equal to the screening indicator (SI) expressed in Mgal/d. The SI is negative if net withdrawals exceed the ISC value. The SI value is divided by the ISC in order to generate a dimensionless screening indicator. This dimensionless screening indicator is multiplied by 100 to generate a screening indicator as a percentage (SIP). The SIP values are generated for different points (pour points) along the stream network to determine the potential for conflicts between water use and aquatic resources. Negative SIP values indicate the potential for conflicts between water use and aquatic life (Stuckey, 2008). At each pour point, the drainage area is determined, the water use (from groundwater and surface-water sources) in the drainage basin is estimated by the WAST, and the WAST accesses the 7Q10 estimated using statewide regression equations (Stuckey, 2006). The statewide regression equations were developed using data from 293 streamflow-gaging stations that were not affected by regulation, diversion, or mining. These equations are based on the physical characteristics of the gaged watersheds; some significant explanatory variables are drainage area, basin slope, soil thickness, stream density, precipitation, elevation, bedrock geology, and land use (Stuckey, 2006). With this information, SI and SIP values are generated, and this process can be conducted for numerous points within the stream network.

The 7Q10 used by the WAST was computed using regional regression equations developed by the USGS. Although there is a USGS streamflow-gaging station on Laurel Hill Creek at Ursina, Pa. (established in 1918), the 7Q10 for this station was not used to determine the theoretical $7 \mathrm{Q} 10$ because there are substantial daily water withdrawals from the system. Data from 293 streamflow-gaging stations were used in the regression equations developed to define statewide 7Q10 values (Stuckey, 2006).

For the State Water Plan, standard procedure was to use the WAST primarily for the main stem or the primary water body that drains the basin. For this study in the Laurel Hill Creek Basin, the WAST was used for both the main stem and selected tributary basins. Water in the Laurel Hill Creek Basin is withdrawn for water supply from both groundwater and surface-water sources. Most of the groundwater withdrawals for water supply occur in subbasins along the western periphery of the basin in upland areas. These upland areas are underlain by the Mauch Chunk Formation, which is known to yield large quantities of potable groundwater (McElroy, 2000). Although the WAST was developed for basins that are primarily greater than or equal to $15 \mathrm{mi}^{2}$ (Stuckey, 2008), in this 
study, WAST results were generated for some subbasins less than $15 \mathrm{mi}^{2}$ in areas underlain by the Mauch Chunk Formation where groundwater withdrawals were substantial.

Water-use data for the Laurel Hill Creek Basin also were compiled for 2009. The 2009 water-use data were obtained by direct communication with water users. Once the data were final, the WAST was rerun. Also, water use is most critical during drought conditions. For the Laurel Hill Creek Basin, the WAST was run for drought conditions and more typical or "normal" streamflow conditions. During drought conditions, one of the major water suppliers in the Laurel Hill Creek Basin has to meet a pass-by requirement before surface water can be withdrawn; therefore, when flows are low, the withdrawal from surface water is reduced (and SI values increase).

\section{GSFLOW Model}

GSFLOW (a groundwater and surface-water flow model developed by the USGS) is an interactive model that ties together different hydrological modeling programs. The two major components of GSFLOW are PRMS (a precipitationrunoff modeling system) and MODFLOW (the groundwater component). GSFLOW is a physically based, distributed model developed to simulate coupled groundwater/surfacewater flow in one or more basins by simultaneously simulating flow across the land surface and within subsurface saturated and unsaturated materials (Markstrom and others, 2008). The GSFLOW model is a tool that, when used in coordination with the WAST, can help to identify whether areas under water stress are primarily groundwater or surface-water related. GSFLOW can be used to evaluate the effects of land-use change, different precipitation patterns, and groundwater and (or) surface-water withdrawals on subsurface and surface flow (Markstrom and others, 2008).

GSFLOW simulates flow in three distinct regions, one of which is governed by processes and variables defined in PRMS, and the other two are governed by processes and variables defined in MODFLOW (Markstrom and others, 2008). The uppermost region extends from the top of the plant canopy to the bottom of the soil zone (or rooting depth) and is the region defined by PRMS. The second and third regions are defined by MODFLOW. The second region includes water flowing across the land surface and in streams and lakes; the third region includes subsurface water. Prior to the coupling of PRMS and MODFLOW in GSFLOW, both PRMS and MODFLOW were calibrated to observed conditions. For the GSFLOW model developed for the Laurel Hill Creek Basin, the PRMS and MODFLOW models were calibrated to streamflow data available for the USGS streamflow-gaging station in Ursina, Pa., which has been active since 1918. MODLFOW also was calibrated to water-level elevations for a network of wells that were sampled in 2007 during the groundwater synoptic sampling (see fig. 11). The entire Laurel Hill Creek Basin encompasses $125 \mathrm{mi}^{2}$ that drain into the Casselman River. At the gage at Ursina, Pa., the drainage area is $121 \mathrm{mi}^{2}$.
The streamflow data computed for the Ursina, Pa., streamflowgaging station from Jan. 1, 1991, through September 30, 2007, were used to calibrate the GSFLOW model. Daily values from the Ursina streamflow record were retrieved and used as the observed values for the model. The GSFLOW model was run on a daily time step. Stormflow simulation was not necessary for this model because daily values of streamflow were adequate for the model calibration process.

\section{MODFLOW Overview}

The finite-difference computer code MODFLOWNWT (Niswonger and others, 2011) was used to simulate steady-state groundwater flow in the Laurel Hill Creek Basin. MODFLOW-NWT is a code based on MODFLOW-2005 (Harbaugh, 2005), but it has better capabilities for solving the groundwater-flow equation for highly nonlinear problems. A graphical user interface linked to Argus Numerical Environments was used for pre- and post-processing of data (Winston, 2000). Input datasets to MODFLOW-NWT describe the hydrogeologic units of the basin, unsaturated zone, boundary conditions, water use, initial conditions, and hydraulic properties. GSFLOW then calculates hydraulic heads at discrete points (nodes in a model cell) and flows within the model domain (Ely and Kahle, 2012). For the Laurel Hill Creek Basin, there were a limited number of discrete points available for calibration during the model calibration period due to the availability of a small number of water-level measurements for groundwater wells.

\section{PRMS Overview}

PRMS is a modular, deterministic, distributed-parameter, physical-process basin model used to simulate and evaluate the effects of various combinations of precipitation, climate, and land use on basin response (Markstrom and others, 2008). A response to precipitation and hydrologic characteristics that route water through the basin is a function of the temporal and spatial variability of hydrologic parameters, water sources and sinks, and storage in a basin. Simulated results include waterbalance, snow dynamics, streamflow, surface runoff, interflow, and groundwater recharge. PRMS distributes water from the top of the plant canopy to the bottom of the soil zone on the basis of physical characteristics of the landscape and the interaction of these characteristics with hydrologic processes. Physical characteristics of the landscape need to be defined in PRMS, along with climatic variables that dictate the movement of precipitated water through the top layer of the system, defined here as the plant canopy down to the rooting zone. The PRMS model is partitioned into specific modules that are linked together in the model to move water through the system. These modules are designed to compartmentalize the basin into a series of interconnected reservoirs (fig. 13).

The soil-zone reservoir is divided into three finitevolume reservoirs: the capillary reservoir, gravity reservoir, 
and preferential-flow reservoir. These finite-volume reservoirs were developed in PRMS to allow for saturation excess in the soil zone to become Dunnian surface runoff. Dunnian surface runoff is surface runoff that occurs when soil saturation is exceeded (Markstrom and others, 2008). The capillary reservoir represents water held in the soil by capillary forces between the wilting and field-capacity thresholds. Water is removed from the reservoir by evaporation and transpiration, or the water can flow to the gravity reservoir. The gravity reservoir represents water in the soil zone between fieldcapacity and saturation thresholds that is not subject to the preferential-flow threshold. The gravity reservoir is capable of receiving groundwater discharge into the soil zone whenever the groundwater head in a connected finite-difference cell is greater than the soil-zone base. Gravity drainage is added to the groundwater reservoir in PRMS when using the PRMSonly mode in GSFLOW, whereas for the coupled model, the gravity drainage goes to MODFLOW finite-difference cells. The groundwater reservoir in PRMS can discharge water only to a stream, a downslope groundwater reservoir, and (or) a groundwater sink. Thus, the gravity reservoir is not capable of receiving groundwater discharge when using the PRMS-only mode. Water in the gravity reservoir is available for downslope flow (slow interflow) within the soil zone.

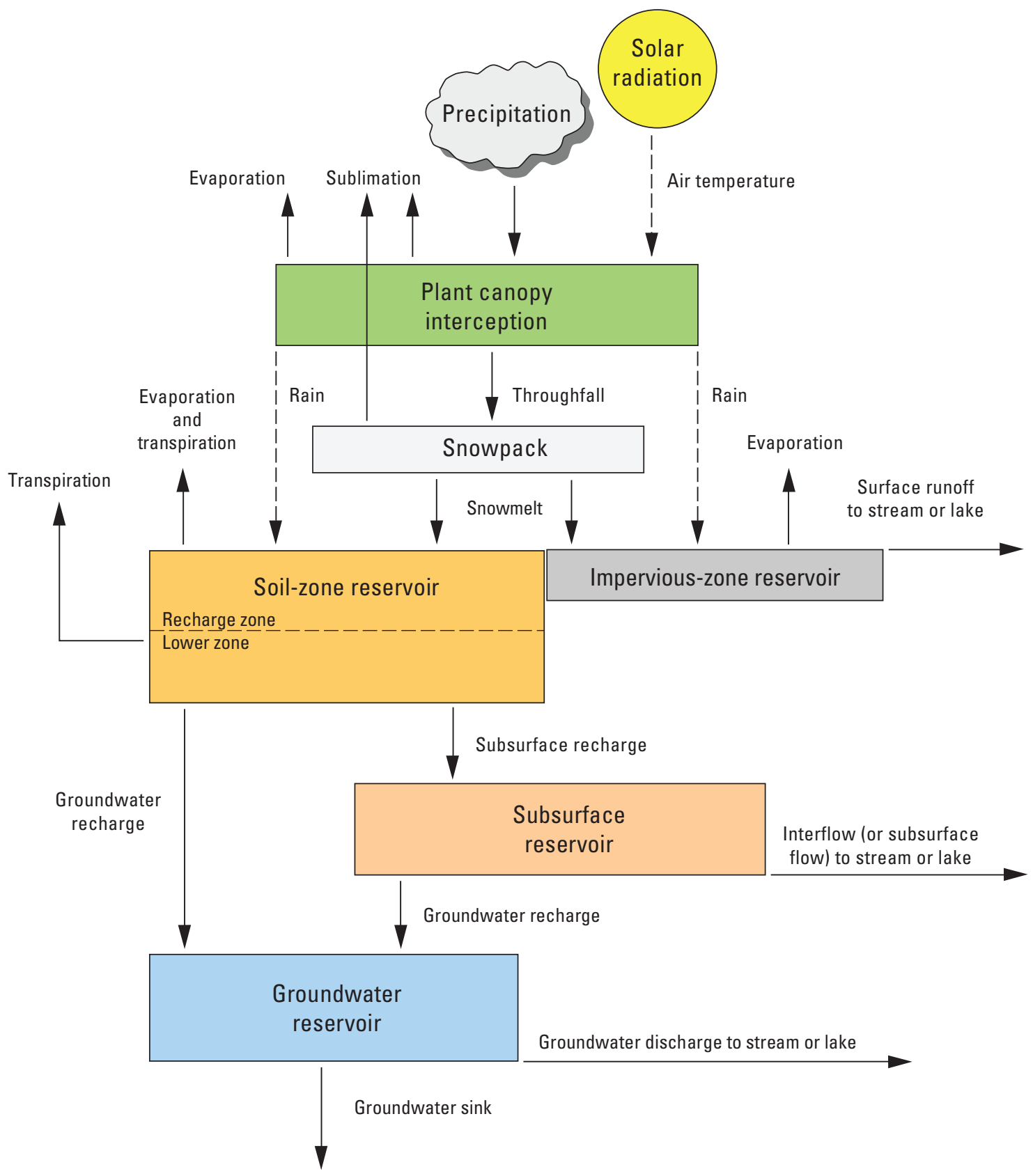

Figure 13. The Precipitation-Runoff Modeling System. (Modified from Leavesley and others, 1983) 
The preferential-flow reservoir represents soil water between field capacity and saturation that is available for fast interflow through relatively large openings in the soil of each Hydrologic Response Unit (HRU) (Markstrom and others, 2008). Saturation excess in the preferential flow reservoir is available for Dunnian runoff. The soil-zone reservoir is the reservoir from which fast and slow interflow occur; this reservoir also provides recharge to the groundwater reservoir. Water that is not stored in the groundwater reservoir either is discharged to a stream or lake or goes to a groundwater sink. For the Laurel Hill Creek model, no water was diverted to either a groundwater sink or a lake.

Different modules are available within PRMS to parameterize the model (Markstrom and others, 2008). The modules selected primarily depend on the data available for input and the specific purpose for which the model is constructed.

\section{Basin Delineation}

The boundaries of the basin used for PRMS model development were defined by overlaying the actual basin boundary, generated by the USGS StreamStats program (U.S. Geological Survey, 2012) as defined by topographic characteristics, with the MODFLOW grid. This created an irregular, jagged basin boundary because it was essential that the PRMS and MODFLOW boundaries align for the coupled model. MODFLOW cells were $150 \mathrm{~m}$ by $150 \mathrm{~m}$ in size; smoothing the boundary to match the actual basin boundary was not an option. Aligning the PRMS boundary with the MODFLOW boundary gave a total watershed area of 79,567.34 acres $\left(127.3 \mathrm{mi}^{2}\right)$, a size that exceeded the actual watershed area by $2 \mathrm{mi}^{2}$.

\section{Digital Elevation Model}

A digital elevation model (DEM) was generated for use in the PRMS model using the 30-m grid USGS National Elevation Dataset (NED) (U.S. Geological Survey, 2009b). The DEM was enhanced by overlaying the $30-\mathrm{m}$ grid on a10-m grid, then processed using methods described by Viger and Leavesley (2007). The higher resolution elevation data were used to more accurately simulate runoff characteristics in the basin, better define slope and aspect parameters, and better determine the spatial distribution of form of precipitation for precipitation events that occurred when events could be either rain or snow.

\section{Stream Network}

Elevations were combined with the USGS National Hydrography Dataset (NHD) (U.S. Geological Survey, 2009a) to incorporate known stream locations into the DEM prior to establishing the modeled area in PRMS. The stream network that is created is broken into stream segments. The streamflow-routing package (SFR2) in MODFLOW creates stream reaches. Stream reaches are stream segments located within specific MODFLOW cells. There can be multiple stream reaches in any one MODFLOW cell, but each stream reach can be associated with only one MODFLOW cell.
These stream reaches are input to PRMS so that the stream network defined in PRMS is broken into reaches. Surface runoff and interflow generated in PRMS are added to stream reaches using a PRMS cascade module that routes water from upland areas to stream reaches. The stream network in PRMS included a buffered area around the stream to optimize the exchange of surface water and groundwater with the stream channel.

\section{Generation of Hydrologic Response Units}

PRMS simulations are based on physical laws, empirical relations, and associated parameters and attributes of the modeled area. Because these parameters vary spatially and temporally, each basin in a PRMS model is partitioned into a series of hydrologic response units (HRUs). The discretization can be based on hydrologic and physical characteristics such as drainage boundaries, land-surface elevation, slope, and aspect; plant type and cover; land use; distribution of precipitation, temperature, and solar radiation; soil morphology and geology; and flow direction. Each HRU is assumed to be homogeneous with respect to these hydrologic and physical characteristics and to its hydrologic response. A water balance and an energy balance are computed daily for each HRU (Markstrom and others, 2008). For the Laurel Hill Creek Basin, the geographic information system (GIS) Weasel created by Viger and Leavesley (2007) was used to delineate two-plane HRUs throughout the basin. The DEM is input to the GIS Weasel, and the Weasel delineates a drainage network on the basis of the elevation of the Area of Interest (Viger and Leavesley, 2007). The GIS Weasel software uses a graphical user interface built upon a computing platform of Workstation Arcinfo GIS (ESRI Inc., 2001). The two-plane approach creates HRUs on either side of a stream segment, and upland areas that drain to the downgradient HRUs are separate from the HRUs delineated along stream channels. The area immediately adjacent to the stream was designated as a separate HRU. These HRUs immediately along the stream channel were defined as stream-buffer HRUs and varied in width (from the center line of the stream) from 0 to 200 meters. In general, HRU generation for the basin was dictated primarily by the drainage network. Other physical characteristics that were incorporated into HRU development were changes in slope and land use. Once the physical boundaries of the HRUs are finalized in the GIS Weasel, these characteristics are numerically defined in the PRMS parameter file.

\section{Climate and Streamflow Data}

Daily values for climate and streamflow are input to PRMS in a file called the PRMS data file. Climatic data input to PRMS must include maximum and minimum air temperatures, precipitation amounts, and solar radiation data. Pan evaporation data can also be input, but this was not included for the Laurel Hill Creek Basin model. The climate data for the closest available continuous recording stations should be input to the model. Large gaps of missing data can be 
problematic, so it is necessary to screen the climate data so that stations with more than 10 percent of missing daily values are excluded from the input data file. Solar radiation data are typically limited, so the best approach is to use the nearest airport location that has daily solar radiation data available. For both precipitation and temperature data, three different modules are available to distribute temperatures and precipitation across the basin that is being modeled.

Daily observed values for streamflow need to be entered into the PRMS data file so that the modeled results can be compared to actual data. There should be no missing data in the streamflow record. Data from more than one streamflow station can be input to PRMS, and simulations can be generated for comparison to these various stations; however, for the Laurel Hill Creek Basin, only one streamflow-gaging station was used (USGS station 03080000 Laurel Hill Creek at Ursina, Pa.).

\section{Model Parameterization}

Parameters input to PRMS are necessary in order to derive simulated values for streamflow. The number of values for each parameter is dictated by the dimension of that particular parameter. Dimensions define the number of spatial features and constants, such as the number of HRUs, number of months in a year, and the number of temperature stations (Markstrom and others, 2008). Some dimensions are one array; others are two arrays. For example, the parameter summer canopy density is a one-dimensional array that has one value for each HRU. The dimension for summer canopy density is nhru. An example of a two-dimensional array is a precipitation parameter (rain_mon) that has monthly values and is distributed across each HRU. This two-dimensional parameter has 12 values for each HRU (nmonth x nhru).

PRMS has distributed and non-distributed parameters (Ely and Kahle, 2012). Distributed parameters are attributed to each HRU and describe physiographic characteristics, such as area, slope, canopy density, and soil characteristics. Other distributed parameters are those that describe hydrologic processes such as subsurface flow and climatic variables that can be adjusted by HRU on the basis of physical characteristics of the HRU. Non-distributed parameters are parameters held constant throughout the basin (these parameters have a dimension equal to one), such as the parameter tmax_allsnow, which is defined as the "monthly maximum air temperature at which precipitation is all snow" (Markstorm and others, 2008).

Parameters with discrete spatial features that have distinct values for each HRU were derived by compiling geospatial databases for the basin, then applying tools in ARCMAP 9.2 (ESRI Inc., 2009) to spatially distribute the data by HRU. The types of geospatial data that were input include those physiographic characteristics listed above, plus others such as vegetative-cover type, land use, and aspect. Land-use and vegetative-cover-type data were derived from the 2001 National
Land Cover Database (Multi-Resolution Land Characteristics Consortium 2001). Soil characteristics were compiled from the SSURGO database for the three different counties that encompass the basin: Somerset, Westmoreland, and Fayette (U.S. Department of Agriculture, Natural Resource Conservation Service, 2004a, 2004b, 2006). The hydrology and elevation datasets were described previously. Once distributed to each HRU, the geospatial data from these various datasets were reclassified, when necessary, to conform to acceptable ranges that are needed to run the PRMS model. Various techniques were used for the reclassification with some of the details for this described in Viger and Leavesley (2007). Viger and Leavesley (2007) developed the GIS Weasel to aid in the preparation of spatial data for input to hydrologic models. The GIS Weasel was used for this study to generate parameter values. It was also used as a guide for parameterization derived by other methods. All parameters used in the PRMS only mode of the GSFLOW model are described in Markstrom and others (2008); much of this information was derived initially from the original PRMS manual (Leavesley and others, 1983).

\section{GSFLOW Coupling of PRMS and MODFLOW}

After flow models for PRMS and MODFLOW had been calibrated separately (uncoupled), GSFLOW was used to couple the two models. The GSFLOW model can be run in three different modes: PRMS only, MODFLOW only, and a coupled model. The version of GSFLOW used for the Laurel Hill Creek model was run in the PRMS- and MODFLOWonly modes until PRMS and MODFLOW were calibrated to observed conditions.

Prior to coupling the PRMS and MODFLOW models, a recharge array from PRMS was output and used as input to the MODFLOW model. The models were then coupled. A critical aspect of the coupled model is the linking of the HRUs developed for PRMS with the finite-difference cells in MODFLOW. This linkage is primarily done through the application of gravity reservoirs that transfer water from the HRUs to the finitedifference cells (Markstrom and others, 2008). Once coupled, the PRMS groundwater reservoir is replaced by MODFLOW components.

The movement of water from PRMS HRUs to finitedifference cells is simulated in the Unsaturated-Zone Flow (UZF) Package within MODFLOW (Niswonger and others, 2006). Flow in the unsaturated zone beneath the soil zone and water bodies is based on a one-dimensional kinematic wave approximation. Above the soil and water body zone, hydrologic processes are defined by PRMS. Once the water is routed through the unsaturated zone, hydrologic processes are defined by MODFLOW. It is worth noting that the simulated routing of water in the coupled GSFLOW model is conducted through the Streamflow Routing Package within MODFLOW (Niswonger and Prudic, 2005). 


\section{Characterization of Water Quality and Quantity}

The quality and quantity of water in the Laurel Hill Creek Basin were characterized for low-flow conditions in 2007 and compared to criteria for HQ-CWF waters. Physical attributes of the basin were acquired and stored into GIS layers for the basin. All the water-quality data collected for this project in 2007, along with the stream temperature data collected from 2007-10, are available at the USGS National Water Information System (NWIS) website (http://dx.doi.org/10.5066/ F7P55KJN). In addition, hydrologic (primarily from the continuous streamflow-gaging station on Laurel Hill Creek at Ursina, Pa.) and water-use data available for the basin were compiled. The field data, GIS data, and water data were used to develop a GSFLOW model for the entire basin.

\section{Water Quality}

The PaDEP has published specific chemical and thermal criteria for a HQ-CWF. To meet HQ-CWF criteria, the stream temperature must not exceed a maximum of $3.3^{\circ} \mathrm{C}$ for January and February to $18.9^{\circ} \mathrm{C}$ for July and August (appendix 2), the DO concentration must be greater than or equal to $5.0 \mathrm{mg} / \mathrm{L}$, the $\mathrm{pH}$ must be 6.0 to 9.0 inclusive, and the concentration of ammonia must not exceed established toxicity thresholds (Commonwealth of Pennsylvania, 2009). The EPA (2015a) has also published nationally recommended water-quality criteria for aquatic life that are somewhat broader in range and include more constituents than the PaDEP criteria. The EPA waterquality criteria give a range of concentrations, based on acute and chronic impacts to aquatic life. Chronic impacts to aquatic life can occur if $\mathrm{pH}$ is less than 6.5 or greater than 9.0, if $\mathrm{Al}$ (given a $\mathrm{pH}$ range of 6.5-9.0) exceeds $87 \mu \mathrm{g} / \mathrm{L}$, if $\mathrm{Cl}$ exceeds $230 \mathrm{mg} / \mathrm{L}$, or if Fe exceeds $1,000 \mu \mathrm{g} / \mathrm{L}$. Additionally, nutrient water-quality criteria proposed by the EPA (2000) for streams in Ecoregion XI (Central and Eastern Forested Uplands), which includes the Laurel Highlands, could be applicable to minimize nutrient enrichment and eutrophication. The proposed nutrient criteria for total $\mathrm{N}$ and total $\mathrm{P}$ are $0.31 \mathrm{mg} / \mathrm{L}$ and $0.01 \mathrm{mg} / \mathrm{L}$, respectively, for streams (U.S. Environmental Protection Agency, 2000).

Human water use in the basin necessitates withdrawals from groundwater and surface-water sources; therefore, the water chemistry of both groundwater and surface water is an important attribute of water for human consumption, for which drinking water standards could be relevant. The EPA (2012) has published drinking water standards for maximum contaminant levels (MCLs) and SMCLs for many constituents relevant to this study. MCLs have been established for As $(4 \mu \mathrm{g} / \mathrm{L})$, $\mathrm{NO}_{3}(10 \mathrm{mg} / \mathrm{L}$ as $\mathrm{N})$, and $\mathrm{NO}_{2}(1 \mathrm{mg} / \mathrm{L}$ as $\mathrm{N})$. SMCLs have been established for $\mathrm{Al}(50$ to $200 \mu \mathrm{g} / \mathrm{L}), \mathrm{Cl}(250 \mathrm{mg} / \mathrm{L}), \mathrm{Fe}$ $(300 \mu \mathrm{g} / \mathrm{L}), \mathrm{Mn}(50 \mu \mathrm{g} / \mathrm{L}), \mathrm{pH}$ (6.5 to 8.5 inclusive), and $\mathrm{SO}_{4}$ $(250 \mathrm{mg} / \mathrm{L})$. The MCL for $\mathrm{NO}_{3}$ and the SMCLs for $\mathrm{Cl}, \mathrm{Fe}$, and $\mathrm{SO}_{4}$ are exactly the same as the levels established by the Commonwealth of Pennsylvania (2009) for potable water supplies (PWS). The Mn level for a PWS in Pennsylvania is $1,000 \mu \mathrm{g} / \mathrm{L}$.

\section{Chemistry of Surface Water}

Results of analyses of surface-water samples collected in summer and fall 2007 indicate that low-flow water quality was affected by land-use practices and by geologic and hydrologic factors. Due to the proximity to various sources or activities that affect water quality on the local scale, tributaries usually showed a wider range of constituent values than the main stem of Laurel Hill Creek.

The chemical criteria published by PaDEP indicated that only one main-stem site did not meet the criteria for a HQ-CWF. The uppermost site sampled in the main stem (LHC-1st, station 03079320) had a measured DO of $3.4 \mathrm{mg} / \mathrm{L}$, which is below the $5.0 \mathrm{mg} / \mathrm{L}$ minimum criteria for DO concentrations. This station also had the highest measured ammonia$\mathrm{N}$ concentration $(0.192 \mathrm{mg} / \mathrm{L})$ for all sites sampled, but this met the ammonia criteria as established by PaDEP (Commonwealth of Pennsylvania, 2009). All the main-stem sites met the EPA guidelines for nationally recommended water-quality criteria.

Total-N concentrations in the main stem ranged from 0.35 to $1.42 \mathrm{mg} / \mathrm{L}$ (fig. 14 , appendix 1), with highest values associated with agricultural land use in the northeastern part of the basin. Thus, all the main stem samples exceeded the relevant nutrient criterion for total $\mathrm{N}$ concentration of $0.31 \mathrm{mg} / \mathrm{L}$ in streams (U.S. Environmental Protection Agency, 2000). The data show that total $\mathrm{N}$ concentrations for the main stem are highest in the upper part of the basin. The highest total $\mathrm{N}$ concentration $(1.42 \mathrm{mg} / \mathrm{L})$ for the main stem was measured at LHC-1st (station 03079320) (fig. 14; appendix 1); the second highest $(1.2 \mathrm{mg} / \mathrm{L})$ and third highest $(1.17 \mathrm{mg} / \mathrm{L})$ concentrations of total N were measured at LHC-A3 (station 03079550) (fig. 8), also in the upper part of the basin. The total P concentrations along the main stem ranged from $0.01 \mathrm{mg} / \mathrm{L}$ (in some cases, less than $(<) 0.02$ ) to $0.06 \mathrm{mg} / \mathrm{L}$ (appendix 1). The highest total $\mathrm{P}$ concentration $(0.06 \mathrm{mg} / \mathrm{L})$ measured along the main stem was also at LHC-1st (station 03079320). All samples in the upper reaches of the main stem had total $\mathrm{P}$ concentrations of 0.01 or greater, which exceeded or equaled the nutrient criteria of $0.01 \mathrm{mg} / \mathrm{L}$ in streams (U.S. Environmental Protection Agency, 2000). Water-quality data collected for the Rivers Conservation Plan (RCP) in 2003 also showed the highest nutrient concentrations in the main stem in the upper part of the basin (Crouse \& Company of Somerset and Kleinschmidt Group, 2005). These results are, in general, consistent with the PaDEP (2011) designation of the upper section of the main stem on the 303(d) list of impaired stream segments in Pennsylvania.

The only constituent measured for surface-water samples collected in the main stem of Laurel Hill Creek that had values exceeding the EPA MCL, EPA SMCL, or PaDEP PWS 

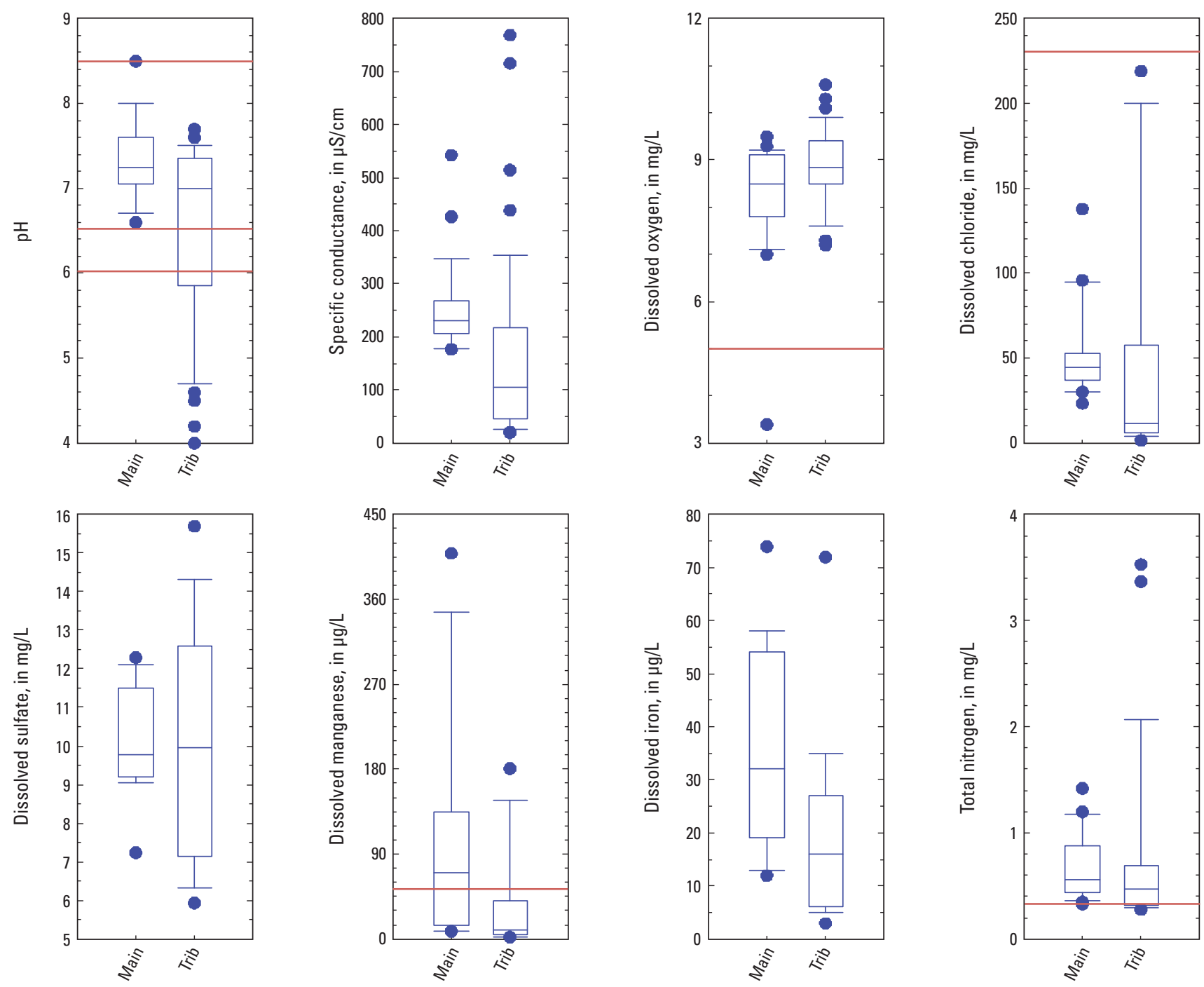

EXPLANATION

- Outlier

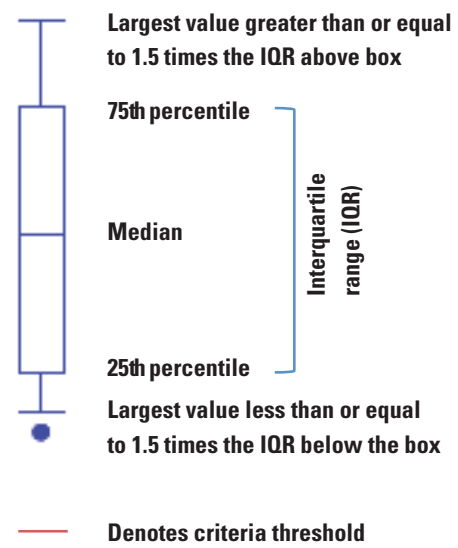

Figure 14. Distribution of selected water-quality constituents in surface-water samples collected at main stem and tributary sites in the Laurel Hill Creek Basin, southwestern, Pennsylvania, 2007. ( $\mu \mathrm{S} / \mathrm{cm}$, microsiemens per centimeter at 25 degrees Celsius; $\mathrm{mg} / \mathrm{L}$, milligrams per liter; $\mu \mathrm{g} / \mathrm{L}$, micrograms per liter; Main, main stem of Laurel Hill Creek; Trib, tributary stream to Laurel Hill Creek) 
criteria was Mn (fig. 14). Concentrations of Mn greater than the SMCL can cause black oxide staining of ceramic plumbing fixtures and other light-colored materials. Fifty-six percent of the Mn samples collected in the main stem exceeded the SMCL of $50 \mu \mathrm{g} / \mathrm{L}$. The highest Mn concentration was measured at LHC-1st ( $409 \mu \mathrm{g} / \mathrm{L})$, which is the upper-most site sampled on the main stem. Mn concentrations gradually decreased along the main stem with mean concentrations at LHC-U (the furthest downstream site) about $14 \mu \mathrm{g} / \mathrm{L}$ (appendix 1).

The chemical criteria published by PaDEP indicate that some of the tributary sites did not meet the criteria of a HQ$\mathrm{CWF}$. The values for seven tributaries had $\mathrm{pH}$ values less than the 6.0 criteria (appendix 1). These tributaries were generally located in the western half of the basin in drainage areas that are completely forested. All tributary sites did meet the PaDEP CWF criteria, based on DO and ammonia concentrations. An additional three tributaries had $\mathrm{pH}$ values between 6.0 and 6.5 (appendix 1), indicating that these tributaries did not meet the EPA criteria for aquatic life. All tributaries sampled met the EPA aquatic criteria pertaining to $\mathrm{Al}, \mathrm{Cl}$, and $\mathrm{Fe}$.

Nutrient concentrations for some tributary sites in the Laurel Hill Creek Basin also exceeded the relevant nutrient criteria (fig. 14), with the highest concentrations in samples downstream from wastewater discharges. The highest total $\mathrm{N}$ for tributary sites was measured at station 03079480 on Kooser Run (3.31 and $3.46 \mathrm{mg} / \mathrm{L}$ ) (appendix 1), and is more than 10 times greater than the relevant total $\mathrm{N}$ nutrient criteria (U.S. Environmental Protection Agency, 2000). A wastewater treatment facility, along with a fish hatchery in the upper part of Kooser Run subbasin, could be the sources of the elevated $\mathrm{N}$. The only other tributary subbasin with a measured total $\mathrm{N}$ concentration greater than $1 \mathrm{mg} / \mathrm{L}$ was Lost Creek (station 03079740) with a measured total N concentration of $2.07 \mathrm{mg} / \mathrm{L}$ in June 2007. A campground located in the Lost Creek Basin discharges treated wastewater into the creek upstream from the sampling site. The concentration of total P measured for Lost Creek $(0.11 \mathrm{mg} / \mathrm{L})$ in June 2007 was the highest measured total-P concentration in the entire Laurel Hill Creek Basin (appendix 1) and was also more than 10 times greater than the relevant total P nutrient criteria (U.S. Environmental Protection Agency, 2000). Kooser Run and Lost Creek also were found to have relatively high nutrient concentrations for samples collected for the RCP (Crouse \& Company of Somerset and Kleinschmidt Group, 2005). Note that Crab Run (station 03079350) (fig. 8), a tributary in the upper part of Laurel Hill Creek Basin within an area of concentrated agricultural activity, was not sampled for nutrients because of inaccessibility.

None of the tributaries exceeded any MCLs for the constituents sampled, but SMCLs were exceeded for many tributary sites. As stated earlier, 10 tributary sites were below the EPA water-quality criteria for $\mathrm{pH}$ of 6.5. The lower $\mathrm{pH}$ limit for the SMCL is also 6.5. Three of the 16 samples collected at tributary sites had Mn concentrations greater than the SMCL of $50 \mu \mathrm{g} / \mathrm{L}$. Two of these samples that exceeded the SMCL for Mn (181 and $147 \mu \mathrm{g} / \mathrm{L})$ were collected at Cranberry Glade Run (station 03079480). This tributary drains a boggy lake and had measured $\mathrm{pH}$ values of 4.5 and 4.8. Low DO conditions such as those in a boggy lake help to extract Mn from organic-rich sediments; in addition, Mn solubility increases with decreasing $\mathrm{pH}(\mathrm{Hem}, 1985)$. The low $\mathrm{pH}$ of Cranberry Glade Run directly contributed to the elevated Al concentrations of 442 and $476 \mu \mathrm{g} / \mathrm{L}$. This site was the only tributary to exceed the SMCL for Al of $200 \mu \mathrm{g} / \mathrm{L}$ (appendix 1). None of the tributary sites exceeded the levels established by the Commonwealth of Pennsylvania (2009) for PWS.

Even though $\mathrm{Cl}$ concentrations were below the waterquality and PWS criteria established by the EPA and the Commonwealth of Pennsylvania, $\mathrm{Cl}$ concentrations in the upper parts of the basin were elevated in one tributary sampled and the main stem. The highest $\mathrm{Cl}$ concentrations in the Laurel Hill Creek Basin were measured in a tributary subbasin. Two surface-water sites sampled, Clear Run (station 03079400) and Crab Run (station 03079350), are transected by the Pennsylvania Turnpike (I-76) where they flow in a general north to south direction and feed into the main stem of Laurel Hill Creek (fig. 8). Concentrations of $\mathrm{Cl}$ for Clear Run (station 03079400) below I-76 were 219 and 200 mg/L for samples collected in June and September 2007, respectively (fig. 15; appendix 1). The $\mathrm{Cl}$ concentration measured in Clear Run for the RCP was $190 \mathrm{mg} / \mathrm{L}$ (Crouse \& Company of Somerset and Kleinschmidt Group, 2005). The corresponding sodium (Na) concentration of $118 \mathrm{mg} / \mathrm{L}$ in June 2007 and SC values of 769 and 716 microsiemens per centimeter at 25 degrees Celsius $(\mu \mathrm{S} / \mathrm{cm})$ for Clear Run in June and September 2007 also were higher than for any other sites sampled (appendix 1). Samples for $\mathrm{Cl}$ and $\mathrm{Na}$ were not collected at Crab Run (station 03079350), but the SC for Crab Run was measured at $515 \mu \mathrm{S} / \mathrm{cm}$ at $25^{\circ} \mathrm{C}$ (fourth highest $\mathrm{SC}$ measured in the Laurel Hill Creek Basin) (appendix 1). The high values for $\mathrm{SC}$ in these tributaries contributed to the high values recorded downstream along the main stem (fig. 16). The highest mean $\mathrm{Cl}(117 \mathrm{mg} / \mathrm{L}), \mathrm{Na}(77 \mathrm{mg} / \mathrm{L})$, and SC values $\left(485 \mu \mathrm{S} / \mathrm{cm}\right.$ at $\left.25^{\circ} \mathrm{C}\right)$ recorded in the main stem were for the site (LHC-A0-2, station 03079420) immediately below the confluence with Clear Run. The likely cause of the elevated $\mathrm{Cl}, \mathrm{Na}$, and $\mathrm{SC}$ values is the application of road deicing salts $(\mathrm{NaCl})$ on I-76. Deicing materials have been documented as causes of elevated concentrations of dissolved salts in shallow groundwater and soils (Jones and Sroka, 1997); eventually, the salt constituents can run off the roadway to the surface-water system. The influx of $\mathrm{Cl}$, $\mathrm{Na}$, and other dissolved constituents in the upper parts of the basin causes a gradient of higher to lower values for specific conductance moving downstream through the basin until Laurel Hill Creek discharges into the Casselman River. The lowest mean SC $\left(186 \mu \mathrm{S} / \mathrm{cm}\right.$ at $\left.25^{\circ} \mathrm{C}\right)$ value for the main stem occurred at LHC-U (station 03080000), the farthest downstream sampling site (fig. 8). The lowest mean $\mathrm{Cl}$ concentrations for the main stem downstream from the confluence of Clear Run and Laurel Hill Creek occurred at the three farthest 


\section{EXPLANATION}

Clear Run $\mathrm{Cl}=209.5 \mathrm{mg} / \mathrm{L}$ $\mathrm{Na}=118 \mathrm{mg} / \mathrm{L}$
Surface-water site with site identifier and mean chloride (Cl) and sodium ( $\mathrm{Na}$ ) concentrations in milligrams per liter (mg/L)

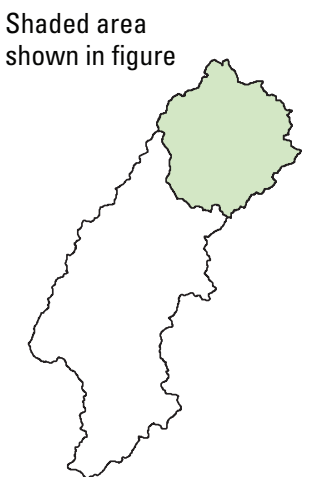

Laurel Hill Creek Basin

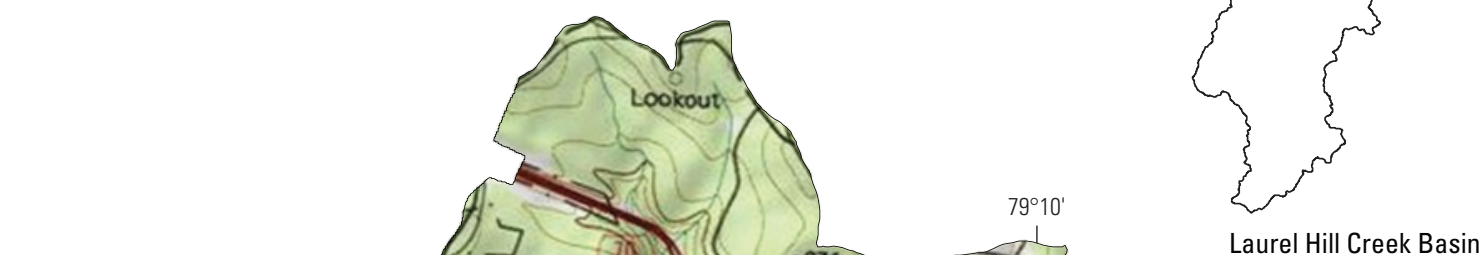

Base from U.S. Geological Survey Bakersville, 1993, 1:24,000 and Seven Springs, 1993, 1:24,000

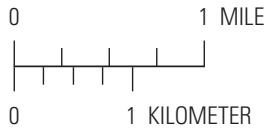

Figure 15. Chloride and sodium concentrations measured in the upper part of the Laurel Hill Creek Basin, southwestern, Pennsylvania, 2007. 


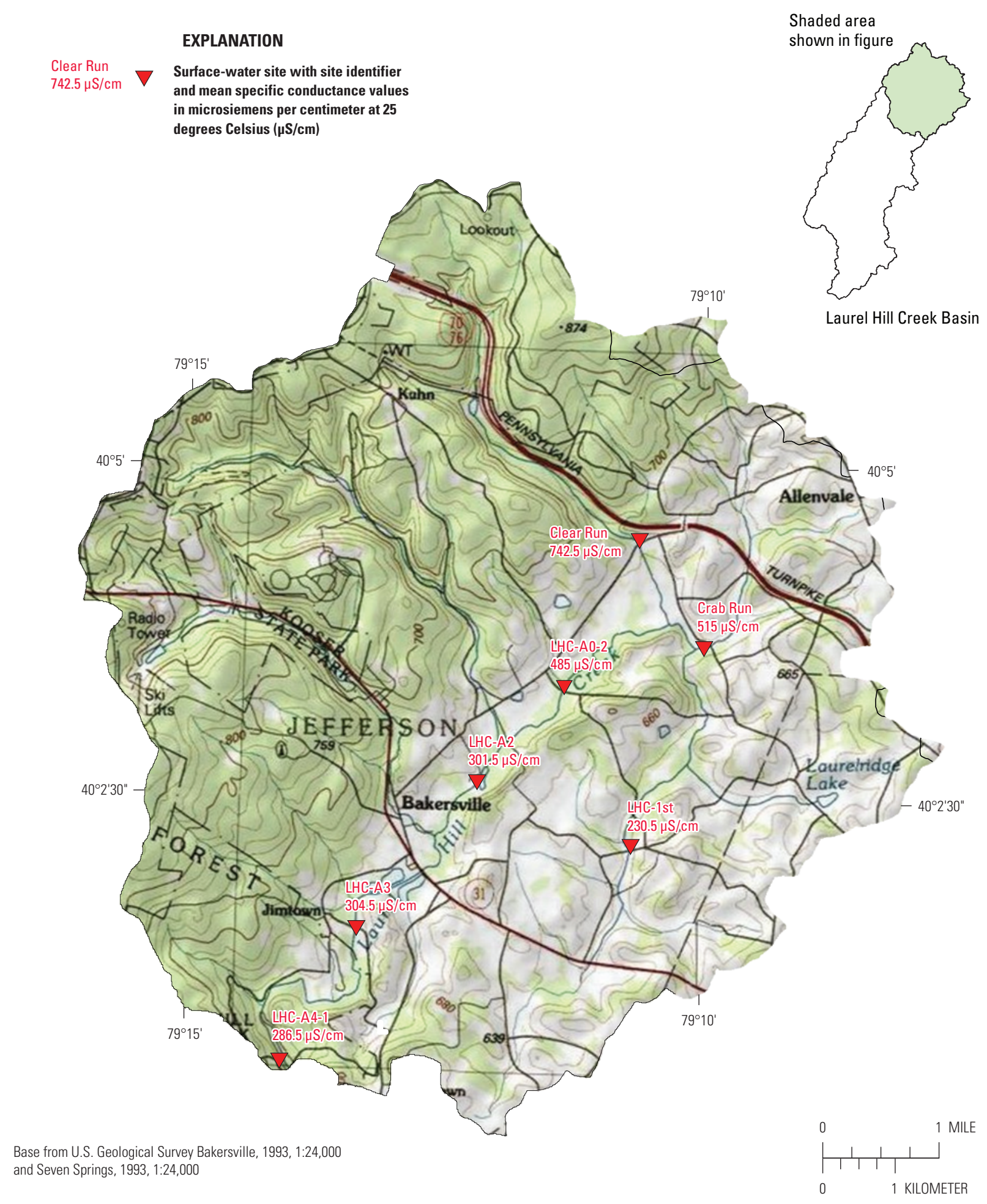

Figure 16. Specific conductance values measured in the upper part of the Laurel Hill Creek Basin, southwestern, Pennsylvania, 2007. 
downstream sampling sites, LHC-A8 (station 03079942), LHC-A9 (station 03079993), and LHC-U (station 03080000) (fig. 8), with $\mathrm{Cl}$ concentrations at these sites ranging from 34.45 to $35.1 \mathrm{mg} / \mathrm{L}$ (appendix 1). The lowest $\mathrm{Cl}, \mathrm{Na}$, and $\mathrm{SC}$ values measured in the basin were for tributary subbasins not affected by road runoff. Eight tributary sites had Cl concentrations of less than $(<) 10 \mathrm{mg} / \mathrm{L}$ (fig. 14). The lowest $\mathrm{SC}$ values were measured at tributary sites Buck Run (station 03079580, $20 \mu \mathrm{S} / \mathrm{cm}$ at $25^{\circ} \mathrm{C}$ ), Garys Run (station 03079700, $26 \mu \mathrm{S} / \mathrm{cm}$ at $25^{\circ} \mathrm{C}$ ), and Cole Run (station 03079704, $26 \mu \mathrm{S} / \mathrm{cm}$ at $\left.25^{\circ} \mathrm{C}\right)$. These sites are in the central part of the basin and drain forest-covered ridges along the western boundary (fig. 8).

The signature of geologic formations on water quality is apparent only for the Laurel Hill Creek Basin tributary sites because various units contribute water to the main stem of Laurel Hill Creek. Sharpe and others (1984) showed that acidic $\mathrm{pH}$ values were common along Laurel Hill owing to inputs of acidic precipitation along with the poor buffer capacity of certain geologic units. The lowest $\mathrm{pH}$ values in the basin were measured for tributary sites, namely Crise Run (station 03079540, 4.1), Cole Run (station 03079704, 4.6), and Gross Run (station 03079520, 4.95), which drain the forested western ridge and are underlain by the Allegheny Formation. Some tributary sites underlain by the Pottsville Formation had mean $\mathrm{pH}$ values of $<6.0$, including Cranberry Glade Run (station 03079900, 4.65) and Moore Run (station 030794464, 5.85). The low $\mathrm{pH}$ values for Cole and Cranberry Glade Runs were also measured in water-quality samples collected for the RCP report (Crouse \& Company of Somerset and Kleinschmidt Group, 2005). Note that the water-quality samples collected from Cranberry Glade Run were collected downstream from Cranberry Glade Lake. The main-stem sites sampled in 2007 had a range of mean $\mathrm{pH}$ values from 6.6 to 8.5 (appendix 1).

Specific conductance (SC) data for the Laurel Hill Creek Basin tributary sites varied in relation to geologic formation. The lowest SC values for tributary sites were measured for sites underlain by the Mauch Chunk and Pottsville Formations. The median SC values for samples collected in tributaries underlain by the Mauch Chunk and Pottsville Formations were 42 and $44 \mu \mathrm{S} / \mathrm{cm}$ at $25^{\circ} \mathrm{C}$, respectively; the median SC values for the Allegheny and Glenshaw Formations were 134 and $306 \mu \mathrm{S} / \mathrm{cm}$ at $25^{\circ} \mathrm{C}$, respectively. Tributary sites underlain by the Mauch Chunk Formation had lower concentrations for most of the constituents measured. Median concentrations for dissolved sulfate $\left(\mathrm{SO}_{4}\right)$, iron $\mathrm{Fe}$, and $\mathrm{Mn}$ were $6.1 \mathrm{mg} / \mathrm{L}$, $8.0 \mu \mathrm{g} / \mathrm{L}$, and $7.7 \mu \mathrm{g} / \mathrm{L}$, respectively, measured in samples from tributaries underlain by the Mauch Chunk Formation, whereas samples from tributaries underlain by the Allegheny Formation had median concentrations of dissolved $\mathrm{SO}_{4}, \mathrm{Fe}$, and $\mathrm{Mn}$ of $11.3 \mathrm{mg} / \mathrm{L}, 22 \mu \mathrm{g} / \mathrm{L}$, and $10 \mu \mathrm{g} / \mathrm{L}$, respectively. Samples from tributaries underlain by the Pottsville Formation had higher median values for dissolved $\mathrm{SO}_{4}$ and $\mathrm{Mn}$ than samples from tributaries underlain by the Mauch Chunk Formation (fig. 17).

\section{Temperature of Surface Water}

The stream temperatures measured during the waterquality synoptics indicated that the main stem had elevated stream temperatures relative to tributary sites. The stream temperature maximums for a $\mathrm{HQ}-\mathrm{CWF}$, based on PaDEP criteria, are 17.8 and $15.5^{\circ} \mathrm{C}$ for the synoptics conducted from June 25-27, 2007, and September 17-19, 2007, respectively. For the 12 main-stem sites sampled, only one (LHC-A0-2, station $03079420,17.6^{\circ} \mathrm{C}$ ) had a measured stream temperature below the $17.8^{\circ} \mathrm{C}$ maximum for the June synoptic, and nine mainstem sites were below the $15.5^{\circ} \mathrm{C}$ maximum for the September synoptic. For the tributary sites, 20 of the 24 sites sampled in June 2007 were below the $17.8^{\circ} \mathrm{C}$ maximum, and none of the 20 sites sampled in September 2007 exceeded the $15.5^{\circ} \mathrm{C}$ maximum (appendix 1). These data indicate that tributaries in the Laurel Hill Creek Basin meet the thermal criteria for a HQ-CWF in most instances, where as the main stem generally does not meet the thermal criteria. The caveat to the synoptic data is that they represent only instantaneous values.

The daily maximum stream temperatures at the five continuous record sites on the main stem of Laurel Hill Creek from 2007 to 2010 frequently exceeded the HQ-CWF temperature criteria maximum established by the Commonwealth of Pennsylvania (2009). All five sites exceeded the maximum temperature criteria for the summer months in each year. The average maximum temperatures in June ranged from $19.2^{\circ} \mathrm{C}$ to $22.0^{\circ} \mathrm{C}$; in July, $20.7^{\circ} \mathrm{C}$ to $25.5^{\circ} \mathrm{C}$; and in August, $20.7^{\circ} \mathrm{C}$ to $26.0^{\circ} \mathrm{C}$. The stream temperature maximums for a HQ-CWF, based on PaDEP criteria for June, July, and August, are $17.8,18.9$, and $18.9^{\circ} \mathrm{C}$, respectively. The lowest average maximums for these 3 months occurred at the two upper-most stations (03079420 and 03079550), and the highest average maximum occurred at the furthest downstream station (03080100). The five continuous record sites generally did not exceed the HQ-CWF temperature criteria established for the winter months. The percentage of months that exceeded the maximum temperature criteria was lowest for the site furthest upstream (46 percent) and highest for the site furthest downstream (69 percent) (appendix 2).

The network of stream-temperature probes indicated that temperature differences between sites were greater in warmer months than in colder months, with temperatures generally increasing in the downstream direction during warmer months (table 1; appendix 2). The data plotted for July 2008 and February 2009 (fig. 18) show the typical relation between the five stream-temperature monitoring sites. The farthest upstream site is station 03079420 (Laurel Hill Creek below Shanks Run near Bakersville, Pa.) and the farthest downstream site is station 03080100 (Laurel Hill Creek at Ursina, Pa.) (fig. 9). The overall mean stream temperature varied from 10.0 ${ }^{\circ} \mathrm{C}$ at station 03079550 (Laurel Hill Creek at Jimtown near Bakersville) to $12.3{ }^{\circ} \mathrm{C}$ for station 03080100 . For summer months, the means ranged from $19.1^{\circ} \mathrm{C}$ for station 03079420 to $21.5^{\circ} \mathrm{C}$ for station 03080100 (table 1). The highest maximum (instantaneous) stream temperatures recorded at the 

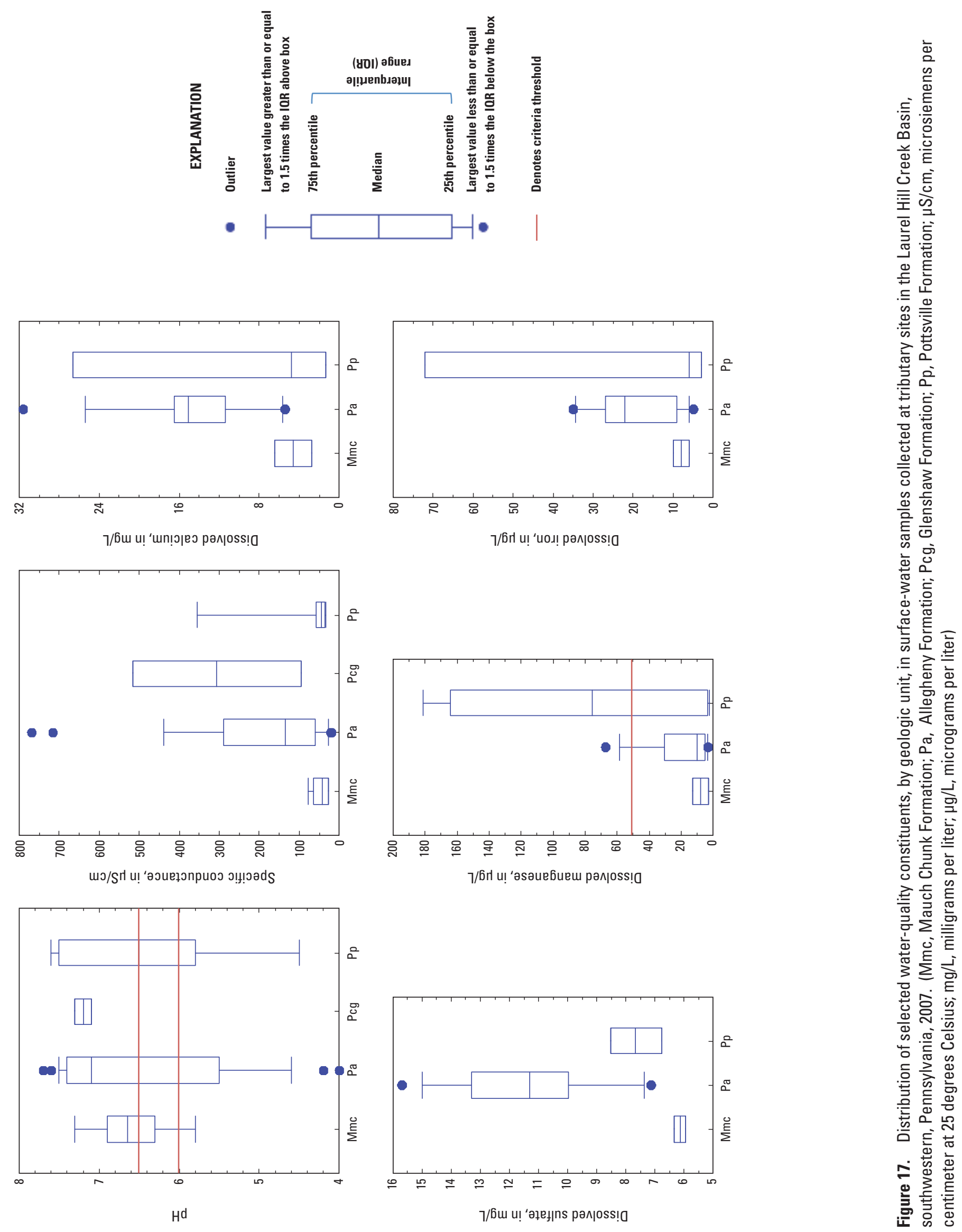


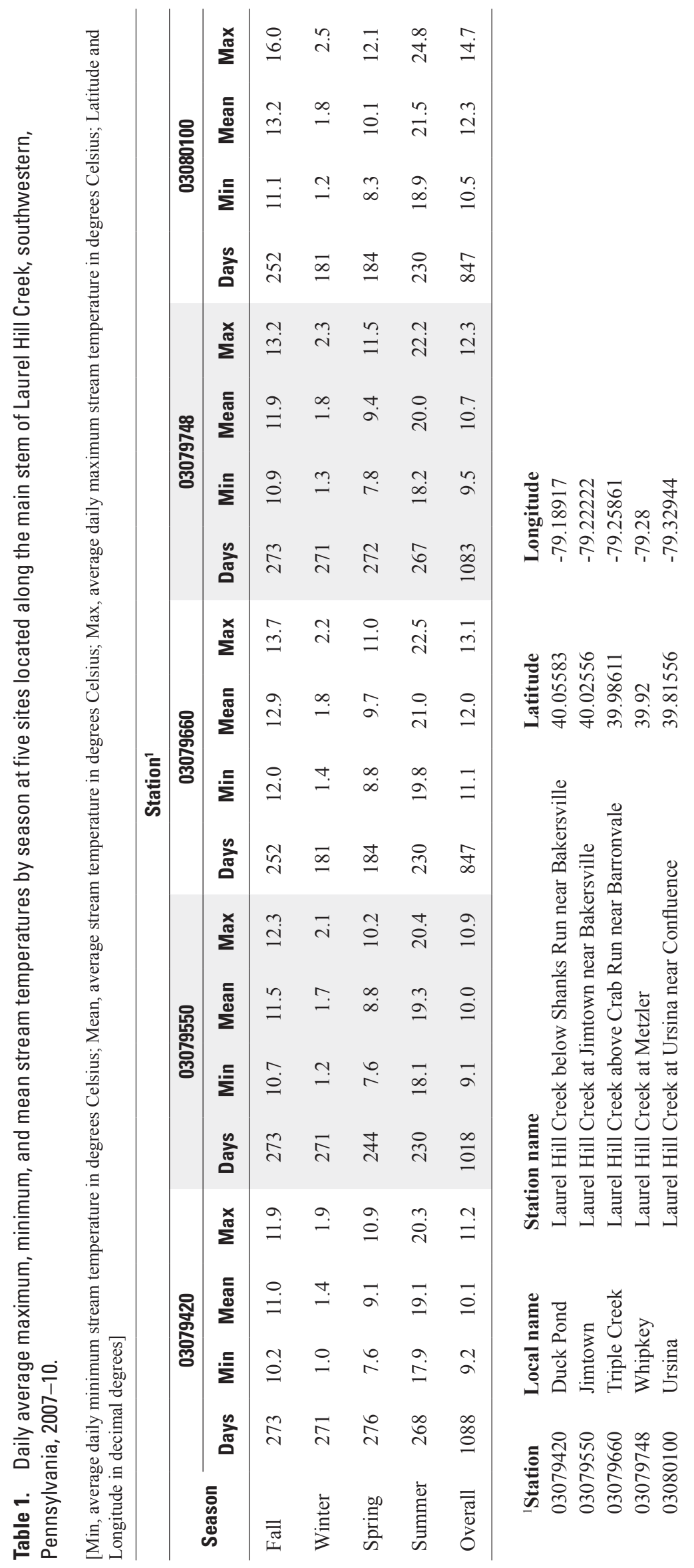



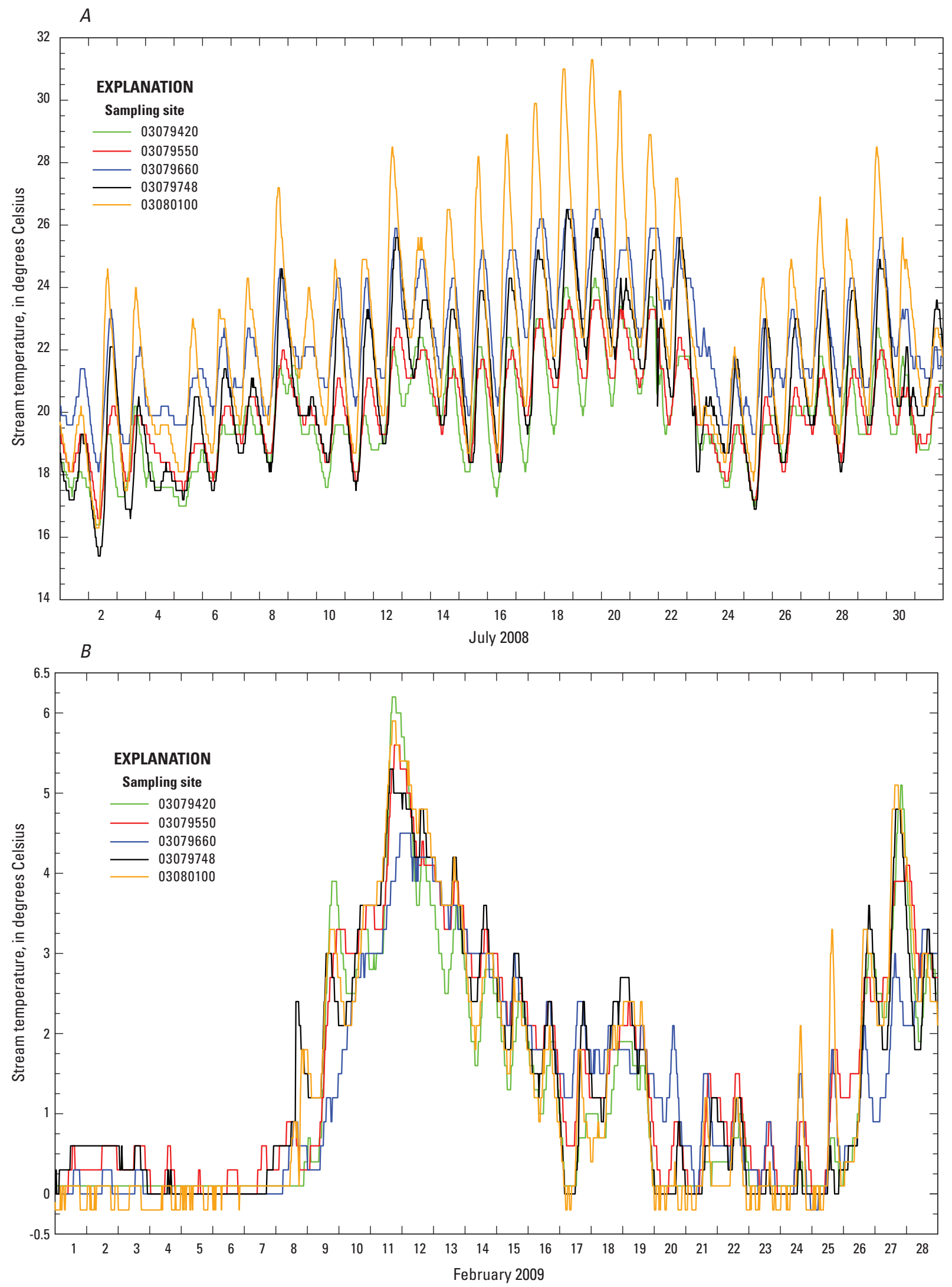

Figure 18. Stream temperatures for $A$, July 2008 and $B$, February 2009 for five sites along the main stem of Laurel Hill Creek, southwestern, Pennsylvania. 
five stations ranged from $27.2{ }^{\circ} \mathrm{C}$ (August 3,2007 ) at station 03079660 to $32.8^{\circ} \mathrm{C}$ (July 31,2007 ) at station 03080100 , both during low-flow conditions. The streamflow for Laurel Hill Creek at Ursina (station 03080000) for August 3, 2007, and July 31,2007 , were 4.0 and 11 cubic feet per second $\left(\mathrm{ft}^{3} / \mathrm{s}\right)$, respectively (appendix 3). The flow distribution at station 03080000 for the entire period when the stream temperature probes were deployed (July 17, 2007-July 8, 2010) indicates that streamflows of 4 and $11 \mathrm{ft}^{3} / \mathrm{s}$ were in the bottom 1 percent; that is, daily streamflow at station 03080000 was higher than $11 \mathrm{ft}^{3} / \mathrm{s}$ for about 99 percent of the days over the approximately 3-year period.

During winter months, there was a range of only $0.4{ }^{\circ} \mathrm{C}$ in average minimum and a range of $0.6{ }^{\circ} \mathrm{C}$ in average maximum stream temperatures among sites (table 1). The average minimum stream temperatures ranged from $1.0{ }^{\circ} \mathrm{C}$ (station 03079420) to $1.4^{\circ} \mathrm{C}$ (station 03079660), whereas the average maximum temperatures ranged from $1.9^{\circ} \mathrm{C}$ (station 03079420) to $2.5^{\circ} \mathrm{C}$ (station 03080100). Similar to the summer months, the lowest stream temperatures were measured in the upper part of the basin at Duck Pond Road (station 03079420).

\section{Chemistry of Groundwater}

Results of analyses of groundwater (wells and springs) samples collected in summer-fall 2007 indicate that water quality was somewhat affected by land use, although the main control on the quality of water was the bedrock formation contributing water to the well or spring. Water-quality samples were collected from six different geologic formations. The Loyalhanna Limestone Formation is the only formation in the basin that was not sampled, and only one well (two samples) within the Casselman Formation was sampled (appendix 4). Well depths ranged from 42 to $410 \mathrm{ft}$ for 18 of 19 wells for which depth data were available; average well depth is about $150 \mathrm{ft}$ (appendix 4).

For the seven geologic formations that are present in the basin, the Mauch Chunk Formation has historically been identified as the best unit for water yields and quality of water. This is reflected in the location of public-supply wells in the basin, all of which are drilled into the Mauch Chunk Formation, which underlies mountainous areas along the western boundary of the basin (fig. 7). MCLs have been established for As $(4 \mu \mathrm{g} / \mathrm{L})$ and $\mathrm{NO}_{3}(10 \mathrm{mg} / \mathrm{L}$ as $\mathrm{N})$; neither was exceeded in any groundwater sample collected in the Laurel Hill Creek Basin. The highest concentration for As was $1.30 \mu \mathrm{g} / \mathrm{L}$ (fig. 19), and the highest concentration for nitrate-N was $2.38 \mathrm{mg} / \mathrm{L}$ (appendix 4). The highest As concentration was detected in groundwater from a well drilled into the Glenshaw Formation. This same well (SO-874) was the deepest well $(410 \mathrm{ft})$ sampled in the basin, and it had the second highest measured SC $\left(425 \mu \mathrm{S} / \mathrm{cm}\right.$ at $\left.25^{\circ} \mathrm{C}\right)$ of all the wells and springs sampled. The high SC and depth of the well indicate that the high As concentration could be related to the flow path and residence time of the groundwater (Freeze and
Cherry, 1979, p.241). Groundwater with longer flow paths and residence times typically is more enriched in dissolved constituents. Eight other groundwater samples were collected from the Glenshaw Formation for As analysis, but only one sample exceeded $0.3 \mu \mathrm{g} / \mathrm{L}$ for As. The other seven concentrations were no greater than $0.12 \mu \mathrm{g} / \mathrm{L}$ (appendix 4). The groundwater sample with the highest nitrate concentration was collected from a spring that is in an agricultural area underlain by the Glenshaw Formation. The three highest (one spring, two wells) nitrate concentrations measured in groundwater $(0.79,1.98$, and $2.38 \mathrm{mg} / \mathrm{L})$ were all in samples from sites in agricultural settings underlain by the Glenshaw Formation. Another well sampled in an agricultural setting underlain by the Glenshaw Formation had nitrate- $\mathrm{N}$ below the detection level of $0.06 \mathrm{mg} / \mathrm{L}$, indicating that agricultural land use does not necessarily equate to elevated nitrate- $\mathrm{N}$ concentrations.

Some groundwater samples exceeded the SMCL values for Fe and Mn. Thirty-four samples were collected for Fe analyses, and 15 of these exceeded the SMCL value of $300 \mu \mathrm{g} / \mathrm{L}$. Only 1 of 7 samples collected from springs exceeded the SMCL for Fe, whereas 52 percent of the well samples (14 of 27) exceeded the SMCL for Fe. Fe concentrations for springs ranged from nondetect to $303 \mu \mathrm{g} / \mathrm{L}$ (appendix 4; median $=12 \mu \mathrm{g} / \mathrm{L}$ ), whereas Fe concentrations for wells ranged from nondetect to $10,400 \mu \mathrm{g} / \mathrm{L}$ (median $=345 \mu \mathrm{g} / \mathrm{L}$ ). Thirty-six samples were collected for Mn analyses, and 19 of these exceeded the SMCL value of $50 \mu \mathrm{g} / \mathrm{L}$. Five of 9 samples collected from springs exceeded the SMCL for Mn, whereas 52 percent of the well samples (14 of 27) exceeded the SMCL for Mn (fig. 19 and appendix 4). Mn values for spring samples ranged from 1 to $157 \mu \mathrm{g} / \mathrm{L}$ (median $=52 \mu \mathrm{g} / \mathrm{L}$ ), whereas Mn values in samples from wells ranged from 0.9 to $605 \mu \mathrm{g} / \mathrm{L}$ (median $=69 \mu \mathrm{g} / \mathrm{L}$ ). The median DO concentrations for springs and wells sampled were 7.9 and $1.7 \mathrm{mg} / \mathrm{L}$, respectively. It was expected that concentrations of dissolved $\mathrm{Mn}$ in samples from springs would be lower than in samples from wells because, at the spring discharge, some Mn would have precipitated out of solution as a result of oxidation. Also, the median SC values for springs and wells were 48 and $198 \mu \mathrm{S} / \mathrm{cm}$ at $25^{\circ} \mathrm{C}$, respectively; therefore, water from springs was generally lower in dissolved solids than well water and this could also be a contributing factor in lower Mn concentrations from springs.

Concentrations of $\mathrm{Fe}$ and $\mathrm{Mn}$ were somewhat related to geologic unit. Seventy-eight percent of the groundwater samples (wells and springs) collected in areas underlain by the Allegheny Formation exceeded the SMCL for Fe, and 78 percent also exceeded the SMCL for Mn. The highest Fe concentration $(10,400 \mu \mathrm{g} / \mathrm{L})$ was detected in a sample collected from a well within the Allegheny Formation. For groundwater samples collected from the Pottsville Formation, 43 percent exceeded the SMCL for Fe, and 62 percent exceeded the SMCL for Mn. The highest Mn concentration $(605 \mu \mathrm{g} / \mathrm{L})$ was detected in a sample collected from the Pottsville Formation. Only 33 percent of the samples collected from wells within the Mauch Chunk Formation exceeded the SMCL 
for Fe, and the same was true for Mn. Forty percent of the samples collected from the Glenshaw Formation exceeded the SMCL for Mn, whereas only 11 percent of the samples collected from this formation exceeded the SMCL for Fe (appendix 4; fig. 19). The concentrations of Fe and Mn in groundwater samples were somewhat consistent with the concentrations in samples from tributaries draining these formations. The highest $\mathrm{Fe}$ and $\mathrm{Mn}$ concentrations for tributaries were detected in samples from tributaries draining the Pottsville Formation (72 and $181 \mu \mathrm{g} / \mathrm{L}$, respectively). The highest median Fe concentration for tributaries $(22 \mu \mathrm{g} / \mathrm{L})$ was in a surface-water sample from the Allegheny Formation (fig. 17).

Samples analyzed for Al did not exceed or were within the SMCL (range of 50 to $200 \mu \mathrm{g} / \mathrm{L}$ ). Al was primarily analyzed in spring-water samples. Two of six samples had concentrations $(85.8$ and $62 \mu \mathrm{g} / \mathrm{L}$ ) within the $\mathrm{Al}$ SMCL range (appendix 4). Both of the spring samples that were within the SMCL range for Al were collected in areas underlain by the Pottsville Formation. All other groundwater samples had Al concentrations below $50 \mu \mathrm{g} / \mathrm{L}$.

None of the groundwater samples exceeded the SMCL or PWS acceptable concentrations for $\mathrm{Cl}$ and $\mathrm{SO}_{4}$ (fig. 19). The highest measured $\mathrm{Cl}$ concentration was $73.2 \mathrm{mg} / \mathrm{L}$ in well SO-870 completed in the Mauch Chunk Formation. The highest measured SO4 concentration was $166 \mathrm{mg} / \mathrm{L}$ in well SO-869 completed in the Pottsville Formation (appendix 4).

Many groundwater samples did not fall within the acceptable range for $\mathrm{pH}$ based on the EPA SMCL. Forty-three percent of the groundwater samples collected were either less than $\mathrm{pH} 6.5$ or greater than $\mathrm{pH}$ 8.5. Only one groundwater sample exceeded a $\mathrm{pH}$ of 8.5 ; in contrast, 18 samples had $\mathrm{pH}$ values below 6.5 (appendix 4). The $\mathrm{pH}$ and buffer capacity of groundwater samples are related to geologic formation. The highest median $\mathrm{pH}$ values were measured in groundwater samples collected in areas underlain by the Mauch Chunk (median $\mathrm{pH}, 7.6$ ) and the Casselman (median $\mathrm{pH}, 7.4$ ) Formations (table 2). The lowest median $\mathrm{pH}$ values were measured in groundwater samples collected from the Pottsville (median $\mathrm{pH}, 5.3$ ) and the Allegheny (median $\mathrm{pH}, 6.2$ ) Formations. Seventy and sixty percent, respectively, of groundwater samples collected from the Pottsville and Allegheny Formations had $\mathrm{pH}$ values less than 6.5. Water with $\mathrm{pH}$ values less than 6.5 can cause corrosion problems in water-supply systems (U.S. Environmental Protection Agency, 2015b).

Similarly, the highest median alkalinity value (for a formation with more than two samples collected) was measured in groundwater from the Mauch Chunk Formation $\left[80 \mathrm{mg} / \mathrm{L}\right.$ calcium carbonate $\left.\left(\mathrm{CaCO}_{3}\right)\right]$, and the lowest median alkalinity values were measured in samples collected from the Pottsville $\left(4 \mathrm{mg} / \mathrm{L} \mathrm{CaCO}_{3}\right)$ and Allegheny $\left(38 \mathrm{mg} / \mathrm{L} \mathrm{CaCO}_{3}\right)$ Formations (fig. 19). Surface-water samples collected from areas underlain by the Pottsville and Allegheny Formations also showed low $\mathrm{pH}$ values relative to other formations.

SC data also showed a relation to geologic unit (fig. 19); however, land use also had some influence. Samples collected in areas underlain by the Pottsville and Allegheny
Formations had the lowest median SC values (48 and $106 \mu \mathrm{S} / \mathrm{cm}$ at $25^{\circ} \mathrm{C}$, respectively). All the groundwater samples collected from the Pottsville Formation were from forested areas. The range of SC values for Pottsville Formation samples ( 10 samples) was $29-130 \mu \mathrm{S} / \mathrm{cm}$ at $25^{\circ} \mathrm{C}$. For samples collected from the Allegheny Formation, the highest $\mathrm{SC}$ value $\left(689 \mu \mathrm{S} / \mathrm{cm}\right.$ at $\left.25^{\circ} \mathrm{C}\right)$ was in groundwater from a well (SO-869) located in an agricultural area; however, this well had a nitrate-N concentration of less than $0.06 \mathrm{mg} / \mathrm{L}$. Dissolved $\mathrm{Ca}, \mathrm{Mg}$, and $\mathrm{SO}_{4}$ concentrations for well SO-869 were the highest measured for any groundwater samples. The three highest $\mathrm{SC}$ values for all groundwater samples collected were from wells in agricultural areas (appendix 4). The second and third highest $\mathrm{SC}$ values were measured in samples from two wells (SO-871 and SO-874) in the Glenshaw Formation. These two wells also had the second and third highest nitrate$\mathrm{N}$ concentrations; however, the relatively high $\mathrm{SC}$ was primarily due to elevated concentrations of $\mathrm{Ca}, \mathrm{Mg}$, and carbonate.

There were differences in water quality between samples collected from springs and samples collected from wells overlying the same formation. The primary difference is related to the quantity of dissolved ions in the water. As stated by McElroy (2000), total mineralization is lower in springs than in wells because spring water generally circulates in the shallow subsurface, giving a shorter residence time. Higher $\mathrm{SC}$ values were observed in well water than in spring water for each geologic formation (table 2). The median $\mathrm{SC}$ value for all springs sampled was $48 \mu \mathrm{S} / \mathrm{cm}$ at $25^{\circ} \mathrm{C}$, whereas the median for all wells sampled was $198 \mu \mathrm{S} / \mathrm{cm}$ at $25^{\circ} \mathrm{C}$. The difference in dissolved ions between samples from wells and samples from springs was evident for most constituents. For example, the median $\mathrm{Fe}$ and $\mathrm{Mn}$ concentrations in water from wells in areas underlain by the Allegheny Formation were 1,970 and $281 \mu \mathrm{g} / \mathrm{L}$, respectively, and the median Fe and Mn concentrations in water from springs in the same setting were 55 and $91 \mu \mathrm{g} / \mathrm{L}$, respectively (table 2 ).

\section{Chemical Relation Between Surface Water and Groundwater}

Generally, near-neutral stream samples are present in the main stem of Laurel Hill Creek where groundwater contributions may be increasingly important. Tributary sites had a lower mean $\mathrm{pH}$ and alkalinity than the main-stem sites. The mean $\mathrm{pH}$ and alkalinity for samples collected in 2007 were 6.5 and $21 \mathrm{mg} / \mathrm{L} \mathrm{CaCO}_{3}$, respectively, at tributary sites, and 7.3 and $28 \mathrm{mg} / \mathrm{L} \mathrm{CaCO}_{3}$, respectively, at main-stem sites. The average alkalinity in all well samples collected in 2007 was $78 \mathrm{mg} / \mathrm{L} \mathrm{CaCO}_{3}$. The groundwater acquires alkalinity by reaction with carbonate minerals. Inflows of groundwater to the main stem added alkalinity to the main stem.

The mean SC for samples collected in 2007 in the main stem $\left(256 \mu \mathrm{S} / \mathrm{cm}\right.$ at $\left.25^{\circ} \mathrm{C}\right)$ was higher than the mean for the tributaries $\left(165 \mu \mathrm{S} / \mathrm{cm}\right.$ at $\left.25^{\circ} \mathrm{C}\right)$, and wells $(180 \mu \mathrm{S} / \mathrm{cm}$ at $25^{\circ} \mathrm{C}$ ). This is reflective of the high dissolved ion input 


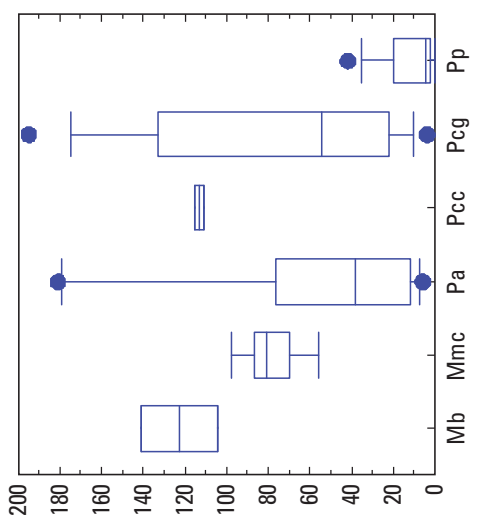

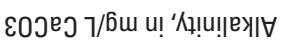
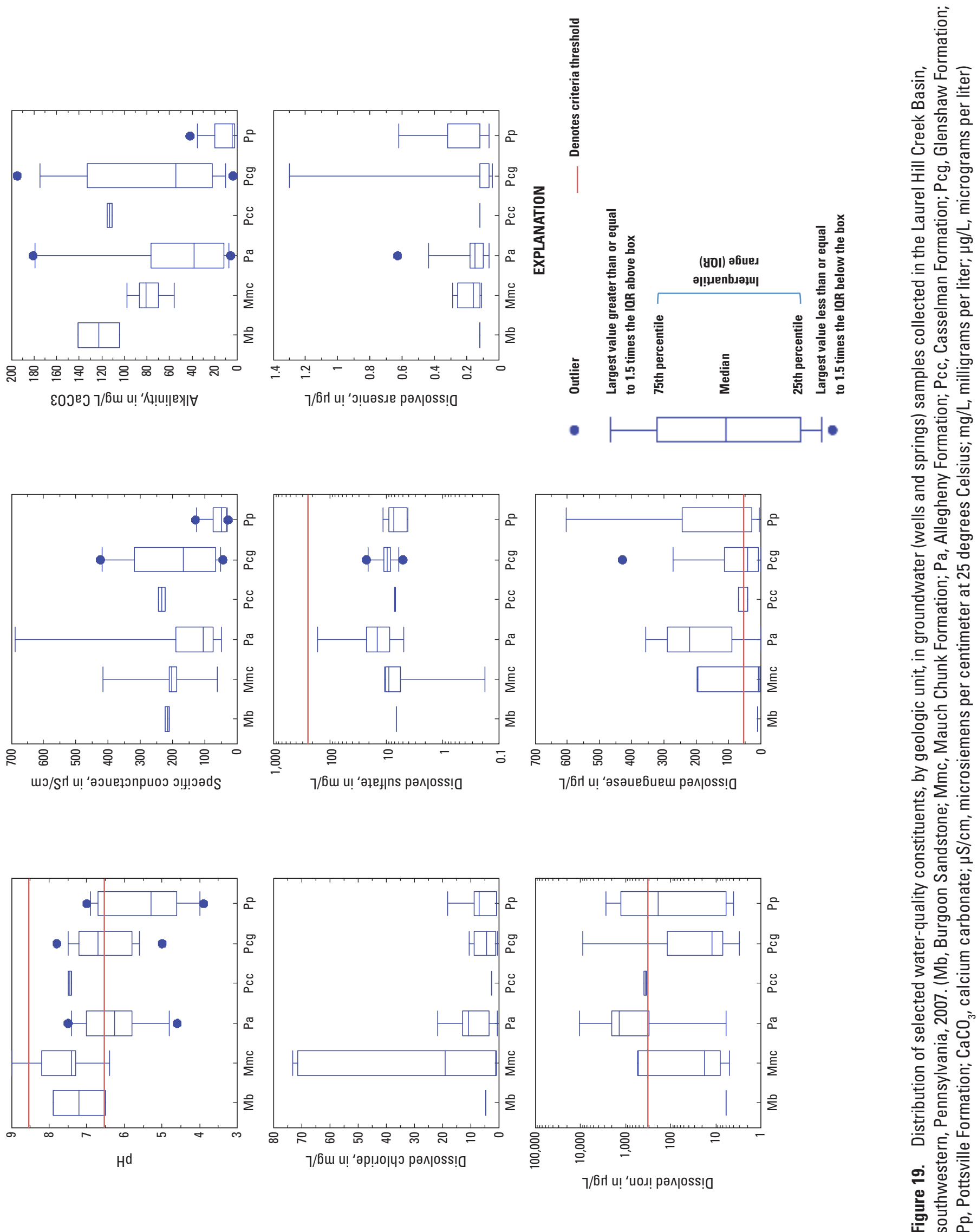
Table 2. Median values for specific conductance, $\mathrm{pH}$, iron, and manganese, by geologic formation, for spring and well water samples collected in the Laurel Hill Creek Basin, southwestern, Pennsylvania, 2007.

[NA, not applicable; n, number of observations]

\begin{tabular}{|c|c|c|c|c|c|c|c|c|c|c|c|c|c|}
\hline \multirow{3}{*}{ Constituent } & \multirow{3}{*}{ Type } & \multicolumn{12}{|c|}{ Formation } \\
\hline & & \multicolumn{2}{|c|}{$\begin{array}{l}\text { Burgoon } \\
\text { Sandstone }\end{array}$} & \multicolumn{2}{|c|}{ Mauch Chunk } & \multicolumn{2}{|c|}{ Allegheny } & \multicolumn{2}{|c|}{ Casselman } & \multicolumn{2}{|c|}{ Glenshaw } & \multicolumn{2}{|c|}{ Pottsville } \\
\hline & & $\mathbf{n}$ & Median & $\mathbf{n}$ & Median & $\mathbf{n}$ & Median & $\mathrm{n}$ & Median & $\mathbf{n}$ & Median & $\mathrm{n}$ & Median \\
\hline \multirow{3}{*}{$\begin{array}{l}\text { Specific conductance, } \\
\text { in microsiemens } \\
\text { per centimeter at } 25 \\
\text { degrees Celsius }\end{array}$} & Spring & NA & NA & 1 & 62 & 3 & 71 & NA & NA & 1 & 45 & 6 & 33 \\
\hline & Well & 2 & 217 & 8 & 205 & 6 & 108 & 2 & 234 & 10 & 212 & 4 & 86 \\
\hline & Spring & NA & NA & 1 & 6.4 & 3 & 6.8 & NA & NA & 1 & 5.0 & 6 & 5.0 \\
\hline $\mathrm{pH}$, in stardard units & Well & 2 & 7.2 & 8 & 7.6 & 7 & 6.2 & 2 & 7.4 & 10 & 6.8 & 4 & 5.6 \\
\hline \multirow{2}{*}{$\begin{array}{l}\text { Iron, in micrograms } \\
\text { per liter }\end{array}$} & Spring & NA & NA & NA & NA & 3 & 55 & NA & NA & 1 & 12 & 3 & 6 \\
\hline & Well & 1 & 6 & 6 & 18 & 6 & 1,970 & 2 & 362 & 8 & 35 & 4 & 968 \\
\hline \multirow{2}{*}{$\begin{array}{l}\text { Manganese, in micro- } \\
\text { grams per liter }\end{array}$} & Spring & NA & NA & NA & NA & 3 & 91 & NA & NA & 1 & 19 & 5 & 52 \\
\hline & Well & 1 & 10 & 6 & 6.8 & 6 & 281 & 2 & 55 & 9 & 48 & 3 & 432 \\
\hline
\end{tabular}

from Clear Run in the upper part of the Laurel Hill Creek Basin. The $\mathrm{Cl}$ concentrations in the main stem of Laurel Hill Creek were elevated as a result of road salt applications.

The main stem in the upper part of the basin and tributary sites receiving wastewater had elevated concentrations of nutrients for samples collected in 2007. The groundwater samples did not indicate any nutrient issues. Both surface water and groundwater had elevated concentrations of Mn greater than the SMCL. The groundwater samples also showed Fe concentrations greater than the SMCL, whereas the surface-water samples were less than the SMCL, primarily owing to precipitation of dissolved $\mathrm{Fe}$ in the oxygenated stream environment.

\section{Water Quantity}

There are four exceptional value tributaries in the Laurel Hill Creek Basin that are designated high-quality cold-water fisheries. Water quantity is an important issue owing to the significant amount of daily water withdrawals from the basin and because of the importance of the groundwater contribution to streamflow temperature and water quality. Generally, the streamflow at a point is proportional to the upstream drainage area. Drainage area for the tributaries sampled in the Laurel Hill Creek Basin ranged from $0.35 \mathrm{mi}^{2}$ for May Run to $12.55 \mathrm{mi}^{2}$ for Fall Creek (table 3), with an average drainage area of about $3 \mathrm{mi}^{2}$. The drainage area for main-stem sites ranged from $4.36 \mathrm{mi}^{2}$ at site LHC-1st (station 03079320) to $121 \mathrm{mi}^{2}$ at LHC-U (station 03080000, Ursina, Pa.) (fig. 8; appendix 1).

\section{Characterization of Low Streamflow}

Streamflow was measured twice at sites along the main stem of Laurel Hill Creek and most of the tributaries during low-flow periods in June and September 2007 (fig. 8). The measured streamflows were very similar in June and September. The streamflows at tributary sites in June ranged from $0.01 \mathrm{ft}^{3} / \mathrm{s}$ ) for May Run (station 03079926) to $2.4 \mathrm{ft}^{3} / \mathrm{s}$ for Jones Mill Run (station 03079640) and Kooser Run (station 03079480, whereas in September, the range was $0.06 \mathrm{ft}^{3} / \mathrm{s}$ for Cole Run (station 03079704) to $2.6 \mathrm{ft}^{3} / \mathrm{s}$ for Jones Mill Run (table 3). For the main stem sites, the range in streamflow in June was $0.1 \mathrm{ft}^{3} / \mathrm{s}$ for LHC-1st (at Lavansville, station 03079320) to $20 \mathrm{ft}^{3} / \mathrm{s}$ at LHC-A9 (near Humbert, station 03079993), whereas for September, the range was $0.47 \mathrm{ft}^{3} / \mathrm{s}$ at LHC-1st to $20 \mathrm{ft}^{3} / \mathrm{s}$ at LHC-U (at Ursina, station 03080000) (table 3). The mean daily discharges computed for station 03080000 , based on the continuous stage record for June 25-27, 2007, and September 17-19, 2007, were 16 and $17 \mathrm{ft}^{3} / \mathrm{s}$, respectively. On the basis of the historical streamflow record for station 03080000 from 1919-2007, a streamflow of $16 \mathrm{cfs}$ is between the 5th and 10th percentile of streamflow for June 25-27, and a streamflow of $17 \mathrm{ft}^{3} / \mathrm{s}$ is between the 25 th and 50th percentile of streamflow for September 17-19.

For tributary sites, the flow per unit area (the area of the drainage basin) was related to the location of the drainage network within the Laurel Hill Creek Basin. Tributaries with a drainage network that extends into the western sections of the basin and thus receives some recharge water from the western ridge had higher flows per unit area than tributaries with 
Table 3. Measured streamflow and drainage area for surface-water sites sampled in the Laurel Hill Creek Basin, southwestern Pennsylvania, 2007.

[yyyymmdd, year, month, day; $\mathrm{ft}^{3} / \mathrm{s}$, cubic feet per second; DA, drainage area; $\mathrm{mi}^{2}$, square miles; SF/A, streamflow per area; $\mathrm{ft}^{3} / \mathrm{s} / \mathrm{mi}^{2}$, cubic feet per second per square mile; in/yr, inches per year]

\begin{tabular}{|c|c|c|c|c|c|c|c|c|c|}
\hline $\begin{array}{l}\text { Station } \\
\text { number }\end{array}$ & $\begin{array}{l}\text { Local } \\
\text { identifier }\end{array}$ & $\begin{array}{l}\text { Latitude } \\
\text { (decimal } \\
\text { degrees) }\end{array}$ & $\begin{array}{l}\text { Longitude } \\
\text { (decimal } \\
\text { degrees) }\end{array}$ & $\begin{array}{l}\text { Date, } \\
\text { yyyym- } \\
\text { mdd }\end{array}$ & Time & $\begin{array}{c}\text { Stream- } \\
\text { flow, } \\
\mathrm{ft}^{3} / \mathrm{s}\end{array}$ & $\begin{array}{l}\text { DA, } \\
\mathrm{mi}^{2}\end{array}$ & $\begin{array}{c}\mathrm{SF} / \mathrm{A}, \\
\mathrm{ft}^{3} / \mathrm{s} / \mathrm{mi}^{2}\end{array}$ & SF/A, in/yr \\
\hline 03079350 & Crab Run & 40.0611 & -79.1658 & 20070627 & 1330 & 0.2 & 4.12 & 0.05 & 0.66 \\
\hline 03079400 & Clear Run & 40.0742 & -79.1772 & 20070625 & 1115 & 1.5 & 4.98 & 0.30 & 4.09 \\
\hline 03079418 & Shanks Run & 40.0589 & -79.1914 & 20070627 & 1315 & 0.09 & 0.8 & 0.11 & 1.53 \\
\hline 030794464 & Moore Run & 40.0681 & -79.2092 & 20070627 & 1245 & 0.06 & 0.67 & 0.09 & 1.22 \\
\hline 030794464 & Moore Run & 40.0681 & -79.2092 & 20070919 & 1300 & 0.13 & 0.67 & 0.19 & 2.63 \\
\hline 030794467 & Shafer Run & 40.0531 & -79.2014 & 20070627 & 1230 & 1.2 & 4.89 & 0.25 & 3.33 \\
\hline 03079480 & Kooser Run & 40.0442 & -79.2175 & 20070917 & 1200 & 2.3 & 3.76 & 0.61 & 8.30 \\
\hline 03079520 & Gross Run & 40.0319 & -79.2250 & 20070627 & 1130 & 0.25 & 1.17 & 0.21 & 2.90 \\
\hline 03079520 & Gross Run & 40.0319 & -79.2250 & 20070919 & 1210 & 0.46 & 1.17 & 0.39 & 5.34 \\
\hline 03079540 & Crise Run & 40.0281 & -79.2286 & 20070627 & 1145 & 0.2 & 0.92 & 0.22 & 2.95 \\
\hline 03079540 & Crise Run & 40.0281 & -79.2286 & 20070919 & 1130 & 0.16 & 0.92 & 0.17 & 2.36 \\
\hline 03079580 & Buck Run & 40.0189 & -79.2411 & 20070627 & 1100 & 0.18 & 0.87 & 0.21 & 2.81 \\
\hline 03079580 & Buck Run & 40.0189 & -79.2411 & 20070919 & 1110 & 0.15 & 0.87 & 0.17 & 2.34 \\
\hline 03079640 & Jones Mill Run & 40.0025 & -79.2356 & 20070627 & 1030 & 2.4 & 4.92 & 0.49 & 6.62 \\
\hline 03079704 & Cole Run & 39.9728 & -79.2839 & 20070919 & 1010 & 0.06 & 1.06 & 0.06 & 0.77 \\
\hline 03079708 & Blue Hole Creek & 39.9589 & -79.2853 & 20070627 & 930 & 0.75 & 5.83 & 0.13 & 1.75 \\
\hline 03079708 & Blue Hole Creek & 39.9589 & -79.2853 & 20070918 & 1530 & 0.88 & 5.83 & 0.15 & 2.05 \\
\hline 03079710 & Fall Creek & 39.9579 & -79.2798 & 20070625 & 1530 & 1.7 & 12.55 & 0.14 & 1.84 \\
\hline 03079710 & Fall Creek & 39.9579 & -79.2798 & 20070917 & 1615 & 1.6 & 12.55 & 0.13 & 1.73 \\
\hline 03079740 & Lost Creek & 39.9475 & -79.2658 & 20070625 & 1645 & 0.24 & 4.16 & 0.06 & 0.78 \\
\hline 03079740 & Lost Creek & 39.9475 & -79.2658 & 20070918 & 1445 & 0.24 & 4.16 & 0.06 & 0.78 \\
\hline 03079770 & Whipkey Run & 39.9136 & -79.3061 & 20070626 & 1330 & 0.07 & 2.54 & 0.03 & 0.37 \\
\hline 03079770 & Whipkey Run & 39.9136 & -79.3061 & 20070918 & 1200 & 0.07 & 2.54 & 0.03 & 0.37 \\
\hline 03079786 & Mose King Run & 39.9008 & -79.3108 & 20070626 & 1130 & 0.02 & 2.21 & 0.01 & 0.12 \\
\hline 03079830 & Sandy Run & 39.9331 & -79.3367 & 20070626 & 1415 & 0.73 & 5 & 0.15 & 1.98 \\
\hline 03079830 & Sandy Run & 39.9331 & -79.3367 & 20070918 & 1130 & 1 & 5 & 0.20 & 2.71 \\
\hline 03079850 & Harbaugh Run & 39.9244 & -79.3569 & 20070627 & 830 & 0.19 & 1.91 & 0.10 & 1.35 \\
\hline
\end{tabular}


Table 3. Measured streamflow and drainage area for surface-water sites sampled in the Laurel Hill Creek Basin, southwestern Pennsylvania, 2007.-Continued

[yyyymmdd, year, month, day; $\mathrm{ft}^{3} / \mathrm{s}$, cubic feet per second; DA, drainage area; $\mathrm{mi}^{2}$, square miles; SF/A, streamflow per area; $\mathrm{ft}^{3} / \mathrm{s} / \mathrm{mi}^{2}, \mathrm{cubic}$ feet per second per square mile; in/yr, inches per year]

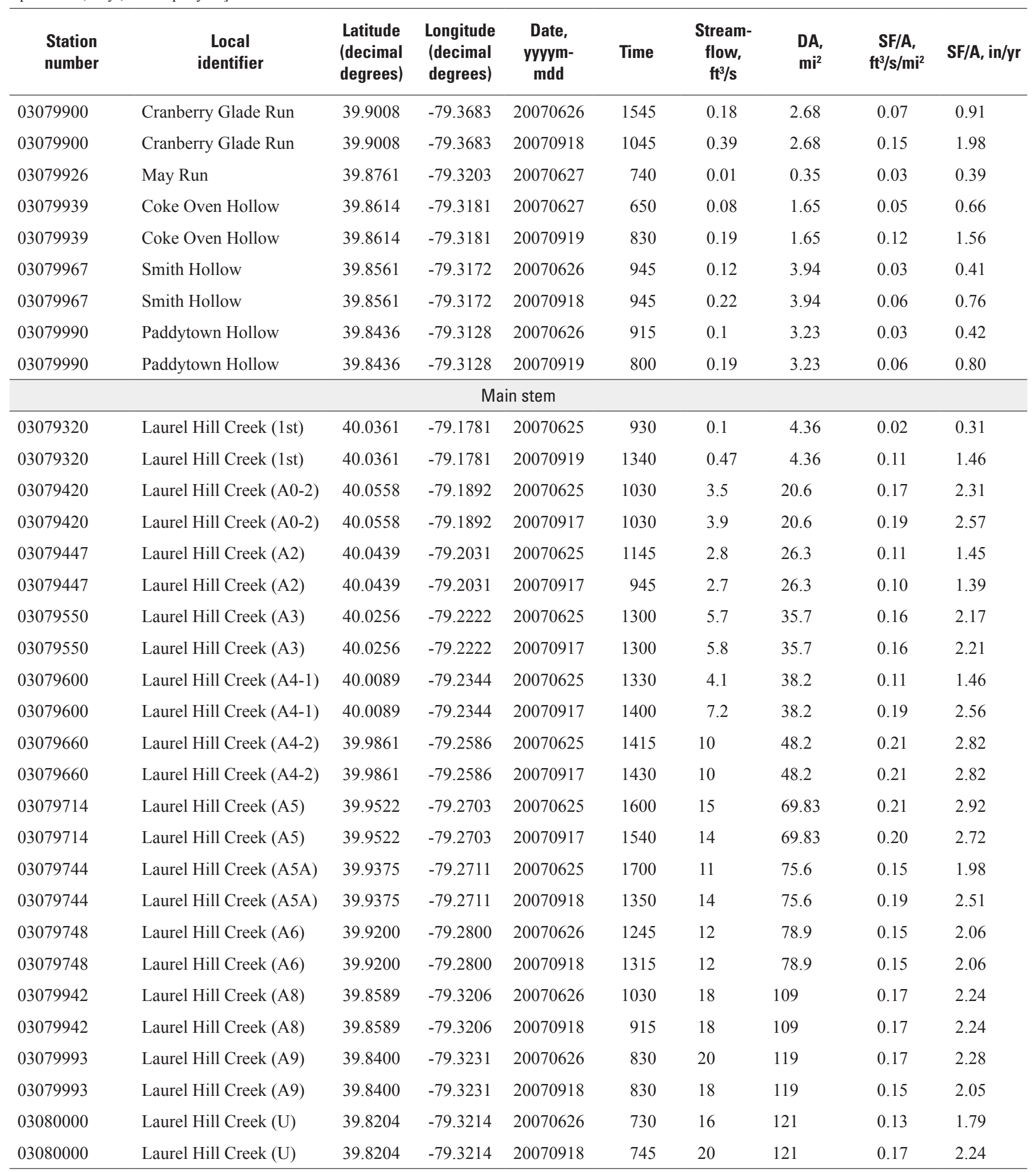


a drainage network that is primarily in the eastern or central parts of the basin. The mean flow per unit area for tributaries draining eastern or central sections was 0.05 cubic feet per second per square mile $\left(\mathrm{ft}^{3} / \mathrm{s} / \mathrm{mi}^{2}\right)$ or about 0.7 inches per year (in/yr). Tributaries draining areas that extend into the western ridge had a mean flow per unit area of $0.24 \mathrm{ft}^{3} / \mathrm{s} / \mathrm{mi}^{2}$ or about $3 \mathrm{in} / \mathrm{yr}$ (table 3 ). Areas along the western ridge of the basin have the highest annual precipitation rates due to orographic influences (fig. 4); in addition, ridge tops typically have higher recharge rates than adjacent areas as a result of the proximity of the bedrock to land surface, which promotes recharge to groundwater aquifers due to the typically shallow nature of soils along the ridges. Farther down in the basin, the soils are deeper; the water can be captured within the soil zone and then can be evaporated or transpired to a greater extent relative to ridge top locations. The tributaries with the highest mean flow per unit area were Kooser Run $\left(0.62 \mathrm{ft} 3 / \mathrm{s} / \mathrm{mi}^{2}\right)$, Jones Mill Run $\left(0.51 \mathrm{ft}^{3} / \mathrm{s} / \mathrm{mi}^{2}\right)$, and Allen Creek (station $03079670 ; 0.38 \mathrm{ft}^{3} / \mathrm{s} / \mathrm{mi}^{2}$ ). The drainage areas for these three streams are all greater than $3.7 \mathrm{mi}^{2}$. The tributaries with the lowest flow per unit area were Mose King Run (station 03079786) (0.01 ft $\left.3 / \mathrm{s} / \mathrm{mi}^{2}\right)$, Whipkey Run (station 03079770 ; $\left.0.03 \mathrm{ft}^{3} / \mathrm{s} / \mathrm{mi}^{2}\right)$, and May Run $\left(0.03 \mathrm{ft}^{3} / \mathrm{s} / \mathrm{mi}^{2}\right)$. These three streams all drain areas in the central to eastern part of the basin, and they all have drainage areas less than $2.6 \mathrm{mi}^{2}$.

As indicated above, the amount of flow per unit area at the tributary sites was affected by the size of the drainage area. Tributary subbasins with a drainage area less than $3 \mathrm{mi}^{2}$ had a mean flow per unit area of $0.12 \mathrm{ft}^{3} / \mathrm{s} / \mathrm{mi}^{2}$, whereas tributary sites with a drainage area greater than $3 \mathrm{mi}^{2}$ had a mean flow per unit area of $0.23 \mathrm{ft}^{3} / \mathrm{s} / \mathrm{mi}^{2}$. One reason (in addition to effects of spatial location and subsequent topographic influences) for the difference between small and (relatively) large tributary subbasins is that groundwater beneath the smaller subbasins can flow more readily to an adjacent subbasin than groundwater beneath large subbasins.

The tributary sites with large drainage areas had higher flow per unit area than main-stem sites along Laurel Hill Creek. The average flow per unit area for the main stem sites was $0.16 \mathrm{ft}^{3} / \mathrm{s} / \mathrm{mi}^{2}$. The main stem of the creek integrates the recharge water from both sides of the basin, so it is reasonable to think that the main stem could have lower flow per unit area than tributary sites draining the western ridge. There are major water withdrawals in the basin from the surface-water and groundwater systems. On the basis of 2009 water-use data, $1.04 \mathrm{Mgal} / \mathrm{d}\left(1.61 \mathrm{ft}^{3} / \mathrm{s}\right)$ was removed directly from the surface-water system (table 4), all from the main stem in the upper part of the basin. The groundwater withdrawals occurred across the basin but were primarily concentrated along the western ridge in the northern one-half of the basin. The effects of water withdrawals on streamflow would be most apparent for the main stem because drainage area for the main stem integrates all water withdrawals. The daily net withdrawal rate from surface water and groundwater of $1.93 \mathrm{Mgal} / \mathrm{d}$ is equal to $3.0 \mathrm{ft}^{3} / \mathrm{s}$. If this net withdrawal is added to the measured flows for all the sites along the main stem downstream from the drinking water reservoir in Bakersville [the reservoir is immediately upstream from surface-water site LHC-A2 (station 03079447); fig. 8], the mean flow per unit area for the main stem sites is $0.22 \mathrm{ft}^{3} / \mathrm{s} / \mathrm{mi}^{2}$, which is slightly less than the flow per unit area for larger tributary sites.

Streamflow measured along the main stem of Laurel Hill Creek showed a fairly stable flow to unit area relation in the middle to lower sections of the basin, whereas the upper section was affected by drainage-area size and water withdrawals. The upper most site sampled along the main stem (LHC-1st) had a mean flow per unit area of $0.07 \mathrm{ft}^{3} / \mathrm{s} / \mathrm{mi}^{2}$, which was the lowest ratio for all sites sampled on the main stem. Site LHC-A0-2 (station 03079420) upstream from the drinking-water reservoir in Bakersville had a mean value of $0.18 \mathrm{ft}^{3} / \mathrm{s} / \mathrm{mi}^{2}$, but the value was substantially less for LHC-A2 (mean, $0.10 \mathrm{ft}^{3} / \mathrm{s} / \mathrm{mi}^{2}$ ), which is downstream from the drinkingwater reservoir. Downstream from the drinking-water reservoir, nine measurements were made at main-stem sites during both synoptic events, and the mean values ranged from 0.15 to $0.21 \mathrm{ft}^{3} / \mathrm{s} / \mathrm{mi}^{2}$. The highest values were for two sites [LHCA4-2 (station 03079660) and LHC-A5 (station 03079714)] immediately downstream from Laurel Hill Lake (table 3). It appears that the lake was augmenting flow during low-flow periods.

\section{Water Use}

According to water-use data compiled for 2003 and 2009, the net water withdrawals from the basin (both groundwater and surface-water sources) equaled 2.01 and $1.93 \mathrm{Mgal} / \mathrm{d}$, respectively. Data for 2009 indicate that the total withdrawals equaled 2.22 Mgal/d, whereas the total discharges equaled 0.29 Mgal/d (table 4). For registered users, 1.04 and $0.95 \mathrm{Mgal} / \mathrm{d}$ were from surface-water and groundwater sources, respectively, with the remaining $0.23 \mathrm{Mgal} / \mathrm{d}$ attributed to non-registered users. Approximately 57 percent of the registered withdrawals were attributed to public-water suppliers. It is likely that most of the unregistered withdrawals were from either groundwater wells or springs. Approximately 39 and 43 percent of the unregistered withdrawals were attributed to commercial entities and agriculture, respectively; the remaining unregistered use was primarily residential.

There were only six registered discharge locations in the basin. Sixty-five percent of the discharge water came from the dewatering of a quarry; this water was discharged back into the surface-water system. Twenty percent of the total discharge water was wastewater, and the remaining 15 percent was back flow from the water-treatment plant of a publicwater supplier. One public-water supplier in the basin exports wastewater to an adjacent basin. The average daily export of wastewater using data from 2005 to 2010 was $1.10 \mathrm{Mgal} / \mathrm{d}$ $\left(1.71 \mathrm{ft}^{3} / \mathrm{s}\right)$.

During times of drought, total water use in the basin theoretically drops by $0.04 \mathrm{Mgal} / \mathrm{d}$, based on reduced withdrawals by one of the public-water suppliers in the basin. The drought contingency plan (in place during the late 2000s) developed 
Table 4. Summary of water discharges and withdrawals within Laurel Hill Creek Basin, southwestern, Pennsylvania, 2009.

[ $>=$, greater than or equal to; --, no data; Mgal/d, million gallons per day]

\begin{tabular}{|c|c|c|c|c|c|c|c|}
\hline \multirow{2}{*}{ Water use } & \multirow{2}{*}{$\begin{array}{c}\text { Number of } \\
\text { water use } \\
\text { points }\end{array}$} & \multirow{2}{*}{$\begin{array}{c}\text { Number of } \\
\text { values } \\
>=0.01 \\
\text { Mgal/d }\end{array}$} & \multicolumn{4}{|c|}{ Water use, in Mgal/d } & \multirow{2}{*}{$\begin{array}{c}\text { Percent of } \\
\text { total water } \\
\text { use }\end{array}$} \\
\hline & & & Mean & Minimum & Maximum & Total & \\
\hline \multicolumn{8}{|c|}{ Discharges } \\
\hline All discharges & 6 & 3 & 0.05 & 0.00 & 0.19 & 0.29 & -- \\
\hline All withdrawals & 377 & 12 & -- & -- & -- & 2.22 & -- \\
\hline \multicolumn{8}{|c|}{ Summary of withdrawals by source } \\
\hline Groundwater $^{1}$ & 17 & 8 & 0.06 & 0.00 & 0.21 & 0.95 & 43 \\
\hline \multicolumn{8}{|c|}{ Summary of withdrawals by water-use category } \\
\hline \multicolumn{8}{|l|}{ Registered } \\
\hline Water supplier & 6 & 6 & 0.21 & 0.01 & 0.86 & 1.27 & 57 \\
\hline Commercial & 10 & 3 & 0.05 & 0.00 & 0.18 & 0.49 & 22 \\
\hline Mineral & 3 & 1 & 0.08 & 0.00 & 0.21 & 0.23 & 10 \\
\hline Agriculture (Livestock) & 24 & 1 & 0.00 & 0.00 & 0.02 & 0.10 & 4 \\
\hline
\end{tabular}

${ }^{1}$ Described in registration data; does not include estimated water use.

${ }^{2}$ Estimated water use not identitifed as groundwater or surface water.

by the Somerset Borough Water Authority calls for substantial reductions in surface-water withdrawals but also substantial increases in groundwater withdrawals (Lawrence Kowatch, Somerset Borough Water Authority, written commun., 2010). The net effect is a $0.04 \mathrm{Mgal} / \mathrm{d}$ decrease. Surface water is withdrawn in the upper part of the Laurel Hill Creek Basin, and according to PaDEP, the primary water supplier must allow $1.37 \mathrm{Mgal} / \mathrm{d}$ to pass through the primary reservoir used for the intake of surface water. Once flow through the reservoir drops below $1.37 \mathrm{Mgal} / \mathrm{d}$, surface-water withdrawals are terminated and almost all of the water withdrawn in the basin is taken from groundwater sources.

\section{Water-Analysis Screening Tool (WAST)}

The WAST calculates a safe yield for different pour points within the basin (Stuckey, 2008). Water withdrawals in the Laurel Hill Creek Basin are primarily in the upper part of the basin. The total drainage area of the basin at the mouth equals $125 \mathrm{mi}^{2}$. Approximately 80 percent of the water withdrawals occur within the upper $36 \mathrm{mi}^{2}$ of the basin. One aspect of the WAST to note is that the value of a withdrawal from a groundwater well is equal to the value of a withdrawal from a surface-water site. This is based on the premise that one gallon of water removed from a well is one gallon of water that would not reach the receiving stream body. Given 
this algorithm within the WAST, the safe yield in the upper part of the basin at LHC-A3 (station 03079550; drainage area, $35.7 \mathrm{mi}^{2}$ ) (ISC or safe yield equals $0.315 \mathrm{Mgal} / \mathrm{d}$ ) is exceeded by the net withdrawals $(1.490 \mathrm{Mgal} / \mathrm{d})$ by $372 \mathrm{per}-$ cent. Just upstream, at LHC-A2 (station 03079447; drainage area, $\left.26.3 \mathrm{mi}^{2}\right)$, the ISC $(0.215 \mathrm{Mgal} / \mathrm{d})$ is exceeded by the net withdrawals (1.101 Mgal/d) by about 412 percent (table 5). In between these locations, there are two public-supply wells in the Shafer Run subbasin. The primary water-withdrawal sites in the basin are just upstream from LHC-A2, which is just downstream from a surface-water reservoir with the primary surface-water intake in the basin.

According to criteria established by PaDEP in the context of Act 220 (the Pennsylvania State Water Plan), a safe amount of water to withdraw on a daily basis from the entire Laurel Hill Creek Basin is $1.43 \mathrm{Mgal} / \mathrm{d}$. The safe amount of water to withdraw in Mgal/d is equal to the ISC (table 5). Using 2009 water-use data, the total withdrawal was $2.22 \mathrm{Mgal} / \mathrm{d}$, and the total discharge was $0.29 \mathrm{Mgal} / \mathrm{d}$. The total discharge value used by the WAST for the 2009 data was $0.33 \mathrm{Mgal} / \mathrm{d}$, which includes a conservation release value of $0.035 \mathrm{Mgal} / \mathrm{d}$ for a pond in the central part of the basin. The net withdrawals exceed the safe yield (ISC) for the basin by about $0.46 \mathrm{Mgal} / \mathrm{d}$ (about 32 percent) at the mouth of the basin (table 5). The ISC less net withdrawals is equal to the Screening Indicator (SI) in
$\mathrm{Mgal} / \mathrm{d}$. The exceedance of the safe yield by the net withdrawals in the basin was the primary reason that the Laurel Hill Creek Basin was nominated as a Critical Water Planning Area in 2010 by PaDEP.

Three subbasins had more than $0.1 \mathrm{Mgal} / \mathrm{d}$ of net withdrawals during 2009. These withdrawals were primarily from groundwater wells, but there were some withdrawals from spring sources. The subbasin most affected by water withdrawals is Allen Creek (drainage area, $4.6 \mathrm{mi}^{2}$ ), where withdrawals were approximately $0.36 \mathrm{Mgal} / \mathrm{d}$, which equates to about a 1,280 percent exceedance of a safe yield for the basin (table 5). The Kooser Run subbasin had net withdrawals of $0.31 \mathrm{Mgal} / \mathrm{d}$ for 2009 , which exceeded the safe yield for this $4.6 \mathrm{mi}^{2}$ subbasin by 1,060 percent. The primary water user in this subbasin is a limestone quarry in the upper part of the subbasin. Another subbasin that has significant water withdrawals is Shafer Run (drainage area, $4.89 \mathrm{mi}^{2}$ ), where the safe yield is exceeded by 566 percent (table 5). In this subbasin, reduction in habitat loss in the stream channel has been documented by the Pennsylvania Fish and Boat Commission. The Commission observed streamflow to be intermittent in the channel that historically has been perennial, and this intermittent streamflow has substantially reduced the game (trout) fish community in the stream (Mike Depew, Pennsylvania Fish and Boat Commission, written commun., 2010). Even though the

Table 5. Summary of water withdrawals, discharges, and screening indicators from the Water Analysis Screening Tool (WAST) for stream sites in the Laurel Hill Creek Basin, southwestern, Pennsylvania, 2009.

[mi² ${ }^{2}$ square miles; ISC, initial screening criteria; Mgal/d, million gallons per day; SI, screening indicator; \%, percent]

\begin{tabular}{|c|c|c|c|c|c|c|c|c|}
\hline \multicolumn{9}{|c|}{ Tributaries } \\
\hline Crab Run & 40.0610 & -79.1728 & 4.17 & 0.022 & 0.0136 & 0.000 & 0.008 & 37.26 \\
\hline Shafer Run & 40.0507 & -79.2000 & 4.93 & 0.028 & 0.1895 & 0.000 & -0.161 & -566.18 \\
\hline Kooser Run & 40.0378 & -79.2107 & 4.62 & 0.027 & 0.5347 & 0.227 & -0.281 & -1059.87 \\
\hline Jones Mill Run & 40.0020 & -79.2348 & 4.96 & 0.029 & 0.0189 & 0.000 & 0.010 & 34.77 \\
\hline Spruce Run & 39.9879 & -79.2403 & 2.41 & 0.011 & 0.0058 & 0.000 & 0.005 & 47.54 \\
\hline Fall Creek & 39.9588 & -79.2790 & 12.55 & 0.089 & 0.0051 & 0.000 & 0.084 & 94.26 \\
\hline Lost Creek & 39.9479 & -79.2654 & 4.15 & 0.021 & 0.0084 & 0.004 & 0.016 & 78.33 \\
\hline Whipkey Run & 39.9125 & -79.3057 & 2.55 & 0.011 & 0.0007 & 0.000 & 0.011 & 94.12 \\
\hline Sandy Run & 39.8982 & -79.3235 & 10.76 & 0.073 & 0.0051 & 0.000 & 0.068 & 93.04 \\
\hline Harbaugh Run & 39.9184 & -79.3387 & 2.68 & 0.013 & 0.0003 & 0.000 & 0.013 & 97.57 \\
\hline
\end{tabular}


Table 5. Summary of water withdrawals, discharges, and screening indicators from the Water Analysis Screening Tool (WAST) for stream sites in the Laurel Hill Creek Basin, southwestern, Pennsylvania, 2009._-Continued

$\left[\mathrm{mi}^{2}\right.$, square miles; ISC, initial screening criteria; Mgal/d, million gallons per day; SI, screening indicator; \%, percent]

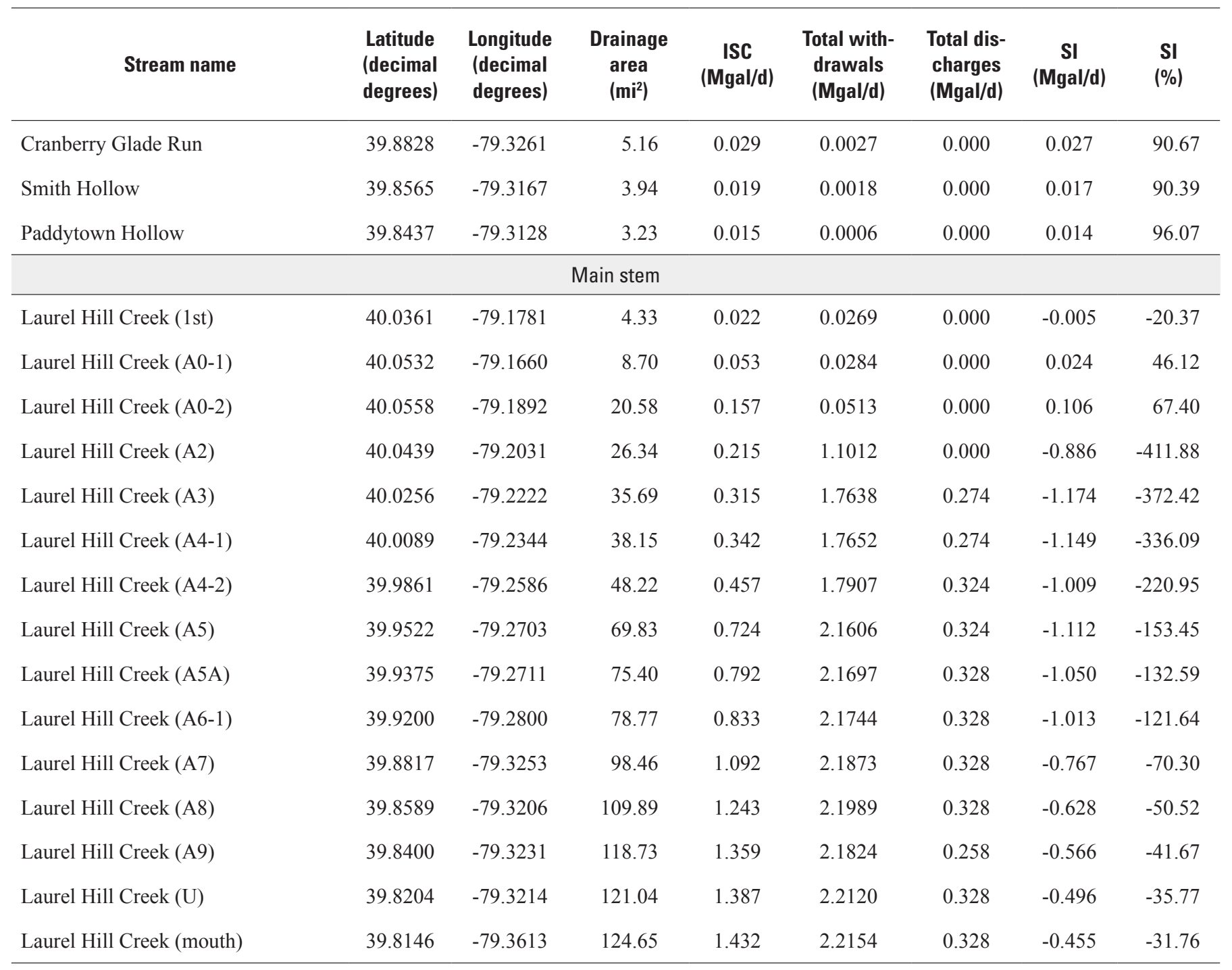

WAST was developed for drainage areas of $15 \mathrm{mi}^{2}$ or greater, results for these subbasins indicate that water use is relatively high for the size of the subbasins, and, in at least one instance (Shafer Run), the streamflow has been visually depleted beyond typical conditions observed in the past.

\section{Simulation of Surface-Water and Groundwater Flow}

A GSFLOW model was developed for the basin as a tool to determine the manner in which future changes in water use and land use could affect the water availability for human consumption and aquatic resources. The calibration of the coupled GSFLOW model necessitated some parameter modification of the uncoupled calibrated models that were developed in
PRMS and MODFLOW. The groundwater flow components of PRMS were replaced by MODFLOW processes in the coupled model. The movement of water from surface processes (as defined by PRMS) through the unsaturated zone to MODFLOW finite-difference cells also affected the water balance for the MODFLOW portion; therefore, parameter adjustments in PRMS and MODFLOW were necessary once the models were coupled in GSFLOW.

\section{Surface Runoff-PRMS Model}

The PRMS model requires an input parameter file that defines the movement of water through the delineated basin. The basin parameterization controls the amount of water lost through evapotranspiration (ET), the amount of water stored in the snowpack (during winter), soil zone, canopy, and land surface, and the amount of water that runs off directly to 
streams. Water that is not lost to ET or direct runoff, and is not stored in the upper soils zone and land surface, is recharged to the groundwater and subsurface reservoirs where it flows out slowly to the stream. The input to PRMS consists of daily air temperature (maximum and minimum) and daily precipitation.

\section{Climate Data}

Eleven weather stations were used to develop the input maximum and minimum daily air temperatures and daily precipitation to PRMS (table 6). The eleven stations were accessed from the cooperative weather station network maintained by the National Climatic Data Center (2008) of the National Oceanic and Atmospheric Administration (http://www.ncdc.noaa.gov/cdo-web/search). No stations were located within the basin boundaries, so the best available network of nearby stations was used. The closest station to the

Table 6. Description of climate stations used for input to the Laurel Hill Creek Basin, southwestern, Pennsylvania, GSFLOW model.

[NAVD 88, North American Vertical Datum of 1988; shading indicates no temperature data available]

\begin{tabular}{|c|c|c|c|c|}
\hline $\begin{array}{l}\text { Weather } \\
\text { station } \\
\text { number }\end{array}$ & $\begin{array}{l}\text { Station } \\
\text { name }\end{array}$ & Latitude & Longitude & $\begin{array}{l}\text { Elevation, } \\
\text { feet above } \\
\text { NAVD } 1988\end{array}$ \\
\hline 361350 & Chalk Hill & $39^{\circ} 51^{\prime} 00^{\prime \prime}$ & $79^{\circ} 34^{\prime} 48^{\prime \prime}$ & 1,980 \\
\hline 361705 & Confluence & $39^{\circ} 48^{\prime} 00^{\prime \prime}$ & $79^{\circ} 22^{\prime} 12^{\prime \prime}$ & 1,490 \\
\hline 361726 & Connellsville & $40^{\circ} 00^{\prime} 00^{\prime \prime}$ & $79^{\circ} 36^{\prime} 00^{\prime \prime}$ & 900 \\
\hline 362108 & Derry & $40^{\circ} 18^{\prime} 00^{\prime \prime}$ & $79^{\circ} 19^{\prime} 48^{\prime \prime}$ & 1,060 \\
\hline 362183 & Donegal & $40^{\circ} 07^{\prime} 48^{\prime \prime}$ & $79^{\circ} 24^{\prime} 00^{\prime \prime}$ & 1,799 \\
\hline 365686 & Meyersdale & $39^{\circ} 46^{\prime} 48^{\prime \prime}$ & $79^{\circ} 02^{\prime} 24^{\prime \prime}$ & 2,000 \\
\hline 366042 & Mount Pleasant & $40^{\circ} 13^{\prime} 12^{\prime \prime}$ & $79^{\circ} 30^{\prime} 00^{\prime \prime}$ & 1,003 \\
\hline 366310 & New Stanton & $40^{\circ} 12^{\prime} 00^{\prime \prime}$ & $79^{\circ} 37^{\prime} 48^{\prime \prime}$ & 950 \\
\hline 367338 & Rector & $40^{\circ} 10^{\prime} 12^{\prime \prime}$ & $79^{\circ} 16^{\prime} 12^{\prime \prime}$ & 1,330 \\
\hline 368244 & Somerset & $40^{\circ} 00^{\prime} 00^{\prime \prime}$ & $79^{\circ} 04^{\prime} 48^{\prime \prime}$ & 2,100 \\
\hline 369050 & Uniontown & $39^{\circ} 54^{\prime} 36^{\prime \prime}$ & $79^{\circ} 43^{\prime} 12^{\prime \prime}$ & 956 \\
\hline
\end{tabular}

basin is in Confluence, Pa., just $1 \mathrm{mi}$ from the southern boundary; the farthest station is in New Stanton, Pa., $21 \mathrm{mi}$ from the northwestern basin boundary. Station elevations range from 950 to 2,100 ft above NAVD 88. Precipitation data were available for all 11 stations for the model period of January 1, 1991, through September 29, 2007. Two of the stations did not have maximum and minimum temperature data for this period. Some stations were missing daily values for the three climatic variables. Estimates for these missing values were necessary to avoid computational errors in model output. Values for the stations with data for a particular day were used to fill in missing gaps.

Solar-radiation data were available for three weather stations at airports (table 7). Data were supplied by the Northeast Regional Climate Center (Keith Eggleston, Northeast

Table 7. Description of solar-radiation stations used for input to the Laurel Hill Creek Basin, southwestern, Pennsylvania, GSFLOW model.

[Latitude and longitude are in degrees, minutes, and seconds]

\begin{tabular}{lcc}
\hline \multicolumn{1}{c}{ Airport } & Latitude & Longitude \\
\hline Pittsburgh, PA & $40^{\circ} 29^{\prime} 46^{\prime \prime}$ & $80^{\circ} 15^{\prime} 24^{\prime \prime}$ \\
& & \\
Morgantown, WV & $39^{\circ} 38^{\prime} 34^{\prime \prime}$ & $79^{\circ} 54^{\prime} 59^{\prime \prime}$ \\
& & \\
\hline & & $70^{\circ} 50^{\prime} 01^{\prime \prime}$ \\
\hline
\end{tabular}

Regional Climate Center, written commun., 2008) in units of langleys. The closest location to the basin boundary was the Johnstown airport (23 mi), and the farthest was the Pittsburgh airport (60 mi). Solar radiation data collected on a continuous daily basis were needed because any missing days would cause problems with modeled evapotranspiration for the basin.

\section{Hydrologic Response Units}

The basin was divided into 718 HRUs (fig. 20) with a mean size of 111 acres. Most of the HRU boundaries were defined primarily by the stream network. Wherever a stream reach intersected another stream reach, a new HRU is defined. Either side of a stream channel is defined as an HRU (hence the two-dimensional approach as defined previously). The density of the drainage network in the Laurel Hill Creek Basin necessitated a large number of HRUs. HRUs in each drainage subbasin that are up-gradient from the perennial stream network were delineated on the basis of land use or slope. 


\section{EXPLANATION}

Hydrologic Response Unit

Base modified from U.S. Geological Survey

1:100,000-scale digital data
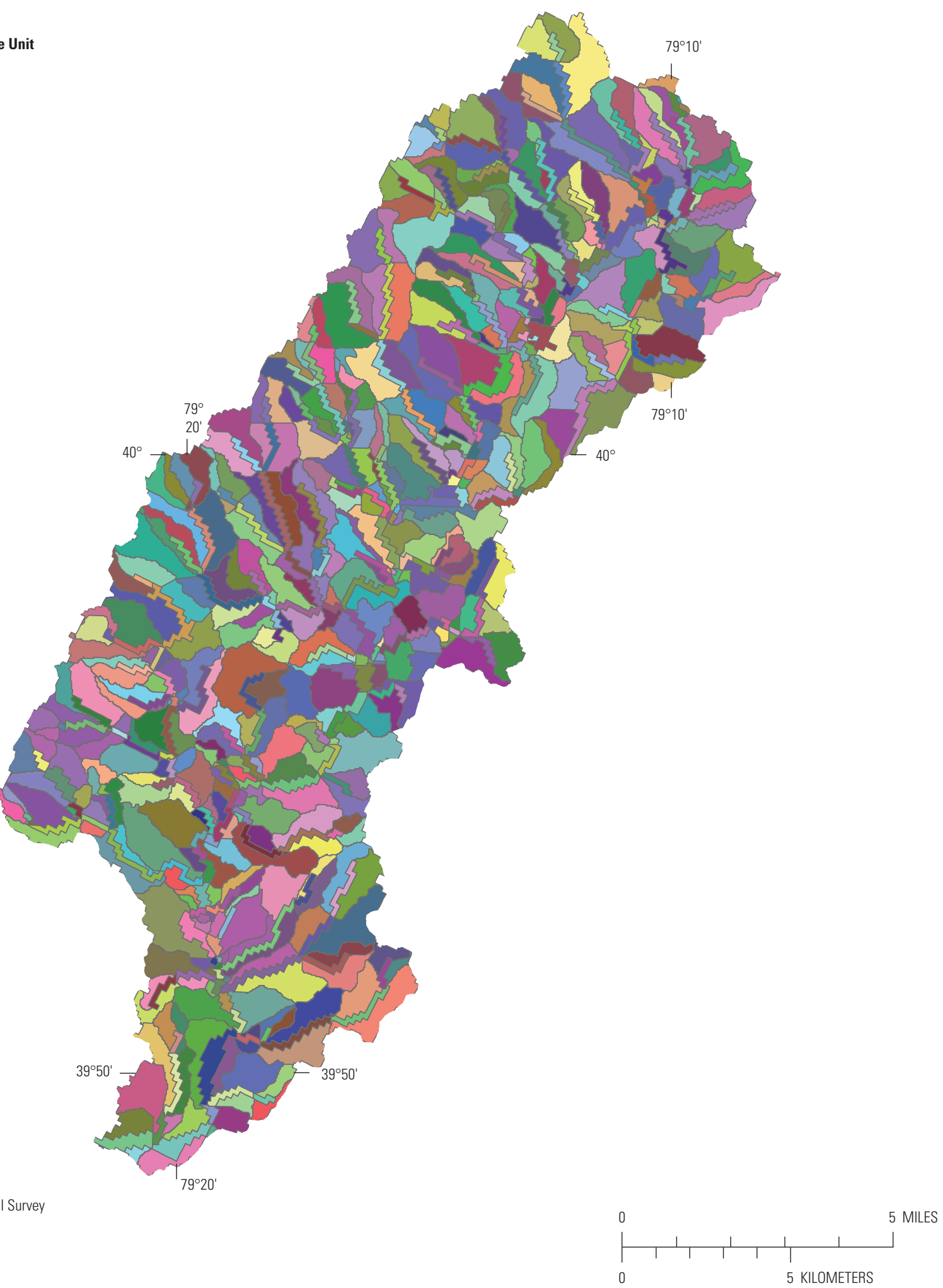

Figure 20. Hydrologic Response Units (HRU) in the Laurel Hill Creek Basin, southwestern, Pennsylvania, generated for the GSFLOW model. 


\section{PRMS Modules}

Eleven different modules were used for the PRMS model prior to integration with MODFLOW in GSFLOW (table 8) for the Laurel Hill Creek Basin. Each module requires specific parameters defined by that particular module. Many parameters are used by more than one PRMS module (table 9 back of report). The number of values for each parameter is dependent on the dimensions for that particular parameter. A dimension defines the number of spatial features or stations or time series values. Physical characteristics of HRUs such as HRU area have the same number of values as the number of HRUs; therefore, variable "hru area" has a dimension equal to the number of HRUs (nhru). Many climatic variables have a dimension equal to the number of months in the year (nmonths). Other parameters that are constant for the entire basin have a dimension equal to one (table 10).

\section{Climatic PRMS Modules}

Six different modules defined climatic variables for the PRMS and subsequently the GSFLOW model for this basin. Two modules (ddsolrad hru and soltab hru) control the distribution of solar radiation to each HRU (table 8). Module ddsolrad_hru adjusts solar radiation values on a monthly basis by using a relation between maximum air temperature and degree days. These monthly adjustments are then taken by the soltab_hru module to distribute potential solar radiation to each HRU (Markstrom and others, 2008).

Precipitation and temperature data were distributed to each HRU using a similar method. Modules precip_dist2 and temp_dist 2 use a lapse rate computed from the number of available stations that is weighted by the inverse of the squared distance between each station and the centroid of each HRU (Markstrom and others, 2008) (table 8). Module temp_dist 2 uses elevation to adjust HRU temperatures, whereas the precip_dist 2 module uses only location relative to precipitation stations to adjust precipitation amounts to HRUs.

The accumulation and melting of snow for each HRU is controlled by the parameterization of variables included within the snowcomp module. Snow depletion curves were separately developed for HRUs with a predominant north or south aspect, and for HRUs classified by elevation. Using the mean elevation of an HRU, elevations were classified as being either above or below 2,350 ft above NAVD 88. The guide for the depletion curve development was Anderson (1973). Actual values used in the model and acceptable ranges for the different parameters are presented in table 11 .

The potet $j h$ module defines evapotranspiration (ET) processes in the basin. This module uses the Jensen-Haise formulation to calculate potential evapotranspiration (Jensen and others, 1969). Air-temperature coefficients are used in the formulation to estimate potential ET (PET). Coefficients were developed on a monthly basis (parameter jh_coef; table 11) and for each HRU (parameter jh_coef_hru). HRU coefficients were generated primarily using elevation. Shevenell (1996) provides PET equations for each month that are functions of elevation; that work was used as an initial starting point to estimate coefficients for the Jensen-Haise formulation. The daily solar radiation data available from the input parameter file are also used in the equation to estimate PET. The precipitation generated by the precip_dist 2 module for the entire model period was 45.6 inches per year. The simulated flow for Laurel Hill Creek at Ursina was about 30 inches per year. Assuming almost a zero change in storage terms within the basin for the entire period, the difference between precipitation inputs and flow should approximate ET losses. Therefore, the coefficients used in the model (see table 11 for actual values) were adjusted along with other parameters that affect simulated ET values to derive annual rates of ET required to balance the water budget - about 15.6 inches. Parameters in the model that affect the simulated amount of water held in the upper soil layers also had a major effect on simulated ET values.

\section{Basin-Characterization PRMS Modules}

The basin module defines the total basin area and has pertinent details for each of the 718 HRUs for the Laurel Hill Creek Basin. This module defines the HRU area, slope, elevation, percent impervious surface, and the type of HRU (land or water) (table 8). The percent impervious surface was generated from an enhanced version of the USGS land cover GIS data (U.S. Geological Survey, 2004).

The intcp module defines the summer and winter cover density and cover type for each of the HRUs. These parameters are based on the USGS land cover data (2004). The cover type for the model is defined as grasses, shrubs, or trees. It is apparent from figure 3 that the predominant land cover for the Laurel Hill Creek Basin is forest. The cover density for winter and summer has a tremendous effect on ET processes and runoff characteristics. Winter cover greatly affects snowpack accumulation and duration. Mean cover density for summer (covden_sum) and winter (covden_win) was determined through GIS processes to equal 0.84 and 0.37 , respectively (table 11).

The soilzone module is a critical aspect of the PRMS model due to the sensitivity of the model to parameters included within this module. Adjustments to specific parameters in this module greatly affect the simulated hydrologic response to precipitation events. The slope of the rise and recession of the hydrograph, along with the recession duration, are affected by numerous parameters defined in this module. The rate and movement of fast and slow interflow from the time water infiltrates the soil until it reaches the stream channel is solely dependent on parameters included within this module. Fast (fastcoef_lin and fastcoef_sq) and slow (slowcoef_lin and slowcoef_sq) interflow terms are defined in this module. Linear (__in) and non linear (_sq) coefficients are available for both fast and slow movement; however, in the Laurel Hill Creek Basin, the _sq terms were set equal to zero for fast and slow interflow (table 11) to 
Table 8. Description of modules used in the GSFLOW model for the Laurel Hill Creek Basin, southwestern, Pennsylvania.

[HRU, Hydrologic Response Unit; shading indicates a GSFLOW module; modules that are not shaded are PRMS modules that were used for the coupled model]

\begin{tabular}{|c|c|}
\hline Module & Description \\
\hline cascade & $\begin{array}{l}\text { Determines the computational order of the HRUs and groundwater reservoirs for routing flow downslope in a cascad- } \\
\text { ing pattern. }\end{array}$ \\
\hline ddsolrad_hru & Distributes solar radiation to each HRU. \\
\hline gsflow_budget & $\begin{array}{l}\text { Calculates a watershed budget for GSFLOW and adjusts the final storage in gravity reservoirs using flows to and from } \\
\text { finite-difference cells at the end of each time step. }\end{array}$ \\
\hline gsflow_prms $2 \mathrm{mf}$ & $\begin{array}{l}\text { Used to integrate the spatial units and transfer dependent variables (model states and fluxes) and volumetric flow rates } \\
\text { between PRMS and MODFLOW. Distributes gravity drainage from gravity reservoirs in the soil zone of PRMS } \\
\text { to finite-difference cells in MODFLOW. The module also distributes surface runoff and interflow from HRUs to } \\
\text { stream segments in MODFLOW. }\end{array}$ \\
\hline gsflow_setconv & $\begin{array}{l}\text { Determines a set of variables that are used in other GSFLOW modules to convert units between PRMS } \\
\text { and MODFLOW during a simulation. }\end{array}$ \\
\hline gsflow_sum & Calculates summary tables of the water balance at the end of each time step. \\
\hline
\end{tabular}

intcp

Calculates the amount of rain and snow that is intercepted by vegetation, the amount of evaporation of intercepted rain and snow, and the amount of net rain and snow throughfall that reaches the soil or snowpack.

potet_jh

Calculates the amount of potential evapotranspiration and determines if a time step is one of active transpiration in an HRU. Uses the Jensen-Haise formulation (Jensen and others, 1969) to calculate potential evapotranspiration.

precip_dist2

Distributes precipitation to each HRU and determines the form of precipitation (rain, snow, or a mixture of both).

Distributes precipitation to HRUs using a lapse rate computed from two or more stations weighted by the inverse of the square of the distance between the centroid of an HRU and each station location.

snowcomp

Initiates development of a snowpack and simulates snow accumulation and depletion processes using an energybudget approach.

soilzone

Calculates inflows to and outflows from the soil zone of each HRU and includes inflows from infiltration, groundwater, and upslope HRUs, and outflows to gravity drainage, interflow, and surface runoff to downslope HRUs.

soltab_hru

Calculates tables of 366 values of potential solar radiation and hours of sunlight for each HRU on the basis of representative slope, aspect, and latitude of each HRU. The module also computes a table of the potential solar radiation at the watershed centroid with a horizontal slope.

srunoff_smidx__ Used to compute surface runoff and infiltration for each HRU. Uses antecedent soil moisture and a non-linear variablecasc source-area method.

temp_dist2

Distributes maximum and minimum temperatures to each HRU using a lapse rate computed from two or more stations weighted by the inverse of the square of the distance between the centroid of an HRU and each station location. 
Table 10. Description of dimension parameters used in the GSFLOW model for the Laurel Hill Creek Basin, southwestern, Pennsylvania.

[HRU, Hydrologic Response Unit]

\begin{tabular}{|c|c|c|}
\hline Dimension & $\begin{array}{l}\text { Number of } \\
\text { values }\end{array}$ & Description \\
\hline ncascade & 1,469 & Number of cascade paths associated with HRUs. \\
\hline ncascdgw & 1,469 & Number of cascade paths associated with PRMS groundwater reservoirs. \\
\hline ndays & 366 & Maximum number of days in a year. \\
\hline ndepl & 4 & Number of snow-depletion curves used for snowmelt calculations. \\
\hline ndeplval & 44 & Number of snow-depletion values for each snow-depletion curve. \\
\hline ngw & 718 & Number of PRMS groundwater reservoirs. (used in PRMS-only simulations) \\
\hline nhru & 718 & Number of HRUs. \\
\hline nhrucell & 25,380 & $\begin{array}{l}\text { Number of unique intersections between gravity reservoirs in PRMS soil zone and MODFLOW finite dif- } \\
\text { ference cells. }\end{array}$ \\
\hline nmonths & 12 & Number of months in a year. \\
\hline nobs & 1 & Number of streamflow-gaging stations. \\
\hline nrain & 11 & Number of measurement stations that measure precipitation. \\
\hline ntemp & 9 & Number of measurement stations that measure air temperature. \\
\hline one & 1 & A constant. \\
\hline
\end{tabular}

simplify the solution as other modelers have done (David Bjerklie, USGS, written commun., 2009). These parameters not only affect the stormflow peaks and shape of a storm hydrograph, but also affect the amount of water available for base flow after storm events. Other parameters in this module have a substantial effect on the simulated hydrograph, including "soil2gw_max," "pref_flow_den," and "ssr2gw_rate." Parameter "soil2gw_max" is the maximum value of soil-water excess routed directly to PRMS groundwater reservoirs. For this model, "soil2gw_max" was set very close to zero (mean for all HRUs was equal to about 0.04 in.; table 11) so that most water during storm events was routed to subsurface recharge (interflow) but not to groundwater reservoirs in PRMS (or MODFLOW finite-difference cells in the coupled model). A decrease in the values for this parameter reduces groundwater flow and increases subsurface flow and surface runoff. Parameter "pref flow den" is the decimal fraction of the soil zone available for preferential flow. A decrease in this parameter causes an increase in ET because more water is available in the upper part of the soil zone to be lost through ET processes. A change in "pref_flow_den" affects the partitioning of subsurface flow into fast and slow components. 
Table 11. Summary of GSFLOW model parameters for Laurel Hill Creek Basin, southwestern, Pennsylvania, including dimensions, number of values specified, units, minimum, maximum, mean, the acceptable range, and default values for each parameter.

[If dimension was equal to one, the mean value is the one value used in the Laurel Hill Creek watershed model; dec. frac., decimal fraction; cal, calories; ${ }^{\circ} \mathrm{C}$, degrees Celsius; >, greater than; ${ }^{\circ} \mathrm{F}$, degrees Fahrenheit; gm, grams; $\mathrm{cm}^{3}$, cubic centimeter]

\begin{tabular}{|c|c|c|c|c|c|c|c|c|}
\hline Parameter & Dimension & $\begin{array}{l}\text { Num- } \\
\text { ber of } \\
\text { values }\end{array}$ & Units & Minimum & Maximum & Mean & Range & Default \\
\hline adjmix_rain & nmonths & 12 & dec. frac. & 0.48 & 1 & 0.80 & $0-3$ & 1 \\
\hline albset_rna & one & 1 & dec. frac. & & & 0.8 & $0-1$ & 0.8 \\
\hline albset_rnm & one & 1 & dec. frac. & & & 0.6 & $0-1$ & 0.6 \\
\hline albset_sna & one & 1 & inches & & & 0.05 & $0.001-1$ & 0.05 \\
\hline albset_snm & one & 1 & inches & & & 0.2 & $0.001-1$ & 0.2 \\
\hline basin_area & one & 1 & acres & & & $79,571.1$ & $0-1 \times 10^{9}$ & 0 \\
\hline basin_solsta & one & 1 & none & & & 2 & $0-3$ & 0 \\
\hline basin_tsta & one & 1 & none & & & 2 & $0-9$ & 1 \\
\hline carea_max & nhru & 718 & dec. frac. & 0.054 & 0.246 & 0.090 & $0-1$ & 0.6 \\
\hline cascade_flg & one & 1 & none & & & 0 & $0-1$ & 0 \\
\hline cascade_tol & one & 1 & acres & & & 1 & $0-99$ & 5 \\
\hline cecn_coef & nmonths & 12 & cal per ${ }^{\circ} \mathrm{C}>0$ & 12 & 12 & 12 & $0-20$ & 5 \\
\hline circle_switch & one & 1 & none & & & 1 & $0-1$ & 1 \\
\hline cov_type & nhru & 718 & none & 1 & 3 & 2.7 & $0-3$ & 3 \\
\hline covden_sum & nhru & 718 & dec. frac. & 0.15 & 1 & 0.84 & $0-1$ & 0.5 \\
\hline covden_win & nhru & 718 & dec. frac. & 0.08 & 0.84 & 0.37 & $0-1$ & 0.5 \\
\hline dday_intcp & nmonths & 12 & degree days & -10 & -10 & -10 & $-60-4$ & -10 \\
\hline dday_slope & nmonths & 12 & degree days $/{ }^{\circ} \mathrm{F}$ & 0.4 & 0.4 & 0.4 & $0.2-0.7$ & 0.4 \\
\hline den_init & one & 1 & $\mathrm{gm} / \mathrm{cm}^{3}$ & & & 0.15 & $0.01-0.5$ & 0.1 \\
\hline den_max & one & 1 & $\mathrm{gm} / \mathrm{cm}^{3}$ & & & 0.6 & $0.1-0.8$ & 0.6 \\
\hline dist_max & one & 1 & $\mathrm{gm} / \mathrm{cm}^{3}$ & & & $1,056,000$ & $1-1 \mathrm{X} 10^{10}$ & $1 \times 10^{10}$ \\
\hline elev_units & one & 1 & none & & & 0 & $0-1$ & 0 \\
\hline emis_noppt & one & 1 & dec. frac. & & & 0.75 & $0.757-1$ & 0.757 \\
\hline epan_coef & nmonths & 12 & none & 1 & 1 & 1 & $0.2-3$ & 1 \\
\hline fastcoef_lin & nhru & 718 & 1/day & 0.024 & 0.190 & 0.108 & $0-1$ & 0.1 \\
\hline fastcoef_sq & nhru & 718 & none & 0 & 0 & 0 & $0-1$ & 0.8 \\
\hline freeh2o_cap & one & 1 & dec. frac. & & & 0.01 & $0.01-0.2$ & 0.05 \\
\hline gvr_cell_id & nhrucell & 25,380 & none & 36 & 22,906 & & $0-22936$ & 1 \\
\hline gvr_cell_pct & nhrucell & 25,380 & dec. frac. & 0 & & & $0-1$ & 0 \\
\hline gvr_hru_id & nhrucell & 25,380 & none & & 1.000 & 0.562 & $0-718$ & 1 \\
\hline gvr_hru_pct & nhrucell & 25,380 & dec. frac. & 0 & 1.000 & 0.028 & $0-1$ & 0 \\
\hline hru_area & nhru & 718 & acres & 1.23 & 580.92 & 110.82 & $0.0-1 \times 10^{10}$ & 1 \\
\hline hru_aspect & nhru & 718 & degrees & 47.06 & 311.94 & 168.70 & $0-360$ & 0 \\
\hline hru_deplcrv & nhru & 718 & none & 1 & 4 & 3.6 & $0-4$ & 1 \\
\hline hru_down_id & ncascade & 1,469 & none & 0 & 715 & & $0-718$ & 0 \\
\hline hru_elev & nhru & 718 & feet & 1,324 & 2,915 & 2,136 & $-1,000-30,000$ & 0 \\
\hline hru_lat & nhru & 718 & degrees & 39.810 & 40.112 & 39.973 & $-90-90$ & 40 \\
\hline hru_pct_up & ncascade & 1,469 & dec. frac. & 0 & 1 & 0.49 & $0-1$ & 1 \\
\hline hru_percent_imperv & nhru & 718 & dec. frac. & 0 & 0.686 & 0.005 & $0-0.999$ & 0 \\
\hline hru_slope & nhru & 718 & dec. frac. & 0.007 & 0.418 & 0.141 & $0-10$ & 0 \\
\hline
\end{tabular}


Table 11. Summary of GSFLOW model parameters for Laurel Hill Creek Basin, southwestern, Pennsylvania, including dimensions, number of values specified, units, minimum, maximum, mean, the acceptable range, and default values for each parameter.-Continued

[If dimension was equal to one, the mean value is the one value used in the Laurel Hill Creek watershed model; dec. frac., decimal fraction; cal, calories; ${ }^{\circ} \mathrm{C}$, degrees Celsius; >, greater than; ${ }^{\circ} \mathrm{F}$, degrees Fahrenheit; gm, grams; $\mathrm{cm}^{3}$, cubic centimeter]

\begin{tabular}{|c|c|c|c|c|c|c|c|c|}
\hline Parameter & Dimension & $\begin{array}{l}\text { Num- } \\
\text { ber of } \\
\text { values }\end{array}$ & Units & Minimum & Maximum & Mean & Range & Default \\
\hline hru_solsta & nhru & 718 & none & 2 & 2 & 2 & $0-3$ & 0 \\
\hline hru_strmseg_down_id & ncascade & 1,469 & none & 0 & 243 & & $0-243$ & 0 \\
\hline hru_type & nhru & 718 & none & 1 & 1 & 1 & $0-3$ & 1 \\
\hline hru_up_id & ncascade & 1,469 & none & 1 & 718 & & $0-718$ & 1 \\
\hline hru_xlong & nhru & 718 & feet & $1,507,759.44$ & $1,578,979.83$ & $1,542,182.94$ & $(-$ to +$) 1 \times 10^{10}$ & 0 \\
\hline hru_ylat & nhru & 718 & feet & $177,801.17$ & $287,060.83$ & $236,645.31$ & $(-$ to +$) 1 \times 10^{10}$ & 0 \\
\hline id_obsrunoff & one & 1 & none & & & 1 & $0-1$ & 0 \\
\hline imperv_stor_max & nhru & 718 & inches & 0.001 & 0.001 & 0.001 & $0-10$ & 0 \\
\hline jh_coef & nmonths & 12 & $1 /{ }^{\circ} \mathrm{F}$ & 0 & 0.008 & 0.004 & $0.005-0.06$ & 0.014 \\
\hline jh_coef_hru & nhru & 718 & ${ }^{\circ} \mathrm{F}$ & 21.205 & 23.013 & 22.090 & $5-20$ & 13 \\
\hline lapsemax_max & nmonths & 12 & ${ }^{\circ} \mathrm{F}$ & -3 & 3 & -0.86 & $-3-3$ & 2 \\
\hline lapsemax_min & nmonths & 12 & ${ }^{\circ} \mathrm{F}$ & -7 & -6 & -6.47 & $-7--3$ & -6.5 \\
\hline lapsemin_max & nmonths & 12 & ${ }^{\circ} \mathrm{F}$ & 2.5 & 3.5 & 3.02 & $-2-4$ & 3 \\
\hline lapsemin_min & nmonths & 12 & ${ }^{\circ} \mathrm{F}$ & -5 & -3 & -3.99 & $-7--3$ & -4 \\
\hline max_psta & one & 1 & none & & & 11 & $2-50$ & 50 \\
\hline max_tsta & one & 1 & none & & & 9 & $2-50$ & 50 \\
\hline maxday_prec & one & 1 & inches & & & 12 & $0-20$ & 15 \\
\hline melt_force & one & 1 & Julian day & & & 10 & $1-366$ & 90 \\
\hline melt_look & one & 1 & Julian day & & & 1 & $1-366$ & 90 \\
\hline mnsziter & one & 1 & none & & & 22 & $1-200$ & 4 \\
\hline $\operatorname{monmax}$ & nmonths & 12 & ${ }^{\circ} \mathrm{F}$ & 73 & 102 & 88 & $0-115$ & 100 \\
\hline monmin & nmonths & 12 & ${ }^{\circ} \mathrm{F}$ & -22 & 40 & 10 & $-60-65$ & -60 \\
\hline mxsziter & one & 1 & none & & & 50 & $2-200$ & 15 \\
\hline potet_sublim & one & 1 & dec. frac. & & & 0.1 & $0.1-0.75$ & 0.5 \\
\hline ppt_rad_adj & nmonths & 12 & inches & 0.02 & 0.02 & 0.02 & $0-0.5$ & 0.02 \\
\hline precip_units & one & 1 & none & & & 0 & $0-1$ & 0 \\
\hline pref_flow_den & nhru & 718 & dec. frac. & 0.033 & 0.111 & 0.072 & $0-1$ & 0 \\
\hline psta_mon & nrain X nmonths & 132 & inches & 2.27 & 5.51 & 3.70 & $0.00001-50$ & 1 \\
\hline psta_xlong & nrain & 11 & feet & $1,415,898.725$ & $1,605,935.466$ & $1,503,451.089$ & $(-$ to +$) 1 \times 10^{10}$ & 0 \\
\hline psta_ylat & nrain & 11 & feet & $165,363.574$ & $356,085.582$ & $259,223.744$ & $(-$ to +$) 1 \times 10^{10}$ & 0 \\
\hline rad_conv & one & 1 & none & & & 1 & $0.1-100$ & 1 \\
\hline rad_trncf & nhru & 718 & dec. frac. & 0.819 & 0.959 & 0.874 & $0-1$ & 0.5 \\
\hline radadj_intcp & one & 1 & degree days & & & 0 & $0-1$ & 1 \\
\hline radadj_slope & one & 1 & degree days $/{ }^{\circ} \mathrm{F}$ & & & 0.5 & $0-1$ & 0 \\
\hline radj_sppt & one & 1 & dec. frac. & & & 0.44 & $0-1$ & 0.44 \\
\hline radj_wppt & one & 1 & dec. frac. & & & 0.5 & $0-1$ & 0.5 \\
\hline radmax & one & 1 & dec. frac. & & & 0.8 & $0.1-1$ & 0.8 \\
\hline rain_mon & nhru X nmonths & 8,616 & inches & 1.843 & 5.440 & 3.583 & $0-50$ & 1 \\
\hline runoff_units & one & 1 & none & & & 0 & $0-1$ & 1 \\
\hline sat_threshold & nhru & 718 & inches & 2.071 & 5.701 & 4.712 & $1-999$ & 999 \\
\hline
\end{tabular}


Table 11. Summary of GSFLOW model parameters for Laurel Hill Creek Basin, southwestern, Pennsylvania, including dimensions, number of values specified, units, minimum, maximum, mean, the acceptable range, and default values for each parameter.-Continued

[If dimension was equal to one, the mean value is the one value used in the Laurel Hill Creek watershed model; dec. frac., decimal fraction; cal, calories; ${ }^{\circ} \mathrm{C}$, degrees Celsius; >, greater than; ${ }^{\circ} \mathrm{F}$, degrees Fahrenheit; gm, grams; $\mathrm{cm}^{3}$, cubic centimeter]

\begin{tabular}{|c|c|c|c|c|c|c|c|c|}
\hline Parameter & Dimension & $\begin{array}{l}\text { Num- } \\
\text { ber of } \\
\text { values }\end{array}$ & Units & Minimum & Maximum & Mean & Range & Default \\
\hline settle_const & one & 1 & dec. frac. & & & 0.5 & $0.01-0.5$ & 0.1 \\
\hline slowcoef_lin & nhru & 718 & 1/day & 0.46 & 0.95 & 0.62 & $0-1$ & 0.015 \\
\hline slowcoef_sq & nhru & 718 & none & 0 & 0 & 0 & $0-1$ & 0.1 \\
\hline smidx_coef & nhru & 718 & dec. frac. & 0.000 & 0.094 & 0.004 & $0.0001-1$ & 0.01 \\
\hline smidx_exp & nhru & 718 & 1/inch & 0.2 & 0.8 & 0.53 & $0.2-0.8$ & 0.3 \\
\hline snarea_curve & ndeplval & 44 & dec. frac. & 0.05 & 1 & 0.45 & $0-1$ & 1 \\
\hline snarea_thresh & nhru & 718 & inches & 0 & 79.55 & 40.59 & $0-200$ & 50 \\
\hline snow_intep & nhru & 718 & inches & 0 & 0.016 & 0.004 & $0-5$ & 0.1 \\
\hline snow_mon & nhru X nmonths & 8,616 & inches & 0 & 1.834 & 0.429 & $0-50$ & 1 \\
\hline snowinfil_max & nhru & 718 & inches/day & 3.506 & 3.525 & 3.519 & $0-20$ & 2 \\
\hline soil_moist_init & nhru & 718 & inches & 3.142 & 9.496 & 6.806 & $0-20$ & 3 \\
\hline soil_moist_max & nhru & 718 & inches & 3.801 & 13.795 & 10.565 & $0.001-20$ & 6 \\
\hline soil_rechr_init & nhru & 718 & inches & 3.064 & 6.401 & 4.785 & $0-10$ & 1 \\
\hline soil_rechr_max & nhru & 718 & inches & 3.450 & 9.236 & 7.401 & $0.001-10$ & 2 \\
\hline soil_type & nhru & 718 & none & 1 & 2 & 1.9 & $1-3$ & 2 \\
\hline soil2gw_max & nhru & 718 & inches & 0.038 & 0.071 & 0.041 & $0-5$ & 0 \\
\hline srain_intcp & nhru & 718 & inches & 0 & 0.05 & 0.044 & $0-5$ & 0.1 \\
\hline ssr2gw_exp & nssr & 718 & none & 1 & 1 & 1 & $0-3$ & 1 \\
\hline ssr2gw_rate & nssr & 718 & 1/day & 0.004 & 0.072 & 0.034 & $0-1$ & 0.1 \\
\hline ssstor_init & nssr & 718 & inches & 0.314 & 2.294 & 1.499 & $0-20$ & 0 \\
\hline szconverge & one & 1 & inches & & & 0.000 & $0-0.1$ & 0 \\
\hline temp_units & one & 1 & none & & & 0 & $0-1$ & 0 \\
\hline tmax_allrain & nmonths & 12 & ${ }^{\circ} \mathrm{F}$ & 36 & 36 & 36 & $0-90$ & 40 \\
\hline tmax_allsnow & one & 1 & ${ }^{\circ} \mathrm{F}$ & & & 20 & $-10-40$ & 32 \\
\hline tmax_index & nmonths & 12 & ${ }^{\circ} \mathrm{F}$ & 50 & 50 & 50 & $-10-110$ & 50 \\
\hline tmax_mo_adj & nhru X nmonths & 8,616 & ${ }^{\circ} \mathrm{F}$ & -2.447 & 3.600 & 1.431 & $-10-10$ & 0 \\
\hline tmin_mo_adj & nhru X nmonths & 8,616 & ${ }^{\circ} \mathrm{F}$ & -2.447 & 3.600 & 1.431 & $-10-10$ & 0 \\
\hline transp_beg & nhru & 718 & month & 4 & 4 & 4 & $1-12$ & 4 \\
\hline transp_end & nhru & 718 & month & 10 & 10 & 10 & $1-12$ & 10 \\
\hline transp_tmax & nhru & 718 & degrees & 350 & 350 & 350 & $0-1,000$ & 500 \\
\hline tsta_elev & ntemp & 9 & feet & 900 & 2000 & 1391 & $-300-30,000$ & 0 \\
\hline tsta_xlong & ntemp & 9 & feet & $1,415,898.725$ & $1,605,935.466$ & $1,499,852.413$ & $(-$ to +$) 1 \times 10^{10}$ & 0 \\
\hline tsta_ylat & ntemp & 9 & feet & $165,363.574$ & $356,085.582$ & $253,832.655$ & $(-$ to +$) 1 \times 10^{10}$ & 0 \\
\hline tstorm_mo & nmonths & 12 & none & 0 & 1 & 0.4 & $0-1$ & 0 \\
\hline wrain_intcp & nhru & 718 & inches & 0 & 0.042 & 0.021 & $0-5$ & 0.1 \\
\hline
\end{tabular}


Parameter "ssr2gw rate" controls the linear rate of gravity drainage from upper soil zones to PRMS reservoirs. Once the model is coupled in GSFLOW, the gravity drainage is to MODFLOW finite-difference cells. Increasing values for "ssr2gw rate" increases groundwater flow and tends to decrease subsurface flow and surface runoff, which subsequently tends to increase the amount of water for base flow and reduce the peak and duration of stormflow events.

Note that the parameters in the soilzone module that were found to have a substantial effect on the simulated hydrograph also had to be modified once PRMS was coupled to MODFLOW in GSFLOW. This is primarily because, in the PRMS-only simulations, groundwater flow is primarily controlled by the parameter "gwflow_coef" in the PRMS module gwflow. The module gwflow controls how fast water moves from the PRMS groundwater reservoirs to the stream. Once coupled, MODFLOW dictates the groundwater-flow component of GSFLOW, and this necessitated the modification of parameter values in the soilzone module. The PRMS gwflow module is not used after PRMS is coupled to MODFLOW.

The module srunoff_smidx_casc computes surface runoff and infiltration for each HRU (table 8). The most important parameters included in this module are "carea_max," "snowinfil_max," "smidx_coef," and "smidx_exp." Two types of runoff occur in the model: Hortonian and Dunnian (Markstrom and others, 2008). Hortonian runoff from pervious parts of each HRU is related to the area in which throughfall and snowmelt exceed the soil-infiltration rate (Markstrom and others, 2008). Dunnian runoff is simulated from the soil zone in an HRU when storage as a volume per unit area in the preferential-flow reservoirs exceeds the depth defined by the saturation minus field-capacity thresholds (Markstrom and others, 2008). The parameter "carea max" defines the maximum area for each HRU (as a decimal fraction of the total area) that could contribute surface runoff. Increasing the value for this parameter increases the surface runoff. The mean value for this parameter was about 0.09 for the basin. The "smidx" parameters are used in the algorithm to determine the amount of runoff from the contributing area. If values for "smidx" parameters are increased, values for "carea_max" would have to be decreased to keep the total amount of surface runoff static. The parameter "snowinfil_max" has a great effect on snowmelt events and the runoff associated with them. "Snowinfil max" defines the daily maximum snowmelt infiltration for each HRU. Decreasing values for this parameter reduces the amount of snow infiltration, thus leading to more surface runoff.

The cascade module determines the computational order of the HRUs and groundwater reservoirs for routing flow downslope. The module was designed to route surface runoff and interflow from upslope HRUs to downslope HRUs (Markstrom and others, 2008). The flow from the upslope HRUs is cascaded to downslope HRUs where it can satisfy soil-zone storage capacities prior to being added as inflow to stream segments or lakes.

\section{Groundwater - MODFLOW Model}

\section{Spatial and Temporal Discretization}

A generalized model of the groundwater flow system was created for the Laurel Hill Creek Basin. The basin was divided into a finite-difference grid with 1 layer, 244 rows, and 94 columns. The extent of the active model grid is shown in figure 21. The layer type is specified as convertible, which means that a layer will automatically convert from confined to unconfined if the water table drops below the top of the layer. Model cells were $150 \mathrm{~m}$ by $150 \mathrm{~m}$ squares in the horizontal dimension. The model grid was constructed with rows oriented $\mathrm{N} 25^{\circ} \mathrm{E}$ to align with the general strike of geologic units in the area. The active cells in the model are coincident with the area covered by HRUs in the PRMS model. Steadystate simulations were made to represent average groundwater levels, recharge, and groundwater discharge for 1991-2007. Changes caused by seasonal variations in recharge or pumping were not simulated in the steady-state MODFLOW model, but were incorporated in the MODFLOW-NWT input used in the coupled GSFLOW model. In the GSFLOW model, groundwater withdrawals, surface-water withdrawals, and discharges to surface water were varied by stress period on a monthly basis.

For this project, the objective of the MODFLOW model was to simulate the generalized interaction of the groundwater system with infiltration from land surface and streams. A more detailed, multi-layer groundwater model would be needed to simulate hydraulic heads and delineate contributing areas to wells in greater detail. Initially, a multi-layer model (8 layers) was developed for this study, but this was found to be very unstable with run to run variations evident with no change in parameterization. A 2 or 3 layer model would provide much better detail of the hydrogeologic framework of the system than a one-layer model; however, the simplified groundwater characterization (one layer model) was found to be necessary if a GSFLOW model was to be developed that would be numerically stable and could simulate the linked groundwater and surface-water flow problem in a reasonable amount of time.

\section{Boundary Conditions}

The elevation of the top of each cell was set to the mean elevation of land surface in the cell as determined from the USGS 30-meter DEM. Land-surface elevations assigned to the model cells ranged from 1,319 to $2,960 \mathrm{ft}$. The bottom of each model cell was set to $350 \mathrm{ft}$ below the land-surface elevation, which corresponded to the approximate lower boundary of the active shallow groundwater flow system (McElroy, 2000). It was assumed that most of the groundwater flow that interacts with streams moves through the upper 350 feet of the aquifer.

The lateral extent of the modeled area was defined with no-flow boundaries. No-flow cells were placed around the perimeter of the modeled area on the topographic divide 


\section{EXPLANATION}

Active model area

Stream grid

Simulated wells

Quarry pit withdrawal

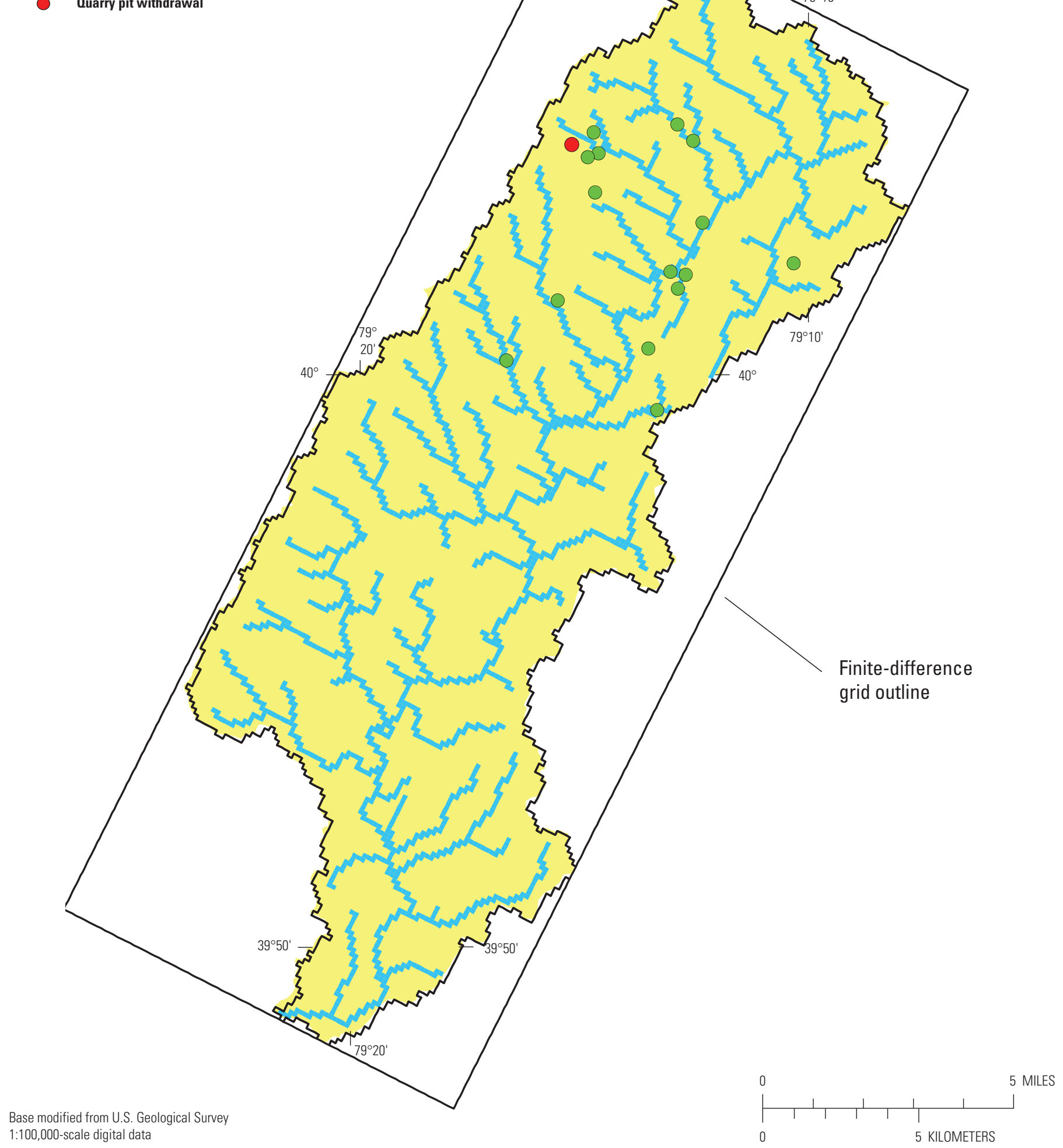

Figure 21. Finite-difference grid with simulated streams, wells, and quarry pit withdrawal in the groundwater-flow model MODFLOW in the Laurel Hill Creek Basin, southwestern, Pennsylvania. 
separating Laurel Hill Creek from adjacent basins. The lateral extent is coincident with that of the PRMS model, which is a necessary condition for linking the models in GSFLOW.

\section{Infiltration from Precipitation}

The MODFLOW-NWT model was constructed by assigning a spatially variable distribution of infiltration to the UZF package that was derived from the output of the PRMS simulations for 1991-2007. The infiltration rate from PRMS was computed as the sum of PRMS fluxes to groundwater (variables "soil_to_gw" and "ssr_to_gw") from each HRU and was assigned to MODFLOW cells on the basis of the percentage of each HRU in the cell. The simulated rate of infiltration from PRMS averaged $16.4 \mathrm{in} / \mathrm{yr}$ for the basin as a whole, which is reasonable when compared to the base flow for the same period of about $18 \mathrm{in} / \mathrm{yr}$ for streamflow records of the USGS streamflow-gaging station 03080000 Laurel Hill Creek at Ursina, Pa., computed by the use of the hydrograph-separation program PART (Rutledge, 1998).

\section{Streams}

Streams were simulated by use of the streamflow-routing (SFR2) package (Niswonger and Prudic, 2005), which allows streams to gain or lose water and accounts for the flow in each stream cell so that losses cannot exceed the simulated streamflow. The locations of streams simulated with SFR2 are shown in figure 21. Streams were represented by 243 segments made up of 2,423 reaches and included the simulation of unsaturated flow beneath the streams. The streambed top elevation in each SFR2 reach (model cell) was set equal to 2 meters less than the nearest elevation derived from the USGS 10-m DEM and was adjusted to ensure that the streambed elevation always decreased downstream. Thickness of the streambed was set to $1 \mathrm{~m}$ for all stream segments. Stream width was varied by segment on the basis of stream order from $3 \mathrm{~m}$ for first-order streams to $7 \mathrm{~m}$ for the lower reaches of Laurel Hill Creek. Hydraulic conductivity of the streambed was assigned a uniform value of 3 feet per day (ft/d). Stream slope for each segment was determined as the difference between the upstream and downstream elevations divided by segment length. Unsaturated-zone properties beneath all stream reaches were set to constant values. The saturated vertical hydraulic conductivity beneath streams was set equal to $3.3 \mathrm{ft} / \mathrm{d}$, and the saturated water content was set equal to 0.011 . Water was added at the upstream end of the stream segments in the SFR2 package to simulate major discharges to surface water and was subtracted to simulate major withdrawals of surface water. Three discharges totaling $0.27 \mathrm{ft}^{3} / \mathrm{s}$ and three withdrawals totaling $1.71 \mathrm{ft}^{3} / \mathrm{s}$ were simulated. Simulated withdrawals and discharges are listed in table 12, and sites are shown in figure 11.

\section{Evapotranspiration}

Evapotranspiration from groundwater was simulated with the UZF package. A uniform potential evapotranspiration rate of $23.4 \mathrm{in} / \mathrm{yr}$ derived from a preliminary simulation from PRMS was used for all model cells. An extinction depth of $5 \mathrm{ft}$ below land surface was assumed. When linked to the GSFLOW model, the potential evapotranspiration from MODFLOW-NWT is replaced by values for each HRU computed by PRMS on the basis of daily climate conditions.

\section{Wells and Drains}

Groundwater withdrawals from 15 wells in the Laurel Hill Creek Basin (table 13; fig. 21) were simulated in the steady-state model by use of the well package in MODFLOW-NWT. All withdrawals from public-supply wells were simulated (regardless of rate) along with withdrawals for commercial, industrial, and agricultural uses that exceeded 10 gallons per minute (gal $/ \mathrm{min}$ ). Average simulated groundwater withdrawals for 1991-2007 from the model are shown in table 13. The total groundwater-withdrawal rate simulated from 15 wells in the Laurel Hill Creek Basin was $528.6 \mathrm{gal} / \mathrm{min}$.

The drain package was used to simulate groundwater draining into the south pit of a quarry at row 49, column 24 of the model (see fig. 21 for actual location). The elevation of the drain was $762 \mathrm{~m}$, which is the approximate water level maintained by the quarry operator.

\section{Aquifer Properties}

Aquifer properties were assigned in the Upstream Weighting (UPW) Package of the steady-state MODFLOW-NWT model. Parameters were used to represent the spatial distribution of hydraulic conductivity for the geologic units according to topographic position. Hydraulic conductivity for all geologic units was assigned a value of 0.08 meters per day $(\mathrm{m} / \mathrm{d})$ in upland areas and $1.0 \mathrm{~m} / \mathrm{d}$ in valleys. The specific yield for upland areas was set at 0.0003 (dimensionless) and for valley settings was set at 0.003 . The greater values were assigned to valley settings because a previous study indicated well yields in Somerset County were greater in valleys than in uplands (McElroy, 2000). The distribution of hydraulic-conductivity values is shown in figure 22 . The ratio of hydraulic conductivities along model columns and along model rows (HANI) was assumed to equal 1.0.

Hydraulic properties of the unsaturated zone were assigned in the UZF Package. Values of saturated vertical hydraulic conductivity were set equal to the hydraulic conductivity for the saturated zone $-0.08 \mathrm{~m} / \mathrm{d}$ for upland areas and $1.0 \mathrm{~m} / \mathrm{d}$ in valleys. 
Table 12. Summary of discharges to, and withdrawals from, surface water simulated in the SFR2 streamflow-routing package of the steady-state groundwater model for the Laurel Hill Creek Basin, southwestern, Pennsylvania.

\begin{tabular}{|c|c|c|c|c|}
\hline \multirow{2}{*}{$\begin{array}{l}\text { Surface-water site } \\
\text { identifier and description }\end{array}$} & \multicolumn{2}{|c|}{ Location in model } & \multicolumn{2}{|c|}{ Rate of discharge or withdrawal } \\
\hline & Row & Column & (cubic meters per day) & (cubic feet per second) \\
\hline \multicolumn{5}{|c|}{ Discharge sites } \\
\hline DISCH04 - outfall & 104 & 48 & 212 & 0.09 \\
\hline DISCH05 - outfall & 131 & 57 & 28 & 0.01 \\
\hline DISCH06 - quarry & 46 & 19 & 409 & 0.17 \\
\hline \multicolumn{5}{|c|}{ Withdrawal sites } \\
\hline WDRW_SP1 - hemlock & 75 & 24 & 133 & 0.05 \\
\hline WDRW_SW1 - gosling lake & 98 & 33 & 171 & 0.07 \\
\hline WDRW_SW2 - laurel hill & 52 & 57 & 3,886 & 1.59 \\
\hline
\end{tabular}

Table 13. Groundwater withdrawals from wells simulated in the MODFLOW_NWT steady-state model for the Laurel Hill Creek Basin, southwestern, Pennsylvania.

\begin{tabular}{lcccc}
\hline \multirow{2}{*}{ Well identifier } & \multicolumn{2}{c}{ Model location } & \multicolumn{2}{c}{ Mean withdrawal rate, 1991-2007 } \\
\cline { 2 - 5 } & Row & Column & (cubic meters per day) & (gallons per minute) \\
\hline Gosling Well & 97 & 32 & 832.2 & 153.8 \\
\hline Shafer Run Well 2 & 35 & 42 & 746.3 & 137.9 \\
\hline Hidden Valley Well 1 & 49 & 30 & 513.4 & 94.9 \\
\hline Shafer Run Well 1 & 37 & 47 & 245.9 & 45.5 \\
\hline SWA Meyer Well (Well 3) & 52 & 56 & 229.1 & 42.3 \\
COMM41 & 56 & 33 & 153.2 & 28.3 \\
\hline AG18 & 50 & 78 & 69.30 & 12.8 \\
\hline PIO orchard well (1) & 67 & 58 & 26.83 & 5.0 \\
\hline NE well 1 & 45 & 27 & 20.18 & 3.7 \\
\hline LHSP Wellhouse 2 & 81 & 36 & 16.82 & 3.1 \\
PIO overflow well 3 & 64 & 55 & 3.37 & 0.6 \\
PIO bathhouse well 2 & 63 & 58 & 1.60 & 0.3 \\
LHSP well4 & 81 & 58 & 1.11 & 0.2 \\
Hidden Valley well 2 & 50 & 28 & 0.80 & 0.1 \\
\hline LHSP well 3 & 92 & 66 & 0.57 & 0.1 \\
\hline
\end{tabular}

\section{MODFLOW Steady-State Calibration}

Hydraulic conductivity values in the MODFLOW-NWT model were adjusted to approximate the mean groundwater levels in 17 wells (site locations in fig. 10) sampled during the groundwater synoptic sampling in 2007. Hydraulic conductivity values initially obtained from the automated parameter-estimation program UCODE-2005 (Poeter and others, 2005) were adjusted by trial and error to arrive at the calibrated values described in section "Aquifer Properties." Low values of estimated hydraulic conductivity from the UCODE-2005 program caused groundwater levels to be higher than land surface in many areas, so it was necessary to manually increase hydraulic conductivity until the water level was lowered. As a result, the simulated water levels were generally lower than observed levels, and for upland wells near basin divides, the model substantially underestimated groundwater levels compared to observed levels. The observed and simulated groundwater levels for this study from each of the 17 wells in the Laurel Hill Creek Basin are given in table 14. The simulated water table is illustrated in figure 23.

The underestimation of groundwater levels in the steady-state model illustrates a limitation of the model. This limitation was caused mostly by the use of a single model 
EXPLANATION

Active model area

Hydraulic conductivity,

in meters per day
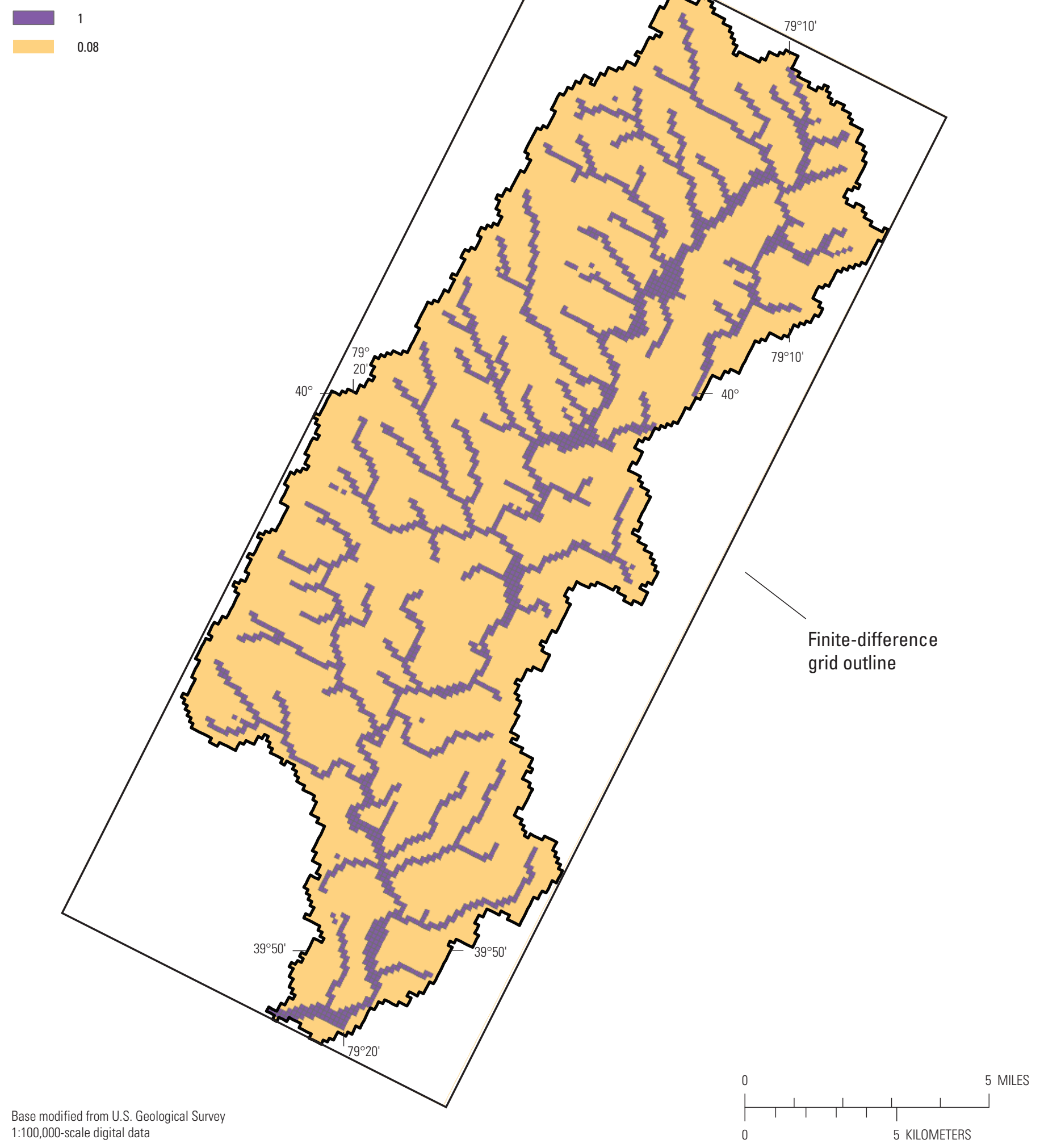

Figure 22. MODFLOW grid with the distribution of hydraulic conductivity values assigned to the steady-state groundwater-flow model for the Laurel Hill Creek Basin, southwestern, Pennsylvania. 
Table 14. Observed (July and October 2007) and simulated water levels at groundwater wells used to adjust the steady state groundwater-flow model (MODFLOW) for the Laurel Hill Creek Basin, southwestern, Pennsylvania.

[USGS, U.S. Geological Survey]

\begin{tabular}{|c|c|c|c|c|c|c|}
\hline \multirow{2}{*}{\multicolumn{2}{|c|}{$\begin{array}{c}\text { USGS } \\
\text { well identifier }\end{array}$}} & \multicolumn{2}{|c|}{ Location in MODFLOW grid } & \multicolumn{3}{|c|}{ Water-level altitude, in meters } \\
\hline & & Row & Column & Observed $^{1}$ & MODFLOW simulated & GSFLOW simulated $^{2}$ \\
\hline FA & 510 & 150 & 6 & 789.72 & 742.14 & 701.68 \\
\hline $\mathrm{SO}$ & 856 & 113 & 52 & 566.21 & 574.37 & 573.53 \\
\hline $\mathrm{SO}$ & 857 & 78 & 68 & 669.24 & 665.06 & 617.51 \\
\hline $\mathrm{SO}$ & 859 & 13 & 65 & 640.50 & 635.59 & 628.80 \\
\hline $\mathrm{SO}$ & 860 & 39 & 55 & 644.24 & 624.68 & 619.86 \\
\hline $\mathrm{SO}$ & $861 a^{3}$ & 37 & 46 & 641.15 & 655.62 & 655.17 \\
\hline $\mathrm{SO}$ & 863 & 81 & 57 & 650.49 & 610.33 & 600.24 \\
\hline $\mathrm{SO}$ & 864 & 139 & 16 & 734.51 & 703.27 & 671.56 \\
\hline SO & 865 & 132 & 36 & 583.76 & 586.21 & 586.60 \\
\hline SO & 867 & 23 & 65 & 657.17 & 623.41 & 617.68 \\
\hline SO & 868 & 117 & 61 & 599.22 & 582.64 & 566.93 \\
\hline $\mathrm{SO}$ & 869 & 224 & 68 & 410.27 & 413.06 & 411.71 \\
\hline $\mathrm{SO}$ & 870 & 97 & 32 & 647.89 & 646.70 & 646.52 \\
\hline
\end{tabular}

${ }^{1}$ Observed water level is the mean of two measurements made in July and October 2007.

${ }^{2}$ Simulated water levels are mean values for the date sampled in July 2007 and for September 29, 2007, which is last day of simulation in GSFLOW model.

${ }^{3}$ SO $861 \mathrm{a}$ and SO $861 \mathrm{~b}$ are two wells owned by a water authority. Water from both these wells was sampled at the water authority building and identified SO 861 as the sampled well. The two wells are near each other in the basin, and water levels were obtained for both wells.

layer to represent the groundwater-flow system of the study area, which is an area of high relief underlain by layered sedimentary rocks that impart a high ratio of horizontal to vertical anisotropy with respect to hydraulic conductivity. In the upland areas, the large vertical hydraulic gradients needed to move groundwater downward cannot be simulated with a one-layer model; however, multi-layer models were found to be numerically unstable (because of problems with cells wetting and drying), so a onelayer model was used. The one-layer model allowed groundwater/surface-water interaction to be simulated but limited the ability to accurately reproduce groundwater levels in upland areas. The two wells (SO 862 and FA 510) with the greatest difference between observed and simulated water levels also had the two highest elevations for any wells sampled (table 14 and appendix 4), with both of the wells along the ridge that is the western boundary of the watershed (fig. 10).

\section{GSFLOW-Linkage of PRMS and MODFLOW}

The linkage of PRMS and MODFLOW in GSFLOW requires calibration of the model even though both PRMS and MODFLOW were independently calibrated prior to the linkage. The main reason for this is that processes defined with PRMS and MODFLOW within the stand-alone calibrations are replaced by coupled processes simulated by GSFLOW. The PRMS gwflow module is not necessary in the coupled model since MODFLOW defines the groundwater processes. The groundwater reservoirs in PRMS are replaced by the finite-difference cells defined within MODFLOW. For MODFLOW, the ET that was used for the stand-alone model was replaced by the daily ET values generated by the potet jh module in PRMS. Specific yields and hydraulic conductivities are defined in MODFLOW. MODFLOW-defined heads 


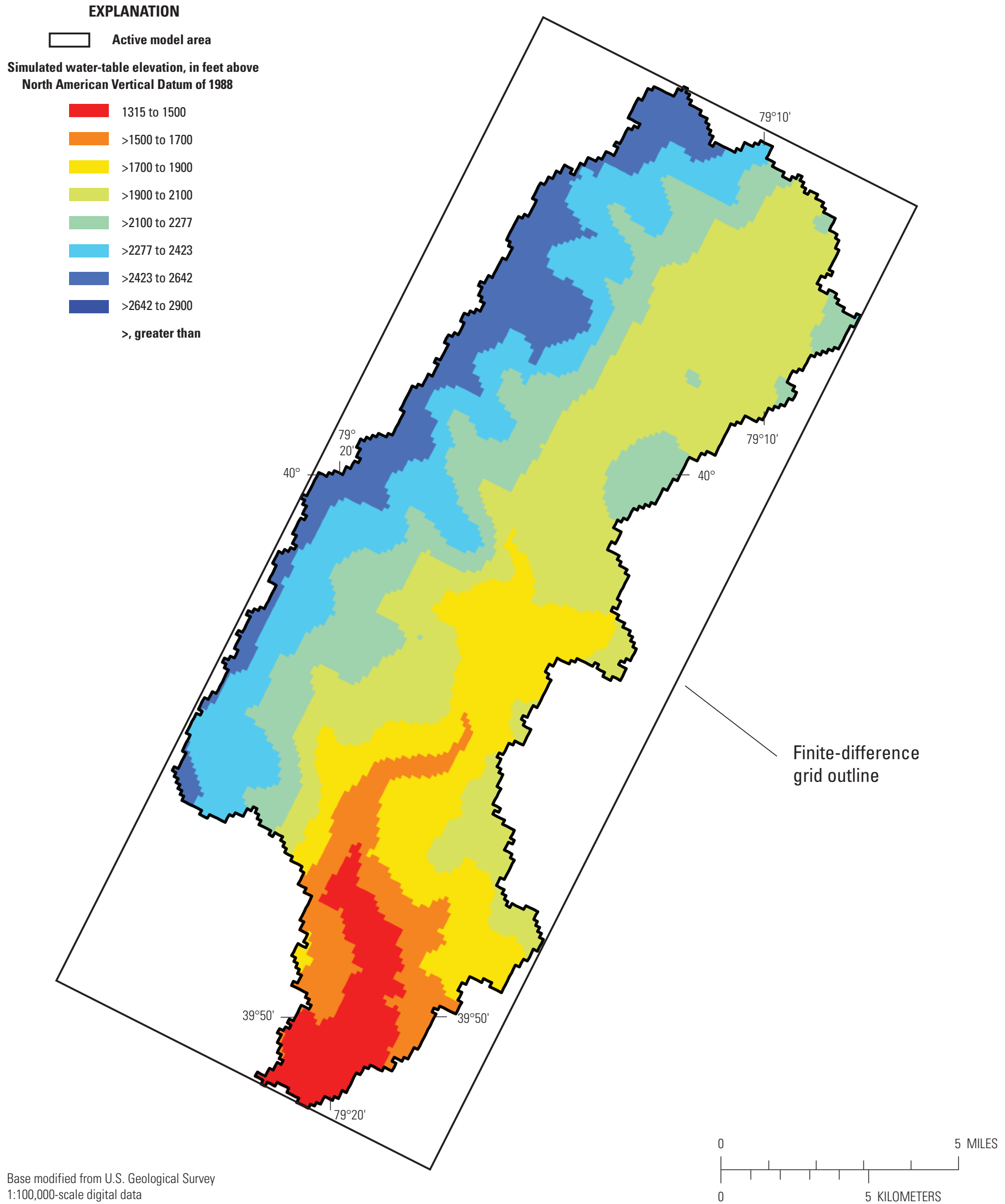

Figure 23. Simulated steady-state water table for the steady-state groundwater-flow model for the Laurel Hill Creek Basin, southwestern, Pennsylvania. 
and hydraulic conductivities for the saturated and unsaturated zones interact with PRMS computations for the soil zone once the models are coupled. In the coupled model, MODFLOW receives daily and spatially distributed gravity drainage from PRMS, replacing the gravity drainage in the MODFLOW-only simulations. MODFLOW tends to reject some of the gravity drainage provided by PRMS soil-zone processes, and this causes a delay in water reaching the stream (R. Steven Regan, USGS, written commun., 2012). The coupled GSFLOW model has three soil zone reservoirs (preferential flow, gravity, and capillary) that occupy the same physical space but represent different processes. Rejected gravity drainage initially is stored in the gravity reservoir where it either stays or moves to one of the other reservoirs, or it becomes interflow or surface runoff (Markstrom and others, 2008). The SFR2 package in MODFLOW computes streamflow in the coupled model; therefore, the streamflow from the PRMS-only simulations is replaced by the MODFLOW generated streamflow.

\section{GSFLOW Model Results}

For calibration of the GSFLOW model, the hydraulicconductivity values were modified from the initial values in MODFLOW, and the parameter values for the soilzone module were modified from the initial values in PRMS. Hydraulic conductivities for upland areas in MODFLOW were increased from $0.08 \mathrm{~m} / \mathrm{d}$ to $1-2 \mathrm{~m} / \mathrm{d}$, whereas the hydraulic conductivity for valleys was reduced from $1 \mathrm{~m} / \mathrm{d}$ to $0.5 \mathrm{~m} / \mathrm{d}$. The vertical hydraulic conductivity for the saturated zone was increased to $3.5 \mathrm{~m} / \mathrm{d}$ for the entire basin. This tended to allow for more rapid downward movement of water in the basin, but once the water flowed into the valleys and near the stream channel, the discharge to the stream network was slowed to allow a more gradual movement of water over time into the stream segments. These changes to MODFLOW parameters were iteratively applied in coordination with changes to PRMS parameters. The PRMS parameters that changed significantly with the coupled model were "pref_flow_den," "slowcoef_lin," and "soil2gw_max." Mean values for "pref_flow_den" (decimal fraction of the soil zone available for preferential flow) decreased from 0.64 in the uncoupled model to 0.07 in the coupled model. Mean values for "slowcoef_lin" (flow routing coefficient for slow interflow) increased from 0.02 to 0.62 in the coupled model, and mean values for "soil2gw_max" (maximum value of soil-water excess routed to groundwater reservoirs) decreased from 0.49 to 0.04 in the coupled model. These changes to PRMS parameters basically reduced the rapid movement of water to streams via fast interflow by reducing the available pore space for fast interflow. This repartitioned water into slow interflow, which mimicked the changes to the MODFLOW parameters.

The GSFLOW calibration of the coupled models for the Laurel Hill Creek Basin was driven primarily by balancing the water budget for the entire period and secondarily by acquiring the best fit to low-flow periods as opposed to periods dominated by stormflow. If the total volume of water modeled for the study period closely approximated (was within about 0.1 percent) the observed streamflow, then hydrograph comparisons between observed and simulated values were manually reviewed to determine whether the change in parameterization improved model simulations. Groundwater levels were not considered in the GSFLOW calibration process. The model was calibrated to streamflow for the time period from January 1, 1991, to September 29, 2007.

\section{Water Budget}

The summations of the observed streamflow at the Laurel Hill Creek at Ursina, Pa., streamflow-gaging station (03080000) and the simulated streamflow for Ursina were very close over the entire modeled period; however, the year to year variations showed a wide range of percent differences between observed and simulated streamflow (table 15). The difference between the observed and simulated streamflow for the entire period was only 0.1 percent. Excluding the 1991 water year due to model start up issues and only 9 months of data, the year to year variations in observed and simulated flow ranged from -27 to 24 percent with 9 of the years having less than a 10-percent difference between observed and simulated streamflows.

The simulated water budget for the basin over the entire period (1991-2007) yielded an annual average estimated precipitation of 45.6 in. This water was allocated on an average annual basis to simulated streamflow (29.5 in.), ET (15.5 in.), water use ( 0.3 in.), and groundwater flow out of the basin (0.1 in.) (table 15). Any remaining water was distributed to storage compartments. The average precipitation estimated for the entire basin was a very good approximation of the regional annual precipitation average. The overall average observed precipitation for the Laurel Hill Creek Basin from 1971 to 2000 was 48 in/yr (PRISM Climate Group, Oregon State University, 2011), so the precipitation for 1991-2007 was estimated to be slightly below the average annual precipitation amount for the area. The observed annual streamflow yield for Laurel Hill Creek at Ursina, Pa., averaged 29.5 inches for 1991-2007. The GSFLOW-simulated annual ET for the basin (15.5 in.) is less than the annual estimated ET values (range of 18-21 in/yr) derived by Sanford and Selnick (2013) for the region. The estimated water use in the basin $(0.3 \mathrm{in} / \mathrm{yr})$ equates to an average annual use of about 690 million gallons per year. The simulated groundwater loss of $0.1 \mathrm{in} / \mathrm{yr}$ is along the basin boundary to the saturated zone. This groundwater loss was consistently evident for many model scenarios.

The simulated flow to the stream was distributed between groundwater, subsurface, and surface runoff. Confounding the percent contributed by each source is the fact that the model determined some of the water getting to the stream was lost from the stream through the streambed (table 15). The groundwater, subsurface, and surface runoff components of the total flow to the stream account for 25,62 , and 13 percent, respectively; therefore, the GSFLOW model has most of the streamflow originating from the subsurface component. Compared to 
Table 15. Observed streamflow and GSFLOW simulated components of the water budget for the Laurel Hill Creek Basin, southwestern, Pennsylvania, 1991-2007. Simulation was for January 1, 1991, to September 29, 2007.

[All units are in inches over the entire watershed, unless otherwise noted; PART, hydrograph separation program used to partition base flow and stormflow; ET, evapotranspiration]

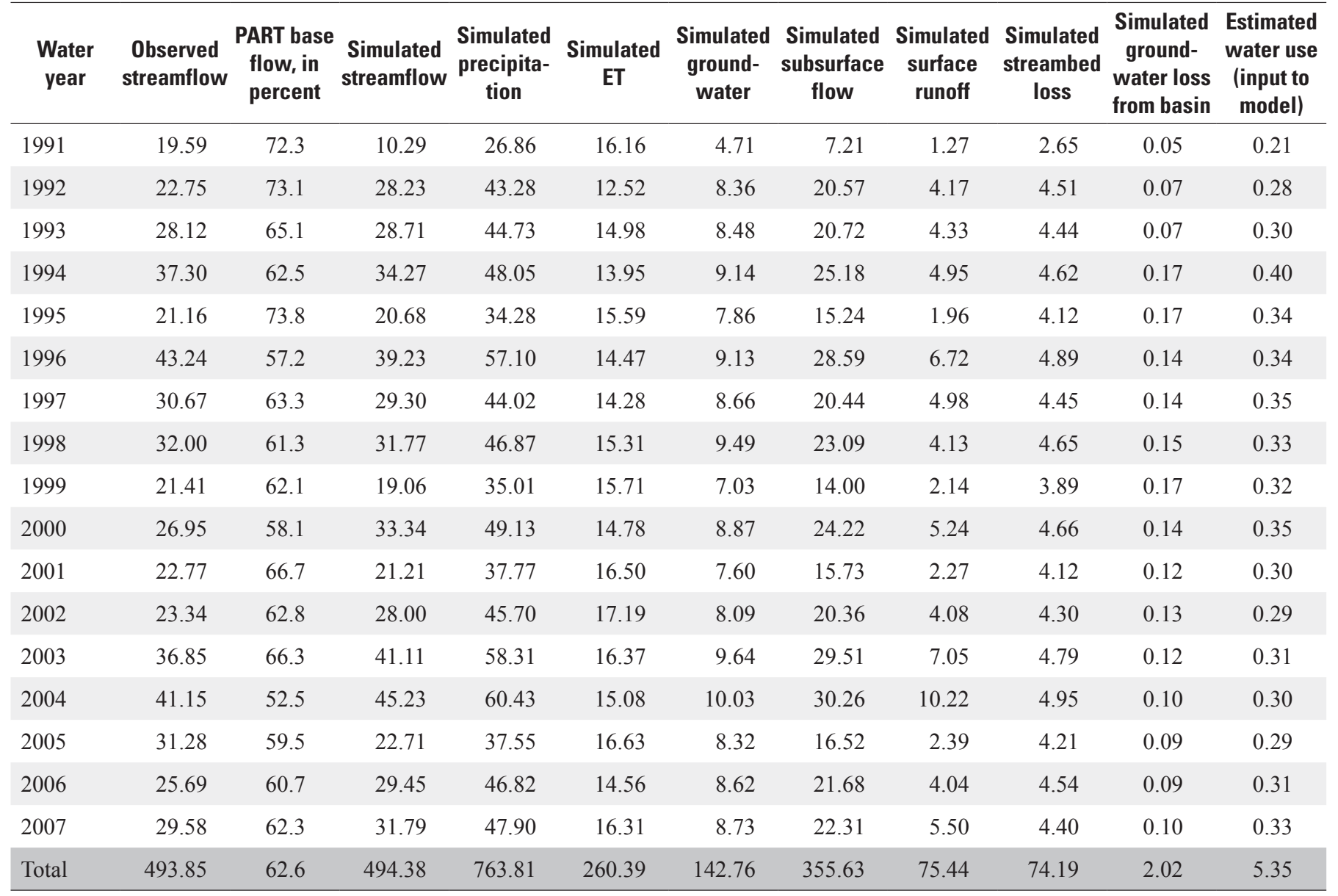

other studies, the percent of subsurface flow for this study was somewhat high. Bent and others (2011) used the Hydrologic Simulation Program - Fortran (HSPF) Precipitation-Runoff model for a New England setting that is not as mountainous or forested as the Laurel Hill Creek Basin and generated a model that estimated the total flow partition of 74,17 , and 9 percent, for groundwater, subsurface flow, and surface runoff, respectively. Bjerklie and others (2010) used PRMS to model the Pomperaug River Basin in Connecticut, which is primarily forested but not as steep as the Laurel Hill Creek Basin. They estimated a total flow partition of 58,27, and 15 percent, for groundwater, subsurface flow, and surface runoff, respectively.

The model partitions the subsurface flow (interflow) into slow flow (micropore) and fast flow (preferential or macropore) components. Slow and fast interflow through the subsurface is routed either directly to the stream or to groundwater. For the Laurel Hill Creek Basin model, most of the simulated subsurface flow that reached the stream was in the form of slow flow. The final model simulation indicated that 97 percent of the subsurface flow was slow flow and only 3 percent was preferential flow. The proportion of slow to fast flow is highly dependent on the parameter "pref flow den." The mean value for "pref_flow_den" for this model is 0.07 , which is a low value considering the acceptable range is $0-1$. A value of 0.07 yields a very low density of preferential flow space in the soil zones in the model. Higher "pref_flow_den" values increase macropore flow with a subsequent decrease in simulated ET. Lower "pref_flow_den" values help to keep water in the upper part of the soil zone, which promotes increased evapotranspiration losses. For this basin, low "pref_flow_den" values were required to keep evapotranspiration losses in the 15-16 in range so that the simulated flow for the entire period was similar in magnitude to the observed flow. The simulated surface runoff was partitioned between Dunnian and Hortonian runoff. Dunnian runoff occurs when storage in the preferential flow reservoirs exceeds saturated conditions and Hortonian runoff occurs when precipitation or snowmelt exceeds soil infiltration rates. Sixty-five percent of the simulated surface runoff was Dunnian runoff, and 35 percent was in the form of Hortonian runoff. Melting snow is an important contributor to groundwater recharge and streamflow in the basin. The simulated snowmelt in the basin generated about 
15 percent of the total streamflow. The snowmelt was transported to the stream via surface-runoff processes or infiltrated the soil and was transmitted as interflow or groundwater base flow to the stream.

\section{Simulated Hydrograph Analysis}

The simulated daily streamflow for GSFLOW and the observed daily streamflow from the streamflow-gaging station at Laurel Hill Creek at Ursina, Pa., are presented for the entire model period (fig. 24). The initial simulated values for the first year of the model period show that the model took a few months to adjust to a relatively steady-state condition related to initial storage terms being developed in PRMS (Markstrom and others, 2008). This "start up" period is typical for the model (R. Steven Regan, USGS, written commun., 2012). The start up period can take as long as a few years, but this is somewhat dependent on the length of the model period and the accuracy of the parameterization. The residual plot (observed minus simulated values; fig. 25) shows that there is a seasonal variation in the residuals. Simulated streamflows for winter months tend to have most of the positive residuals, whereas simulated streamflows for summer months tend to have most of the negative residuals (fig. 25). Modeled ET was reduced to zero for simulated conditions during the winter, so the higher observed flows in winter were not due to ET error. It is likely that the routing of snowmelt water for simulated conditions was being held in the subsurface when more of it should have been routed to the stream via surface runoff. It is not possible to simulate a frozen ice layer in the subsurface that would tend to decrease infiltration and promote more surface runoff. This simulated snowmelt that was held in the subsurface discharged to the stream gradually during the summer months, and this tended to cause simulated flows in summer to exceed observed flows.

The observed streamflow at the Laurel Hill Creek at Ursina, Pa., streamflow-gaging station was analyzed to determine the percentage of base flow for the period from January 1, 1991, through September 29, 2007 (table 15). Daily values were entered as input to the PART program. PART uses streamflow partitioning to estimate a daily record of groundwater discharge from daily values of streamflow. The method designates groundwater discharge to be equal to streamflow on days that fit a requirement of antecedent recession or linearly interpolates groundwater discharge for other days (Rutledge, 1998; U.S. Geological Survey, 2013). The PART program uses a similar method for streamflow partitioning to that of Shirmohammadi and others (1984) in that base flow is generally inclusive of both groundwater and subsurface flow to the stream.

The daily observed streamflow at Ursina, Pa. (station 03080000), for 1991-2007 was separated into predominantly base-flow days and predominantly stormflow days using PART. Once the observed data were classified by flow, the simulated GSFLOW values for the period were merged into the data set. The GSFLOW model runs were calibrated to reduce differences between observed and simulated flows primarily during low-flow periods. Approximately 63 percent of total flow at the Laurel Hill Creek at Ursina, Pa., streamflowgaging station from January 1, 1991, through September 29, 2007, was base flow according to PART results. GSFLOW estimated that 87 percent of the total flow during the period was groundwater and subsurface flow (table 15). Only about 15 percent of the daily values over this period had streamflow that was estimated by PART to be less than 50 percent base flow. So, of the 6,116 days of the model period, only 895 days had daily flow that was estimated to be primarily (greater than 50 percent) stormflow. The percent difference in model residuals tended to decrease with an increase in the percentage of estimated PART base flow using the daily values for the model period (fig. 26). The highest percent differences were evident for days with less than 10 percent base flow, and the lowest percent differences were evident for days with 100 percent base flow (table 16).

The results from the PART analysis of observed and simulated daily streamflow values indicate that the GSFLOW model calibrated for the Laurel Hill Creek Basin for 1991-2007 provided more accurate simulated daily streamflow values for days when observed streamflow for Laurel Hill Creek at Ursina, Pa., was predominantly identified as base flow by PART than for days when observed streamflow had a higher proportion of stormflow as identified by PART. The objective of GSFLOW model development was to provide a tool to simulate changes in streamflow for future wateruse and land-use scenarios. The magnitude of water use in

Table 16. Mean and median percent differences between observed and simulated (GSFLOW) daily streamflows, by percent base-flow estimates, derived by the PART program for the Laurel Hill Creek at Ursina, Pennsylvania, streamflow-gaging station (03080000), January 1, 1991, through September 29, 2007.

\begin{tabular}{lcc}
{$[<$, less than $]$} & \multicolumn{2}{c}{ Percent difference } \\
\hline Percent base flow & Mean & Median \\
\cline { 2 - 3 } & 263 & 117 \\
\hline $0-<10$ & 235 & 70 \\
$10-<20$ & 205 & 71 \\
$20-<30$ & 175 & 71 \\
$30-<40$ & 208 & 65 \\
$40-<50$ & 154 & 63 \\
$50-<60$ & 180 & 69 \\
$60-<70$ & 170 & 69 \\
$70-<80$ & 148 & 64 \\
$80-<90$ & 149 & 62 \\
$90-<100$ & 99 & 55 \\
\hline 100 & &
\end{tabular}



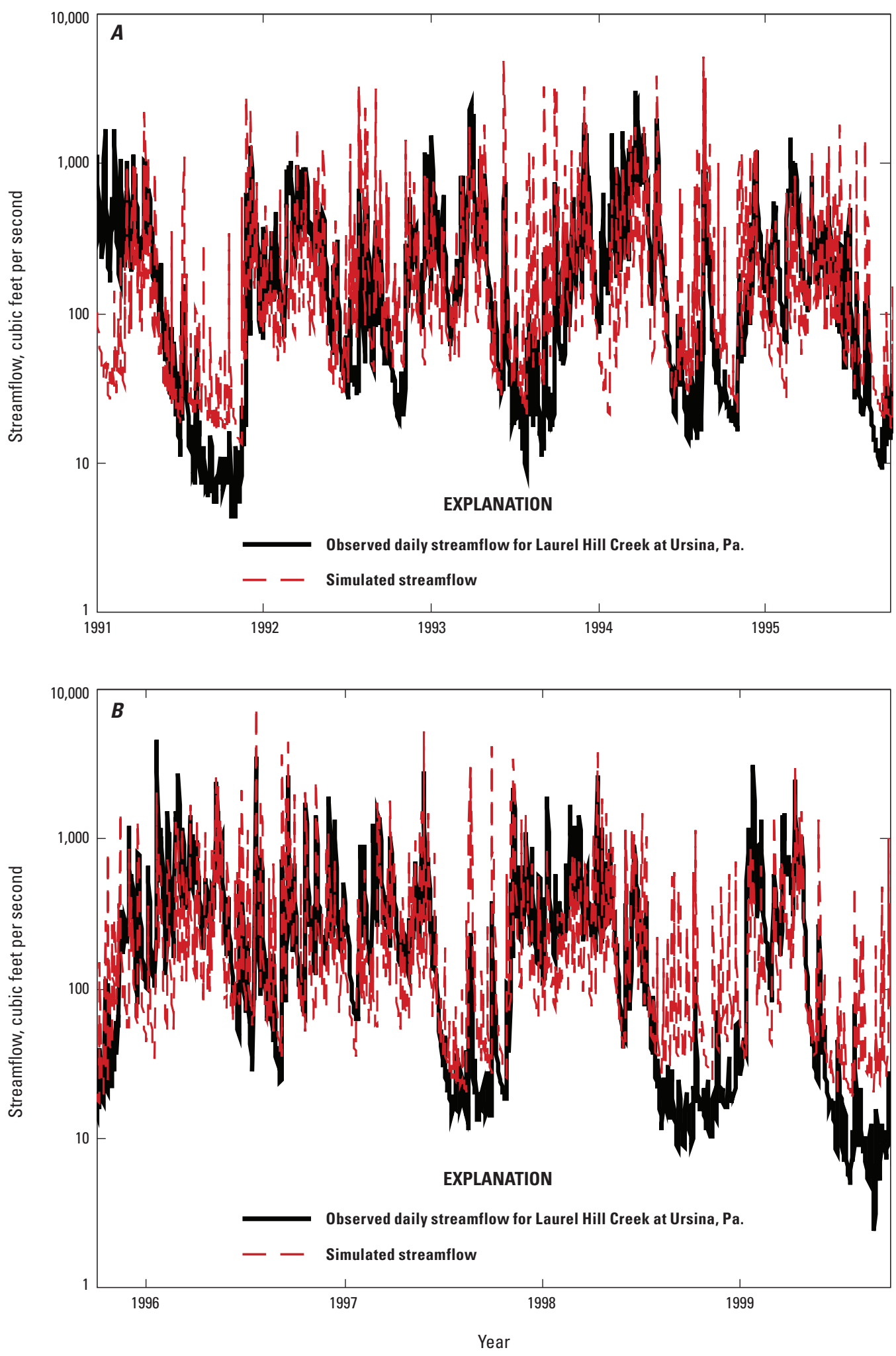

Figure 24. Time series plots of observed daily streamflow at the Laurel Hill Creek at Ursina, Pennsylvania, streamflow-gaging station 03080000 and simulated streamflow from the GSFLOW model for the Laurel Hill Creek Basin, southwestern, Pennsylvania: $A, 1991-95, B$, 1996-99, C, 2000-03, and D, 2004-07. 

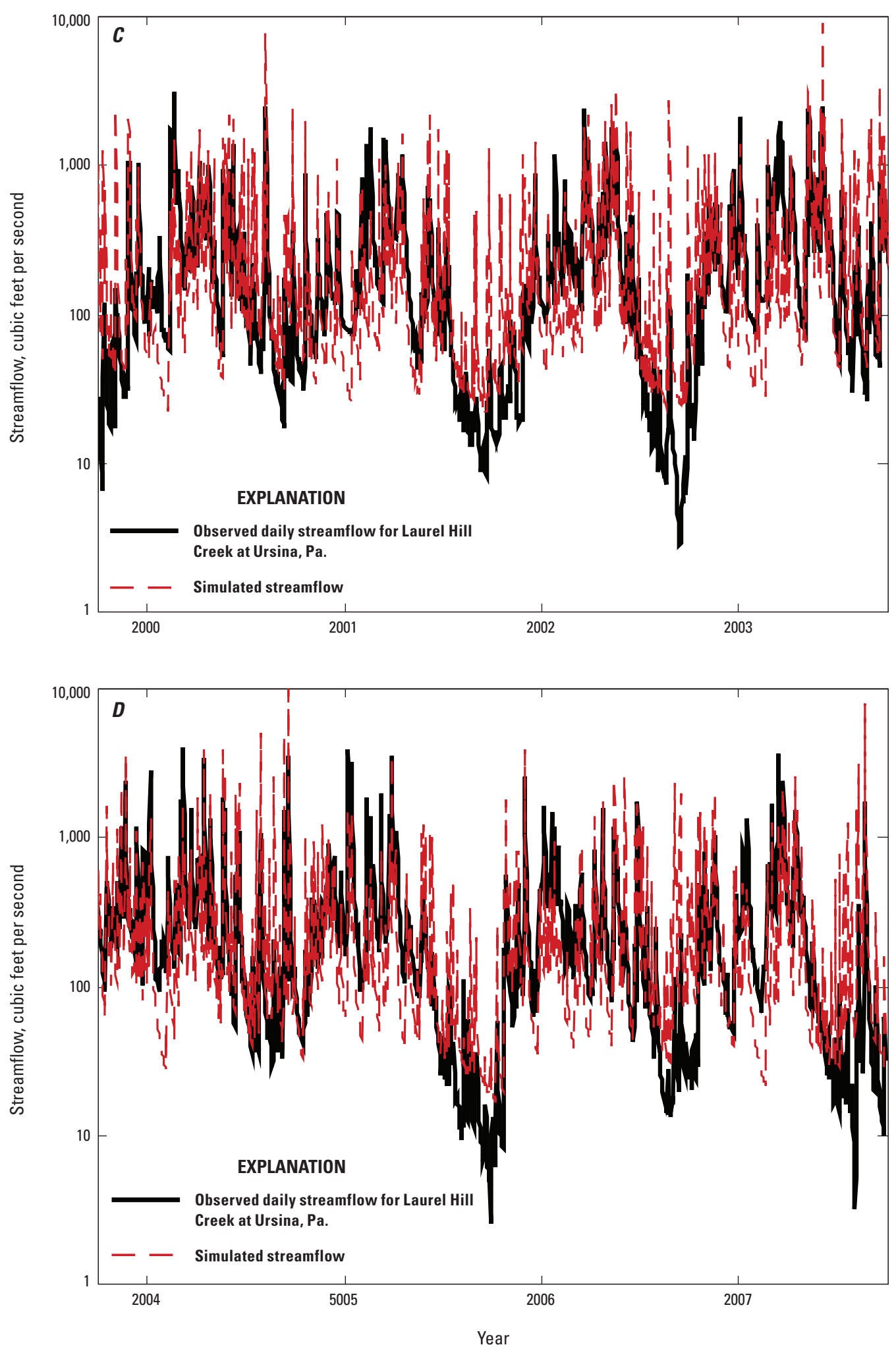

Figure 24. Time series plots of observed daily streamflow at the Laurel Hill Creek at Ursina, Pennsylvania, streamflow-gaging station 03080000 and simulated streamflow from the GSFLOW model for the Laurel Hill Creek Basin, southwestern, Pennsylvania: $A, 1991-95, B$, 1996-99, C, 2000-03, and D, 2004-07.-Continued 


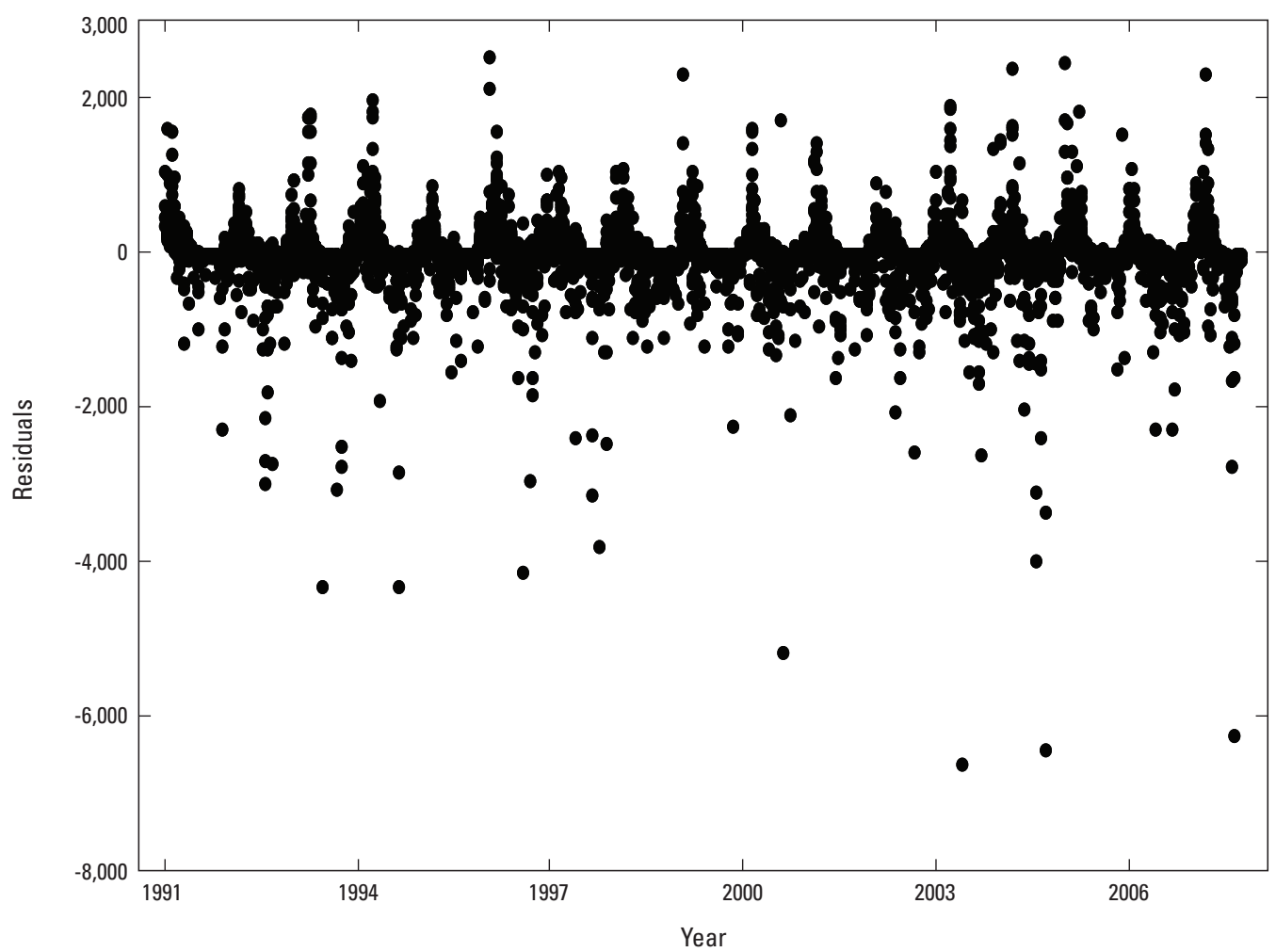

Figure 25. Time series plot of the residuals (observed minus simulated streamflow) for Laurel Hill Creek at Ursina, Pennsylvania, station 03080000 from the GSFLOW model for January 1, 1991, through September 29, 2007.

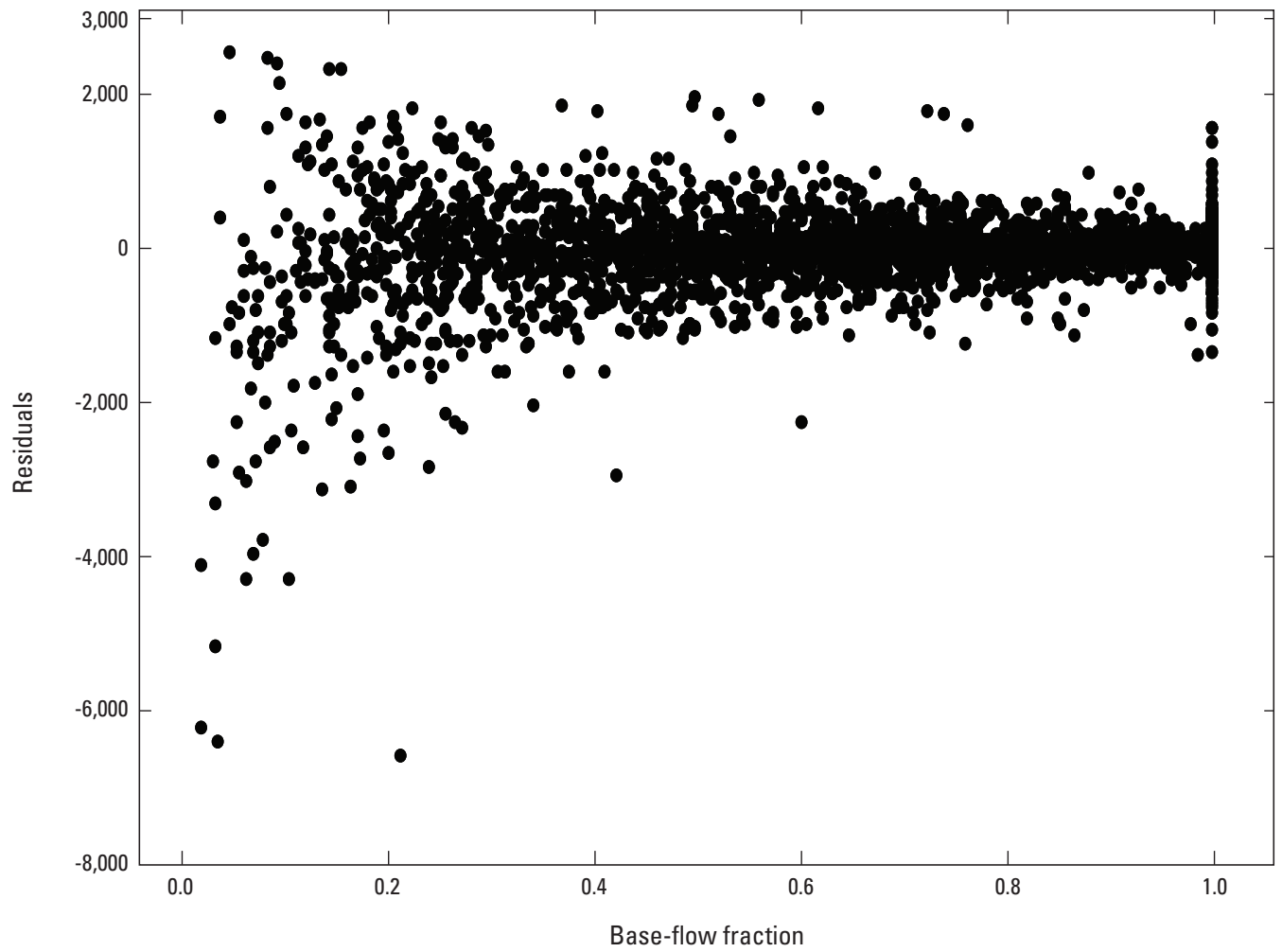

Figure 26. Residuals from the GSFLOW model (observed minus simulated streamflow values) for January 1, 1991, through September 29,2007 , in relation to the daily base-flow fraction, as derived by the hydrograph separation program PART for the Laurel Hill Creek at Ursina, Pennsylvania, streamflow-gaging station (03080000). 
the Laurel Hill Creek Basin is not relevant during periods when streamflow is augmented by storm events or snowmelt; therefore, the emphasis for this study was low-flow conditions. Even though GSFLOW was calibrated with an emphasis on reducing model residuals for low-flow conditions, model accuracy during low-flow conditions could be improved by enhancing the MODFLOW component of the coupled GSFLOW model from a 1-layer approximation of the groundwater flow system to a 2- to 3-layer representation.

\section{GSFLOW Model Results and Water Quality}

The GSFLOW model estimates that the majority of flow in the main stem of Laurel Hill Creek originates from the subsurface component, with the secondary source being groundwater, then surface runoff. This model result seems consistent with the water-quality data collected in 2007 , which indicates that many tributaries along the western half of the basin had low $\mathrm{pH}$ and $\mathrm{SC}$ values, indicating poorly buffered water and relatively short flow paths from precipitation inputs to eventual outflow to a stream channel. Tributaries draining the western ridge retain characteristics of the original acidic precipitation because the runoff and shallow interflow that sustains streamflow moves through highly weathered rock that lacks buffering or acid-forming minerals. The low $\mathrm{SO}_{4}$ concentration in the tributaries (mean concentration of $10 \mathrm{mg} / \mathrm{L}$ ) indicates acidforming minerals are not prevalent in the subsurface weathered materials.

Near-neutral stream samples are present in the main stem of Laurel Hill Creek, and higher alkalinity in the main stem relative to tributary sites indicates that groundwater inflows to the main stem contribute alkalinity. This indicates that the main stem receives a higher proportion of deeper groundwater flow than the tributaries. Mineralization occurs along the deeper flow paths with some of this water eventually discharging to the main stem. The higher specific conductance in the main stem is more reflective of road salt applications, which are transported to the main stem via subsurface/runoff processes.

Another characteristic of the water-quality samples which parallels results from the GSFLOW model are the differences in well and spring water. Groundwater from wells tends to have higher concentration of dissolved ions than springs because of more extensive interactions with aquifer minerals along deeper flow paths to wells, compared to the springs that generally originate from waters that travel along shallow, shorter flow paths. The mean SC for wells and springs sampled in 2007 was 180 and $63 \mu \mathrm{S} / \mathrm{cm}$, respectively. The springs directly contribute to the streamflow in the tributaries and the main stem. One spring sampled in 2007 yields 68 gallons per minute (appendix 4) to the receiving tributary along the western ridge. Springs are numerous in the basin and this input of water to the main stem would be considered a subsurface contributor of water to the main stem.

\section{Summary and Conclusions}

A study was conducted by the U.S. Geological Survey, in cooperation with Somerset County Conservation District, to characterize water quality and quantity, and to simulate groundwater flow, in Laurel Hill Creek Basin in Pennsylvania, which provides recreational opportunities and drinking-water supply to an expanding population in southwestern Pennsylvania. The designation of the basin as a Critical Water Planning Area by the State and a Regional Water Resources Committee resulted in focused efforts to assess water quality and quantity in the basin to reduce the potential for further decline in the viability of the basin as an aquatic resource for humans and wildlife.

The water-quality assessment conducted for this study in 2007 showed that high chloride $(\mathrm{Cl})$ concentrations (near or exceeding the 250 milligrams per liter $(\mathrm{mg} / \mathrm{L})$ drinking-water threshold) in Clear Run could be attributed to road deicing salts from the Pennsylvania Turnpike (Interstate 76). Immediately downstream from the confluence with Clear Run, $\mathrm{Cl}$ concentrations in the main stem of Laurel Hill Creek were more than $100 \mathrm{mg} / \mathrm{L}$. The $\mathrm{Cl}$ concentrations decreased with distance downstream because of dilution by tributaries and groundwater discharge to the main-stem channel. A secondary water-quality issue was elevated nutrient concentrations compared to regional criteria proposed by the U.S. Environmental Protection Agency to minimize eutrophication. All samples from the main stem of Laurel Hill Creek had total nitrogen $(\mathrm{N})$ concentrations greater than the $0.31 \mathrm{mg} / \mathrm{L}$ criterion for streams in the Central and Eastern Forested Uplands (Ecoregion XI), and those samples from the upper part of the basin also had total phosphorus concentrations greater than or equal to the $0.01 \mathrm{mg} / \mathrm{L}$ criterion for streams. Measured total $\mathrm{N}$ concentrations in the upper part of the main stem of Laurel Hill Creek were as high as $1.42 \mathrm{mg} / \mathrm{L}$, most likely caused by agricultural activities. Tributary subbasins (Kooser Run, $3.45 \mathrm{mg} / \mathrm{L}$ of total $\mathrm{N}$ and Lost Creek, $2.07 \mathrm{mg} / \mathrm{L}$ of total $\mathrm{N}$ in June 2007), which receive wastewater discharges, also had elevated total $\mathrm{N}$ concentrations. Analyses of samples collected from tributaries draining forested subbasins indicate that the bedrock provides limited buffering of acidic precipitation. For example, several samples collected from tributaries (Cole Run, Buck Run, Cranberry Glade Run, and Moore Run) underlain by the Allegheny or Pottsville Formations along the western ridge of the basin had $\mathrm{pH}$ values less than 6.0 and specific conductance less than 50 microsiemens per centimeter at 25 degrees Celsius $\left(\mu \mathrm{S} / \mathrm{cm}\right.$ at $\left.25^{\circ} \mathrm{C}\right)$. Manganese (Mn) was the only water-quality constituent in surface water that exceeded the U.S. Environmental Protection Agency maximum contaminant level or secondary maximum contaminant level (SMCL). Mn concentrations exceeded the SMCL of 50 micrograms per liter $(\mu \mathrm{g} / \mathrm{L})$ in 56 percent of the surface-water samples collected.

Stream-temperature probe data for 2007-10 indicate that the main stem of Laurel Hill Creek did not meet the criteria for a cold-water fishery (CWF) during summer months. The maximum temperature for a cold-water fishery varies from 
15.5 degrees Celsius $\left({ }^{\circ} \mathrm{C}\right.$ ) for June $1-15$ to $18.9{ }^{\circ} \mathrm{C}$ for July 1 through August 31 . The average maximum stream temperatures for June through August at the five sites instrumented with temperature probes exceeded the maximum temperature criteria for a CWF. The average maximum temperatures in June at the five instrumented sites ranged from $19.2^{\circ} \mathrm{C}$ to $22.0^{\circ} \mathrm{C}$, in July from $20.7^{\circ} \mathrm{C}$ to $25.5^{\circ} \mathrm{C}$, and in August from $20.7^{\circ} \mathrm{C}$ to $26.0^{\circ} \mathrm{C}$.

Groundwater samples collected in 2007 showed that geology is an important factor in water quality. Groundwater samples collected in areas underlain by the Mauch Chunk Formation had the highest $\mathrm{pH}$ and alkalinity values; in contrast, groundwater samples collected in wells underlain by the Allegheny and Pottsville Formations had the lowest $\mathrm{pH}$ and alkalinity values. Fifty-two percent of the samples collected from wells exceeded the SMCL for iron (Fe) and Mn. The Allegheny and Pottsville Formations had the highest Fe and Mn concentrations, respectively. Water samples from springs generally had lower concentrations of dissolved ions than the samples from wells.

Measured streamflows during base-flow periods indicate that tributaries draining the western, mostly forested part of the basin yield more water than other tributaries. Water withdrawals for public or private water supplies were not readily evident from measured streamflows. The main stem of Laurel Hill Creek yielded an average flow per unit area of 0.16 cubic feet per second per square mile $\left(\mathrm{ft}^{3} / \mathrm{s} / \mathrm{mi}^{2}\right)$. The average streamflows measured during 2007 at the upper site (03079320) was 0.28 cubic foot per second $(0.18 \mathrm{Mgal} / \mathrm{d})$ and at the lower site (03080000) was 18 cubic foot per second (11.6 Mgal/d). Even though water withdrawals were not readily apparent in measured streamflows, criteria established by the Pennsylvania Department of Environmental Protection (PaDEP) and tested with the Water-Analysis Screening Tool (WAST) indicate that the "safe yield" of water withdrawals from the basin was exceeded by 0.46 million gallons per day (Mgal/d). This is about 32 percent greater than the safe yield for the entire basin. Withdrawals are mainly concentrated in the upper one-half of the basin, and three subbasins have safe yields that were greatly exceeded (withdrawals were more than 500 percent of the safe yield).

A groundwater and surface-water flow model (GSFLOW) was developed for the Laurel Hill Creek Basin as a tool that could be used in the future as water use changes in the basin. The development of a single-layer GSFLOW model had some limitations due to the complexity of the groundwaterflow system of the study area, which is an area of high relief underlain by layered sedimentary rocks that impart a high ratio of horizontal to vertical anisotropy with respect to hydraulic conductivity. In the upland areas, the large vertical hydraulic gradients necessary for downward movement of groundwater could not be simulated with a one-layer model, whereas a multi-layer model would provide the ability to adjust hydraulic conductivities for different layers of the system. Another limitation of the GSFLOW model is the computational time step of one day. This problem primarily affects simulated flow near the land surface which generally changes at a faster time step than subsurface flows. Consequently, the daily time step may result in errors due to time averaging for simulated components of the system, such as surface runoff, infiltration, interflow, streamflow, and streambed leakage. For this reason, it was deemed more critical that the simulated water balance be representative of the observed water balance as opposed to simulating storm hydrographs that match observed hydrographs.

The GSFLOW model for the Laurel Hill Creek Basin was calibrated using streamflow data collected for Laurel Hill Creek at Ursina, Pa., from 1991 to 2007 . Net water withdrawals decreased from 2.01 to $1.93 \mathrm{Mgal} / \mathrm{d}$ from 2003 to 2009 with surface-water withdrawals decreasing by $0.14 \mathrm{Mgal} / \mathrm{d}$. Since 2009, water from a nearby reservoir outside the basin has been accessible to water suppliers in the basin to augment water supply that was previously withdrawn from the Laurel Hill Creek Basin. Such a change in water use could be input to the GSFLOW model developed for the basin if that information is needed. Results of the GSFLOW model for the basin developed for 1991-2007 indicate that most of the streamflow in Laurel Hill Creek was derived primarily from subsurface flow or interflow and secondarily from groundwater sources. The vast majority of interflow to the stream was through gradual water movement as opposed to fast flow through macropores. Surface runoff from the GSFLOW model was estimated to account for only 13 percent of the total streamflow from 1991 to 2007. Changes to land use would affect the proportion of streamflow derived from these various sources, and the parameterization of physical attributes in the GSFLOW model can be adjusted for particular Hydrologic Response Units to account for any changes to land use.

\section{References Cited}

American Public Health Association, American Water Works Association, and the Water Environment Federation, 1992, Standards Methods for the Examination of Water and Wastewater (18th ed.): American Public Health Association [variously paginated].

Anderson, E.A., 1973, National Weather Service River Forecast System - Snow accumulation and ablation model: U.S. Department of Commerce, National Oceanic and Atmospheric Administration Memorandum NWS Hydro-17, $217 \mathrm{p}$.

Bent, G.C., Zarriello, P.J., Granato, G.E., Masterson, J.P., Walter, D.A., Waite, A.M., and Church, P.E., 2011, Simulated effects of water withdrawals and land-use changes on streamflows and groundwater levels in the Pawcatuck River Basin, southwestern Rhode Island and southeastern Connecticut: U.S. Geological Survey Scientific Investigations Report 2009-5127, 254 p., http://pubs.usgs.gov/ $\operatorname{sir} / 2009 / 5127$. 
Berg, T.M., Edmunds, W.E., Geyer, A.R., and others, comps., 1980, Geologic map of Pennsylvania (2d ed.): Pennsylvania Geological Survey, 4th ser., Map 1, scale 1:250,000, 3 sheets, https://mrdata.usgs.gov/geology/state/map.html.

Bjerklie, D.M., Starn, J.J., and Tamayo, Claudia, 2010, Estimation of the effects of land use and groundwater withdrawals on streamflow for the Pomperaug River, Connecticut: U.S. Geological Survey Scientific Investigations Report 20105114, 81 p., http://pubs.usgs.gov/sir/2010/5114.

Commonwealth of Pennsylvania, 2009, Pennsylvania Code, Chapter 93, accessed February 16, 2011, at http://www. pacode.com/secure/data/025/chapter93/chap93toc.html.

Crouse \& Company of Somerset and Kleinschmidt Group, 2005, Laurel Hill Creek River Conservation Plan: Somerset, Pa., and Pittsfield, Maine, DCNR Plan RCP 7-18, 68 p.

Ely, D.M., and Kahle, S.C., 2012, Simulation of groundwater and surface-water resources and evaluation of water-management alternatives for the Chamokane Creek Basin, Stevens County, Washington: U.S. Geological Survey Scientific Investigations Report 2012-5224, 74 p.

ESRI, 2001, ArcInfo Workstation (8.1 ed.): Redlands, Calif., ESRI.

ESRI, 2009. ArcMap 9.2. ESRI: Redlands, Calif., ESRI.

Fishman, M.J., ed., 1993, Methods of analysis by the U.S. Geological Survey National Water Quality Laboratory - Determination of inorganic and organic constituents in water and fluvial sediments: U.S. Geological Survey Open-File Report 93-125, $217 \mathrm{p}$.

Freeze, R.A., and Cherry, J.A., 1979, Groundwater: Englewood Cliffs, N.J., Prentice-Hall, Inc., 604 p.

Geyer, A.R., and Wilshusen, J.P., 1982, Engineering characteristics of the rocks of Pennsylvania: Harrisburg, Pa., Pennsylvania Geological Survey, Fourth Series, 300 p.

Harbaugh, A.W., 2005, MODFLOW-2005, the U.S. Geological Survey modular groundwater model - the groundwater flow process: U.S. Geological Survey Techniques and Methods 6-A16 [variously paginated].

Hem, J.D., 1985, Study and interpretation of the chemical characteristics of natural water: U.S. Geological Survey WaterSupply Paper 2254, 3d ed., 263 p.

Jensen, M.E., Rob, D.C.N., and Franzoy, C.E., 1969, Scheduling irrigations using climate-crop-soil data: National Conference on Water Resources Engineering of the American Society of Civil Engineers, New Orleans, La. [Proceedings], p. 20.
Jones, A.L., and Sroka, B.N., 1997, Effects of highway deicing chemicals on shallow unconsolidated aquifers in Ohio, interim report, 1988-93: U.S. Geological Survey WaterResources Investigations Report 97-4027, 139 p.

Leavesley, G.H., Lichty, R.W., Troutman, B.M., and Saindon, L.G., 1983, Precipitation-runoff modeling system-User's manual: U.S. Geological Survey Water-Resources Investigations Report 83-4238, 207 p.

Mackin Engineering Company, 2010, Laurel Hill Creek Basin Land Use Plan: New Cumberland, Pa., Mackin Engineering Company [variously paginated].

Markstrom, S.L., Niswonger, R.G., Regan, R.S., Prudic, D.E., and Barlow, P.M., 2008, GSFLOW-Coupled Groundwater and Surface-Water Flow Model based on the integration of the Precipitation-Runoff Modeling System (PRMS) and the Modular Groundwater Flow Model (MODFLOW-2005): U.S. Geological Survey Techniques and Methods 6-D1, Chapter 1 of Section D, Groundwater/Surface-Water, Book 6, Modeling Techniques, $240 \mathrm{p}$.

McElroy, T.A., 2000, Groundwater resources of Somerset County, Pennsylvania: Pennsylvania Geological Survey Open-File Report 2000-02, 217 p.

Multi-Resolution Land Characteristics Consortium, 2001, National land cover database, accessed June 23, 2017, at https://www.mrlc.gov/nlcd2001.php.

National Climate Data Center, 2008, Cooperative station data accessed June 1, 2008, at http://www.ncdc.noaa.gov/cdoweb/search.

National Climate Data Center, 2004, Climatography of the United States, No. 20, 1971-2000, accessed July 1, 2011, at http://cdo.ncdc.noaa.gov/climatenormals/clim20/PA.

Niswonger, R.G., Panday, S., and Ibaraki, M., 2011, MODFLOW-NWT, A newton formulation for MODFLOW-2005: U.S. Geological Survey Techniques and Methods 6-A37, $44 \mathrm{p}$.

Niswonger, R.G., and Prudic, D.E.,2005, Documentation of the Streamflow-Routing (SFR2) Package to include unsaturated flow beneath streams - A Modification to SFR1: U.S. Geological Survey Techniques and Methods 6-A13, 48 p.

Niswonger, R.G., Prudic, D.E., and Regan, R.S., 2006, Documentation of the Unsaturated-Zone Flow (UZF1) Package for modeling unsaturated flow between the land surface and the water table with MODFLOW-2005: U.S. Geological Survey Techniques and Methods 6-A19, $62 \mathrm{p}$. 
Pennsylvania Bureau of Topographic and Geologic Survey, Dept. of Conservation and Natural Resources, 2008, Physiographic Provinces, accessed June 23, 2017, at http:/www. pasda.psu.edu/uci/DataSummary.aspx?dataset $=1153$.

Pennsylvania Department of Conservation and Natural Resources, 2003, State Forest Resource Management Plan, draft: Bureau of Forestry, accessed June 23, 2017, at http:// www.dcnr.state.pa.us/cs/groups/public/documents/document/dcnr_20026805.pdf.

Pennsylvania Department of Environmental Protection (PaDEP), 2006a, The Pennsylvania State Water Plan and Act 220 of 2002: 3920-FS-DEP 3155, 2 p.

Pennsylvania Department of Environmental Protection (PaDEP), 2006b, Guidelines for identification of Critical Water Planning Areas: 392-2130-014, 17 p.

Pennsylvania Department of Environmental Protection (PaDEP), 2009, State Water Plan Principles: 3010-BKDEP4222, 82 p.

Pennsylvania Department of Environmental Protection (PaDEP), 2011, Laurel Hill Creek TMDL Youghiogheny River, Somerset County, Pennsylvania, accessed December 19, 2014, at http:/www.dep.state.pa.us/dep/deputate/watermgt/wqp/wqstandards/tmdl/Laurel_Hill_Creek_TMDL.pdf.

Pennsylvania Department of Environmental Protection (PaDEP), 2014, 2014 Pennsylvania Integrated Water Quality Monitoring and Assessment Report, Clean Water Act Section 305(b) Report and 303(d) List, accessed June 23, 2017, at http://files.dep.state.pa.us/Water/Drinking\%20 Water\%20and\%20Facility\%20Regulation/WaterQualityPortalFiles/2014\%20Integrated\%20List/2014_Pennsylvania_Integrated_Water_Quality_Monitoring_and_Assessment_Report.pdf

http://files.dep.state.pa.us/Water/Drinking\%20Water $\% 20$ and $\% 20$ Facility\%20Regulation/WaterQualityPortalFiles/2014\%20Integrated\%20List/2014\%20Streams\%20 Category\%205.pdf

Pennsylvania Department of Transportation, 2009, County boundaries, municipal boundaries, and highways, accessed June 20, 2010, at http://www.pasda.psu.edu/uci/ SearchResults.aspx? originator=Pennsylvania\%20Department $\% 20$ of $\% 20$ Transportation\&Keyword=physiograp hic\%20provinces\&sessionID $=215080256201492314810 \&$ s earchType $=$ originator\&entry $=$ PASDA.

Poeter, E.P., Hill, M.C., Banta, E.R., Mehl, S., and Christensen, S., 2005, UCODE_2005 and six other computer codes for universal sensitivity analysis, calibration, and uncertainty evaluation: U.S. Geological Survey Techniques and Methods 6-A11, 283p.
PRISM Climate Group, Oregon State University, 2011, PRISM climate data, accessed June 30, 2011, at http:// prism.oregonstate.edu.

Ritter, M., 2010, The physical environment: an introduction to physical geography, accessed June 23, 2017, at http://www. earthonlinemedia.com/ebooks/tpe_3e/.

Rutledge, A.T., 1998, Computer programs for describing the recession of groundwater discharge and for estimating mean groundwater recharge and discharge from streamflow data-update: U.S. Geological Survey Water-Resources Investigations Report 98-4148, 43 p.

Sanford, W.E., and Selnick, D.L., 2013, Estimation of evapotranspiration across the conterminous United States using a regression with climate and land cover: Journal of the American Water Resources Association (JAWRA), v. 49, no. 1, p. 217-230.

Sharpe, W.E., DeWalle, D.R., Leibfried, R.T., Dinicola, R.S., Kimmel, W.G., and Sherwin, L.S., 1984, Causes of acidification of four streams on Laurel Hill in southwestern Pennsylvania: Journal of Environment Quality, v. 13, p. 619-631.

Shevenell, L., 1996, Statewide potential evapotranspiration maps for Nevada: University of Nevada at Reno, Mackay School of Mines, Nevada Bureau of Mines and Geology, Report 48, 32 p.

Shirmohammadi, A., Kinsel, W.G., and Sheridan, J.M., 1984, An approximate method for partitioning daily streamflow data: Journal of Hydrology, v. 74, p. 335-354.

SonTek, 2003, Flow tracker handheld ADV (Acoustic Doppler Velocimeter) principles of operation: San Diego, SonTek, Calif., 16 p.

Stuckey, M.H., 2008, Development of the water-analysis screening tool used in the initial screening for the Pennsylvania State Water Plan update of 2008: U.S. Geological Survey Open-File Report 2008-1106, 9 p.

Stuckey, M.H., 2006, Low-flow, base-flow, and mean-flow regression equations for Pennsylvania streams: U.S. Geological Survey Scientific Investigations Report 2006-5130, $84 \mathrm{p}$.

U.S. Department of Agriculture, Natural Resource Conservation Service, 2004a, Soil Survey Geographic (SSURGO) database for Somerset County, Pennsylvania, accessed June 23, 2017, 2008, at https://sdmdataaccess.nrcs.usda.gov/.

U.S. Department of Agriculture, Natural Resource Conservation Service, 2004b, Soil Survey Geographic (SSURGO) database for Westmoreland County, Pennsylvania, accessed June 23, 2017, at https://sdmdataaccess.nrcs.usda.gov/. 
U.S. Department of Agriculture, Natural Resource Conservation Service, 2006, Soil Survey Geographic (SSURGO) database for Fayette County, Pennsylvania, accessed June 23, 2017, at https://sdmdataaccess.nrcs.usda.gov/.

U.S. Census Bureau, 2000, United States Census 2000, accessed October 3, 2007, at http://www.census.gov/main/ www/cen2000.html.

U.S. Environmental Protection Agency (EPA), 2000, Ambient water quality criteria recommendations-Information supporting the development of state and tribal nutrient criteria-Rivers and streams in nutrient ecoregion XI: EPA 822-B-00-020, 20 p.

U.S. Environmental Protection Agency (EPA), 2012, 2012 Edition of the drinking water standards and health advisories: EPA 822-S-12-001, 12 p.

U.S. Environmental Protection Agency (EPA), 2015a, National Recommended Water Quality Criteria, accessed January 30, 2015, at http:/water.epa.gov/scitech/swguidance/standards/ criteria/current/index.cfm.

U.S. Environmental Protection Agency (EPA), 2015b, Secondary Drinking Water Regulations: Guidance for Nuisance Chemicals, accessed May 15, 2015, at http:/water.epa.gov/ drink/contaminants/secondarystandards.cfm.
U.S. Geological Survey, 2004, Land Cover Database, accessed August 5, 2007, at http://landcover.usgs.gov.

U.S. Geological Survey, 2009a, National Hydrography Dataset, accessed July 10, 2010, at http://nhd.usgs.gov/index. html.

U.S. Geological Survey, 2009b, National Elevation Database, accessed October 1, 2010, at http://ned.usgs.gov.

U.S. Geological Survey, 2012, StreamStats, accessed June 1, 2012, at http://water.usgs.gov/osw/streamstats/pennsylvania.html.

U.S. Geological Survey, 2013, PART: A computerized method of base-flow-record estimation, accessed July 1, 2013, at http://water.usgs.gov/ogw/part/.

Viger, R.J., and Leavesley, G.H., 2007, The GIS Weasel user's manual: U.S. Geological Survey Techniques and Methods, book 6, chap. B4, $201 \mathrm{p}$.

Winston, R.B., 2000, Graphical User Interface for MODFLOW, version 4: U.S. Geological Survey Open-File Report 00-315, 27 p.

Yaworski, M., 1983, Soil Survey of Somerset County, Pennsylvania: U.S. Department of Agriculture, Soil Conservation Service, $148 \mathrm{p}$. 
Table 9. Description of parameters used in the coupled GSFLOW model for the Laurel Hill Creek Basin, southwestern, Pennsylvania, and modules that invoke that particular parameter.

[HRU, Hydrologic Response Unit; $\mathrm{ft}^{3} / \mathrm{s}$, cubic feet per second; $\mathrm{m}^{3} / \mathrm{s}$, cubic meters per second]

\begin{tabular}{|c|c|c|}
\hline Parameter & Module & Description \\
\hline adjmix_rain & precip_dist2 & Monthly factor to adjust rain proportion in a mixed rain/snow event. \\
\hline albset_rna & snowcomp & $\begin{array}{l}\text { Decimal fraction of rain in a mixed rain and snow event above which snow } \\
\text { albedo is not reset. (Applied when snowpack is accumulating) }\end{array}$ \\
\hline albset_rnm & snowcomp & $\begin{array}{l}\text { Decimal fraction of rain in a mixed rain and snow event above which snow } \\
\text { albedo is not reset. (Applied when snowpack is melting) }\end{array}$ \\
\hline albset_snm & snowcomp & $\begin{array}{l}\text { Minimum snow fall, in water equivalent, needed to reset snow albedo when } \\
\text { snowpack is melting as a decimal fraction. }\end{array}$ \\
\hline basin_area & basin & Total area of watershed. \\
\hline basin_solsta & ddsolrad_hru & Identifier of measurement station used in computing solar radiation. \\
\hline cascade_flg & cascade & Type of cascade routing. ( $0=$ allow many-to-many; $1=$ only allow one-to-one $)$ \\
\hline cascade_tol & cascade & $\begin{array}{l}\text { Minimum area of upslope HRU for computing cascading flow; cascade area } \\
\text { below which a cascade link is ignored. }\end{array}$ \\
\hline cecn_coef & snowcomp & Monthly convection-condensation energy coefficient. \\
\hline circle_switch & cascade & Switch to check for circles. $(0=$ no check; $1=$ check $)$ \\
\hline cov_type & intcp, snowcomp, soilzone & Vegetation cover type for each HRU. ( $0=$ bare soil; $1=$ grasses; $2=$ shrubs; $3=$ trees $)$ \\
\hline covden_sum & intcp, snowcomp, soilzone & Summer plant canopy density as a decimal fraction of the HRU area. \\
\hline covden_win & intcp, snowcomp, soilzone & Winter plant canopy density as a decimal fraction of the HRU area. \\
\hline dist_max & temp_dist2 & Maximum distance from HRU to include a climate station. \\
\hline elev_units & basin & Units of elevation. $(0=$ feet; $1=$ meters $)$ \\
\hline emis_noppt & snowcomp & Emissivity of air on days without precipitation. \\
\hline epan_coef & intcp & Monthly evaporation pan coefficient. \\
\hline fastcoef_lin & soilzone & Linear flow-routing coefficient for fast interflow. \\
\hline fastcoef_sq & soilzone & Non-linear flow-routing coefficient for fast interflow. \\
\hline freeh2o_cap & snowcomp & $\begin{array}{l}\text { Free-water holding capacity of snowpack expressed as decimal fraction of total } \\
\text { snowpack water equivalent. }\end{array}$ \\
\hline gvr_cell_id & $\begin{array}{l}\text { gsflow_setconv, gsflow_prms } 2 \mathrm{mf} \text {, } \\
\text { gsflow_mf2prms, gsflow_budget }\end{array}$ & MODFLOW (finite-difference) cell associated with a gravity reservoir. \\
\hline gvr_cell_pct & gsflow_setconv, gsflow_prms $2 \mathrm{mf}$ & $\begin{array}{l}\text { Proportion of the MODFLOW (finite-difference) cell area associated with each } \\
\text { gravity reservoir. }\end{array}$ \\
\hline
\end{tabular}
gvr_hru id
soilzone, gsflow_prms2mf, gsflow_ mf2prms, gsflow_budget

Identifier of HRU corresponding to each gravity reservoir. 
Table 9. Description of parameters used in the coupled GSFLOW model for the Laurel Hill Creek Basin, southwestern, Pennsylvania, and modules that invoke that particular parameter.-Continued

[HRU, Hydrologic Response Unit; $\mathrm{ft}^{3} / \mathrm{s}$, cubic feet per second; $\mathrm{m}^{3} / \mathrm{s}$, cubic meters per second]

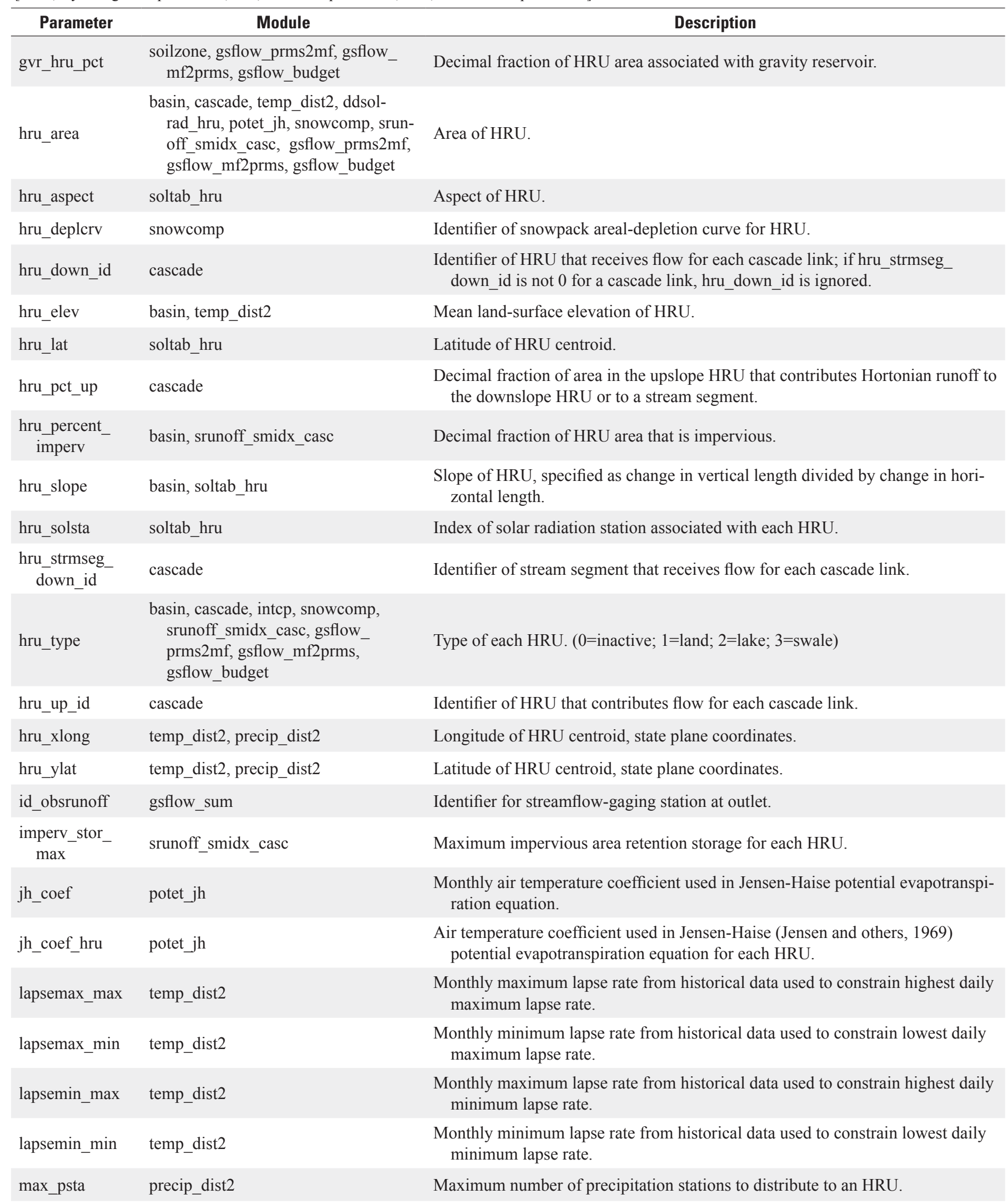


Table 9. Description of parameters used in the coupled GSFLOW model for the Laurel Hill Creek Basin, southwestern, Pennsylvania, and modules that invoke that particular parameter.-Continued

[HRU, Hydrologic Response Unit; $\mathrm{ft}^{3} / \mathrm{s}$, cubic feet per second; $\mathrm{m}^{3} / \mathrm{s}$, cubic meters per second]

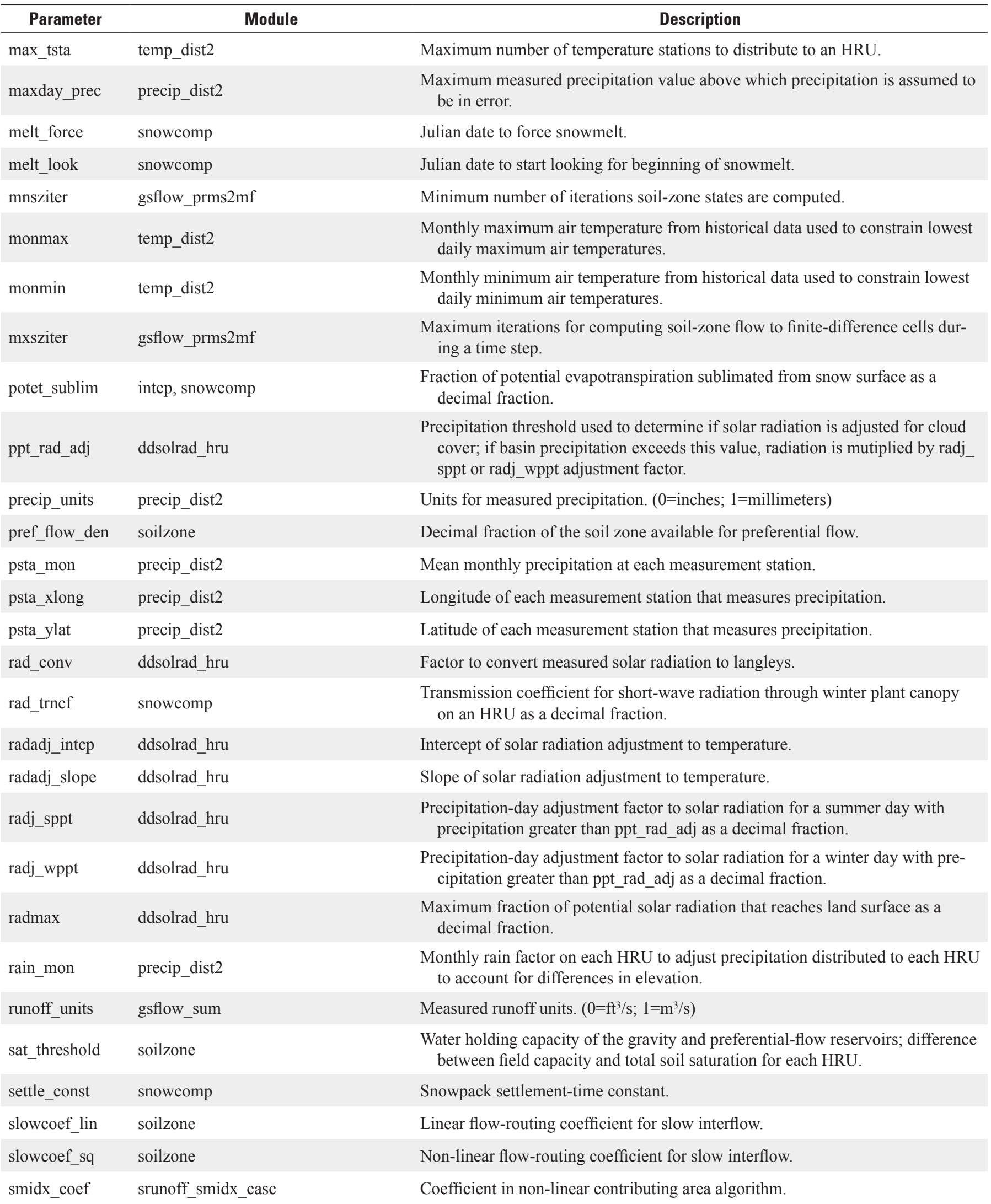


Table 9. Description of parameters used in the coupled GSFLOW model for the Laurel Hill Creek Basin, southwestern, Pennsylvania, and modules that invoke that particular parameter.-Continued

[HRU, Hydrologic Response Unit; $\mathrm{ft}^{3} / \mathrm{s}$, cubic feet per second; $\mathrm{m}^{3} / \mathrm{s}$, cubic meters per second]

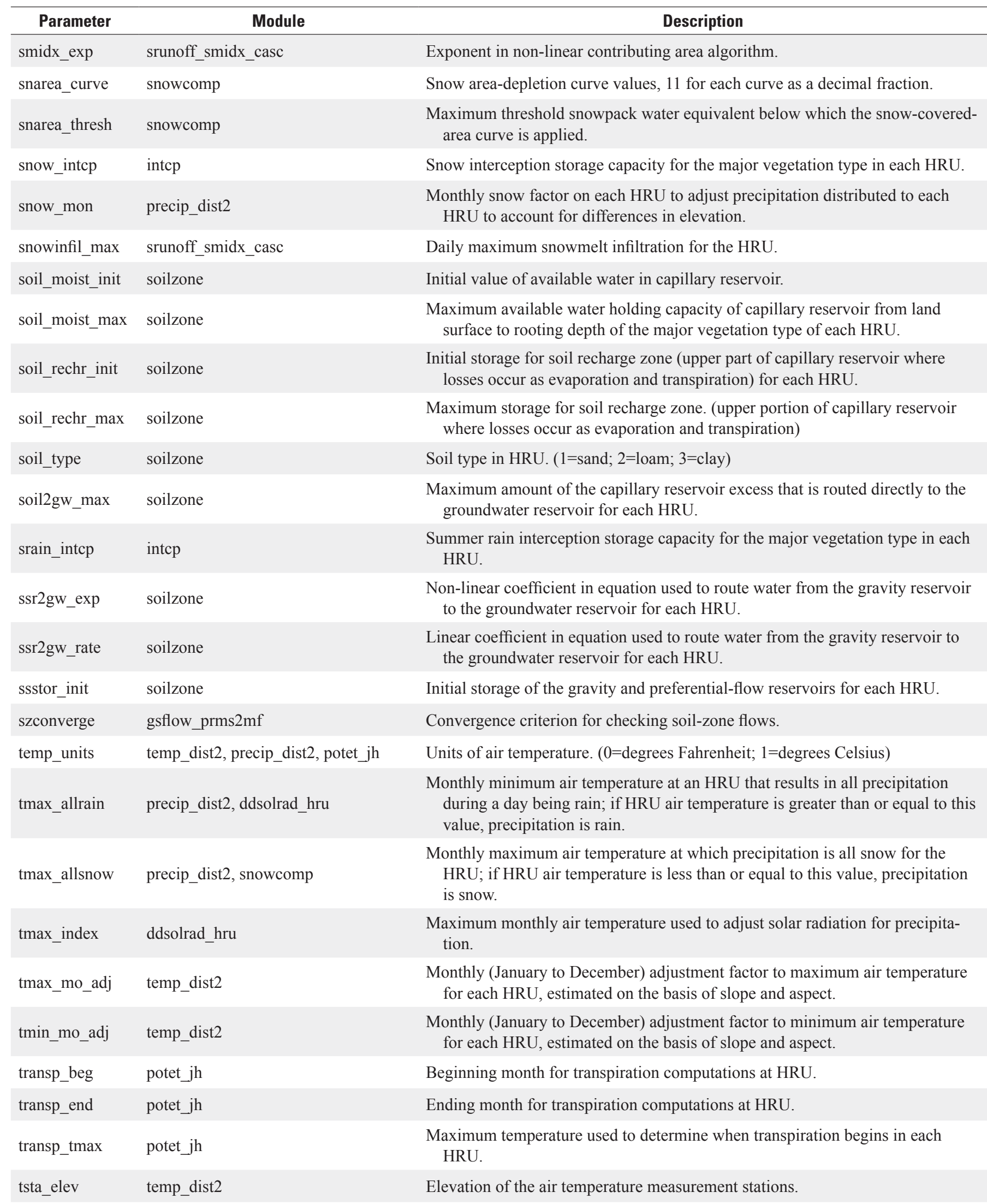


Table 9. Description of parameters used in the coupled GSFLOW model for the Laurel Hill Creek Basin, southwestern, Pennsylvania, and modules that invoke that particular parameter.-Continued

[HRU, Hydrologic Response Unit; $\mathrm{ft}^{3} / \mathrm{s}$, cubic feet per second; $\mathrm{m}^{3} / \mathrm{s}$, cubic meters per second]

\begin{tabular}{lll}
\hline \multicolumn{1}{c}{ Parameter } & Module & \multicolumn{1}{c}{ Description } \\
\hline tsta_xlong & temp_dist2 & Longitude of measurement stations that measure air temperature. \\
tsta_ylat & temp_dist2 & Latitude of measurement stations that measure air temperature. \\
tstorm_mo & snowcomp & $\begin{array}{c}\text { Monthly storm prevalence. }(0=\text { frontal storms prevalent; } 1=\text { convective storms } \\
\text { prevalent })\end{array}$ \\
wrain_intcp & intcp & Winter rain interception storage capacity for the major vegetation type in the \\
\end{tabular}




\section{Appendixes 1, 2, 3, and 4}

\section{Appendix 1}

Concentrations of selected water-quality constituents and values of selected physical characteristics in surface-water samples collected during low-flow conditions in the Laurel Hill Creek Basin, southwestern, Pennsylvania, June and September 2007. (Appendix 1 available online as Excel file at https://doi.org/10.3133/sir20165082)

\section{Appendix 2}

Monthly maximum stream temperature criteria established by the Commonwealth of Pennsylvania (2009), and monthly daily maximum, minimum, and mean stream temperatures for five sites along the main stem of Laurel Hill Creek Basin, southwestern, Pennsylvania, 2007-10.

\section{Appendix 3}

Daily mean streamflow values for station 03080000, Laurel Hill Creek at Ursina, Pennsylvania, July 17, 2007, through July 8, 2010.

\section{Appendix 4}

Concentrations of selected water-quality constituents and values of selected physical characteristics in groundwater samples collected in the Laurel Hill Creek Basin, southwestern, Pennsylvania, summer and fall 2007. (Appendix 4 available online as Excel file at https://doi.org/10.3133/sir20165082) 


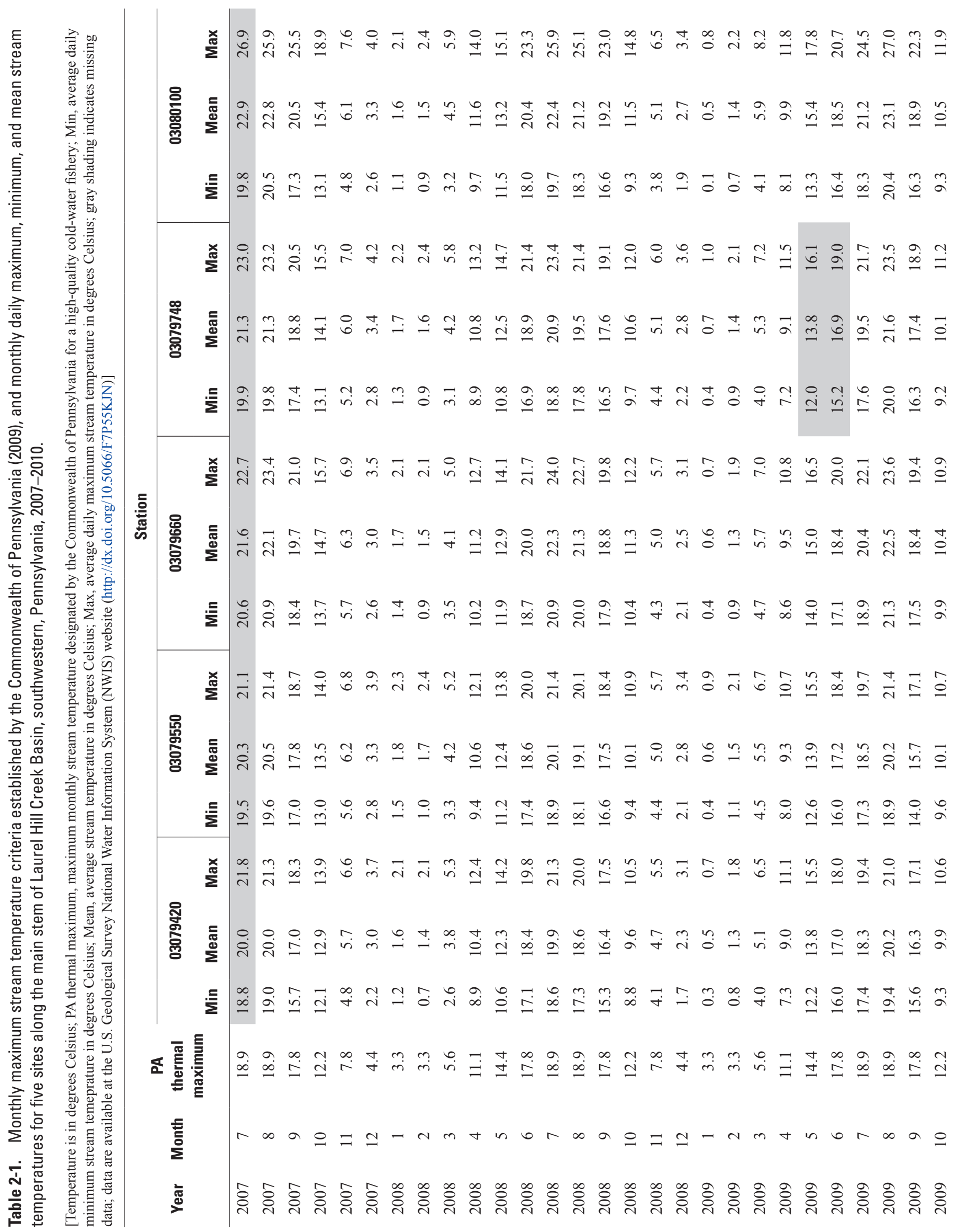




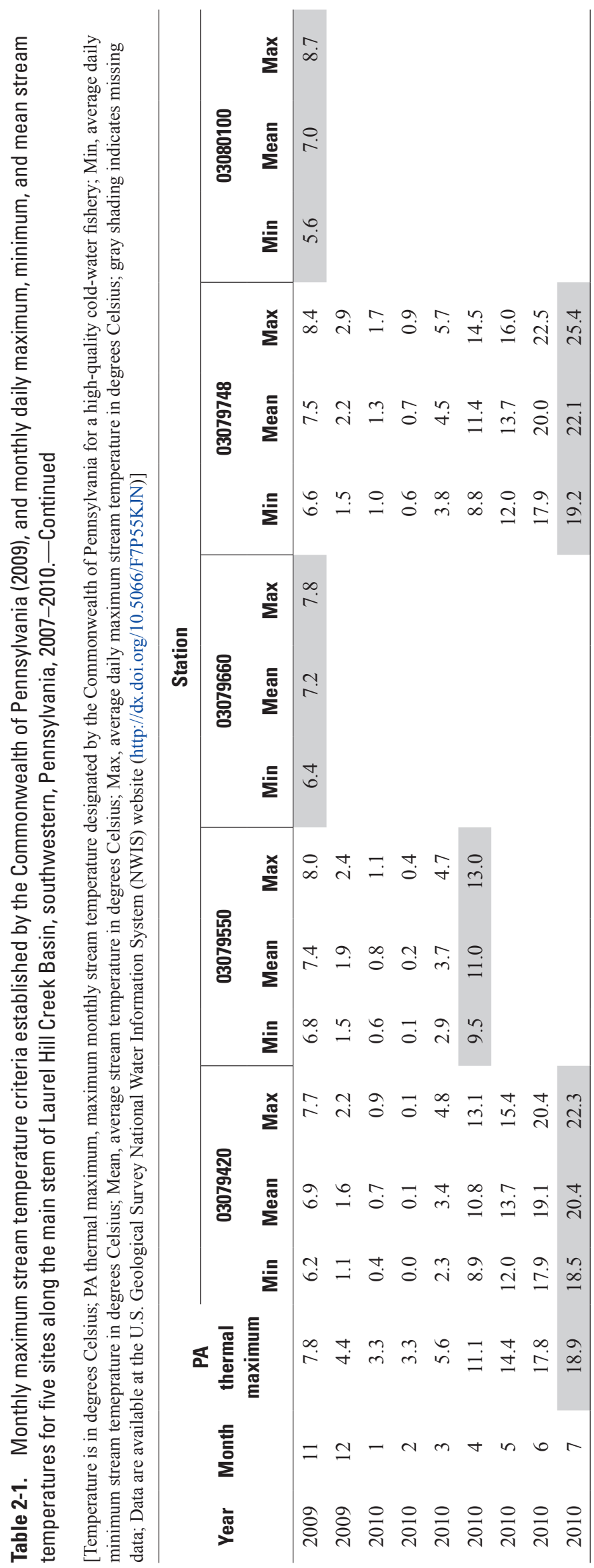


Table 3-1. Daily mean streamflow values for station 03080000, Laurel Hill Creek at Ursina, Pennsylvania, July 17, 2007, through July 8,2010 .

[Data are available at the U.S. Geological Survey National Water Information System (NWIS) website (http://dx.doi.org/10.5066/F7P55KJN)]

\begin{tabular}{|c|c|c|c|c|c|}
\hline Date & $\begin{array}{c}\text { Daily mean } \\
\text { streamflow, } \\
\text { cubic feet per } \\
\text { second }\end{array}$ & Date & $\begin{array}{c}\text { Daily mean } \\
\text { streamflow, } \\
\text { cubic feet per } \\
\text { second }\end{array}$ & Date & $\begin{array}{l}\text { Daily mean } \\
\text { streamflow, } \\
\text { cubic feet per } \\
\text { second }\end{array}$ \\
\hline $7 / 17 / 2007$ & 24 & $8 / 26 / 2007$ & 184 & $10 / 5 / 2007$ & 13 \\
\hline $7 / 18 / 2007$ & 16 & $8 / 27 / 2007$ & 134 & $10 / 6 / 2007$ & 13 \\
\hline $7 / 19 / 2007$ & 20 & $8 / 28 / 2007$ & 99 & $10 / 7 / 2007$ & 12 \\
\hline $7 / 20 / 2007$ & 71 & $8 / 29 / 2007$ & 82 & $10 / 8 / 2007$ & 12 \\
\hline $7 / 21 / 2007$ & 49 & $8 / 30 / 2007$ & 69 & $10 / 9 / 2007$ & 12 \\
\hline $7 / 22 / 2007$ & 29 & $8 / 31 / 2007$ & 60 & $10 / 10 / 2007$ & 14 \\
\hline $7 / 23 / 2007$ & 21 & $9 / 1 / 2007$ & 49 & $10 / 11 / 2007$ & 14 \\
\hline $7 / 24 / 2007$ & 16 & $9 / 2 / 2007$ & 38 & $10 / 12 / 2007$ & 20 \\
\hline $7 / 25 / 2007$ & 14 & $9 / 3 / 2007$ & 33 & $10 / 13 / 2007$ & 23 \\
\hline $7 / 26 / 2007$ & 14 & $9 / 4 / 2007$ & 30 & $10 / 14 / 2007$ & 19 \\
\hline $7 / 27 / 2007$ & 21 & $9 / 5 / 2007$ & 28 & $10 / 15 / 2007$ & 16 \\
\hline $7 / 28 / 2007$ & 21 & $9 / 6 / 2007$ & 26 & $10 / 16 / 2007$ & 15 \\
\hline $7 / 29 / 2007$ & 17 & 9/7/2007 & 23 & $10 / 17 / 2007$ & 15 \\
\hline $7 / 30 / 2007$ & 13 & $9 / 8 / 2007$ & 20 & $10 / 18 / 2007$ & 16 \\
\hline $7 / 31 / 2007$ & 11 & $9 / 9 / 2007$ & 19 & $10 / 19 / 2007$ & 16 \\
\hline $8 / 1 / 2007$ & 9 & $9 / 10 / 2007$ & 23 & $10 / 20 / 2007$ & 18 \\
\hline $8 / 2 / 2007$ & 6 & $9 / 11 / 2007$ & 60 & $10 / 21 / 2007$ & 20 \\
\hline $8 / 3 / 2007$ & 4 & $9 / 12 / 2007$ & 101 & $10 / 22 / 2007$ & 18 \\
\hline $8 / 4 / 2007$ & 3 & $9 / 13 / 2007$ & 48 & $10 / 23 / 2007$ & 17 \\
\hline $8 / 5 / 2007$ & 5 & $9 / 14 / 2007$ & 29 & $10 / 24 / 2007$ & 39 \\
\hline $8 / 6 / 2007$ & 32 & $9 / 15 / 2007$ & 26 & $10 / 25 / 2007$ & 101 \\
\hline $8 / 7 / 2007$ & 67 & $9 / 16 / 2007$ & 23 & $10 / 26 / 2007$ & 73 \\
\hline 8/8/2007 & 49 & $9 / 17 / 2007$ & 20 & $10 / 27 / 2007$ & 68 \\
\hline $8 / 9 / 2007$ & 82 & $9 / 18 / 2007$ & 17 & $10 / 28 / 2007$ & 69 \\
\hline $8 / 10 / 2007$ & 357 & $9 / 19 / 2007$ & 15 & $10 / 29 / 2007$ & 48 \\
\hline $8 / 11 / 2007$ & 178 & $9 / 20 / 2007$ & 15 & $10 / 30 / 2007$ & 35 \\
\hline $8 / 12 / 2007$ & 90 & $9 / 21 / 2007$ & 13 & $10 / 31 / 2007$ & 30 \\
\hline $8 / 13 / 2007$ & 59 & $9 / 22 / 2007$ & 13 & $11 / 1 / 2007$ & 29 \\
\hline $8 / 14 / 2007$ & 39 & $9 / 23 / 2007$ & 13 & $11 / 2 / 2007$ & 32 \\
\hline $8 / 15 / 2007$ & 30 & $9 / 24 / 2007$ & 12 & $11 / 3 / 2007$ & 36 \\
\hline $8 / 16 / 2007$ & 40 & $9 / 25 / 2007$ & 11 & $11 / 4 / 2007$ & 35 \\
\hline $8 / 17 / 2007$ & 60 & $9 / 26 / 2007$ & 10 & $11 / 5 / 2007$ & 35 \\
\hline $8 / 18 / 2007$ & 36 & $9 / 27 / 2007$ & 58 & $11 / 6 / 2007$ & 58 \\
\hline $8 / 19 / 2007$ & 26 & $9 / 28 / 2007$ & 61 & $11 / 7 / 2007$ & 66 \\
\hline $8 / 20 / 2007$ & 147 & $9 / 29 / 2007$ & 31 & $11 / 8 / 2007$ & 57 \\
\hline $8 / 21 / 2007$ & 1730 & 9/30/2007 & 22 & $11 / 9 / 2007$ & 57 \\
\hline $8 / 22 / 2007$ & 1230 & $10 / 1 / 2007$ & 18 & $11 / 10 / 2007$ & 46 \\
\hline $8 / 23 / 2007$ & 657 & $10 / 2 / 2007$ & 15 & $11 / 11 / 2007$ & 33 \\
\hline $8 / 24 / 2007$ & 357 & $10 / 3 / 2007$ & 13 & $11 / 12 / 2007$ & 101 \\
\hline $8 / 25 / 2007$ & 240 & $10 / 4 / 2007$ & 13 & $11 / 13 / 2007$ & 158 \\
\hline
\end{tabular}


Table 3-1. Daily mean streamflow values for station 03080000, Laurel Hill Creek at Ursina, Pennsylvania, July 17, 2007, through July 8, 2010.-Continued

[Data are available at the U.S. Geological Survey National Water Information System (NWIS) website (http://dx.doi.org/10.5066/F7P55KJN)]

\begin{tabular}{|c|c|c|c|c|c|}
\hline Date & $\begin{array}{l}\text { Daily mean } \\
\text { streamflow, } \\
\text { cubic feet per } \\
\text { second }\end{array}$ & Date & $\begin{array}{l}\text { Daily mean } \\
\text { streamflow, } \\
\text { cubic feet per } \\
\text { second }\end{array}$ & Date & $\begin{array}{l}\text { Daily mean } \\
\text { streamflow, } \\
\text { cubic feet per } \\
\text { second }\end{array}$ \\
\hline $11 / 14 / 2007$ & 217 & $12 / 25 / 2007$ & 616 & $2 / 4 / 2008$ & 394 \\
\hline $11 / 15 / 2007$ & 852 & $12 / 26 / 2007$ & 436 & $2 / 5 / 2008$ & 1770 \\
\hline $11 / 16 / 2007$ & 562 & $12 / 27 / 2007$ & 359 & $2 / 6 / 2008$ & 3220 \\
\hline $11 / 17 / 2007$ & 315 & $12 / 28 / 2007$ & 326 & $2 / 7 / 2008$ & 2330 \\
\hline $11 / 18 / 2007$ & 246 & $12 / 29 / 2007$ & 541 & $2 / 8 / 2008$ & 1100 \\
\hline $11 / 19 / 2007$ & 205 & $12 / 30 / 2007$ & 469 & 2/9/2008 & 687 \\
\hline $11 / 20 / 2007$ & 183 & $12 / 31 / 2007$ & 378 & $2 / 10 / 2008$ & 531 \\
\hline $11 / 21 / 2007$ & 171 & $1 / 1 / 2008$ & 335 & $2 / 11 / 2008$ & 396 \\
\hline $11 / 22 / 2007$ & 151 & $1 / 2 / 2008$ & 302 & $2 / 12 / 2008$ & 345 \\
\hline $11 / 23 / 2007$ & 142 & $1 / 3 / 2008$ & 271 & $2 / 13 / 2008$ & 326 \\
\hline $11 / 24 / 2007$ & 119 & $1 / 4 / 2008$ & 221 & $2 / 14 / 2008$ & 276 \\
\hline $11 / 25 / 2007$ & 107 & $1 / 5 / 2008$ & 239 & $2 / 15 / 2008$ & 263 \\
\hline $11 / 26 / 2007$ & 169 & $1 / 6 / 2008$ & 493 & $2 / 16 / 2008$ & 196 \\
\hline $11 / 27 / 2007$ & 964 & $1 / 7 / 2008$ & 663 & $2 / 17 / 2008$ & 199 \\
\hline $11 / 28 / 2007$ & 572 & $1 / 8 / 2008$ & 492 & $2 / 18 / 2008$ & 473 \\
\hline $11 / 29 / 2007$ & 368 & $1 / 9 / 2008$ & 415 & $2 / 19 / 2008$ & 465 \\
\hline $11 / 30 / 2007$ & 279 & $1 / 10 / 2008$ & 347 & $2 / 20 / 2008$ & 345 \\
\hline $12 / 1 / 2007$ & 224 & $1 / 11 / 2008$ & 997 & $2 / 21 / 2008$ & 308 \\
\hline $12 / 2 / 2007$ & 241 & $1 / 12 / 2008$ & 963 & $2 / 22 / 2008$ & 287 \\
\hline $12 / 3 / 2007$ & 1260 & $1 / 13 / 2008$ & 599 & $2 / 23 / 2008$ & 294 \\
\hline $12 / 4 / 2007$ & 756 & $1 / 14 / 2008$ & 474 & $2 / 24 / 2008$ & 252 \\
\hline $12 / 5 / 2007$ & 468 & $1 / 15 / 2008$ & 379 & $2 / 25 / 2008$ & 245 \\
\hline $12 / 6 / 2007$ & 364 & $1 / 16 / 2008$ & 315 & $2 / 26 / 2008$ & 265 \\
\hline $12 / 7 / 2007$ & 333 & $1 / 17 / 2008$ & 276 & $2 / 27 / 2008$ & 436 \\
\hline $12 / 8 / 2007$ & 308 & $1 / 18 / 2008$ & 261 & $2 / 28 / 2008$ & 332 \\
\hline $12 / 9 / 2007$ & 1060 & $1 / 19 / 2008$ & 230 & $2 / 29 / 2008$ & 283 \\
\hline $12 / 10 / 2007$ & 2370 & $1 / 20 / 2008$ & 196 & $3 / 1 / 2008$ & 286 \\
\hline $12 / 11 / 2007$ & 1400 & $1 / 21 / 2008$ & 136 & $3 / 2 / 2008$ & 265 \\
\hline $12 / 12 / 2007$ & 889 & $1 / 22 / 2008$ & 205 & $3 / 3 / 2008$ & 270 \\
\hline $12 / 13 / 2007$ & 2180 & $1 / 23 / 2008$ & 231 & $3 / 4 / 2008$ & 878 \\
\hline $12 / 14 / 2007$ & 2330 & $1 / 24 / 2008$ & 226 & $3 / 5 / 2008$ & 2540 \\
\hline $12 / 15 / 2007$ & 1050 & $1 / 25 / 2008$ & 185 & $3 / 6 / 2008$ & 1260 \\
\hline $12 / 16 / 2007$ & 875 & $1 / 26 / 2008$ & 221 & $3 / 7 / 2008$ & 832 \\
\hline $12 / 17 / 2007$ & 614 & $1 / 27 / 2008$ & 171 & $3 / 8 / 2008$ & 911 \\
\hline $12 / 18 / 2007$ & 428 & $1 / 28 / 2008$ & 161 & $3 / 9 / 2008$ & 751 \\
\hline $12 / 19 / 2007$ & 351 & $1 / 29 / 2008$ & 176 & $3 / 10 / 2008$ & 539 \\
\hline $12 / 20 / 2007$ & 298 & $1 / 30 / 2008$ & 1180 & $3 / 11 / 2008$ & 484 \\
\hline $12 / 21 / 2007$ & 260 & $1 / 31 / 2008$ & 831 & $3 / 12 / 2008$ & 442 \\
\hline $12 / 22 / 2007$ & 231 & $2 / 1 / 2008$ & 529 & $3 / 13 / 2008$ & 384 \\
\hline $12 / 23 / 2007$ & 645 & $2 / 2 / 2008$ & 507 & $3 / 14 / 2008$ & 406 \\
\hline $12 / 24 / 2007$ & 1200 & $2 / 3 / 2008$ & 386 & $3 / 15 / 2008$ & 658 \\
\hline
\end{tabular}


Table 3-1. Daily mean streamflow values for station 03080000, Laurel Hill Creek at Ursina, Pennsylvania, July 17, 2007, through July 8, 2010.-Continued

[Data are available at the U.S. Geological Survey National Water Information System (NWIS) website (http://dx.doi.org/10.5066/F7P55KJN)]

\begin{tabular}{|c|c|c|c|c|c|}
\hline Date & $\begin{array}{l}\text { Daily mean } \\
\text { streamflow, } \\
\text { cubic feet per } \\
\text { second }\end{array}$ & Date & $\begin{array}{l}\text { Daily mean } \\
\text { streamflow, } \\
\text { cubic feet per } \\
\text { second }\end{array}$ & Date & $\begin{array}{l}\text { Daily mean } \\
\text { streamflow, } \\
\text { cubic feet per } \\
\text { second }\end{array}$ \\
\hline $3 / 16 / 2008$ & 536 & $4 / 26 / 2008$ & 223 & $6 / 6 / 2008$ & 305 \\
\hline $3 / 17 / 2008$ & 409 & $4 / 27 / 2008$ & 230 & $6 / 7 / 2008$ & 227 \\
\hline $3 / 18 / 2008$ & 416 & $4 / 28 / 2008$ & 385 & $6 / 8 / 2008$ & 188 \\
\hline $3 / 19 / 2008$ & 792 & 4/29/2008 & 468 & $6 / 9 / 2008$ & 151 \\
\hline $3 / 20 / 2008$ & 1030 & 4/30/2008 & 352 & $6 / 10 / 2008$ & 131 \\
\hline $3 / 21 / 2008$ & 729 & $5 / 1 / 2008$ & 309 & $6 / 11 / 2008$ & 169 \\
\hline $3 / 22 / 2008$ & 554 & $5 / 2 / 2008$ & 274 & $6 / 12 / 2008$ & 116 \\
\hline $3 / 23 / 2008$ & 443 & $5 / 3 / 2008$ & 249 & $6 / 13 / 2008$ & 97 \\
\hline $3 / 24 / 2008$ & 362 & $5 / 4 / 2008$ & 248 & $6 / 14 / 2008$ & 117 \\
\hline $3 / 25 / 2008$ & 304 & $5 / 5 / 2008$ & 201 & $6 / 15 / 2008$ & 252 \\
\hline $3 / 26 / 2008$ & 258 & $5 / 6 / 2008$ & 176 & $6 / 16 / 2008$ & 143 \\
\hline $3 / 27 / 2008$ & 244 & $5 / 7 / 2008$ & 153 & $6 / 17 / 2008$ & 116 \\
\hline $3 / 28 / 2008$ & 290 & $5 / 8 / 2008$ & 190 & $6 / 18 / 2008$ & 101 \\
\hline $3 / 29 / 2008$ & 267 & $5 / 9 / 2008$ & 420 & $6 / 19 / 2008$ & 125 \\
\hline $3 / 30 / 2008$ & 227 & $5 / 10 / 2008$ & 1610 & $6 / 20 / 2008$ & 93 \\
\hline $3 / 31 / 2008$ & 218 & $5 / 11 / 2008$ & 1280 & $6 / 21 / 2008$ & 82 \\
\hline $4 / 1 / 2008$ & 217 & $5 / 12 / 2008$ & 1270 & $6 / 22 / 2008$ & 85 \\
\hline $4 / 2 / 2008$ & 206 & $5 / 13 / 2008$ & 904 & $6 / 23 / 2008$ & 74 \\
\hline $4 / 3 / 2008$ & 179 & $5 / 14 / 2008$ & 606 & $6 / 24 / 2008$ & 66 \\
\hline $4 / 4 / 2008$ & 191 & $5 / 15 / 2008$ & 556 & $6 / 25 / 2008$ & 55 \\
\hline $4 / 5 / 2008$ & 310 & $5 / 16 / 2008$ & 925 & $6 / 26 / 2008$ & 49 \\
\hline $4 / 6 / 2008$ & 267 & $5 / 17 / 2008$ & 942 & $6 / 27 / 2008$ & 73 \\
\hline $4 / 7 / 2008$ & 236 & $5 / 18 / 2008$ & 1460 & $6 / 28 / 2008$ & 72 \\
\hline $4 / 8 / 2008$ & 216 & $5 / 19 / 2008$ & 1250 & $6 / 29 / 2008$ & 66 \\
\hline 4/9/2008 & 206 & $5 / 20 / 2008$ & 956 & $6 / 30 / 2008$ & 108 \\
\hline $4 / 10 / 2008$ & 191 & $5 / 21 / 2008$ & 870 & $7 / 1 / 2008$ & 113 \\
\hline $4 / 11 / 2008$ & 181 & $5 / 22 / 2008$ & 650 & $7 / 2 / 2008$ & 92 \\
\hline $4 / 12 / 2008$ & 258 & $5 / 23 / 2008$ & 475 & $7 / 3 / 2008$ & 74 \\
\hline $4 / 13 / 2008$ & 235 & $5 / 24 / 2008$ & 373 & $7 / 4 / 2008$ & 131 \\
\hline $4 / 14 / 2008$ & 230 & $5 / 25 / 2008$ & 306 & $7 / 5 / 2008$ & 168 \\
\hline $4 / 15 / 2008$ & 206 & $5 / 26 / 2008$ & 253 & $7 / 6 / 2008$ & 117 \\
\hline $4 / 16 / 2008$ & 191 & $5 / 27 / 2008$ & 229 & $7 / 7 / 2008$ & 101 \\
\hline $4 / 17 / 2008$ & 182 & $5 / 28 / 2008$ & 245 & $7 / 8 / 2008$ & 101 \\
\hline $4 / 18 / 2008$ & 170 & $5 / 29 / 2008$ & 182 & 7/9/2008 & 101 \\
\hline $4 / 19 / 2008$ & 156 & $5 / 30 / 2008$ & 147 & $7 / 10 / 2008$ & 137 \\
\hline $4 / 20 / 2008$ & 400 & $5 / 31 / 2008$ & 320 & $7 / 11 / 2008$ & 98 \\
\hline $4 / 21 / 2008$ & 472 & $6 / 1 / 2008$ & 339 & $7 / 12 / 2008$ & 81 \\
\hline $4 / 22 / 2008$ & 368 & $6 / 2 / 2008$ & 214 & $7 / 13 / 2008$ & 69 \\
\hline $4 / 23 / 2008$ & 318 & $6 / 3 / 2008$ & 175 & $7 / 14 / 2008$ & 64 \\
\hline $4 / 24 / 2008$ & 278 & $6 / 4 / 2008$ & 205 & $7 / 15 / 2008$ & 49 \\
\hline $4 / 25 / 2008$ & 245 & $6 / 5 / 2008$ & 410 & $7 / 16 / 2008$ & 42 \\
\hline
\end{tabular}


Table 3-1 Daily mean streamflow values for station 03080000, Laurel Hill Creek at Ursina, Pennsylvania, July 17, 2007, through July 8, 2010.-Continued

[Data are available at the U.S. Geological Survey National Water Information System (NWIS) website (http://dx.doi.org/10.5066/F7P55KJN)]

\begin{tabular}{|c|c|c|c|c|c|}
\hline Date & $\begin{array}{l}\text { Daily mean } \\
\text { streamflow, } \\
\text { cubic feet per } \\
\text { second }\end{array}$ & Date & $\begin{array}{l}\text { Daily mean } \\
\text { streamflow, } \\
\text { cubic feet per } \\
\text { second }\end{array}$ & Date & $\begin{array}{l}\text { Daily mean } \\
\text { streamflow, } \\
\text { cubic feet per } \\
\text { second }\end{array}$ \\
\hline $7 / 17 / 2008$ & 38 & $8 / 27 / 2008$ & 12 & $10 / 7 / 2008$ & 16 \\
\hline $7 / 18 / 2008$ & 33 & $8 / 28 / 2008$ & 31 & $10 / 8 / 2008$ & 15 \\
\hline 7/19/2008 & 30 & $8 / 29 / 2008$ & 72 & $10 / 9 / 2008$ & 17 \\
\hline $7 / 20 / 2008$ & 27 & $8 / 30 / 2008$ & 45 & $10 / 10 / 2008$ & 20 \\
\hline $7 / 21 / 2008$ & 33 & $8 / 31 / 2008$ & 36 & $10 / 11 / 2008$ & 18 \\
\hline $7 / 22 / 2008$ & 107 & $9 / 1 / 2008$ & 23 & $10 / 12 / 2008$ & 15 \\
\hline $7 / 23 / 2008$ & 508 & $9 / 2 / 2008$ & 18 & $10 / 13 / 2008$ & 12 \\
\hline $7 / 24 / 2008$ & 373 & $9 / 3 / 2008$ & 14 & $10 / 14 / 2008$ & 11 \\
\hline $7 / 25 / 2008$ & 179 & $9 / 4 / 2008$ & 11 & $10 / 15 / 2008$ & 12 \\
\hline $7 / 26 / 2008$ & 114 & $9 / 5 / 2008$ & 10 & $10 / 16 / 2008$ & 13 \\
\hline $7 / 27 / 2008$ & 94 & $9 / 6 / 2008$ & 14 & $10 / 17 / 2008$ & 15 \\
\hline $7 / 28 / 2008$ & 77 & $9 / 7 / 2008$ & 14 & $10 / 18 / 2008$ & 16 \\
\hline $7 / 29 / 2008$ & 61 & 9/8/2008 & 13 & $10 / 19 / 2008$ & 16 \\
\hline $7 / 30 / 2008$ & 56 & 9/9/2008 & 332 & $10 / 20 / 2008$ & 16 \\
\hline $7 / 31 / 2008$ & 272 & $9 / 10 / 2008$ & 198 & $10 / 21 / 2008$ & 15 \\
\hline $8 / 1 / 2008$ & 192 & $9 / 11 / 2008$ & 83 & $10 / 22 / 2008$ & 16 \\
\hline $8 / 2 / 2008$ & 480 & $9 / 12 / 2008$ & 80 & $10 / 23 / 2008$ & 17 \\
\hline $8 / 3 / 2008$ & 289 & $9 / 13 / 2008$ & 275 & $10 / 24 / 2008$ & 16 \\
\hline $8 / 4 / 2008$ & 184 & $9 / 14 / 2008$ & 176 & $10 / 25 / 2008$ & 23 \\
\hline $8 / 5 / 2008$ & 130 & $9 / 15 / 2008$ & 106 & $10 / 26 / 2008$ & 52 \\
\hline $8 / 6 / 2008$ & 130 & $9 / 16 / 2008$ & 91 & $10 / 27 / 2008$ & 41 \\
\hline $8 / 7 / 2008$ & 100 & $9 / 17 / 2008$ & 67 & $10 / 28 / 2008$ & 33 \\
\hline 8/8/2008 & 83 & $9 / 18 / 2008$ & 47 & $10 / 29 / 2008$ & 38 \\
\hline $8 / 9 / 2008$ & 72 & $9 / 19 / 2008$ & 39 & $10 / 30 / 2008$ & 44 \\
\hline $8 / 10 / 2008$ & 58 & $9 / 20 / 2008$ & 35 & $10 / 31 / 2008$ & 41 \\
\hline $8 / 11 / 2008$ & 51 & $9 / 21 / 2008$ & 32 & $11 / 1 / 2008$ & 41 \\
\hline $8 / 12 / 2008$ & 46 & $9 / 22 / 2008$ & 29 & $11 / 2 / 2008$ & 42 \\
\hline $8 / 13 / 2008$ & 41 & $9 / 23 / 2008$ & 26 & $11 / 3 / 2008$ & 37 \\
\hline $8 / 14 / 2008$ & 37 & $9 / 24 / 2008$ & 23 & $11 / 4 / 2008$ & 33 \\
\hline $8 / 15 / 2008$ & 34 & $9 / 25 / 2008$ & 23 & $11 / 5 / 2008$ & 35 \\
\hline $8 / 16 / 2008$ & 32 & $9 / 26 / 2008$ & 21 & $11 / 6 / 2008$ & 42 \\
\hline $8 / 17 / 2008$ & 27 & $9 / 27 / 2008$ & 25 & $11 / 7 / 2008$ & 42 \\
\hline $8 / 18 / 2008$ & 26 & $9 / 28 / 2008$ & 34 & $11 / 8 / 2008$ & 41 \\
\hline $8 / 19 / 2008$ & 24 & $9 / 29 / 2008$ & 31 & $11 / 9 / 2008$ & 41 \\
\hline $8 / 20 / 2008$ & 20 & $9 / 30 / 2008$ & 26 & $11 / 10 / 2008$ & 41 \\
\hline $8 / 21 / 2008$ & 18 & $10 / 1 / 2008$ & 23 & $11 / 11 / 2008$ & 39 \\
\hline $8 / 22 / 2008$ & 16 & $10 / 2 / 2008$ & 21 & $11 / 12 / 2008$ & 39 \\
\hline $8 / 23 / 2008$ & 15 & $10 / 3 / 2008$ & 22 & $11 / 13 / 2008$ & 48 \\
\hline $8 / 24 / 2008$ & 14 & $10 / 4 / 2008$ & 21 & $11 / 14 / 2008$ & 61 \\
\hline $8 / 25 / 2008$ & 13 & $10 / 5 / 2008$ & 19 & $11 / 15 / 2008$ & 60 \\
\hline $8 / 26 / 2008$ & 12 & $10 / 6 / 2008$ & 18 & $11 / 16 / 2008$ & 90 \\
\hline
\end{tabular}


Table 3-1 Daily mean streamflow values for station 03080000, Laurel Hill Creek at Ursina, Pennsylvania, July 17, 2007, through July 8, 2010.-Continued

[Data are available at the U.S. Geological Survey National Water Information System (NWIS) website (http://dx.doi.org/10.5066/F7P55KJN)]

\begin{tabular}{|c|c|c|c|c|c|}
\hline Date & $\begin{array}{l}\text { Daily mean } \\
\text { streamflow, } \\
\text { cubic feet per } \\
\text { second }\end{array}$ & Date & $\begin{array}{l}\text { Daily mean } \\
\text { streamflow, } \\
\text { cubic feet per } \\
\text { second }\end{array}$ & Date & $\begin{array}{l}\text { Daily mean } \\
\text { streamflow, } \\
\text { cubic feet per } \\
\text { second }\end{array}$ \\
\hline $11 / 17 / 2008$ & 77 & $12 / 28 / 2008$ & 1130 & $2 / 7 / 2009$ & 257 \\
\hline $11 / 18 / 2008$ & 78 & $12 / 29 / 2008$ & 673 & $2 / 8 / 2009$ & 1850 \\
\hline $11 / 19 / 2008$ & 78 & $12 / 30 / 2008$ & 474 & 2/9/2009 & 1690 \\
\hline $11 / 20 / 2008$ & 78 & $12 / 31 / 2008$ & 382 & $2 / 10 / 2009$ & 1320 \\
\hline $11 / 21 / 2008$ & 81 & $1 / 1 / 2009$ & 325 & $2 / 11 / 2009$ & 2390 \\
\hline $11 / 22 / 2008$ & 109 & $1 / 2 / 2009$ & 296 & $2 / 12 / 2009$ & 2140 \\
\hline $11 / 23 / 2008$ & 162 & $1 / 3 / 2009$ & 233 & 2/13/2009 & 1170 \\
\hline $11 / 24 / 2008$ & 161 & $1 / 4 / 2009$ & 223 & $2 / 14 / 2009$ & 664 \\
\hline $11 / 25 / 2008$ & 428 & $1 / 5 / 2009$ & 352 & $2 / 15 / 2009$ & 468 \\
\hline $11 / 26 / 2008$ & 343 & $1 / 6 / 2009$ & 326 & $2 / 16 / 2009$ & 365 \\
\hline $11 / 27 / 2008$ & 235 & $1 / 7 / 2009$ & 1010 & $2 / 17 / 2009$ & 307 \\
\hline $11 / 28 / 2008$ & 201 & $1 / 8 / 2009$ & 1260 & $2 / 18 / 2009$ & 286 \\
\hline $11 / 29 / 2008$ & 176 & $1 / 9 / 2009$ & 627 & $2 / 19 / 2009$ & 390 \\
\hline $11 / 30 / 2008$ & 182 & $1 / 10 / 2009$ & 456 & $2 / 20 / 2009$ & 331 \\
\hline $12 / 1 / 2008$ & 375 & $1 / 11 / 2009$ & 471 & $2 / 21 / 2009$ & 312 \\
\hline $12 / 2 / 2008$ & 303 & $1 / 12 / 2009$ & 374 & $2 / 22 / 2009$ & 253 \\
\hline $12 / 3 / 2008$ & 230 & $1 / 13 / 2009$ & 319 & $2 / 23 / 2009$ & 229 \\
\hline $12 / 4 / 2008$ & 236 & $1 / 14 / 2009$ & 285 & $2 / 24 / 2009$ & 217 \\
\hline $12 / 5 / 2008$ & 313 & $1 / 15 / 2009$ & 240 & $2 / 25 / 2009$ & 215 \\
\hline $12 / 6 / 2008$ & 263 & $1 / 16 / 2009$ & 183 & $2 / 26 / 2009$ & 199 \\
\hline $12 / 7 / 2008$ & 224 & $1 / 17 / 2009$ & 149 & 2/27/2009 & 237 \\
\hline $12 / 8 / 2008$ & 195 & $1 / 18 / 2009$ & 206 & $2 / 28 / 2009$ & 358 \\
\hline $12 / 9 / 2008$ & 177 & $1 / 19 / 2009$ & 213 & $3 / 1 / 2009$ & 297 \\
\hline $12 / 10 / 2008$ & 741 & $1 / 20 / 2009$ & 226 & $3 / 2 / 2009$ & 256 \\
\hline $12 / 11 / 2008$ & 1270 & $1 / 21 / 2009$ & 190 & $3 / 3 / 2009$ & 234 \\
\hline $12 / 12 / 2008$ & 1870 & $1 / 22 / 2009$ & 190 & $3 / 4 / 2009$ & 225 \\
\hline $12 / 13 / 2008$ & 916 & $1 / 23 / 2009$ & 278 & $3 / 5 / 2009$ & 232 \\
\hline $12 / 14 / 2008$ & 548 & $1 / 24 / 2009$ & 190 & $3 / 6 / 2009$ & 184 \\
\hline $12 / 15 / 2008$ & 471 & $1 / 25 / 2009$ & 345 & $3 / 7 / 2009$ & 185 \\
\hline $12 / 16 / 2008$ & 785 & $1 / 26 / 2009$ & 309 & $3 / 8 / 2009$ & 184 \\
\hline $12 / 17 / 2008$ & 1120 & $1 / 27 / 2009$ & 249 & $3 / 9 / 2009$ & 184 \\
\hline $12 / 18 / 2008$ & 1090 & $1 / 28 / 2009$ & 292 & $3 / 10 / 2009$ & 154 \\
\hline $12 / 19 / 2008$ & 2600 & $1 / 29 / 2009$ & 528 & $3 / 11 / 2009$ & 134 \\
\hline $12 / 20 / 2008$ & 3350 & $1 / 30 / 2009$ & 326 & $3 / 12 / 2009$ & 125 \\
\hline $12 / 21 / 2008$ & 1300 & $1 / 31 / 2009$ & 286 & $3 / 13 / 2009$ & 111 \\
\hline $12 / 22 / 2008$ & 660 & $2 / 1 / 2009$ & 304 & $3 / 14 / 2009$ & 105 \\
\hline $12 / 23 / 2008$ & 458 & $2 / 2 / 2009$ & 251 & $3 / 15 / 2009$ & 101 \\
\hline $12 / 24 / 2008$ & 1340 & $2 / 3 / 2009$ & 244 & $3 / 16 / 2009$ & 98 \\
\hline $12 / 25 / 2008$ & 2840 & $2 / 4 / 2009$ & 258 & $3 / 17 / 2009$ & 109 \\
\hline $12 / 26 / 2008$ & 1300 & $2 / 5 / 2009$ & 200 & $3 / 18 / 2009$ & 103 \\
\hline $12 / 27 / 2008$ & 1860 & 2/6/2009 & 312 & $3 / 19 / 2009$ & 97 \\
\hline
\end{tabular}


Table 3-1 Daily mean streamflow values for station 03080000, Laurel Hill Creek at Ursina, Pennsylvania, July 17, 2007, through July 8, 2010.-Continued

[Data are available at the U.S. Geological Survey National Water Information System (NWIS) website (http://dx.doi.org/10.5066/F7P55KJN)]

\begin{tabular}{|c|c|c|c|c|c|}
\hline Date & $\begin{array}{l}\text { Daily mean } \\
\text { streamflow, } \\
\text { cubic feet per } \\
\text { second }\end{array}$ & Date & $\begin{array}{c}\text { Daily mean } \\
\text { streamflow, } \\
\text { cubic feet per } \\
\text { second }\end{array}$ & Date & $\begin{array}{l}\text { Daily mean } \\
\text { streamflow, } \\
\text { cubic feet per } \\
\text { second }\end{array}$ \\
\hline $3 / 20 / 2009$ & 92 & $4 / 30 / 2009$ & 206 & $6 / 10 / 2009$ & 125 \\
\hline $3 / 21 / 2009$ & 83 & $5 / 1 / 2009$ & 323 & $6 / 11 / 2009$ & 109 \\
\hline $3 / 22 / 2009$ & 80 & $5 / 2 / 2009$ & 1110 & $6 / 12 / 2009$ & 157 \\
\hline $3 / 23 / 2009$ & 77 & $5 / 3 / 2009$ & 769 & $6 / 13 / 2009$ & 122 \\
\hline $3 / 24 / 2009$ & 71 & $5 / 4 / 2009$ & 2290 & $6 / 14 / 2009$ & 93 \\
\hline $3 / 25 / 2009$ & 68 & $5 / 5 / 2009$ & 2010 & $6 / 15 / 2009$ & 79 \\
\hline $3 / 26 / 2009$ & 181 & $5 / 6 / 2009$ & 1100 & $6 / 16 / 2009$ & 68 \\
\hline $3 / 27 / 2009$ & 424 & $5 / 7 / 2009$ & 1390 & $6 / 17 / 2009$ & 89 \\
\hline $3 / 28 / 2009$ & 335 & 5/8/2009 & 856 & $6 / 18 / 2009$ & 2340 \\
\hline 3/29/2009 & 329 & 5/9/2009 & 587 & $6 / 19 / 2009$ & 751 \\
\hline $3 / 30 / 2009$ & 327 & $5 / 10 / 2009$ & 425 & $6 / 20 / 2009$ & 515 \\
\hline $3 / 31 / 2009$ & 284 & $5 / 11 / 2009$ & 360 & $6 / 21 / 2009$ & 1000 \\
\hline 4/1/2009 & 268 & $5 / 12 / 2009$ & 386 & $6 / 22 / 2009$ & 787 \\
\hline $4 / 2 / 2009$ & 259 & $5 / 13 / 2009$ & 297 & $6 / 23 / 2009$ & 380 \\
\hline $4 / 3 / 2009$ & 378 & $5 / 14 / 2009$ & 254 & $6 / 24 / 2009$ & 260 \\
\hline $4 / 4 / 2009$ & 770 & $5 / 15 / 2009$ & 225 & $6 / 25 / 2009$ & 201 \\
\hline $4 / 5 / 2009$ & 472 & $5 / 16 / 2009$ & 199 & $6 / 26 / 2009$ & 163 \\
\hline $4 / 6 / 2009$ & 400 & $5 / 17 / 2009$ & 212 & $6 / 27 / 2009$ & 133 \\
\hline 4/7/2009 & 365 & $5 / 18 / 2009$ & 183 & $6 / 28 / 2009$ & 107 \\
\hline 4/8/2009 & 327 & $5 / 19 / 2009$ & 150 & $6 / 29 / 2009$ & 95 \\
\hline 4/9/2009 & 326 & $5 / 20 / 2009$ & 130 & $6 / 30 / 2009$ & 91 \\
\hline $4 / 10 / 2009$ & 284 & $5 / 21 / 2009$ & 112 & $7 / 1 / 2009$ & 97 \\
\hline $4 / 11 / 2009$ & 323 & $5 / 22 / 2009$ & 101 & $7 / 2 / 2009$ & 189 \\
\hline $4 / 12 / 2009$ & 318 & $5 / 23 / 2009$ & 91 & $7 / 3 / 2009$ & 147 \\
\hline $4 / 13 / 2009$ & 273 & $5 / 24 / 2009$ & 83 & $7 / 4 / 2009$ & 123 \\
\hline $4 / 14 / 2009$ & 268 & $5 / 25 / 2009$ & 94 & $7 / 5 / 2009$ & 94 \\
\hline $4 / 15 / 2009$ & 301 & $5 / 26 / 2009$ & 184 & $7 / 6 / 2009$ & 76 \\
\hline $4 / 16 / 2009$ & 325 & $5 / 27 / 2009$ & 172 & 7/7/2009 & 66 \\
\hline $4 / 17 / 2009$ & 276 & $5 / 28 / 2009$ & 244 & $7 / 8 / 2009$ & 57 \\
\hline $4 / 18 / 2009$ & 251 & $5 / 29 / 2009$ & 246 & 7/9/2009 & 51 \\
\hline $4 / 19 / 2009$ & 233 & $5 / 30 / 2009$ & 222 & $7 / 10 / 2009$ & 45 \\
\hline $4 / 20 / 2009$ & 297 & $5 / 31 / 2009$ & 165 & $7 / 11 / 2009$ & 43 \\
\hline $4 / 21 / 2009$ & 486 & $6 / 1 / 2009$ & 131 & $7 / 12 / 2009$ & 44 \\
\hline $4 / 22 / 2009$ & 450 & $6 / 2 / 2009$ & 159 & $7 / 13 / 2009$ & 42 \\
\hline $4 / 23 / 2009$ & 502 & $6 / 3 / 2009$ & 206 & $7 / 14 / 2009$ & 37 \\
\hline $4 / 24 / 2009$ & 414 & 6/4/2009 & 201 & $7 / 15 / 2009$ & 31 \\
\hline $4 / 25 / 2009$ & 359 & $6 / 5 / 2009$ & 246 & $7 / 16 / 2009$ & 28 \\
\hline $4 / 26 / 2009$ & 309 & 6/6/2009 & 218 & $7 / 17 / 2009$ & 31 \\
\hline $4 / 27 / 2009$ & 266 & 6/7/2009 & 170 & $7 / 18 / 2009$ & 38 \\
\hline $4 / 28 / 2009$ & 231 & 6/8/2009 & 135 & $7 / 19 / 2009$ & 34 \\
\hline $4 / 29 / 2009$ & 223 & 6/9/2009 & 125 & $7 / 20 / 2009$ & 28 \\
\hline
\end{tabular}


Table 3-1 Daily mean streamflow values for station 03080000, Laurel Hill Creek at Ursina, Pennsylvania, July 17, 2007, through July 8, 2010.-Continued

[Data are available at the U.S. Geological Survey National Water Information System (NWIS) website (http://dx.doi.org/10.5066/F7P55KJN)]

\begin{tabular}{|c|c|c|c|c|c|}
\hline Date & $\begin{array}{l}\text { Daily mean } \\
\text { streamflow, } \\
\text { cubic feet per } \\
\text { second }\end{array}$ & Date & $\begin{array}{l}\text { Daily mean } \\
\text { streamflow, } \\
\text { cubic feet per } \\
\text { second }\end{array}$ & Date & $\begin{array}{l}\text { Daily mean } \\
\text { streamflow, } \\
\text { cubic feet per } \\
\text { second }\end{array}$ \\
\hline $7 / 21 / 2009$ & 49 & $8 / 31 / 2009$ & 46 & 10/11/2009 & 539 \\
\hline $7 / 22 / 2009$ & 62 & $9 / 1 / 2009$ & 34 & $10 / 12 / 2009$ & 276 \\
\hline $7 / 23 / 2009$ & 57 & $9 / 2 / 2009$ & 25 & $10 / 13 / 2009$ & 195 \\
\hline $7 / 24 / 2009$ & 46 & $9 / 3 / 2009$ & 21 & $10 / 14 / 2009$ & 153 \\
\hline $7 / 25 / 2009$ & 36 & $9 / 4 / 2009$ & 20 & $10 / 15 / 2009$ & 194 \\
\hline $7 / 26 / 2009$ & 29 & 9/5/2009 & 18 & 10/16/2009 & 440 \\
\hline $7 / 27 / 2009$ & 26 & $9 / 6 / 2009$ & 17 & $10 / 17 / 2009$ & 334 \\
\hline 7/28/2009 & 25 & $9 / 7 / 2009$ & 16 & $10 / 18 / 2009$ & 280 \\
\hline 7/29/2009 & 32 & $9 / 8 / 2009$ & 16 & $10 / 19 / 2009$ & 240 \\
\hline 7/30/2009 & 107 & $9 / 9 / 2009$ & 16 & $10 / 20 / 2009$ & 198 \\
\hline $7 / 31 / 2009$ & 100 & $9 / 10 / 2009$ & 15 & $10 / 21 / 2009$ & 163 \\
\hline $8 / 1 / 2009$ & 111 & $9 / 11 / 2009$ & 14 & 10/22/2009 & 141 \\
\hline $8 / 2 / 2009$ & 82 & $9 / 12 / 2009$ & 13 & $10 / 23 / 2009$ & 130 \\
\hline $8 / 3 / 2009$ & 76 & $9 / 13 / 2009$ & 13 & $10 / 24 / 2009$ & 469 \\
\hline 8/4/2009 & 55 & $9 / 14 / 2009$ & 13 & $10 / 25 / 2009$ & 446 \\
\hline $8 / 5 / 2009$ & 44 & $9 / 15 / 2009$ & 12 & $10 / 26 / 2009$ & 340 \\
\hline $8 / 6 / 2009$ & 41 & $9 / 16 / 2009$ & 12 & 10/27/2009 & 321 \\
\hline $8 / 7 / 2009$ & 38 & $9 / 17 / 2009$ & 11 & $10 / 28 / 2009$ & 426 \\
\hline $8 / 8 / 2009$ & 31 & $9 / 18 / 2009$ & 11 & $10 / 29 / 2009$ & 381 \\
\hline 8/9/2009 & 28 & 9/19/2009 & 10 & $10 / 30 / 2009$ & 346 \\
\hline 8/10/2009 & 26 & $9 / 20 / 2009$ & 10 & $10 / 31 / 2009$ & 316 \\
\hline $8 / 11 / 2009$ & 26 & $9 / 21 / 2009$ & 10 & $11 / 1 / 2009$ & 290 \\
\hline $8 / 12 / 2009$ & 37 & $9 / 22 / 2009$ & 10 & $11 / 2 / 2009$ & 252 \\
\hline 8/13/2009 & 50 & $9 / 23 / 2009$ & 10 & $11 / 3 / 2009$ & 225 \\
\hline 8/14/2009 & 38 & $9 / 24 / 2009$ & 14 & $11 / 4 / 2009$ & 202 \\
\hline $8 / 15 / 2009$ & 28 & $9 / 25 / 2009$ & 14 & $11 / 5 / 2009$ & 183 \\
\hline 8/16/2009 & 23 & $9 / 26 / 2009$ & 17 & $11 / 6 / 2009$ & 160 \\
\hline 8/17/2009 & 21 & $9 / 27 / 2009$ & 68 & $11 / 7 / 2009$ & 129 \\
\hline 8/18/2009 & 21 & $9 / 28 / 2009$ & 66 & $11 / 8 / 2009$ & 119 \\
\hline 8/19/2009 & 23 & $9 / 29 / 2009$ & 45 & $11 / 9 / 2009$ & 109 \\
\hline 8/20/2009 & 21 & $9 / 30 / 2009$ & 114 & $11 / 10 / 2009$ & 76 \\
\hline $8 / 21 / 2009$ & 29 & $10 / 1 / 2009$ & 112 & $11 / 11 / 2009$ & 72 \\
\hline $8 / 22 / 2009$ & 36 & $10 / 2 / 2009$ & 64 & $11 / 12 / 2009$ & 66 \\
\hline $8 / 23 / 2009$ & 25 & $10 / 3 / 2009$ & 61 & $11 / 13 / 2009$ & 64 \\
\hline $8 / 24 / 2009$ & 20 & $10 / 4 / 2009$ & 55 & $11 / 14 / 2009$ & 62 \\
\hline $8 / 25 / 2009$ & 18 & $10 / 5 / 2009$ & 40 & $11 / 15 / 2009$ & 60 \\
\hline $8 / 26 / 2009$ & 16 & $10 / 6 / 2009$ & 34 & $11 / 16 / 2009$ & 58 \\
\hline $8 / 27 / 2009$ & 15 & $10 / 7 / 2009$ & 32 & $11 / 17 / 2009$ & 54 \\
\hline $8 / 28 / 2009$ & 14 & $10 / 8 / 2009$ & 31 & $11 / 18 / 2009$ & 52 \\
\hline $8 / 29 / 2009$ & 184 & $10 / 9 / 2009$ & 237 & $11 / 19 / 2009$ & 57 \\
\hline $8 / 30 / 2009$ & 93 & $10 / 10 / 2009$ & 1210 & $11 / 20 / 2009$ & 90 \\
\hline
\end{tabular}


Table 3-1 Daily mean streamflow values for station 03080000, Laurel Hill Creek at Ursina, Pennsylvania, July 17, 2007, through July 8, 2010.-Continued

[Data are available at the U.S. Geological Survey National Water Information System (NWIS) website (http://dx.doi.org/10.5066/F7P55KJN)]

\begin{tabular}{|c|c|c|c|c|c|}
\hline Date & $\begin{array}{l}\text { Daily mean } \\
\text { streamflow, } \\
\text { cubic feet per } \\
\text { second }\end{array}$ & Date & $\begin{array}{c}\text { Daily mean } \\
\text { streamflow, } \\
\text { cubic feet per } \\
\text { second }\end{array}$ & Date & $\begin{array}{c}\text { Daily mean } \\
\text { streamflow, } \\
\text { cubic feet per } \\
\text { second }\end{array}$ \\
\hline $11 / 21 / 2009$ & 90 & $1 / 1 / 2010$ & 211 & $2 / 11 / 2010$ & 157 \\
\hline $11 / 22 / 2009$ & 77 & $1 / 2 / 2010$ & 178 & $2 / 12 / 2010$ & 154 \\
\hline $11 / 23 / 2009$ & 69 & $1 / 3 / 2010$ & 158 & $2 / 13 / 2010$ & 180 \\
\hline $11 / 24 / 2009$ & 68 & $1 / 4 / 2010$ & 190 & $2 / 14 / 2010$ & 132 \\
\hline $11 / 25 / 2009$ & 70 & $1 / 5 / 2010$ & 194 & $2 / 15 / 2010$ & 188 \\
\hline $11 / 26 / 2009$ & 67 & $1 / 6 / 2010$ & 174 & $2 / 16 / 2010$ & 227 \\
\hline $11 / 27 / 2009$ & 74 & 1/7/2010 & 192 & $2 / 17 / 2010$ & 199 \\
\hline $11 / 28 / 2009$ & 83 & $1 / 8 / 2010$ & 178 & $2 / 18 / 2010$ & 171 \\
\hline $11 / 29 / 2009$ & 80 & $1 / 9 / 2010$ & 181 & $2 / 19 / 2010$ & 151 \\
\hline $11 / 30 / 2009$ & 149 & $1 / 10 / 2010$ & 215 & $2 / 20 / 2010$ & 188 \\
\hline $12 / 1 / 2009$ & 222 & $1 / 11 / 2010$ & 273 & $2 / 21 / 2010$ & 141 \\
\hline $12 / 2 / 2009$ & 187 & $1 / 12 / 2010$ & 324 & $2 / 22 / 2010$ & 119 \\
\hline $12 / 3 / 2009$ & 382 & $1 / 13 / 2010$ & 304 & $2 / 23 / 2010$ & 174 \\
\hline $12 / 4 / 2009$ & 354 & $1 / 14 / 2010$ & 305 & $2 / 24 / 2010$ & 172 \\
\hline $12 / 5 / 2009$ & 294 & $1 / 15 / 2010$ & 234 & $2 / 25 / 2010$ & 183 \\
\hline $12 / 6 / 2009$ & 252 & $1 / 16 / 2010$ & 213 & $2 / 26 / 2010$ & 130 \\
\hline $12 / 7 / 2009$ & 216 & $1 / 17 / 2010$ & 535 & $2 / 27 / 2010$ & 140 \\
\hline $12 / 8 / 2009$ & 197 & $1 / 18 / 2010$ & 839 & $2 / 28 / 2010$ & 140 \\
\hline $12 / 9 / 2009$ & 745 & $1 / 19 / 2010$ & 652 & $3 / 1 / 2010$ & 131 \\
\hline $12 / 10 / 2009$ & 911 & $1 / 20 / 2010$ & 484 & $3 / 2 / 2010$ & 122 \\
\hline $12 / 11 / 2009$ & 449 & $1 / 21 / 2010$ & 384 & $3 / 3 / 2010$ & 118 \\
\hline $12 / 12 / 2009$ & 403 & $1 / 22 / 2010$ & 360 & $3 / 4 / 2010$ & 166 \\
\hline $12 / 13 / 2009$ & 310 & $1 / 23 / 2010$ & 335 & $3 / 5 / 2010$ & 254 \\
\hline $12 / 14 / 2009$ & 599 & $1 / 24 / 2010$ & 355 & $3 / 6 / 2010$ & 249 \\
\hline $12 / 15 / 2009$ & 694 & $1 / 25 / 2010$ & 4280 & $3 / 7 / 2010$ & 255 \\
\hline $12 / 16 / 2009$ & 627 & $1 / 26 / 2010$ & 2780 & $3 / 8 / 2010$ & 263 \\
\hline $12 / 17 / 2009$ & 425 & $1 / 27 / 2010$ & 1120 & $3 / 9 / 2010$ & 294 \\
\hline $12 / 18 / 2009$ & 343 & $1 / 28 / 2010$ & 676 & $3 / 10 / 2010$ & 404 \\
\hline $12 / 19 / 2009$ & 318 & $1 / 29 / 2010$ & 488 & $3 / 11 / 2010$ & 894 \\
\hline $12 / 20 / 2009$ & 288 & $1 / 30 / 2010$ & 400 & $3 / 12 / 2010$ & 2710 \\
\hline $12 / 21 / 2009$ & 252 & $1 / 31 / 2010$ & 335 & $3 / 13 / 2010$ & 4100 \\
\hline $12 / 22 / 2009$ & 206 & $2 / 1 / 2010$ & 305 & $3 / 14 / 2010$ & 3740 \\
\hline $12 / 23 / 2009$ & 188 & $2 / 2 / 2010$ & 251 & $3 / 15 / 2010$ & 2180 \\
\hline $12 / 24 / 2009$ & 172 & $2 / 3 / 2010$ & 214 & $3 / 16 / 2010$ & 1810 \\
\hline $12 / 25 / 2009$ & 229 & $2 / 4 / 2010$ & 192 & $3 / 17 / 2010$ & 1730 \\
\hline $12 / 26 / 2009$ & 253 & $2 / 5 / 2010$ & 174 & $3 / 18 / 2010$ & 1510 \\
\hline $12 / 27 / 2009$ & 277 & $2 / 6 / 2010$ & 182 & $3 / 19 / 2010$ & 1360 \\
\hline $12 / 28 / 2009$ & 241 & $2 / 7 / 2010$ & 274 & $3 / 20 / 2010$ & 1400 \\
\hline $12 / 29 / 2009$ & 211 & $2 / 8 / 2010$ & 218 & $3 / 21 / 2010$ & 1370 \\
\hline $12 / 30 / 2009$ & 185 & $2 / 9 / 2010$ & 209 & $3 / 22 / 2010$ & 1430 \\
\hline $12 / 31 / 2009$ & 227 & $2 / 10 / 2010$ & 163 & $3 / 23 / 2010$ & 1800 \\
\hline
\end{tabular}


Table 3-1. Daily mean streamflow values for station 03080000, Laurel Hill Creek at Ursina, Pennsylvania, July 17, 2007, through July 8, 2010.-Continued

[Data are available at the U.S. Geological Survey National Water Information System (NWIS) website (http://dx.doi.org/10.5066/F7P55KJN)]

\begin{tabular}{|c|c|c|c|c|c|}
\hline Date & $\begin{array}{c}\text { Daily mean } \\
\text { streamflow, } \\
\text { cubic feet per } \\
\text { second }\end{array}$ & Date & $\begin{array}{c}\text { Daily mean } \\
\text { streamflow, } \\
\text { cubic feet per } \\
\text { second }\end{array}$ & Date & $\begin{array}{c}\text { Daily mean } \\
\text { streamflow, } \\
\text { cubic feet per } \\
\text { second }\end{array}$ \\
\hline $3 / 24 / 2010$ & 1120 & $5 / 4 / 2010$ & 810 & $6 / 14 / 2010$ & 110 \\
\hline $3 / 25 / 2010$ & 783 & $5 / 5 / 2010$ & 489 & $6 / 15 / 2010$ & 122 \\
\hline $3 / 26 / 2010$ & 859 & $5 / 6 / 2010$ & 375 & $6 / 16 / 2010$ & 115 \\
\hline $3 / 27 / 2010$ & 619 & $5 / 7 / 2010$ & 289 & $6 / 17 / 2010$ & 90 \\
\hline $3 / 28 / 2010$ & 545 & $5 / 8 / 2010$ & 297 & $6 / 18 / 2010$ & 73 \\
\hline $3 / 29 / 2010$ & 736 & $5 / 9 / 2010$ & 287 & $6 / 19 / 2010$ & 62 \\
\hline $3 / 30 / 2010$ & 558 & $5 / 10 / 2010$ & 236 & $6 / 20 / 2010$ & 93 \\
\hline $3 / 31 / 2010$ & 453 & $5 / 11 / 2010$ & 262 & $6 / 21 / 2010$ & 71 \\
\hline $4 / 1 / 2010$ & 377 & $5 / 12 / 2010$ & 488 & $6 / 22 / 2010$ & 55 \\
\hline $4 / 2 / 2010$ & 325 & $5 / 13 / 2010$ & 386 & $6 / 23 / 2010$ & 51 \\
\hline $4 / 3 / 2010$ & 283 & $5 / 14 / 2010$ & 323 & $6 / 24 / 2010$ & 49 \\
\hline $4 / 4 / 2010$ & 247 & $5 / 15 / 2010$ & 319 & $6 / 25 / 2010$ & 59 \\
\hline $4 / 5 / 2010$ & 216 & $5 / 16 / 2010$ & 256 & $6 / 26 / 2010$ & 50 \\
\hline $4 / 6 / 2010$ & 197 & $5 / 17 / 2010$ & 407 & $6 / 27 / 2010$ & 41 \\
\hline $4 / 7 / 2010$ & 181 & $5 / 18 / 2010$ & 824 & $6 / 28 / 2010$ & 44 \\
\hline $4 / 8 / 2010$ & 164 & $5 / 19 / 2010$ & 560 & $6 / 29 / 2010$ & 39 \\
\hline $4 / 9 / 2010$ & 175 & $5 / 20 / 2010$ & 491 & $6 / 30 / 2010$ & 34 \\
\hline $4 / 10 / 2010$ & 137 & $5 / 21 / 2010$ & 382 & $7 / 1 / 2010$ & 29 \\
\hline $4 / 11 / 2010$ & 115 & $5 / 22 / 2010$ & 556 & $7 / 2 / 2010$ & 25 \\
\hline $4 / 12 / 2010$ & 106 & $5 / 23 / 2010$ & 1240 & $7 / 3 / 2010$ & 24 \\
\hline $4 / 13 / 2010$ & 100 & $5 / 24 / 2010$ & 687 & $7 / 4 / 2010$ & 23 \\
\hline $4 / 14 / 2010$ & 100 & $5 / 25 / 2010$ & 485 & $7 / 5 / 2010$ & 22 \\
\hline $4 / 15 / 2010$ & 91 & $5 / 26 / 2010$ & 371 & $7 / 6 / 2010$ & 20 \\
\hline $4 / 16 / 2010$ & 94 & $5 / 27 / 2010$ & 289 & $7 / 7 / 2010$ & 20 \\
\hline $4 / 17 / 2010$ & 348 & $5 / 28 / 2010$ & 232 & $7 / 8 / 2010$ & 18 \\
\hline $4 / 18 / 2010$ & 236 & $5 / 29 / 2010$ & 216 & & \\
\hline $4 / 19 / 2010$ & 194 & $5 / 30 / 2010$ & 166 & & \\
\hline $4 / 20 / 2010$ & 168 & $5 / 31 / 2010$ & 134 & & \\
\hline $4 / 21 / 2010$ & 154 & $6 / 1 / 2010$ & 137 & & \\
\hline $4 / 22 / 2010$ & 138 & $6 / 2 / 2010$ & 107 & & \\
\hline $4 / 23 / 2010$ & 120 & $6 / 3 / 2010$ & 90 & & \\
\hline $4 / 24 / 2010$ & 108 & $6 / 4 / 2010$ & 80 & & \\
\hline $4 / 25 / 2010$ & 136 & $6 / 5 / 2010$ & 95 & & \\
\hline $4 / 26 / 2010$ & 389 & $6 / 6 / 2010$ & 112 & & \\
\hline $4 / 27 / 2010$ & 549 & 6/7/2010 & 84 & & \\
\hline $4 / 28 / 2010$ & 390 & $6 / 8 / 2010$ & 64 & & \\
\hline $4 / 29 / 2010$ & 309 & 6/9/2010 & 139 & & \\
\hline $4 / 30 / 2010$ & 258 & $6 / 10 / 2010$ & 449 & & \\
\hline $5 / 1 / 2010$ & 221 & $6 / 11 / 2010$ & 221 & & \\
\hline $5 / 2 / 2010$ & 222 & $6 / 12 / 2010$ & 141 & & \\
\hline $5 / 3 / 2010$ & 1160 & $6 / 13 / 2010$ & 122 & & \\
\hline
\end{tabular}


Publishing support provided by the U.S. Geological Survey Science Publishing Network, West Trenton Publishing Service Center

For more information concerning the research in this report, contact: Director, Pennsylvania Water Science Center

U.S. Geological Survey

215 Limekiln Road

New Cumberland, Pa. 17070

http://pa.water.usgs.gov/ 


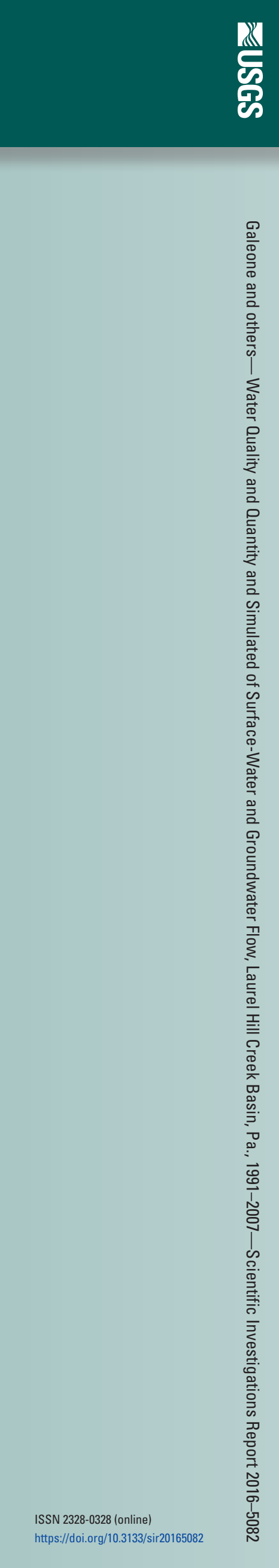

